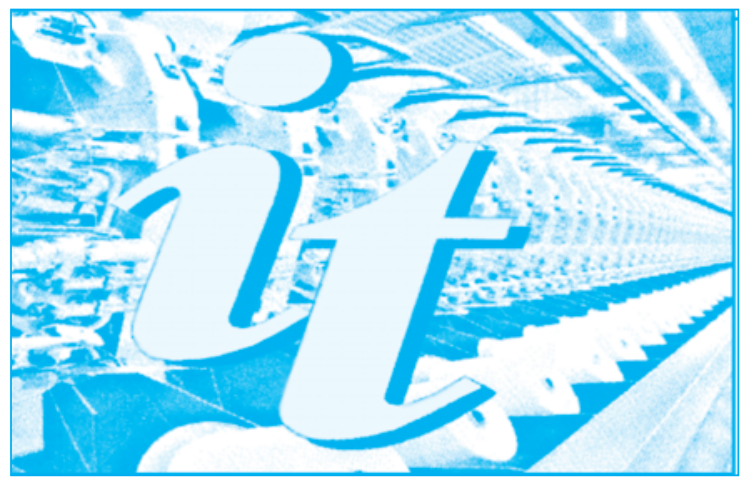

ISI rated journal, included in the ISI Master Journal List of the Institute of Science Information, Philadelphia, USA, starting with vol. 58, no. 1/2007, with impact factor 0.504 and AIS 0.046 in 2018

The journal is indexed by CrossRef, starting with no. 1/2017 having the title DOI: https://doi.org/10.35530/IT.

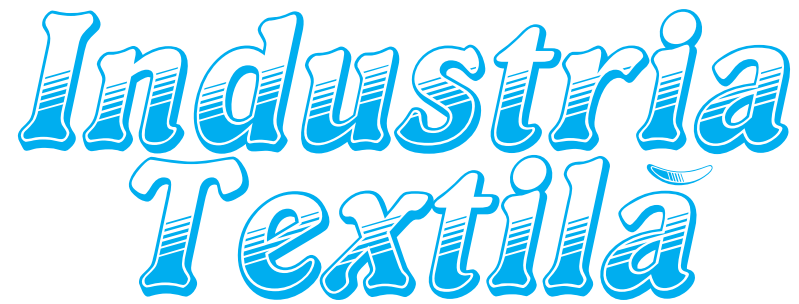

ISSN 1 222-5347

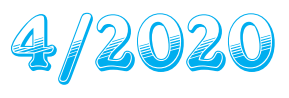

Edited in 6 issues per year, indexed and abstracted in:

Science Citation Index Expanded (SCIE), Materials Science Citation Index ${ }^{\circledR}$, Journal Citation Reports/Science Edition, World Textile Abstracts,

Chemical Abstracts, VINITI, Scopus, Toga FIZ technik ProQuest Central, Crossref

Edited with the Romanian Ministry of Education and Research support

\section{INIDUSTRIA TEXTILA EIDITDRIAL BOARD:}

Dr. Eng. CARMEN GHITULEASA GENERAL MANAGER

National R\&D Institute for Textiles and Leather Bucharest, Romania

Dr. Eng. SABINA OLARU CS II, EDITOR IN CHIEF

National R\&D Institute for Textiles and Leather, Bucharest, Romania

Dr. Eng. EMILIA VISILEANU CS I, HONORIFIC EDITOR

National R\&D Institute for Textiles and Leather Bucharest, Romania Prof. XIANYI ZENG

Ecole Nationale Superieure des Arts et Industries Textiles (ENSAIT), France

Prof. Dr. Eng. LUIS ALMEIDA

University of Minho, Portugal

Prof. Dr. STJEPANOVIČ ZORAN

University of Maribor, Faculty of Mechanical

Engineering, Department of Textile Materials

and Design, Maribor, Slovenia

Lec. ALEXANDRA DE RAEVE

University College Ghent, Fashion, Textile

and Wood Technology Department, Belgium Prof. LUBOS HES

$P h D, M S c, B S c$, Department of Textile Evaluation, Technical University of Liberec, Czech Republic Prof. Dr. Eng. ERHAN ONER

Marmara University, Turkey

Prof. Dr. S. MUGE YUKSELOGLU Marmara University, Turkey Dr. MAZARI ADNAN ASSISTANT PROFESSOR Department of Textile Clothing, Faculty of Textile Engineering, Technical University of Liberec Czech Republic Dr. AMINODDIN HAJ

$P h D, M S c, B S c$, Textile Chemistry and Fiber Science ASSISTANT PROFESSOR

Textile Engineering Department Yazd University, Yazd, Iran

Prof. Dr. Eng. CARMEN LOGHIN PRO-RECTOR

Faculty of Industrial Design and Business Management, Technical University "Gh. Asachi", laşi, Romania

Associate Prof. Dr. Eng. MARIANA URSACHE Faculty of Industria

Business Management, Technical University "Gh. Asachi", laşi, Romania

Prof. Dr. GELU ONOSE

$$
\text { CSI }
$$

"Carol Davila" University of Medicine and Pharmacy, Bucharest, Romania Prof. Dr. DOINA I. POPESCU The Bucharest University of Economic Studies, Bucharest, Romania

Prof. Dr. MARGARETA STELEA FLORESCU

The Bucharest University of Economic Studies, Bucharest, Romania
LAURA CHIRILA, LUDMILA OTILIA CINTEZA, MARIA TANASE,

DIANA ELENA RADULESCU, DENISA MARIA RADULESCU,

IOANA RODICA STANCULESCU

Hybrid materials based on $\mathrm{ZnO}$ and $\mathrm{SiO}_{2}$ nanoparticles as hydrophobic coatings for textiles

$297-301$

MINE AKGUN, GIZEM KARAKAN GUNAYDIN, AYÇA GÜRARDA

ERHAN KENAN CEVEN

Investigation of the comfort properties of traditional woven fabrics with

different structural parameters

AURA SPINU, VLADIMIR CARDEI, VALERIU AVRAMESCU, IOANA ANDONE,

AURELIA ROMILA, AURELIAN ANGHELESCU, MIHAIL TIBERIU AVRAMESCU,

ANA-MARIA BUMBEA, ELENA VALENTINA IONESCU, VLAD CIOBANU,

CRISTINA DAIA, GELU ONOSE

Narrative designed proposals of mechanical or electro-mechanical optimization

to the current wheelchairs used by people with severe locomotion restraints

ADRIAN SALISTEAN, CARMEN MIHAI

Textile wing fabric for emergency response UAS

BOLAR SHAKILA, PINTO PRAKASH, IQBAL THONSE HAWALDAR,

CRISTI SPULBAR, RAMONA BIRAU

The holiday effects in stock returns: a challenge for the textile and clothing

industry of India

RALUCA MARIA AILENI, SILVIA ALBICI, LAURA CHIRIAC,

IRINA-MARIANA SĂNDULACHE

Multivariate regression analysis of the $3 \mathrm{D}$ composites with electroconductive

properties for sensors

$302-308$

MELIE TADESSE, EMIL-CONSTANTIN LOGHIN, VINCENT NIERSTRASZ,

MARIA-CARMEN LOGHIN

Quality inspection and prediction of the comfort of fabrics finished

with functional polymers

NAVEED TAYYAB, RASHDI YASEEN SAYED, REHMAN FAISAL, WEI WANG

AWAN ASHRAF JAVEED, ABBAS MUDASSAR, FRAZ AHMAD, AWAIS MUHAMMAD

Dyeing and colour fastness of natural dye from Citrus aurantium

on Lyocell fabric

NICOLETA ANDREEA NEACŞU, SIMONA BĂLĂŞESCU, MARIUS BĂLĂŞESCU,

CARMEN ELENA ANTON

Social responsibility in the textile industry in Romania

NIKOLA V. ĆURČIĆ, ALEKSANDAR GRUBOR, NIKOLA RADIVOJEVIĆ,

ZORAN D. SIMONOVIC

Examining causality between market share and competitiveness: case study textile industry

AHMET ÖZBEK

Online customized T-shirt design and evaluation of online websites

for customization

TUBA TOPRAK, MINE AKGUN, PERVIN ANIS

Effects of environmentally friendly degumming methods on some surface properties, physical performances and dyeing behaviour of silk fabrics

CORINA SPOREA, MARGARETA STELA FLORESCU, DUMITRU FERECHIDE, IOAN CRISTESCU

Comparative assessment of dexterity tests results using two internationally recognized scales in patients with cerebral palsy, users of medical textiles

ANGELOVA A. RADOSTINA, MIROSLAV KYOSOV, PETER STANKOV

Computational modelling of the heat transfer through two-layer woven

structure ensembles

$321-326$

$327-333$

ZOUHOUR CHOURABI, AMEL BABAY, FAOUZI KHEDHER,

MORCHED CHEIKHROUHOU

A new objective function for the assembly line balancing optimization

in terms of workers' global competence

Web of Science Journal Category: Materials Science, Textiles

Aknowledged in Romania, in the Engineering sciences domain, by the National Council of the Scientific Research from the Higher Education (CNCSIS), in group $A$ 


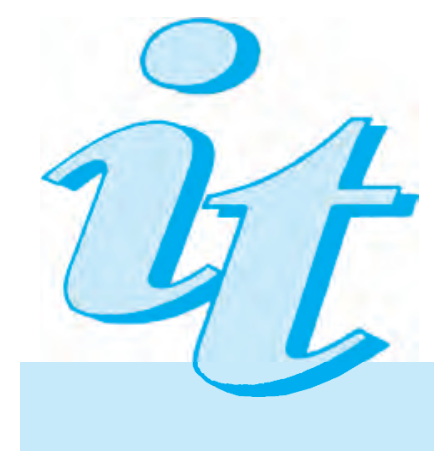

Scientific reviewers for the papers published in this number:

Dr. Hammad Cheema, University of Mississippi, Chemistry and Bio-Chemistry Department, USA

Prof. Jose Ivan Medeiros, Universidade Federal do Rio Grande do Norte, Brazil

Assoc. Prof. Dr. Jatin Trivedi, Amity University Mumbai, Faculty of Finance, India

PhD M. G. Krishnamurthy, Jawaharlal Nehru National College of Engineering, Department of Management Studies \& Research, India

Prof. Dr. İbrahim Uçgül, Süleyman Demirel University, Faculty of Textile Engineer, Turkey

Prof. Kalaoglu Fatma, Istanbul Technical University, Department of Textile Engineering, Turkey

Prof. Zdravko Krivokapic, University of Montenegro, Montenegro

Prof. Jelena Sakovic - Jovanovic, University of Montenegro, Montenegro

Prof. Dr. Polona Dobnik Dubrovski, University of Maribor, Faculty of Mechanical Engineering, Textile Materials and Design Department, Slovenia

Prof. Dr. Behçet Becerir, Uludağ University, Textile Engineering Department, Turkey

Prof. Dr. Ayca Gurarda, Uludağ University, Textile Engineering Department, Turkey

Lect. PhD Ramona Birau, Constantin Brancusi University, Romania

Prof. Dr. Liviu Lazăr, University of Oradea, Faculty of Medicine and Pharmacy, Romania

Conf. Dr. Camelia Ciobotaru, Ovidius University of Constanta, Faculty of Medicine, Romania

Dr. eng. Emilia Visileanu, National Research and Development Institute for Textiles and Leahter, Romania

Dr. Assad Farooq, University of Agriculture, Department of Fiber \& Textile Technology, Pakistan

Dr. Tariq Iqbal Khan, Government Postgraduate College Jaranwala, Department of Economics, Pakistan

Dr. Erkan Kadir Simsek, Akdeniz University, Turkey

Dr. Muhammad Mohsin, University of Engineering and Technology, Pakistan

Assist. Prof. M. Babar Ramzan, National Textile University, Pakistan

Research Assist. Türkoğlu Gizem Ceylan, Dokuz Eylul University Faculty of Engineering

Department of Textile Engineering, Turkey

\begin{tabular}{c} 
EDITORIAL STAFF \\
General Manager: Dr. Eng. Carmen Ghițuleasa \\
Editor-in-chief: Dr. Eng. Sabina Olaru \\
Onorific editor: Dr. Eng. Emilia Visileanu \\
Graphic designer: Florin Prisecaru \\
Translator: Cătălina Costea \\
Site administrator: Constantin Dragomir \\
e-mail: industriatextila@incdtp.ro \\
\hline
\end{tabular}

INDUSTRIA TEXTILA journal, edited by INCDTP BUCHAREST, implements and respects Regulation 2016/679/EU on the protection of individuals with regard to the processing of personal data and on the free movement of such data ("RGPD"). For information, please visit the Personal Data Processing Protection Policy link or e-mail to DPO rpd@incdtp.ro

Journal edited in colaboration with Editura AGIR, 118 Calea Victoriei, sector 1, Bucharest, tel./fax: 021-316.89.92; 021-316.89.93; e-mail: editura@agir.ro,www.edituraagir.ro 


\section{Hybrid materials based on $\mathrm{ZnO}$ and $\mathrm{SiO}_{2}$ nanoparticles as hydrophobic coatings for textiles}

DOI: $10.35530 / 1 T .071 .04 .1814$

LAURA CHIRILA
LUDMILA OTILIA CINTEZA
MARIA TANASE
DIANA ELENA RADULESCU

DENISA MARIA RADULESCU

IOANA RODICA STANCULESCU

\section{ABSTRACT - REZUMAT}

Hybrid materials based on $\mathrm{ZnO}$ and $\mathrm{SiO}_{2}$ nanoparticles as hydrophobic coatings for textiles

This study presents a strategy to obtain textile materials with hydrophobic/oleophobic effect by applying hybrid coatings based on a mixture of flower-like $\mathrm{ZnO}$ nanoparticles and organically modified $\mathrm{SiO}_{2}$ nanoparticles (ORMOSIL). The obtained dispersions based on both types of nanoparticles are stable, with unimodal distribution of smaller quasi spherical shape and average size of $158 \mathrm{~nm}$ for $\mathrm{SiO}_{2}$ nanoparticles and respectively, with bimodal distribution with a broad distribution of particle size and average size of $144 \mathrm{~nm}$ and $435 \mathrm{~nm}$ for ZnO flower-like nanoparticles. The $\mathrm{ZnO} / \mathrm{SiO}_{2} \mathrm{NPs}$ based dispersions were then applied on $100 \%$ cotton fabrics on a laboratory scale by padding method in two successive phases. The functionalized cotton fabrics were evaluated in terms of surface morphology changes, whiteness degree and water and oils repellent properties. The developed textile materials exhibited a low wetting capacity, with high values of water absorption time (>15 minutes) and a water-repellent degree of 75 (AATCC photographic scale) and 2.5 respectively (ISO scale) showing an acceptable hydrophobic effect. The functionalization treatment based on mixture of $\mathrm{ZnO} / \mathrm{SiO}_{2}$ nanoparticles led to obtaining an efficient cotton substrate for the rejection and protection against the oily substances which exhibit an oil repellency degree of 6 . Also, the functionalization treatments did not significantly change the surface morphology of the fibres, suggesting that the bulk properties of the cotton fibres remained undamaged.

Keywords: flower-like $\mathrm{ZnO}$ nanoparticles, $\mathrm{SiO}_{2}$ nanoparticles, cotton fabric, water repellency, oil repellency

\section{Materiale hibride pe bază de nanoparticule de $\mathrm{ZnO}$ și $\mathrm{SiO}_{2}$ ca acoperiri de hidrofobizare pentru materiale textile}

Acest studiu prezintă o strategie de obținere a materialelor textile cu efect hidrofob/oleofob prin aplicarea unor acoperiri hibride bazate pe un amestec de nanoparticule $\mathrm{ZnO}$ flower-like și nanoparticule $\mathrm{SiO}_{2}$ modificate organic (ORMOSIL). Dispersiile obținute pe baza ambelor tipuri pe nanoparticule, sunt stabile, cu o distribuție unimodală de particule de $\mathrm{SiO}_{2}$ cu forma cvazisferică mai mică, cu dimensiunea medie de $158 \mathrm{~nm}$ și, respectiv, cu o distribuție bimodală, cu un domeniu larg al mărimii particulelor, cu dimensiuni medii cuprinse între $144 \mathrm{~nm}$ și $435 \mathrm{~nm}$ pentru nanoparticulele de ZnO flower-like. Dispersiile pe bază de $\mathrm{ZnO} / \mathrm{SiO}_{2} \mathrm{NPs}$ au fost apoi aplicate pe țesături din $100 \%$ bumbac la scară de laborator, prin metoda fulardării în două faze succesive. Țesăturile din bumbac funcționalizate au fost evaluate în ceea ce privește modificările morfologiei de suprafață, gradul de alb și capacitatea de respingere a apei și a uleiurilor. Materialele textile dezvoltate au prezentat o capacitate de umectare scăzută, cu valori ridicate ale timpului de absorbție a apei (>15 minute) și o capacitate de respingere a apei de 75 (scara fotografică AATCC) și respectiv 2,5 (scara ISO), prezentând un efect hidrofob acceptabil. Tratamentul de funcționalizare bazat pe amestecul de nanoparticule de $\mathrm{ZnO} / \mathrm{SiO}_{2}$ a dus la obținerea unui substrat eficient din bumbac pentru respingerea și protecția împotriva substanțelor uleioase, care manifestă un grad de respingere a uleiului de 6. De asemenea, tratamentele de funcționalizare nu au modificat în mod semnificativ morfologia de suprafață a fibrelor, ceea ce sugerează că proprietățile în vrac ale fibrelor de bumbac au rămas nedeteriorate.

Cuvinte cheie: nanoparticule de $\mathrm{ZnO}$ flower-like, nanoparticule de $\mathrm{SiO}_{2}$, țesătură din bumbac, capacitatea de respingere a apei, capacitatea de respingere a uleiurilor

\section{INTRODUCTION}

Textile materials present a wide applicability in numerous domains, through the introduction of superhydrophobicity on fibrous structures. This finishing process represents an ideal candidate for oil/water mixture separation and protection equipment development, but also to manufacture antibacterial and self-cleaning products. In this regard, functional coatings aim to improve the properties and performance of textile substrates as well as to introduce novel functions [1]. Based on previous research studies, for an enhanced protection of textile materials from water and other solvents, modified nanoparticles have been used to obtain hydrophobic and oleophobic properties achieving long-lasting resistance [2-3]. Zinc oxide $(\mathrm{ZnO})$ has already been considered an outstanding chemical compound for textile functionalization due to its unique chemical and physical properties, environmental friendliness, biocompatibility, and low price. According to literature, $\mathrm{ZnO}$ nanoparticles 
( $\mathrm{ZnO} N \mathrm{NP}$ ) were used in combination with hydrophobic or oleophobic precursors to provide multifunctional properties, such as antimicrobial, UV-protective, and hydrophobic/oleophobic properties on textile surfaces [4]. To improve these properties, the entrapment of the air in the space between the rough features has been promoted by creating certain micro/nano-roughness structures. The increase in surface roughness can be achieved by the development of micro/nanostructures such as micro/ nanoparticles, micro/nano flower-like structures, nanowires and nanorods [5]. In this regard, flowerlike ZnO NPs promote an increased hydrophobicity and oleophobicity compared to the nanorod morphology [6].

Furthermore, silica nanoparticles $\left(\mathrm{SiO}_{2} \mathrm{NPs}\right)$ represent another type of nanoparticles applied for the development of hydrophobic/oleophobic surfaces. Therefore, by generating functional groups on the surface of $\mathrm{SiO}_{2} \mathrm{NPs}$, these specific properties are improved. The hydroxyl functional groups $(-\mathrm{OH})$ on the surface of silica nanoparticles control nanoparticles growth and hence, act as a proper support material for nanoparticles deposition [7]. Moreover, organically modified silica (ORMOSIL) hydrophobic thin films have shown great potential for the functionalization of textile materials and other supports due to their good mechanical and thermal stability. ORMOSIL materials are commonly preferred due to their unique features, such as flexibility and stability at atmospheric conditions, which cannot be accomplished by organic polymers or glasses. In addition, different changes can be accomplished through the modification/substitution of the organic group on the ORMOSIL, leading to certain improvements regarding the physical and chemical properties of the resulting surfaces (e.g. wettability). The aim of this study was to develop hydrophobic/oleophobic cotton fabrics by applying hybrid materials based on flower-like $\mathrm{ZnO} \mathrm{NPs}$ and organically modified $\mathrm{SiO}_{2}$ NPs (ORMOSIL).

\section{EXPERIMENTAL PART}

\section{Materials}

Zinc nitrate hexahydrate $-\mathrm{Zn}\left(\mathrm{NO}_{3}\right)_{6} \cdot \mathrm{H}_{2} \mathrm{O}$ reagent grade 95\% (Sigma Aldrich Chemie, Germany), sodium hydroxide $(\mathrm{NaOH},>98 \%$, Sigma Aldrich Chemie, Germany), cetyltrymethyl ammonium bromide (CTAB, $>99 \%$, Sigma Aldrich Chemie, Germany) reagent for molecular biology, tetraethoxysilane (TEOS, 98\%, Sigma Aldrich Chemie, Germany), triethoxy(octyl) silane (OTEOS, 97\%, Sigma Aldrich Chemie, Germany), ammonia (33\% solution, Sigma Aldrich Chemie, Germany) were used without further purification or treatment. Double distilled water and ethanol (absolute, Reactivul SA) were employed as solvents. Bleached plain weave $100 \%$ cotton fabric with weight per unit area of $254 \mathrm{~g} / \mathrm{m}^{2}$ was used for the functionalization process.

\section{Synthesis of flower-like ZnO nanoparticles}

ZnO NPs were synthesized using a surfactant free hydrothermal method [8] with some modifications. Briefly, $20 \mathrm{ml}$ of $0.1 \mathrm{M}$ solution of $\mathrm{Zn}$ nitrate hexahydrate $\left(\mathrm{ZnNO}_{3} \cdot 6 \mathrm{H}_{2} \mathrm{O}\right)$ was mixed with $20 \mathrm{ml}$ of $0.6 \mathrm{M}$ solution of $C T A B$, under magnetic stirring, in a $100 \mathrm{ml}$ vial, at $85^{\circ} \mathrm{C}$. To the resulted mixture, a volume of $10 \mathrm{ml}$ of $\mathrm{NaOH}$ solution 0.3 M was added dropwise, under vigorous stirring. The previous clear solution turned milky while the $\mathrm{NaOH}$ solution was added. Further, the dispersion was sealed in a in vial and left for reaction at temperature, under magnetic stirring for $12 \mathrm{~h}$. After the natural cooling at room temperature, the obtained white precipitate was separated by centrifugation, washed three times with distilled water and absolute alcohol. The $\mathrm{ZnO}$ nanopowder was then dried at $105^{\circ} \mathrm{C}$ for $4 \mathrm{~h}$.

\section{Synthesis of organo-modified $\mathrm{SiO}_{2}$ nanoparticles}

The synthesis of $\mathrm{SiO}_{2} \mathrm{NPs}$ was performed by using a procedure modified in our laboratory, based on Stöber method, i.e. hydrolysis and condensation of silane compound in basic catalysis [9]. A volume of $1 \mathrm{ml}$ of $33 \%$ ammonia solution was added to $15 \mathrm{ml}$ of ethanol in a vial and heated at $50^{\circ} \mathrm{C}$. A TEOS solution with 2.25 M concentration was prepared by dissolving silane derivative in ethanol. $2 \mathrm{ml}$ of the above solution was added into the vial in one step, under vigorous magnetic stirring. The formation of $\mathrm{SiO}_{2}$ NPs was proved when the solution became slightly turbid. The temperature and stirring were maintained for $2 \mathrm{~h}$ to allow particles maturation. Then, $1 \mathrm{ml}$ of organo-modified silica reagent OTEOS was added dropwise ( $0.5 \mathrm{M}$ solution in ethanol). The dispersion was left for aging under temperature and stirring for another $2 \mathrm{~h}$ for the formation of the organo-modified nanoparticles. The modified $\mathrm{SiO}_{2} \mathrm{NPs}$ were separated by centrifugation and washed with ethanol to remove the unreacted compounds.

\section{Immobilization of $\mathrm{ZnO}$ and $\mathrm{SiO}_{2}$ NPs on the textile materials}

In order to avoid the aggregation of nanoparticles during the functionalization of the textile materials, the $\mathrm{ZnO}$ and $\mathrm{SiO}_{2}$ dispersions were prepared separately and mixed just before the textile treatment. A dispersion of $2 \% \mathrm{ZnO}$ NPs in distilled water was prepared by mixing the $\mathrm{ZnO}$ nanopowder with water, under magnetic stirring, followed by sonication in a bath for 10 minutes (Branson, 50W). The modified $\mathrm{SiO}_{2}$ NPs were dispersed in a $0.002 \mathrm{M}$ solution of polydimethyl siloxane as hydrophobization polymeric agent.

$\mathrm{ZnO}$ and $\mathrm{SiO}_{2}$ NPs dispersions were deposited separately by padding method on the laboratory padder (ROAKES, UK) in successive phases on the surface of textile materials, in the following conditions: 5 passes of the textile material, 2 barr squeezing pressure, with a wet pick-up rate of $85 \%$. After each impregnation operation, the treated textile materials 
were then subjected on the drying operation at $100^{\circ} \mathrm{C}$ for 3 minutes. The drying process of the impregnated textile materials was carried out on the drying/curing/heat-setting/vaporization unit, model TFO/S 500 $\mathrm{mm}$ (ROACHES, UK). The sequence of the constituent operations of functionalization process are the following: padding with ZnO NPs dispersions $\rightarrow$ drying $\rightarrow$ padding with $\mathrm{SiO}_{2} \mathrm{NPs}$ dispersed in polydimethyl siloxane $\rightarrow$ drying $\rightarrow$ functionalized textile materials.

\section{Methods}

Dynamic light scattering (DLS)

For the characterization of the size and size distribution of the obtained dispersions, the dynamic light scattering (DLS) technique was used. Measurements were performed using a Zetasizer Nano instrument (Malvern).

$X$-ray diffraction (XRD)

Crystallinity and phase identity of the $\mathrm{ZnO}$ nanopowders were investigated using $\mathrm{X}$-ray diffraction on a Shimadzu XRD 7000 instrument.

Scanning electron microscopy (SEM)

The size and morphology of $\mathrm{ZnO}$ and $\mathrm{SiO}_{2} \mathrm{NPs}$ and respectively the surface morphology of textile treated samples was investigated by a FEI Quanta 200 Scanning Electron Microscope (Netherlands) with a GSED detector, at different magnification and accelerating voltage of $12.5 \mathrm{kV}-20 \mathrm{kV}$.

Whiteness degree of treated samples

In order to assess the influence of the functionalization treatments on the textile materials appearance, the $100 \%$ cotton fabrics were tested before and after treatments in terms of whiteness degree according to the SR EN ISO 105-J01:2003 standard.

Assessment of water-repellent properties

For the assessment of water-repellent properties, the treated samples with hybrid coatings based on $\mathrm{ZnO} / \mathrm{SiO}_{2} \mathrm{NPs}$ were tested from the wettability point of view, according to the drop test method (STAS 12751-89 standard), surface wetting resistance Spraytest (SR EN ISO 4920:2013 standard)

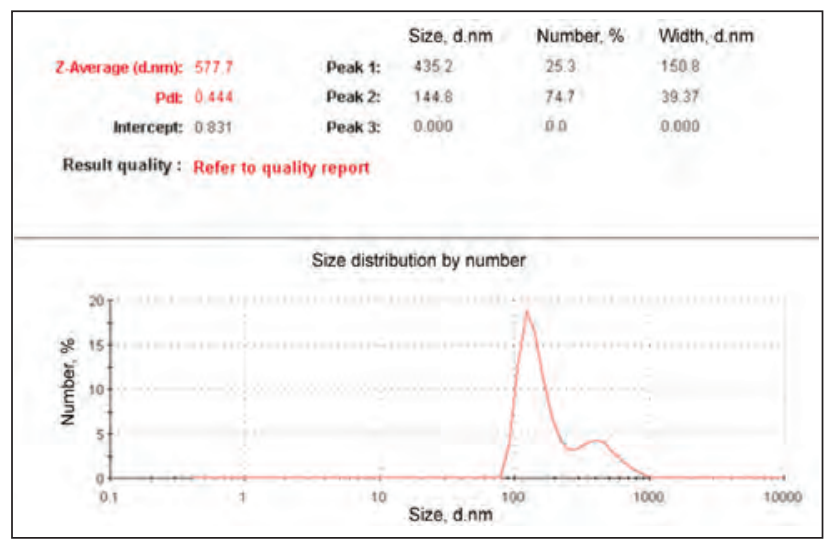

a
Assessment oil-repellent properties

The oil repellence of the PES samples was determined under static conditions using hydrocarbon resistance test (SR EN ISO 14419:2010 standard) with eight hydrocarbon liquids in a series of decreasing surface tension. Paraffin oil was denoted with the rating number 1 and $n$-heptane was given the rating number 8. Drops of the standard test liquids were placed on the fabric surface and observed for wetting. The repellence rating was the highest numbered test liquid that did not wet the fabric in 30 seconds.

\section{RESULTS AND DISCUSSION}

\section{Dynamic light scattering (DLS)}

Figure 1 shows the DLS diagrams of the obtained $\mathrm{ZnO}$ and $\mathrm{SiO}_{2} \mathrm{NPs}$ dispersions, presenting small dimensions and, in the case of $\mathrm{SiO}_{2}$ nanoparticles, good monodispersity.

The average size of the $\mathrm{SiO}_{2} \mathrm{NPs}$ is $158 \mathrm{~nm}$, with no other signal at higher values. In the case of ZnO NPs, the size distribution is bimodal, indicating the presence of two populations, with average size at $144 \mathrm{~nm}$ and $435 \mathrm{~nm}$. Moreover, ZnO NPs exhibit a broad particle size distribution, demonstrated by the polydispersity index of 0.444 and the high value of width of the peaks. The large range of nanoparticle size is due to the formation of the flower-like aggregated of smaller $\mathrm{ZnO}$ sheets, while the hydrothermal synthesis of such complex morphologies is very difficult to control.

\section{X-ray diffraction (XRD)}

The result of the diffractograms is specific to the phase of hexagonal wurtzite for all $\mathrm{ZnO}$ samples (figure 2).

The XRD peaks are sharp and intense, indicating that the nanopowders are highly crystalline. The diffractogram recorded for $\mathrm{SiO}_{2} \mathrm{NPs}$ (data not shown) contains no evident peaks, suggesting the amorphous phase of the silica nanoparticles.

\section{Scanning electron microscopy (SEM)}

The SEM image (figure $3, a$ ) reveals that ZnO NPs exhibit flower-like morphology, with pellets (sheets)

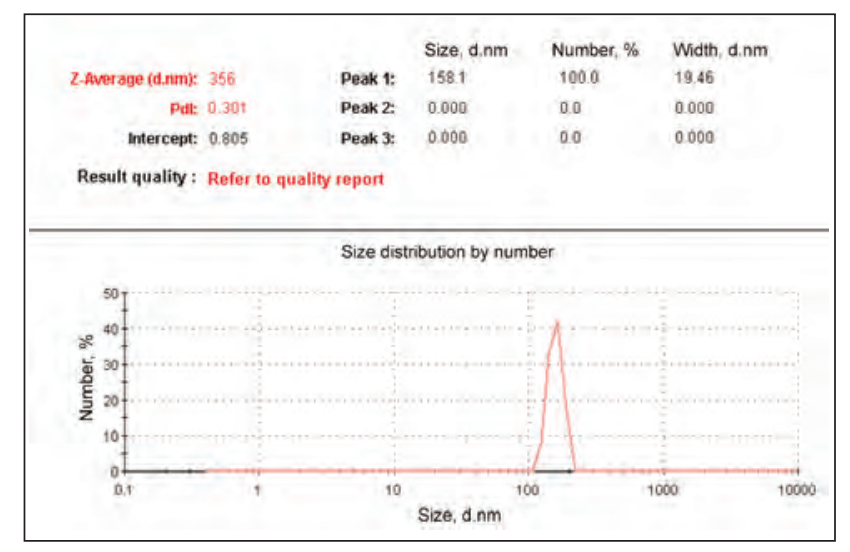

b

Fig. 1. Size and size distribution of: $a-\mathrm{ZnO} N P s ; b-\mathrm{SiO}_{2} \mathrm{NPs}$ obtained according the procedure described above 


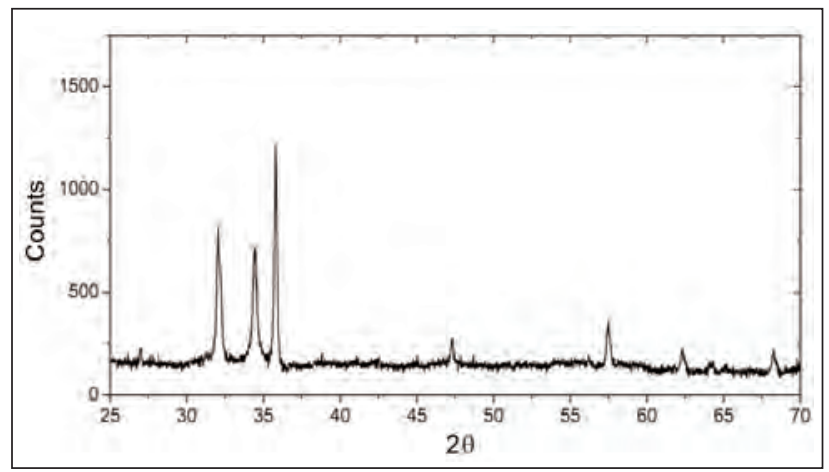

Fig. 2. The XRD diffractogram for the $\mathrm{ZnO}$ nanopowder

converged in a center. Some distinct sheets, unassociated are also present, corresponding to the particles with smaller size observed in DLS diagram. Figure $3, b$ presents a SEM micrography of $\mathrm{SiO}_{2}$ NPs, where it can be observed that the nanoparticles exhibit an increased monodispersity and quasi spherical shape.

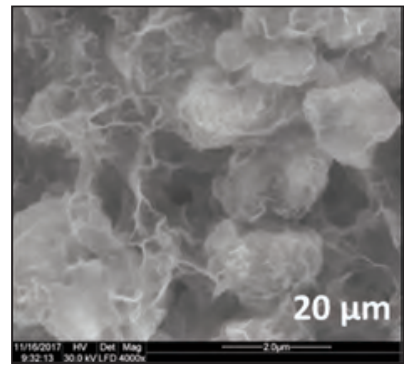

a

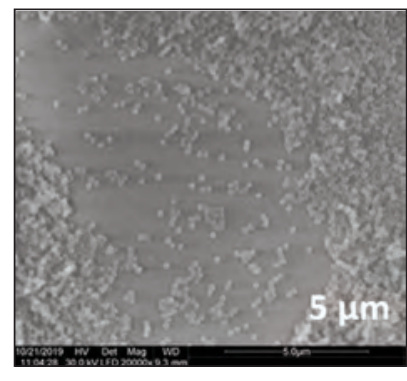

$\boldsymbol{b}$
Fig. 3. SEM images for: $a-\mathrm{ZnO} \mathrm{NPs} ; b-\mathrm{SiO}_{2} \mathrm{NPs}$

The surface morphology of cotton fibres untreated and treated with hybrid coatings based on $\mathrm{ZnO}$ flower-like/ $\mathrm{SiO}_{2} \mathrm{NPs}$ organically modified (ORMOSIL) is shown in figure 4 . The obtained micrographs reveal that the surface of the cotton fibres was not changed greatly by the subsequent coating process, therefore, the fibre bulk properties remained undamaged. The untreated cotton fabric showed a smooth and clean surface. The electronic images recorded for the treated fabric also show that the surface of the cotton fibers is covered with a relatively large number
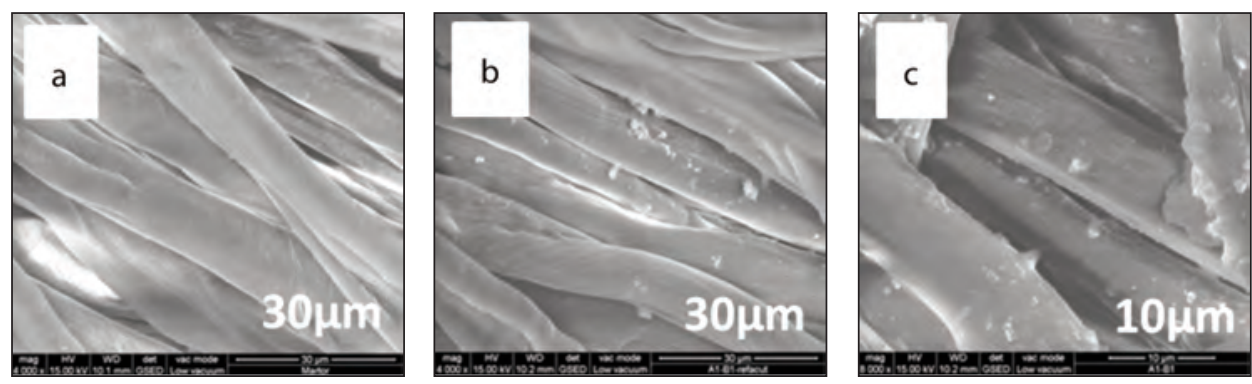

Fig. 4. SEM images of: $a$ - the native cotton fibers at low-magnification; $b$ - treated cotton fabric with hybrid coatings based on $\mathrm{ZnO} / \mathrm{SiO}_{2} \mathrm{NPs}$ at low magnification; $c$ - treated cotton fabric with hybrid coatings based on $\mathrm{ZnO} / \mathrm{SiO}_{2} \mathrm{NPs}$ at higher magnification

industurià textilă of $\mathrm{ZnO} / \mathrm{SiO}_{2} \mathrm{NPs}$ with different sizes, distributed as an uneven layer of agglomerated particles. Moreover, the SEM images reveal a hierarchical rough structure, which can contribute to the hydrophobic behavior of the cotton substrate.

\section{Whiteness degree of treated samples}

The values obtained for the whiteness degree of $100 \%$ cotton fabric before and after the functionalization treatment are shown in table 1.

The values obtained for the whiteness degree, both on the Berger and CIE scales, reveal the fact that the hydrophobization/oleophobization combined treat-

Table 1

\begin{tabular}{|c|c|c|}
\hline \multicolumn{2}{|c|}{ WHITENESS DEGREE OF TREATED SAMPLE } \\
\hline \multirow{2}{*}{ Sample } & \multicolumn{2}{|c|}{ Whiteness degree } \\
\cline { 2 - 3 } & Berger & CIE \\
\hline Untreated & 65.07 & 66.8 \\
\hline $\mathrm{ZnO} / S i O_{2} \mathrm{NPs}$ & 65.55 & 66.92 \\
\hline
\end{tabular}

ment does not significantly change the appearance of the treated textile material. This indicates the high transparency of the hybrid $\mathrm{ZnO} / \mathrm{SiO}_{2} \mathrm{NPs}$ based coating, which is very beneficial for the retention of the original color expression on source colorful fabric.

\section{Assessment of water- and oil-repellent properties}

The values obtained for wetting capacity, surface wetting resistance and oil repellency are presented in table 2.

The results presented in table 2 show that the application of hybrid coatings provided both water- and oil-repellent properties to the cotton fabric. The textile material treated with hybrid coatings has a low wetting capacity, with high values of water absorption time (>15 minutes), showing an acceptable hydrophobic effect. Treated samples tested through the superficial wetting test (Spraytest), have shown a hydrophobic effect characterized by the partial wetting of the test specimen, with a rating of 2.5 on the ISO scale and 75 on the AATCC photographic scale, being considered an acceptable water repellent degree, which was obtained under the conditions of the selected experimental protocol. Fabric samples exhibit an oil repellency degree of 6 , which defines the $100 \%$ cotton fabric textile treated with $\mathrm{ZnO} /$ $\mathrm{SiO}_{2} \mathrm{NPs}$ as an efficient substrate for the rejection and protection against oily substances. 


\begin{tabular}{|l|c|c|c|}
\hline \multicolumn{4}{|c|}{ WATER AND OIL REPELLENCY } \\
\hline \multirow{2}{*}{ Characteristic } & \multicolumn{2}{c|}{ Sample } \\
\cline { 2 - 4 } & $\begin{array}{c}\text { Untreated } \\
\text { cotton fabric }\end{array}$ & $\begin{array}{c}\text { Functionalized } \\
\text { cotton fabric }\end{array}$ \\
\hline Wettability (s) & Immediate & 900 \\
\hline $\begin{array}{l}\text { Wetting } \\
\text { resistance }\end{array}$ & ISO scale & 0 & 2.5 \\
\cline { 2 - 4 } & $\begin{array}{l}\text { AATCC photo- } \\
\text { graphic scale }\end{array}$ & 0 & 75 \\
\hline \multicolumn{2}{|l|}{ Oil repellency } & 0 & $6^{*}$ \\
\hline
\end{tabular}

Note: *Rating is the highest numbered test liquid which did not wet the fabric in 30 seconds; name of the highest numbered test liquid: n-decane - C10 with Rating 6 .

\section{CONCLUSIONS}

Hybrid materials based on the mixture of $\mathrm{ZnO}$ and $\mathrm{SiO}_{2}$ nanoparticles have been studied as cost effective, ecological coating for textiles hydrophobization. The prepared $\mathrm{SiO}_{2} \mathrm{NPs}$ have quasi spherical shape, while $\mathrm{ZnO}$ NPs possess flower-like morphology. The nanoparticles combination, with different dimensions and shapes, allow a suitable roughness to obtain the increase regarding contact angle values, thus, increasing the hydrophobicity at low nanoparticle concentration and low hydrophobic polymer concentration in the coating material. The colloidal systems of both $\mathrm{SiO}_{2}$ and $\mathrm{ZnO} \mathrm{NPs}$ are stable, according to the DLS diagrams and facilitate a simple procedure for the textile treatment, without sonication or other methods of dispersion as preliminary steps.

The hydrophobization/oleophobization combined treatment achieved with hybrid coatings based on flower-like $\mathrm{ZnO} / \mathrm{SiO}_{2} \mathrm{NPs}$ organically modified (ORMOSIL) does not significantly change the appearance of the treated textile material. The surface of the cotton fibers was not changed significantly by the subsequent coating process, while the fibre bulk properties remained undamaged. The fabric samples exhibited a 75 water-repellent degree and a 6 oil repellency degree.

\section{ACKNOWLEDGMENTS}

This work was supported by a grant of the Romanian Ministry of Research and Innovation, CCCDI - UEFISCDI, project number PN-III-P1-1.2-PCCDI-2017-0743/ contract 44/2018, Project 3 and Project 5, within PNCDI III.

\section{REFERENCES}

[1] Foorginezhad, S., Zerafat, M.M., Fabrication of superhydrophobic coatings with self-cleaning properties on cotton fabric based on Octa vinyl polyhedral oligomeric silsesquioxane/polydimethylsiloxane (OV-POSS/PDMS) nanocomposite, In: Journal of Colloid and Interface Science, 2019, 540, 78-87

[2] Li, M., Liu, N., Chen, J., Li, Q., Simple construction based on epoxy-bonded super-hydrophobic anti-corrosion coating, In: Journal of the Taiwan Institute of Chemical Engineers, 2019, 95, 682-691

[3] Verbič, A., Gorjanc, M., Simončič, B., Zinc Oxide for Functional Textile Coatings Recent Advances, In: Coatings, 2019, 9 , 550-576

[4] Lorwanishpaisarn, N., Kasemsiri, P., Srikhao, N., Jetsrisuparb, K., Knijnenburg, J., Hiziroglu, S., Pongsa, U., Chindaprasirt, P., Fabrication of durable superhydrophobic epoxy/cashew nut shell liquid based coating containing flowerlike zinc oxide for continuous oil/water separation, In: Surface and Coatings Technology, 2019, 366, 106-113

[5] Tian X., Li, Y., Wan, S., Wu, Z., Wang, Z., Functional Surface Coating on Cellulosic Flexible Substrates with Improved Water-Resistant and Antimicrobial Properties by Use of ZnO Nanoparticles, In: Journal of Nanomaterials, 2017, 2017, 1-9

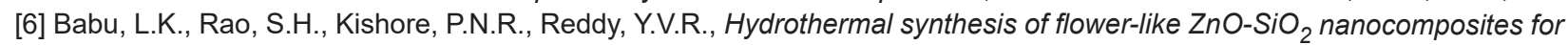
solar light-induced photocatalysis and anti-bacterial applications, In: Materials Research Express, 2019, 6, 8, 1-12

[7] Budunoğlu, H., Yildirim, A., Guler, M.O., Bayindir, M., Highly Transparent, Flexible, and Thermally Stable Superhydrophobic ORMOSIL Aerogel Thin Films, In: ACS applied materials \& interfaces, 2011, 3, 539-545

[8] Li, B., Wang, Y., Facile Synthesis and Enhanced Photocatalytic Performance of Flower-like ZnO Hierarchical Microstructures, In: Journal of Physical Chemistry, 2010, 114, 2, 890-896

[9] Stober, W., Fink, A., Bohn, E., Controlled growth of monodisperse silica spheres in the micron size range, In: Journal of Colloid and Interface Science, 1968, 26, 1, 62-69

Authors:

\section{LAURA CHIRILA ${ }^{1}$, LUDMILA OTILIA CINTEZA², MARIA TANASE², DIANA ELENA RADULESCU ${ }^{1}$, DENISA MARIA RADULESCU ${ }^{1}$, IOANA RODICA STANCULESCU ${ }^{3}$ \\ ${ }^{1}$ National Research and Development Institute for Textiles and Leather, 16 Lucretiu Patrascanu Street, 030508, Bucharest, Romania e-mail: office@incdtp.ro}

2University of Bucharest, Physical Chemistry Departament, 4-12 Regina Elisabeta Street, 030018, Bucharest, Romania ${ }^{3}$ Horia Hulubei National Institute of Research and Development for Physics and Nuclear Engineering, 30 Reactorului Street, 077125, Magurele, Romania 


\section{Investigation of the comfort properties of traditional woven fabrics with different structural parameters}

DOI: 10.35530/IT.071.04.1701

\section{ABSTRACT - REZUMAT}

\section{Investigation of the comfort properties of traditional woven fabrics with different structural parameters}

Turkish traditional Buldan weavings are known as special fabrics in terms of providing comfortable clothes which are known to be natural and healthy in Denizli, Turkey. The research presented in this paper assesses the effects of different fabric structural parameters of Buldan fabrics on comfort properties such as thermal resistance, thermal absorptivity, water vapour permeability and air permeability. Five different Buldan fabrics woven with different fabric structural parameters were produced. According to test results, cotton/Tencel Buldan fabrics indicated similar comfort properties with the $100 \%$ cotton Buldan fabric properties. Additionally, the lowest thermal absorptivity was observed from $100 \%$ cotton Buldan fabrics which give the warmth feeling among the evaluated samples.

Keywords: Buldan woven fabric, fabric structural parameters, thermal resistance, water vapour permeability, air permeability.

\section{Investigarea proprietăților de confort ale țesăturilor tradiționale cu diferiți parametri structurali}

Țesăturile tradiționale turcești Buldan sunt cunoscute ca țesături speciale din punctul de vedere al confortului îmbrăcămintei și al originii naturale în Denizli, Turcia. Cercetările prezentate în această lucrare evaluează influența diferiților parametri structurali ai țesăturilor Buldan asupra proprietăților de confort, precum rezistența termică, absorbția termică, permeabilitatea la vapori de apă și permeabilitatea la aer. Au fost produse cinci țesături Buldan cu diferiți parametri structurali. Conform rezultatelor testelor, țesăturile Buldan din bumbac/Tencel au indicat proprietăți de confort similare cu cele ale țesăturilor Buldan din 100\% bumbac. În plus, cea mai mică absorbție termică a fost observată la țesăturile Buldan din 100\% bumbac, care dau senzația de căldură.

Cuvinte-cheie: țesătură Buldan, parametri structurali ai țesăturii, rezistență termică, permeabilitate la vapori de apă, permeabilitate la aer

\section{INTRODUCTION}

Buldan which is a town of Denizli in Turkey is the weaving center for unique Buldan fabric. The weaving history of Buldan is very old. Today, textile sector has become a way of life in Buldan with workshops and factories as the small industries have developed [1]. Traditional Buldan weavings are known as special fabrics in terms of providing comfortable clothes which are known to be natural and healthy. Buldan fabric is generally known to be produced from natural fibers such as cotton, wool, linen and silk in the historical sources. And it is also known with its traditional name as "Buldan twisted clothes" owing to fabric structure with high twisted yarns. Buldan fabric is a plain weave which is the basic and most durable weave type. Although high twisted yarns are generally preferred as weft yarns, high twisted warp yarns may be also preferred in the fabric construction. The fabric gains its high wrinkle feature with the hot soap washing process. Since the wrinkled fabric width decreases with respect to high yarn twist level, those fabrics do not contact the human body which results with thermal insulation owing to air gaps. At the same time, since the Buldan fabrics are woven with high twisted yarns, they provide ease of movement owing to their flexibility as well as cooling effect owing to the air gaps in the curly surface. High sweat absorption of Buldan fabrics made of cotton is also another attractive advantage for the consumers demanding for healthy products [2-6]. It has been also observed that Buldan fabrics have been utilized for apparel sectors where they have been preferred for woman's blouses especially [3, 6]. As the Buldan fabrics have been produced in a traditional way, the productions with semi and full automatic weaving machines have been in progress with the developing technology [7]. It was mentioned in the literature that today's Buldan weavings have lower yarn twists when compared to older Buldan fabrics. Also it is supported that early Buldan fabric structures were much crimped and had higher fineness comparing to todays' Buldan fabrics sold in the market. Today most of the Buldan fabrics have been woven in the industrial factories blending with synthetic yarns. When the warp yarns are selected with low yarn twist level and the weft yarns are selected 
with high twist level or vice versa, this fabric quality is called as $50 \%$ twisted Buldan cloth. Today there are fewer accessible $100 \%$ twisted Buldan clothes produced on hand looms [8-9].

Buldan fabrics are highly preferred especially for summer clothes owing to their soft and comfortable feeling. Thermal comfort properties for any textile products can be listed as thermal conductivity, thermal resistance, thermal absorptivity, water vapour permeability, air permeability and moisture transport. The permeability of the fabrics depends on the raw material (such as fiber type, fineness and cross section etc.), yarn properties (such as linear density, twist level, yarn hairiness, etc.), and fabric structural properties (such as geometrical properties, weave type, fabric thickness, porosity etc.) as well as the finishing processes applied to those fabrics. For an acceptable thermal comfort of an ideal fabric structure: i) a fabric should reveal high thermal resistance for cold protection, ii) a fabric should indicate low water vapour resistance for an effective heat transfer for warm climate conditions, iii) a fabric should reveal high moisture transfer characteristics [10-11].

Thermal conductivity of any fabric has a strong relationship with the air trapped in the fabric and the thermal conductivity coefficient of the fibers made of them. Since the thermal conductivity coefficient of the air is low, fabrics having higher amount of air have also low thermal conductivity coefficient [12]. As the material thickness and the air trapped inside it increase, it is observed that the materials' thermal resistance and water vapour resistance also increase while its air permeability decreases. There should be a high ratio of air in a textile material which has high thermal insulation. This is because of the lower thermal conductivity coefficient of the air compared to textile materials. Stagnant air is an ideal insulating material. When the fibers' thermal conductivity coefficients (Watt/meter-Kelvin) are considered, coefficient of thermal conductivity for cotton is 71 while this value is 25 for stagnant air [10-14]

In literature, it has been observed that factors such as the hydrophilic nature of the fiber forming the fabric structure, high thermal conductivity and high water vapour permeability ensure that the liquid can be delivered rapidly to the outer layers [15]. Thermal absorptivity and water vapour permeability properties are known to be increasing with the highly twisted yarns in the fabrics. It was also observed that the fabrics with high twisted yarns gave cool feeling owing to high thermal absorptivity. However thermal resistance decreased as the yarn twist increased [10].

As the linear density of yarns utilized in the fabric decreases, thermal resistance and thermal absorptivity values decrease while the water vapour permeability increases. Thermal resistance values increase as the fabric thickness increase whereas water vapour and air permeability properties decrease. When the fiber properties of cotton, viscose and Tencel were evaluated in terms of comfort properties in a research; Cotton fiber revealed higher thermal resistance and warmer feeling, Tencel fiber indicated higher water vapour permeability and viscose fiber indicated higher air permeability [16]. Thermal resistivity decreased with the increasing yarn twist while thermal absorptivity and water vapour permeability increased. It was also observed that fabrics with high twisted yarns gave cooler feelings owing to high thermal absorptivity features [17]. In another study it was also declared that there are many parameters related to fabric structure which influence water vapour permeability. Those parameters were followed as: i) fiber properties (type, count, composition, porosity, cross section), ii) yarn properties (linear density, yarn diameter, twist, hairiness, yarn geometry), iii) fabric properties (fabric porosity, thickness and warp/weft density) [12].

It was declared in the literature that fabric thickness and fiber type indicated high correlation with the water vapour transport ratio. However, the moisture transport did not indicate any relationships with those two factors. Most of the study emphasized that there was a high relationship between water vapour permeability and air permeability properties [12, 18]. Fabrics have a porosity structure owing to many fiber combinations. Water vapour transfer occurs among the fibers and yarns' space as well as within the fibers. Since diffusion coefficient of water vapour which transfers within the fibers is lower than the coefficient of water vapour which transfers through the air; Water vapour diffusion increases as the amount of present air increases. Diffusion coefficient of water vapour permeability through the air is $0.239 \mathrm{~cm}^{2} \cdot \mathrm{s}^{-1}$ while this value decreases to $10^{-7} \mathrm{~cm}^{2} \cdot \mathrm{s}^{-1}$ through the cotton fabric. Water vapour in the fabric is known to be spreading from the center to fabric surface and from the fiber inner surface to the fiber outer surface hence it evaporates from the fabric surface. This diffusion theorem does not work according to Fick law in the hydrophilic fibers which highly absorb the water molecules. Swelling of the fibers result with less air spaces hence the diffusion spread decrease [12, 19]. Air permeability which facilitates easier thermal transport and determines the breathability properties of fabrics is an important parameter for comfort properties. Air permeability of the fabrics is influenced from the fabric porosity. Fabric porosity which affects the permeability properties of the fabric is the total space volume depending mainly on the fabric geometry, raw materials and yarn properties. Porosity between the fibers and fabrics depend on the structural factors such as fiber fineness, fiber cross section, weave type, yarn density and yarn twist. When the air flow in the porous structure is considered, the shape, layout and size distribution of the spaces are accepted as the important factors. It was also observed that there is a reverse proportion between the air permeability of the fabrics with their thickness [12].

Since fabric density determines the pores' size, it is an important parameter for air permeability. Fabric porosity decreases as the fabric density increases. 
When the air permeability of the fabric is associated with cover factor, it was observed that tight fabrics which have little pores with high cover factor prevent the air permeability [12]. Since the structural parameters of the fabrics such as its consisting yarns' twist, linear density, packing ratio influence the porosity between and within the yarn porosity, those parameters influence the total air permeability ratio. When the yarn twists in cotton fabrics were evaluated, it was concluded that porosity increased with the twist ratio. Yarn diameter was also considered as an important parameter since it determined fabric porosity and cover factor [12, 20].

In literature, there are not many studies considering the relationship between the unique fabric groups "Buldan fabric" and the fabrics' structural properties such as yarn composition, yarn twist, fabric weight, and fabric thickness in terms of thermal comfort properties. This study aims to contribute to literature by investigating the thermal resistivity $\left(\mathrm{m}^{2} \cdot \mathrm{KW}^{-1}\right)$, thermal absorptivity $\left(\mathrm{Wm}^{-2} \mathrm{~s}^{1 / 2} \mathrm{~K}^{-1}\right)$, relative water vapour permeability (\%) and air permeability $\left(\mathrm{l} / \mathrm{m}^{2} / \mathrm{s}\right)$ properties of Buldan fabrics produced with different fabric structural parameters. This study is thought to be useful in terms of thermal evaluations of local Buldan fabrics which will more likely to be encountered in apparel clothes.

\section{MATERIALS AND METHODS}

\section{Material}

In this study, plain woven traditional Buldan fabrics were produced on Sulzer projectile weaving loom. The effect of constructional parameters such as yarn count, fabric density, yarn twist, fabric thickness, and fabric unit weight were indicated as in table 1. Those parameters were thought to be influential factors on fabrics' thermal properties as well as on water vapour permeability and air permeability properties evaluated within the study. Microscopic images of original and 20 times magnified samples which were taken under a microscope (Mshot Digital Microscope Camera MS60) coupled to a digital camera were also revealed in figure 1.

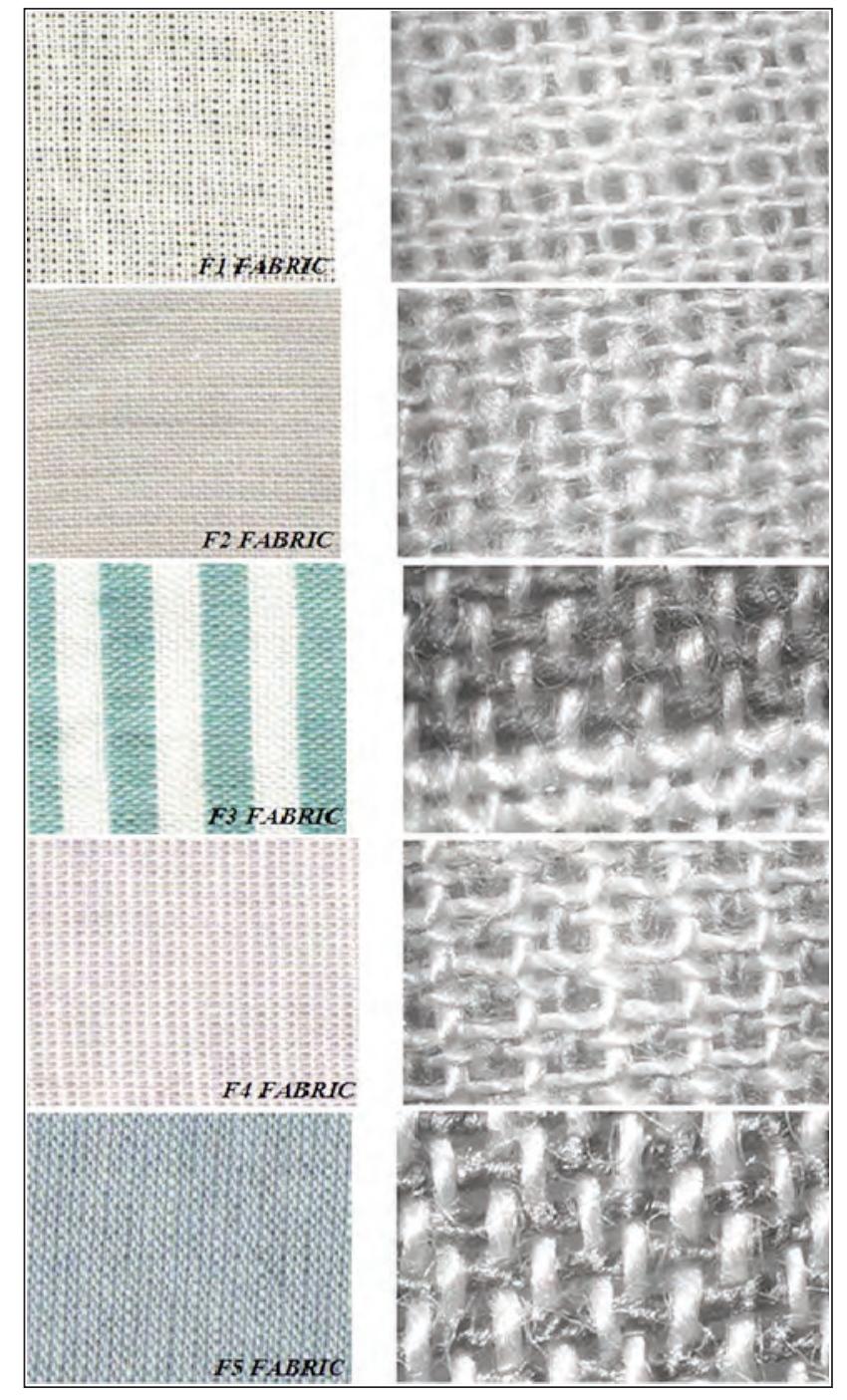

Fig. 1. Buldan fabrics' photograph and microscopic $(\times 20)$ images

\section{Methods}

In this study it was aimed to investigate the effect of fabric structural parameters on some comfort properties of Buldan fabrics. For this, Alambeta, Permetest and SDL Atlas M021A model Air Permeability Tester devices were used for the evaluation of thermal comfort, water vapour and air permeability properties

Table 1

\begin{tabular}{|c|c|c|c|c|c|c|c|c|c|}
\hline \multicolumn{10}{|c|}{ CONSTRUCTIONAL PARAMETERS OF BULDAN FABRICS } \\
\hline \multirow{2}{*}{$\begin{array}{l}\text { Fabric } \\
\text { code }\end{array}$} & \multirow{2}{*}{$\begin{array}{c}\text { Fabric } \\
\text { composition } \\
(\%)\end{array}$} & \multicolumn{2}{|c|}{$\begin{array}{c}\text { Yarn count } \\
(\mathrm{Ne})\end{array}$} & \multicolumn{2}{|c|}{$\begin{array}{c}\text { Fabric density } \\
\text { (thread/cm) }\end{array}$} & \multicolumn{2}{|c|}{$\begin{array}{c}\text { Yarn Twist } \\
(\mathrm{T} / \mathrm{m})\end{array}$} & \multirow{2}{*}{$\begin{array}{c}\begin{array}{c}\text { Fabric } \\
\text { thickness } \\
(\mathrm{mm})\end{array} \\
\end{array}$} & \multirow{2}{*}{$\begin{array}{c}\text { Fabric unit } \\
\text { weight } \\
\left(\mathrm{g} / \mathrm{m}^{2}\right)\end{array}$} \\
\hline & & Warp & Weft & Warp & Weft & Warp & Weft & & \\
\hline $\mathrm{F} 1$ & $100 \%$ Cotton & $50 / 1$ Cotton & 30/1 Cotton & 26 & 24 & $971 \mathrm{Z}$ & $804.6 \mathrm{Z}$ & 0.27 & 86.9 \\
\hline $\mathrm{F} 2$ & $\begin{array}{c}30 \% \text { Cotton - } \\
70 \% \text { Tencel }\end{array}$ & $50 / 1$ Cotton & 20/1 Tencel & 28 & 22 & $899.8 \mathrm{Z}$ & $732.8 \mathrm{Z}$ & 0.33 & 102 \\
\hline F3 & $\begin{array}{c}30 \% \text { Cotton - } \\
70 \% \text { Tencel } \\
\end{array}$ & $50 / 1$ Cotton & 20/1 Tencel & 26 & 23 & $685.8 \mathrm{Z}$ & $667.2 \mathrm{Z}$ & 0.31 & 105 \\
\hline $\mathrm{F} 4$ & $\begin{array}{c}65 \% \text { Cotton - } \\
35 \% \text { Tencel } \\
\end{array}$ & 50/1 Cotton & $\begin{array}{c}20 / 1 \\
\text { Cotton/Tencel }\end{array}$ & 26 & 26 & $710 \mathrm{Z}$ & $675 Z$ & 0.33 & 107.4 \\
\hline F5 & $\begin{array}{c}35 \% \text { Cotton - } \\
65 \% \text { Tencel }\end{array}$ & 30/1 Cotton & 20/1 Tencel & 26 & 21 & $1088.4 \mathrm{Z}$ & Core-Spun & 0.34 & 107.7 \\
\hline
\end{tabular}


respectively. Three repeats were conducted for each sample measurement. Fabric samples were conditioned at $65 \pm 2 \%$ relative humidity and $20 \pm 2^{\circ} \mathrm{C}$ for 24 hours in accordance with the ASTM D 1776-08 (2009) standards prior to all mentioned tests.

Thermal resistivity and thermal absorptivity

Thermal properties such as thermal resistance $(r)$ and thermal absorptivity $(b)$ of Buldan fabrics were measured by using Alambeta instrument. Average of three measured results was calculated as the means for determining the means. The definition of thermal properties mentioned in the study as; thermal resistance and thermal absorptivity are briefly summarized below.

Thermal resistance is a measure of the body's ability to prevent heat from flowing through it. Under a certain condition of climate, if the thermal resistance of clothing is small, the heat energy will gradually reduce with a sense of coolness [20]. Thermal resistance has a relationship with fabric thickness and thermal conductivity coefficient as indicated in equation (1) [21]:

$$
r=\frac{h}{\lambda}\left(\mathrm{m}^{2} \mathrm{~K} / \mathrm{W}\right)
$$

where $r$ is thermal resistance, $h$ - fabric thickness (m), $\lambda$ - thermal conductivity coefficient (W/mK).

Thermal absorptivity is the objective measurement of the warm-cool feeling of fabrics. This parameter allows assessment of the fabric's character in the aspect of its "cool-warm" feeling [22]. Thermal absorption is the heat flow when the two materials of different temperature contact each other. If a skin contacted fabric has lower temperature than the skin, heat flow from the skin to the fabric will result with a cool feeling. Low thermal absorption provides warmer feeling while high thermal absorption leads to cooler feeling. This parameter is important especially for the comfort property of the cloths at first dressing moments in cold winter days. The equation (2) displays the calculation of thermal absorptivity. As it is observed thermal absorptivity is directly proportional with materials' thermal conductivity, density and specific heat [22-24].

$$
b=(\lambda \rho c)^{1 / 2}\left(\mathrm{Ws}^{1 / 2} / \mathrm{m}^{2} \mathrm{~K}\right)
$$

where $\lambda$ is thermal conductivity $(\mathrm{W} / \mathrm{mK}), \rho-$ density $\left(\mathrm{kg} / \mathrm{m}^{3}\right), c-$ specific heat $(\mathrm{J} / \mathrm{kgK})$.

Relative water vapour permeability

Relative water vapour permeability is the fabric ability to transfer water vapour in percentage scale.

Especially for products which are used in hot weather or for active sports when perspiring is maximal, water vapour permeability is one of the most important comfort parameters. If the evaporative resistance of the samples is too high to transmit heat, the stored heat in the body cannot be dissipated and causes an uncomfortable sensation. Garments which have high water vapour permeability feature can easily ensure evaporation of moisture from body after sweating and enhances the sense of comfort [25-26]. Among this study, relative water vapour permeability was measured on 'Permetest' instrument working on similar skin model principle according to EN ISO 11092 test standard.

Air permeability test

Air permeability of the fabrics was measured based on EN ISO 9237 standard using a SDL Atlas Digital Air Permeability Tester Model M $021 \mathrm{~A}$ at $20 \pm 2^{\circ} \mathrm{C}$ and $65 \% \pm 4 \%$ humidity [27]. Measurements were performed by application under $100 \mathrm{~Pa}$ air pressure per $20 \mathrm{~cm}^{2}$ fabric surface.

Measurement of fabric thickness

Fabric thickness should be considered since it determines most of the physical properties of the fabrics. Buldan woven fabrics' thickness were measured according to ASTM D1777-96 (2007) by using R\&B J.H. Heal test equipment in order to observe the effects of different constructional parameters on fabric thickness.

\section{RESULTS AND DISCUSSION}

\section{Analysis of the thermal resistivity}

In figure 2, the thermal resistivity values of Buldan woven fabrics are presented. According to figure 2, fabric thickness and fabric weight are considerable factors on thermal resistivity of fabrics having different raw materials at different compositions. It was observed that fabrics having low fabric weight and fabric thickness revealed lower thermal resistivity (F1 and F3). Some researchers also declared in their studies that thermal resistance increases with the increase of material thickness and air entrapped in the fabric [28]. It can also be emphasized that fabric thickness was a considerable factor for thermal resistivity. This result might also be supported with the comparison of thermal resistivity results of $\mathrm{F} 1$ and F2 fabrics. F2 fabric indicated higher thermal resistivity which has lower fabric weight but higher fabric thickness value compared to $\mathrm{F} 1$ fabric.

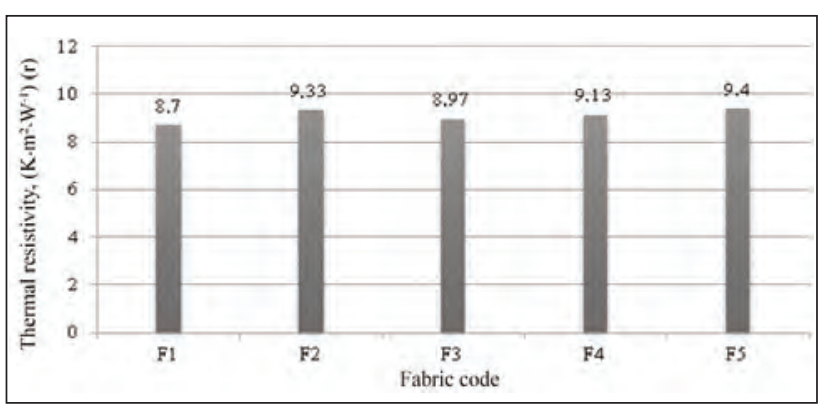

Fig. 2. Thermal resistivity values of fabrics

When the F2 and F3 fabrics which have the same fabric compositions were evaluated; it was observed that F3 fabric having high fabric weight and also with low fabric thickness indicated lower thermal resistivity than F2 fabric which has low fabric weight but high fabric thickness.

When the F4 and F5 fabrics having different cotton/ Tencel ratios with same fabric weight were evaluated, 
it was observed that they revealed similar thermal resistivity values. Additionally, among the low fabric weight groups as F1, F2 and F3; F1 fabric indicated lower thermal resistivity. This result might be attributed to reducing effect of high twisted weft and warp yarns in addition to low fabric weight of F1. As it is known, thermal resistivity decreases as the yarn twist increases. This result is supported with Ozdil et al. study where they concluded that thermal resistance values decreased with the yarn twist [17].

\section{Analysis of the thermal absorptivity}

Buldan woven fabrics are preferable owing to their cool feeling properties in summer times. Unique property of cotton fiber combined with high twisted yarns provide garments keeping the microclimate conditions constant owing to Buldan fabrics' crimped surface. The result of crimped fabric surface, garments with Buldan fabrics do not contact the skin directly. In figure 3, the thermal absorptivity values of Buldan woven fabrics are presented. According to figure 3, F1 and F2 fabrics indicating lower thermal absorptivity are expected to provide warmer feeling while F3, F4 and F5 fabrics which reveal higher thermal absorptivity values are expected to give cool feeling.

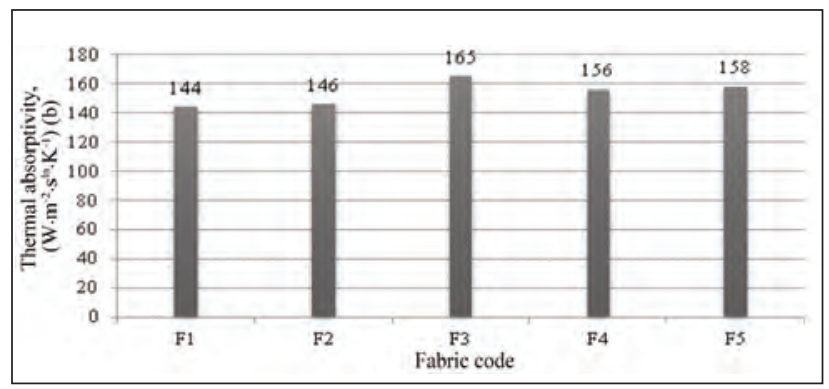

Fig. 3. Thermal absorptivity values of fabrics

When the F1 and F2 fabrics which indicate lower thermal absorptivity are considered, it is observed that those fabrics have low fabric weight. However, in the manner of fiber composition, $\mathrm{F} 1$ fabric made of $100 \%$ cotton and F2 fabric made of cotton/Tencel did not vary between each other in terms of thermal absorptivity results. Among five different Buldan woven fabrics, $100 \%$ cotton F1 fabric with low fabric weight and low thickness indicated the lowest thermal absorptivity with the warmth feeling.

F4 and F5 fabrics which have the same fabric weight and thickness but different fiber composition were evaluated, F4 fabric indicated slightly lower thermal absorptivity. This result might be attributed to higher cotton ratio of $\mathrm{F} 4$ fabric composition.

Among all fabric groups, F3 fabric indicated the highest thermal absorptivity with cool feeling. Considering the F3, F4 and F5 fabrics revealing the highest thermal absorptivity values, it was observed that F3 fabric indicated the highest value. This result may be attributed to higher Tencel composition in F3 fabric compared to F4 and F5 fabrics.
In the early literature, it was declared that thermal absorptivity increases as the yarn twist of the fabrics increased $[10,17]$. However, in this study related to Buldan fabrics, maximum thermal absorptivity was obtained from F3 fabrics which have the lowest yarn twist. Obtained results might be explained as follow; in figure 3, it was observed that highest thermal absorptivity (coolest feeling) was obtained from F3 fabric while lowest thermal absorptivity (warmth feeling) was found F1 fabric. On the other hand, when the air permeability values of these fabrics were evaluated, just opposite of this situation was encountered with where F3 fabric had the minimum air permeability and F1 fabric had the maximum air permeability (in figure 5). This result may require considering the evaluation of thermal absorptivity and air permeability properties together. Since the fabric with low air permeability (F3) has low amount of air trapped inside, it is thought that low amount of stagnant air in the fabric structure might result with cool feeling. Hence fabrics with low air permeability will result with cool feeling. Since air passing through the fabric provides the increment of the stagnant air in the fabrics' pores with high air permeability properties, thermal insulation of the fabric will increase with warmth feeling.

\section{Analysis of the water vapour permeability}

In figure 4, the water vapour permeability values are presented. Highest water vapour permeability belongs to $100 \%$ cotton $\mathrm{F} 1$ fabric with the lowest fabric weight and fabric thickness. F2, F3, F4 and F5 indicated similar water vapour permeability values. When the fabric constructional parameters are considered, fabric thickness was a considerable factor for water vapour permeability.

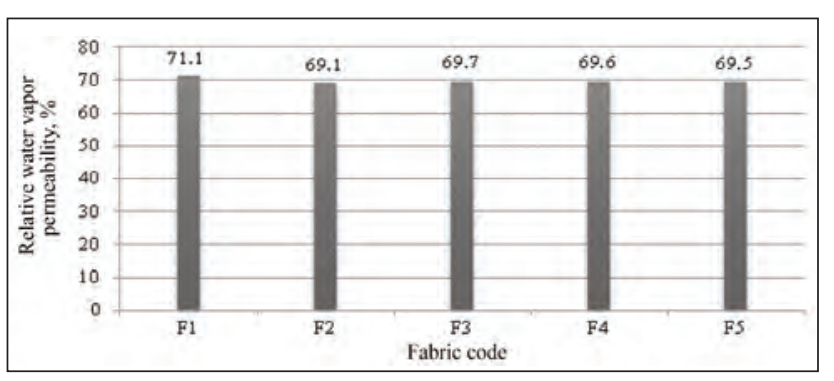

Fig. 4. Water vapour permeability values of fabrics

Although, F2, F3, F4 and F5 fabrics having the different fabric weight between each other (except for the fabrics of F4 and F5) but the fabric thickness values were similar to each other. Since those fabrics indicated similar water vapour permeability results, it may be concluded that fabric thickness factor was more dominant on water vapour permeability property. On the other hand, F4 and F5 fabrics having different fiber blend ratios of cotton/Tencel but having same fabric weight and fabric thickness revealed similar water vapour permeability which indicated that fiber blend ratio of cotton/Tencel fabrics was not a prominent factor on water vapour permeability values. 


\section{Analysis of the air permeability}

In figure 5, the air permeability values of fabrics are presented. According to figure 4, the highest air permeability was obtained from F1 fabric. When the constructional property of $\mathrm{F} 1$ fabric was evaluated, it was observed that F1 fabric had lowest fabric weight and fabric thickness. Additionally, yarns consisting F1 fabric had higher twist level compared to F2, F3 and F4 fabrics. When the microscopic images (figure 1) of Buldan fabrics were observed, it may be observed that $\mathrm{F} 1$ has a more porosity surface structure.

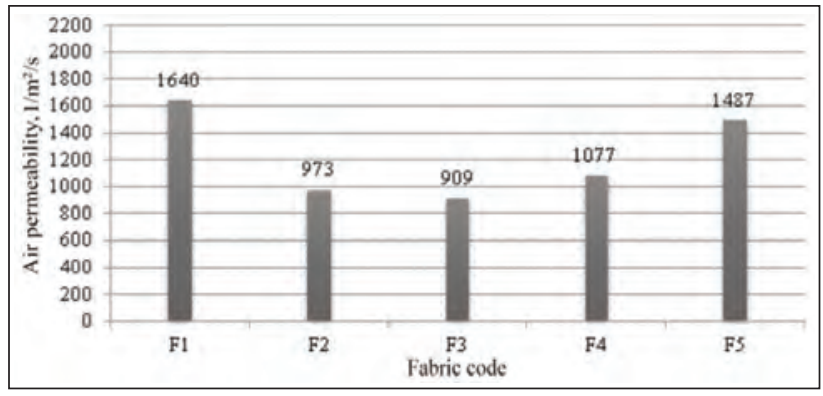

Fig. 5. Air permeability values of fabrics

On the other hand, the reason for F5 fabric permitting high air permeability despite its high fabric weight and fabric thickness may be attributed to its high twisted warp yarns. As it is known, as the yarn twist level increases, the surface porosity of the fabric will increase resulting with high air permeability. According to figure 5 , the lowest air permeability value was obtained from F3 fabric where F2 followed it. This result may be explained with low yarn twists of F3 fabric despite its moderate fabric weight. Since low twisted yarns had bulkier structure resulting with less porous fabric structure as well as with low air permeability property.

\section{CONCLUSIONS}

The research presented in this paper assessed the effects of different constructional parameters on comfort properties of Turkish traditional Buldan woven fabrics. Buldan woven fabrics made of $100 \%$ cotton and cotton/Tencel blends were investigated in terms of thermal properties, water vapour and air permeability properties regarding to their fabric structural parameters such as fiber blend composition, yarn twist ratio, fabric unit weight and fabric thickness.

Experimental results showed that fabrics woven with cotton/Tencel blends indicated similar thermal resistivity values with those made from $100 \%$ cotton. Additionally, it was observed that fabric thickness was the most effective parameter on thermal resistivity where fabric weight followed it orderly. $100 \%$ cotton Buldan fabrics indicated the lowest thermal absorptivity with warmth feeling. Fabric weight was observed as a considerable parameter for the warmcool feeling of fabrics. It was observed that fabrics' cool feeling increased as the fabric thickness increased. Apart from early literature findings, it was also observed that fabrics which have the lowest twist ratio revealed the highest thermal resistivity resulting with the coolest feeling. It may be suggested to conduct further detailed studies about this contrasting result.

Experimental results showed that fabric thickness and fabric weight were the major parameters influencing the fabric air permeability. Moreover, yarn twist was the considerable factor among those with high fabric weight and thickness. It was observed that fabrics with the lowest weight and thickness indicated the highest air permeability while fabrics with the highest weight and thickness revealed similar air permeability. This result was attributed to high twisting ratios of the yarns from the fabric. Lowest air permeability was found among the fabrics made of yarns with the lowest twist. As a general evaluation, cotton/Tencel blended Buldan fabrics revealed similar thermal comfort properties with $100 \%$ cotton Buldan fabrics. However, the lowest thermal absorptivity was obtained from $100 \%$ cotton Buldan fabrics which are expected to provide warmth feeling.

\section{REFERENCES}

[1] Özer, L.M., A Regional woven fabric "buldan cloth", fabrics touching Anatolia, $7^{\text {th }}$ International Istanbul Textile Conference, 2016, 21-23 March, Istanbul-Turkey, 199-202

[2] Uğurlu, A., Uğurlu, S.S., Buldan cloth as the region's cultural identity, In: Buldan Symposium Proceedings Book, Pamukkale University, 2006, 23-24 November, Denizli, 275-280

[3] Utkun, E., Gündoğan, M.A., An application study aimed at improving the usage area of buldan weaving, In: Ejovoc (Electronic Journal of Vocational Colleges), 2014, 4, 4, 73-78

[4] Sezgin, Ş., Buldan weavings and Handworks, I. National Handcraft Symposium, Dokuz Eylül Universitesi Yayınları, İzmir, 1981, 321-333

[5] Erdoğan, Z., Buldan Dokumacıığı ve İlçede Üretilen Düz Dokumaların Bazı Özellikleri Üzerine Bir Araştırma, Ankara Üniversitesi Fen Bilimleri Enstitüsü, Ev Ekonomisi Anabilim Dalı Doktora Tezi, Ankara, 1996

[6] Öztürk, F., Çoruh, E., Buldan Dokumalarının Moda Endüstrisinde Kullanılabilirliğine Yönelik Bir Uygulama, In: Tekstil ve Mühendis Dergisi, 2013, 20, 91, 27-34

[7] Kahvecioğlu, H., An Investigation about some Mechanical Properties of Buldan Weavings, In: Buldan Symposium, Pamukkale, Denizli, 2006

[8] Atalayer, G., Twisted Cloth-Bükülü Bez (Bürümcük), In: Journal of Türkiyemiz, 1987, 53, 29-30 
[9] Özdemir, E.K., The effect of Industrialization in Textile Industry on Local Fabric Production: Denizli (Buldan-Tavas), In: Journal of Akdeniz Art, 2012, 4, 7, 137-140

[10] Öner, E., A Research about Comfort Properties of Woven Fabrics, Pamukkale University, Institute of Natural Applied Sciences, M.Sc. Thesis in Textile Engineering, 2008, 94

[11] Yoon, H.N., Buckley, A., Thermal Transport of Textiles for Comfort, In: Textile Research Journal,1984, 34, 3, 54-58

[12] Demir, Ö., The Effect to Fabric Comfort Properties used of Luxicool Fiber, Pamukkale University, Institute of Natural Applied Sciences, Textile Engineering, Msc Thesis, Denizli, 2016

[13] Havenith, G., The Interaction of Clothing and Thermoregulation, In: Exogenous Dermatology, 2002, 1, 5, 221-230

[14] Greyson, M., Encyclopedia of Composite Materials and Components, Wiley \& Songs, USA, 1983, 697

[15] Kawabata, S., Niwa, M., Sakaguchi, H., Applications to Product Design and Process Control, In: The Third Japan/Australia Joint Symposium on Objective Measurement, Osaka, Japan, 1985, 96-109

[16] Özdil, N., Marmaralı, A., Kretzschmar, S., Effect of Yarn Properties on Thermal Comfort of Knitted Fabrics, In: International Journal of Thermal Sciences, 2007, 46, 1318-1322

[17] Cimili, S., Nergis, B.U., Candan, C., Özdemir, M., A Comparative Study of Some Comfort-related Properties of Socks of Different Fiber Types, In: Textile Research Journal, 2009, 80, 10, 948-957

[18] Das, B., Das, A., Kothari, V. K., Fanguiero, R., Araujo, M., Moisture Transmission through Textiles Part I: Processes Involved In Moisture Transmission and The Factors At Play, In: AUTEX Research Journal, 2007, 7, 2, 100-110

[19] Das, B., Das, A., Kothari, V.K., Fanguiero, R., Araujo, M., Moisture Transmission through Textiles Part II: Evaluation Methods and Mathematical Modelling, In: AUTEX Research Journal, 2007, 7, 3, 194-216

[20] Turan, R.B., Okur, A., Air Permeability in Fabrics, In: Tekstil ve Mühendis, 2015, 72, 16-25

[21] Frydrych, I., Dziworska, G., Bilska, J., Comparative Analysis of the Thermal Insulation Properties of fabrics made of Neutral and Man-Made Cellulose Fibres, In: Fibres \& Textiles in Eastern Europe, 2002, 10, 4, 40-44

[22] Oğlakçıoglu, N., Marmaralı, A., Thermal Properties of some Knitted Structures, In: Fibres \& Textiles in Eastern Europe, 2007, 15, 5-6, 64-65

[23] Hes, L., Fundaments of Design of Fabrics and Garments with Demanded Thermophysiological Comfort, In: Textile Congress, Liberec, 2001, 94-95

[24] Uzun, M., An Investigation of Conventional and Compact Ring Spinning Techniques Effect on Tensile and Thermal Comfort Properties of Woven Fabrics, In: Marmara University Journal of Institute of Applied Natural Sciences, 2013, 25, 3, 91-99

[25] Mecheels, J.H., Umbach, K.H.,The Psychometric Ranges of Clothing Systems, Clothing Comfort: Interactions of Thermal, Ventilation, Construction and Assessment Factors, Ann Arbor, MI: Ann Arbor Science Publishers 1977, 133-166

[26] Oğlakçıoğlu, N., Marmaralı, A., Effect of Regenerated Cellulose Fibers on the Thermal Comfort Properties of ompression Scoks, In: The Journal of Textiles and Engineer, 2008, 17, 77

[27] EN ISO 9237, Textiles, determination of the permeability of fabrics to air, International Organization for Standardization, Geneva, 1995

[28] Havenith, G., Interaction of clothing and thermoregulation, In: Exogenous Dermatology, 2002, 1, 5, 221-230

Authors:

\section{MINE AKGUN ${ }^{1}$, GIZEM KARAKAN GUNAYDIN², AYÇA GÜRARDA ${ }^{1}$ ERHAN KENAN ÇEVEN ${ }^{1}$}

${ }^{1}$ Bursa Uludag University, Faculty of Engineering, Textile Engineering Department, Bursa, Turkey email: akgunm@uludag.edu.tr, aycagur@uludag.edu.tr, rceven@uludag.edu.tr

2Pamukkale University, Buldan Vocational School, Fashion \& Design Programme, 20400, Buldan, Denizli, Turkey

Corresponding author:

GIZEM KARAKAN GÜNAYDIN

e-mail: ggunaydin@pau.edu.tr 


\title{
Narrative designed proposals of mechanical or electro-mechanical optimization to the current wheelchairs used by people with severe locomotion restraints
}

\author{
DOI: $10.35530 / I T .071 .04 .1830$
}

AURA SPINU

VLADIMIR CARDEI

VALERIU AVRAMESCU

IOANA ANDONE

AURELIA ROMILA

AURELIAN ANGHELESCU
MIHAIL TIBERIU AVRAMESCU ANA-MARIA BUMBEA

ELENA VALENTINA IONESCU

VLAD CIOBANU

CRISTINA DAIA

GELU ONOSE

\section{ABSTRACT - REZUMAT}

Narrative designed proposals of mechanical or electro-mechanical optimization to the current wheelchairs used by people with severe locomotion restraints

The field of mechatronic/robotic wearable exoskeletons, specifically those designated for assistance/rehabilitation in severe neuro-/locomotor disabling conditions in the lower limbs, is considered to have a great potential for radically changing the harsh condition of wheelchairs users, by restoring their defining human traits: bipedal, vertical, stance and gait. But even the most advanced such complex devices, are not yet effectively able to largely replace the wheelchairs. Therefore, until the overall complete wheelchairs' substitutes, will meet, in this purpose, all the necessary related requirements, we have determined, and accordingly, designed - from a double perspective: of professionals and of (a) consumer - a series of necessary and rather accessible/feasible, consistent: mechanical and electro-mechanical improvements, to the current common type of wheelchairs, in order to improve the global functioning, autonomy and consequently, the quality of life in the needing people, with severe mobility restraints. These, for now, narratively innovative concepts and specifically designed, practical/technological-constructive solutions, target 10 main kinds of beneficial outcomes, i.e. a decalogue and their derivatives to be expected (most of them previously imagined by us but not completely designed until now, two of them already achieved but which need updating and other four entirely new), that could result in an "all-in-one" product paradigm which, to our knowledge, is not available at present. This model of wheelchair we propose is, at the same time, modular, so a certain consumer can purchase/ be offered only his/her own case-specific needed optimization components of it.

Keywords: severe mobility restraints, improved wheelchair, variable geometry, multi-functional rear wheel guards, pliability, modular all-in-one product paradigm

Propuneri și proiectare - narative - pentru optimizare mecanică sau electro-mecanică a fotoliilor rulante actuale, folosite de persoane cu restricții severe de locomoție

Domeniul exoscheletelor mecatronice/robotice purtabile, în special al celor proiectate pentru asistare/recuperare în suferinte neuro-locomotorii sever dizabilitante la membrele inferioare, este considerat a avea un potential de schimbare radicală a condiției utilizatorilor de fotolii rulante, prin restabilirea trăsăturilor umane definitorii: poziția bipedă, postura și mersul verticale. Dar, chiar și cele mai avansate astfel de dispozitive complexe, nu sunt încă efectiv capabile să înlocuiască pe scară largă fotoliile rulante. De aceea, până când substituenți deplini ai fotoliilor rulante vor întruni, în acest scop, toate cerințele necesare conexe, noi am stabilit și, consecutiv, proiectat - dintr-o dublă perspectivă: a profesioniștilor și a consumatorului - o serie de optimizări mecanice sau/și electro-mecanice, consistente, necesare și relativ accesibile/fezabile, pentru fotoliile rulante actuale, cu scopul de a îmbunățăți funcționalitatea globală, autonomia și în consecință, calitatea vieții persoanelor cu restricții severe de locomoție. Aceste - deocamdată narative - concepte inovatoare și soluții practice, tehnologic-constructive special concepute, vizează 10 tipuri principale de rezultate benefice, respectiv, un decalog și derivate ale acestuia (cele mai multe dintre ele imaginate de noi anterior, dar fără a fi fost complet proiectate până acum, două dintre ele deja realizate, dar care necesită actualizări, și alte patru complet noi), din care ar putea rezulta un produs în paradigmă "toate în-unul", care, după cunoștința noastră, nu este disponibil în prezent. Acest model de fotoliu rulant pe care îl propunem este, în același timp, modular, astfel încât un utilizator poate să achiziționeze/să-i fie oferite doar componentele de optimizare specifice nevoilor proprii ale cazului respectiv.

Cuvinte-cheie: restricții severe de locomoție, fotoliu rulant îmbunătățitoptimizat, geometrie variabilă, apărătoare roți spate multi-funcționale, paradigma produsului modular "toate în-unul"

\section{INTRODUCTION. BACKGROUND}

As detailed elsewhere [1], including the personal experience of one of this article's main author - both an academic physician of Physical and Rehabilitation Medicine (with special focus on NeuroRehabilitation) and respectively, of Gerontology and Geriatrics, but 
also a chronic, physically incapacitated person, wheelchair user - the impossibility to perform two connected fundamental, defining features of the human physiology, i.e. bipedal: (ortho)static posture and gait, represents the severest disability and handicap [2] that affects - as systematized in the World Health Organization (WHO)'s (newer) paradigm regarding human functioning - all the levels within this describing framework, namely "Body functions and structures", "Activities and Participation", resulting in "Impairments... problems in body function or structure such as significant deviation or loss" -, "Activity limitations... difficulties an individual may have in executing activities" - and "Participation restrictions... problems an individual may experience in the involvement in life situations" [3]. This seriously lowers, at the same time, the quality of life in people with such kind of - no matter the cause - marked invalidity.

Consequently, the cartoon "of a person in the wheelchair is the worldwide used symbol for handicap" [4].

On the other hand, there is evidence for persons who cannot achieve/keep vertical, bipedal, stance and/or gait - at least for post spinal cord injury (SCI) paraplegics who have wheelchairs manually propelled "as their primary means of mobility" [5] - that "their ability to perform manual wheelchair skills is associated with higher community participation and life satisfaction. Factors contributing to low success rates need to be investigated and interventions to improve these rates are needed" [5].

It should also be noted that a task/skill with the lowest success rate - included among the items of the Wheelchair Skills Test Questionnaire (WST-Q), too [6] - is the rise/flight "ascending (19.6\%) ... 15-cm curb" [5].

In older people there is an augmented necessity to avail "mobility support" [7] wheeled mobility equipment (WME). "From 1990-2005, WME use grew 5\% per year, while mobility difficulty declined among the elderly and remained steady among working-age persons. This contrast suggests a reduction in the unmet need for WME" [8]. For instance, in individuals aged $\geq 50$ years, the need for wheelchairs in order to overcome mobility - especially of ambulation kind difficulties/reduction and hence, participation restrictions [9], becomes higher than in adolescents and younger adults; specifically: $\geq 85$ year old wheelchair users are over than 20 times more numerous than those between 12-44 years of age [9]. Additionally, we have to mention the practically global, alert rhythm of demographic ageing [10-12] prone to already generate - and in the future, more and more - elderly, including with mobility problems, thus also an enhanced number of wheelchairs users. As ageing consists of progressive, overall, functional decline - even possibly of frailty [13], especially in the "oldest-old" [14] - obviously their skills/capabilities regarding the use of wheelchairs become lessened; so, this is a supplementary but consistent rationale for aiming at the manufacture of better wheelchairs, which could provide enhanced compensatory assistance as the consumer's general endurance and dedicated abilities - as mentioned above - fade.

Despite important progresses made, especially in less than a (last) decade, in the field of mechatronic wearable exoskeletons - for bionic bipedal standing and walking, too - the eagerly awaited completely available, from all essential points of view: perfectly safe, "effectively wearable" (easy to be attached to and put in service - obviously, preferable - by the user, and concerning the respective man-machine interaction, as well), enough energy storage/provision, "appropriateness for long time use" - including "in community" -, acceptable aspect when equipping/observed together with the consumer, truly affordable/cost-effective [4] such a kind of very complex, fully functional device, is still to come.

Considering, on the one hand, the assertion: “... unfortunately, data on the prevalence of $\mathrm{SCl}$ are sparse. Currently there are no reliable global or regional estimates of all-cause $\mathrm{SCl}$ prevalence" and on the other, a very approximate prevalence average worldwide, based on the estimation data from 6 countries, for traumatic and 2 countries for non-traumatic SCl - both in [15] - we have calculated, largely, that currently, at an actual world population of around 7.6 billion people [16], there could be about 11.000 .000 post $\mathrm{SCl}$ survivors, and as over $90 \%$ of (only) post traumatic SCl are wheelchair users [17], and if we added other categories of related consumers, within a global approximation, such persons in need would be, more or less, $1 \%$ of a population [18]. This also entails the obvious health-assistive and socio-economic importance (regarding the support to the clients for participation within the family and the extended environment - even for employment, if medically possible - but also the market for these extremely important mobility aids/assistive devices) of the subject matter we approach. Thereby, the wheelchair is considered to be "one of the most commonly used assistive devices for enhancing personal mobility, which is a precondition for enjoying human rights and living in dignity and assists people with disabilities to become more productive members of their communities... step towards inclusion and participation in society" [18].

"In 2012, it was estimated that worldwide over 185 million people use a wheelchair daily, and almost 20 percent of the world's population is now aged over 65 years, and that is forecast to exceed 35 percent by 2050" [19]. So, it is important to develop advanced devices for assisting the post $\mathrm{SCl}$ patients or other categories of inpatients that need such a device for achieving some degree of autonomy and thus being more active and increasing their QoL.

Based, including on the older but valuable document [18] (our narratively innovative proposals for technical/functional-assistive optimizations to the actual wheelchairs considered knowledge from it, too, including for their modular construct - see further), the $\mathrm{WHO}$, coagulating and leading a large panel of 
stakeholders worldwide, has initiated in 2013 and launched in 2014, a comprehensive international project - through a paradigm shift: the "Assistive Health Technology" and "Assistive Health Products" concepts, split from the more general design of "assistive products and technology" [20]. A dedicated - and pragmatic - task/effect aimed and supported, including by this initiative endorsed by the $\mathrm{WHO}$, is the achievement of the WHO Priority Assistive Products List (APL) - which raises "awareness among the public, mobilizes resources and stimulates competition" and "provides guidance for procurement and reimbursement policies, including insurance coverage" [16, 21]: among 100 of such devices, wheelchairs hold seven places (between the first 7-13 positions), i.e. - aside lower limb orthoses - the largest framing [22].

Under these circumstances, as the individuals who cannot stand and/or walk, mandatorily need mobility in their everyday life, until it will be truly possible for wheelchairs to be replaced by the above-mentioned robotic wearable type of advanced orthoses, the former might benefit of some - basically mechanical/ electro-mechanical, hopefully not expensive, but we consider, very useful - improvements, which we shall describe in this article.

In the specific literature, there is a series of guidelines (one of them approved by the WHO's Guidelines Review Committee on 16 April [18] that refer to an adequate manual wheelchair. In order to be functional and appropriate for the user, the wheelchair should enable outdoor advancing and it should "provide proper fit and postural support; is safe and durable; is available in the country and can be obtained and maintained and service sustained in the country at an affordable cost" [23].

The above-mentioned guidelines are important for conceiving such devices as regards design, fabric and provision [18].

Disability, being actually an important and difficult multidisciplinary problem including at the social level, it is recommended for any country to have a national strategy regarding wheelchair standards as a basis and further, to merge such an endeavor with the local capabilities of architectural, conveyance and medical kinds for ensuring, thus, effective inclusion and consequent acceptable quality of life for the respective consumers [18].

We also consider the five major goals of prescribing a wheelchair for people with severe neuro/locomotor disabilities, as already mentioned in the literature [24]: "to maximize the client's independent mobility; prevent/minimize deformity or injury; maximize independent functioning; project a healthy, vital, attractive 'body image'; and minimize short- and long-term costs" [25].

It must be specified that we first started to conceive such optimizations more than ten years ago. We have then implemented them partially by means of certain technical additions to a standard wheelchair, and reported [26], together with mentioning the supplementary improvements we intended, at that time, to design.

\section{METHOD AND ITS RATIONALE}

Considering these ideas of ours, for optimization (and other newer - including enlarging, more recently, our panel of specialists/co-authors - being at present, still in the design stage) we reckon it would be beneficial to make them known, as they haven't yet been published, even as narrative technical proposals. Thus (at least some of them) might eventually reach a long delayed - but we still strongly, constructively and fairly consider them useful - translational course, for the benefit of so many wheelchair users. The following narrative optimization proposal that will be presented below, result of a Delphi kind method professionals in the medical and engineering/technical fields - with important consisting in the fact that one of the main authors is not only a professional in the field but also a chronic complete paraplegic, and therefore, a permanent wheelchair user.

Accordingly, the target population that may benefit from the improved mechanical/electro-mechanical facilities in the current wheelchairs, we propose, has severe ambulation restrictions caused, in principal, by neurologic conditions: thoracic, lumbar/-sacral and/or lower (C7 and downwards - thus mostly paraplegics) cervical, post $\mathrm{SCl}$ - traumatic and/or nontraumatic - conditions, poly-neuropathies in the lower limbs, dangerous (as falling risk) balance disorders, but also by muscle-skeletal ones (thigh bilateral amputations and/or multiple invalidating lesions in appendicular bearing joints - with poor/no availability, for different reasons, for endo-prosthetic/s approach), and/or by cardio-/respiratory failure, respectively by severe morbid obesity; this entails adequate bilateral force and dexterity in the upper limbs, including with an acceptable/functional capability to handle transmission of driving voluntary commands, to the mechanical and/or electro-mechanical effecter structures of the wheelchair.

Further, in the elapsed above-mentioned period, improvements concordant with those we have conceived, have been fulfilled regarding making lighter wheelchairs within other researches and consequently, newer models of wheelchairs, already in use [27-28].

In a recent literature review about step-climbing power wheelchairs [29], it is mentioned that some of the current wheelchairs that can climb on steps are still in research, so "these devices represent a variety of approaches to the tasks of climbing a single step or continuous stairs, including leg-wheel hybrid systems, spider wheels, additional structures for lifting, and crawler tractors".

Although the prototype tests that were found in this research were made in some appropriate and controlled conditions, the results were not comparable between articles and two of these reports [30-31] 
which were analyzed in the above-mentioned article had important clinical studies but their results weren't very convincing and couldn't be used for a comparative evaluation of the efficacy of the devices by other researchers.

The conclusion is that, with only one such device existing on the market, what is needed first of all is "to develop a well-specified driving evaluation" which can mention the most common inconveniences encountered by wheelchair users and also to increase the accessibility of these devices on different kinds of land with bumps, to "make their mechanisms and sensors reliable" and to produce a device at a good price and high quality [29].

\section{RESULTS}

In order to achieve the improvement goals within an afore-mentioned all-in-one product paradigm of a narratively innovative upgraded model of wheelchairs, we herein describe further, in tabular form, exemplified by suggestive figures, our related decalogue and their derivatives of optimization proposals. Specifically, in a preliminary brief enumerative synthesis these are (in an all-in-one integrative design):

- propelled by his/her own upper limbs and electrically - with optimization of the batteries' positioning - powered by motors placed on the big wheels;

- (novelty item) improved way of manual - or electromechanically initiated - propelling (through and over each big wheel - but without contacting it - tilting guard, thus resulting, on the one hand, in the possibility to spare push rings and of narrowing, at the same time, the overall width of the wheelchair and on the other hand, to avoid the hands accidentally touching the wheels - which can be dirty);

- (novelty item) better ground bumps/kerbs negotiation (through an installed facility for about 30 degrees elevation of the front/small wheels enabling to climb/stride on unevenness of the ground of maximum $20 \mathrm{~cm}$;

- (correlated) with another one for instant anti-overturning when back tilting;

- (novelty item) an additional braking capability that would operate only when the manual or electrical power to ascend the wheelchair is insufficient compared to the gravitational force of a too sharp ground profile;

- adjustable fittings to stabilize the user's (paralyzed) feet within the footrest(s) - in order to avoid their displacement due to shattering actions caused by advancing on ground asperities;

- damper elements added;

- assisted verticalization - but at the same time, with pliability/ foldability keeping - at variable angles (up to almost 90 degrees - done and controlled/modulated mechanically, or better, electrically - constructive capability including proneness to prophylaxis of pressure sores in the buttocks region: an important issue encountered in the wheelchair, long-term, daily use);
- (novelty item) easy/prompt manual adjusting of the wheelchair's backrest verticality with +/- 30-40 degrees (depending on the necessity to maintain the client's center of gravity when descending or respectively, climbing more abrupt slopes);

- possibility to access and/or turn in tight spaces like some elevators/lifts, corridors - including through antero-posterior variable geometry (anteroposterior slide of the support for the feet, connected with their possibility to be moved in both frontal and sagittal (not only backward but also front lifted) plans.

All these improvements proposed are intended, in sum, to avoid significantly enhancing its total weight (about $15 \mathrm{~kg}$ ), so that our multimodal all-in-one model of wheelchair can remain available (with its pliability/foldability kept) for transportation in a car trunk, too.

Regarding pliability/foldability - invented over 80 years ago [32] - and which is a basic capability, from the essential point of view of a daily comfortable wheelchair's handling: aside a functional related specific mechanical constructive solution (most frequent of a X-shaped/"folding cross-brace frame" [33] design, type), a sine qua non underlying contributive component is the avail of a textile material, mandatory to be used in both, the bottom/ hammock and the backrest, usually with "sling upholstery" [33] - especially in order to avoid pressure sores and to make a better and more protected/fitted position of the customer in the device - that may consist of "foam and combinations of foam/gel or foam/air" [34] of such kind of a wheelchair. This must have, in a balanced manner, enough hardness - "nonsag materials" [35] - and flexibility, and at the same time, it needs to be lasting/resilient, non-toxic, non-allergenic, waterproof, flame retardant and easy to be cleaned. Commonly used synthetic fabrics, in this purpose, are polyvinyl chloride (PVC), polyester, nylon.

It should be mentioned that our about $15 \mathrm{~kg}$ weight wheelchair will have all the upgrades stated above, including detachable leg rest - although, similar wheelchairs, without any improvements, found in the marketplace weight also 15-27.21 kg (33-60 lbs) [36-37]. Carbon fiber wheelchairs with no detachable footrest could weight, indeed, less than $10 \mathrm{~kg}$ but our improvement proposal does not fit to this design.

Although some of these advancements are already being applied in the motorized wheelchair constructions, we will use them together with our original concepts for the narratively intended optimization of wheelchairs.

\section{SYSTEMATIZATION OF THE MULTIFUNCTIONAL MODULAR ALL-IN-ONE TYPE OF WHEELCHAIR OPTIMIZATIONS}

To the constructive variants of the wheelchair mentioned in table 1, a number of original optimization solutions (some of them patent pending) will be applied, according to the main 10 beneficial outcomes 
mentioned above, solutions which target constructive and functional upgrading of the wheelchairs, and increasing the autonomy degree of their users (tables 2 and 3 ).

CONSTRUCTIVE VARIANTS OF WHEELCHAIRS, SUBJECT TO OUR IMPROVEMENT PROPOSALS

A wheelchair with foldable bearing structure and manual actuation: the basic modular variant A (figures 1,2 and 3 )

B wheelchair with foldable bearing structure and electric actuation: the structure is based on variant $A$, to which the specific modules are added (figures 3 and 4 )

C wheelchair with bearing structure allowing for verticalization, with mechanical actuation: basic modular variant $\mathrm{C}$ includes also modules of variant A (figures 5 and 6)

D wheelchair with the bearing structure allowing for verticalization, with electric actuation: the structure is based on variant $C$ and includes the specific modules of variant $B$ (figures 6 and 7 )

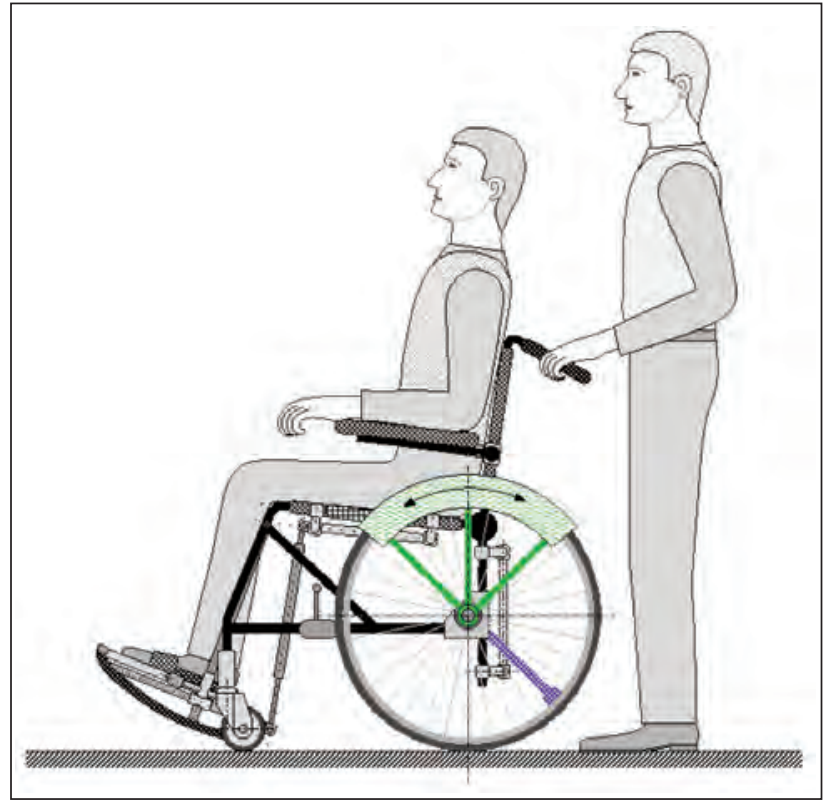

a

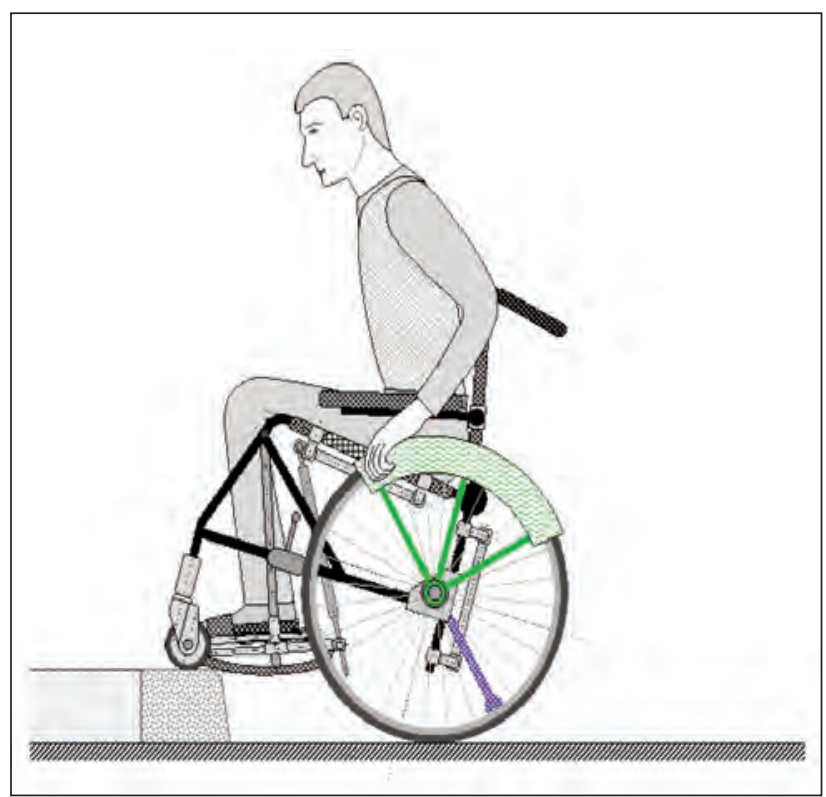

c

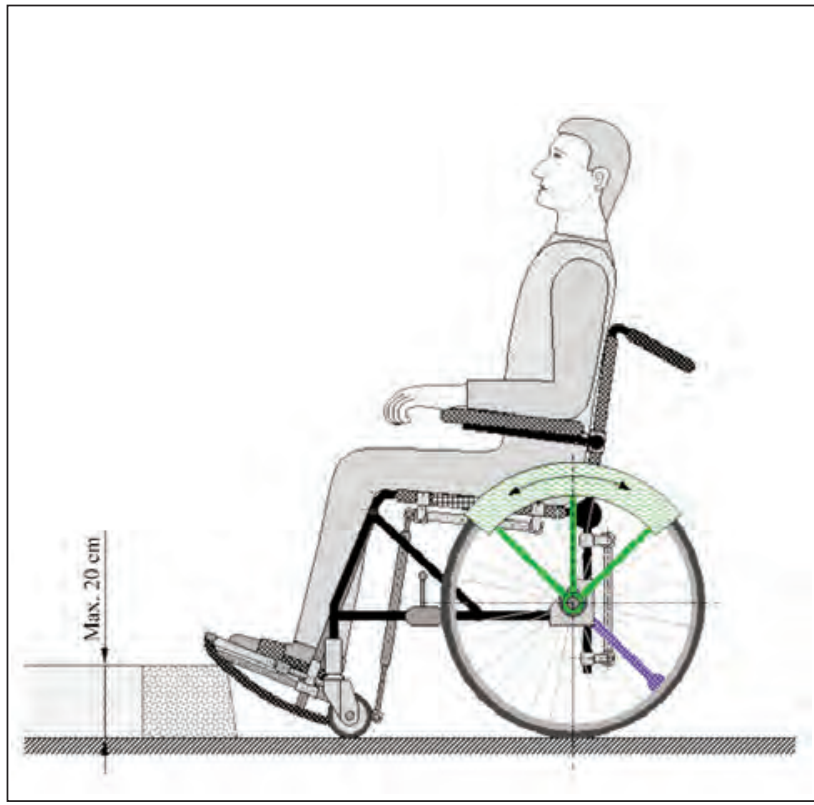

b

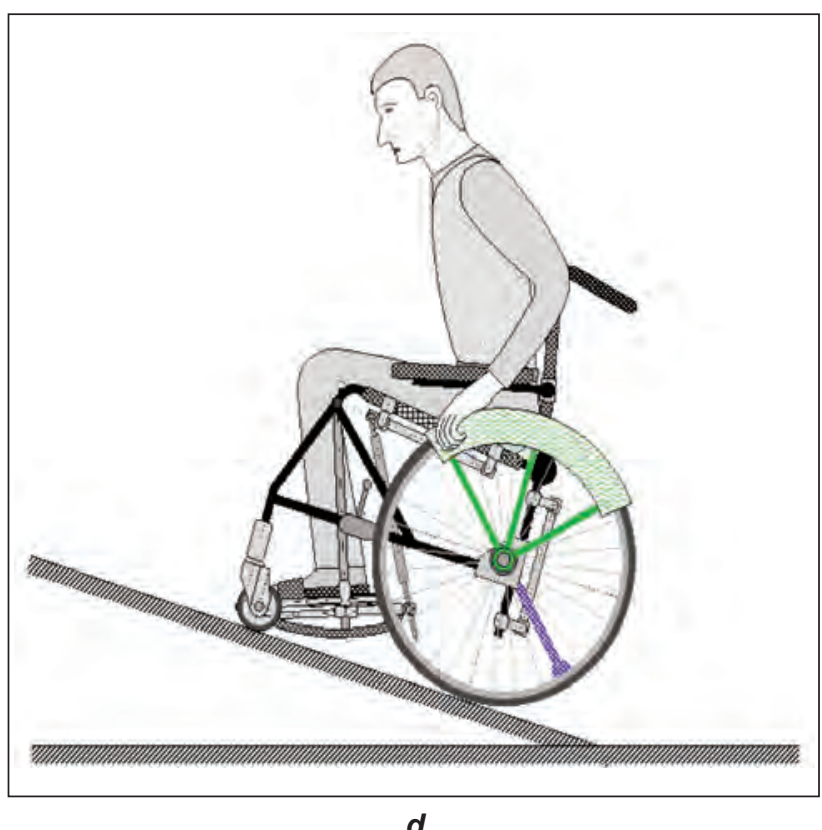

d

Fig. 1. Situations encountered when using a/ the wheelchair: $a$ - patient sitting in the wheelchair; $b$ - patient in the wheelchair next to a sidewalk; $c$ - climbing the sidewalk; $d$ - climbing a slop 


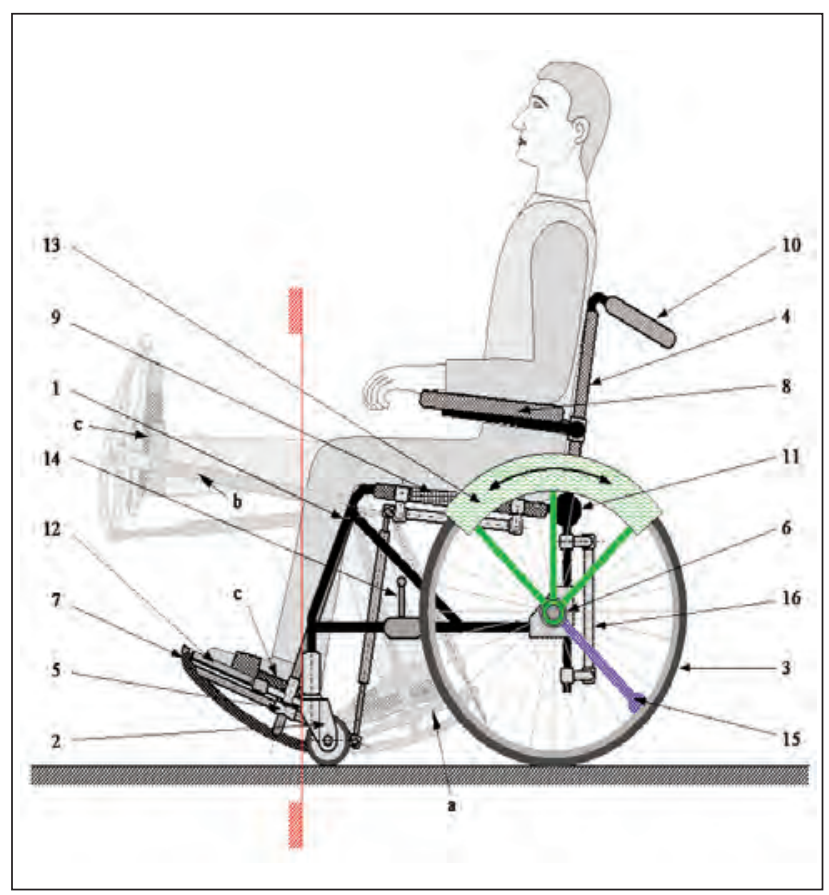

Fig. 2. Component of the manually driven wheelchair: 1 - basic folding frame; 2 - swivel front wheel; 3 - rear wheel; 4 - seat with adjustable backrest; 5 - adjustable feet support; 6 - anti-overturning device; 7 - bumper climbing device; 8 - folding adjustable armrests; 9 - command block; 10 - assist/propelling handles from the attendant; 11 - backrest-angle tilting device; 12 - adjustable feet stabilization system; 13 - multifunctional: protective and propelling guard; 14 - mechanical brake with manual actuation enabling counteract gravitational backward movement; 15 - auxiliary/optional anti-overturning facility; 16 - folding/de-folding mechanism of the wheelchair; a - the fully retracted position of the adjustable feet support; $b$ - constructive facility that enables for intermittently posturing the user's feet in cvasi horizontal position - prone to an improved anti-gravitational circulation, of venous-lymphatic drainage in the lower limbs; $c$ - velcro standard support for the heel region

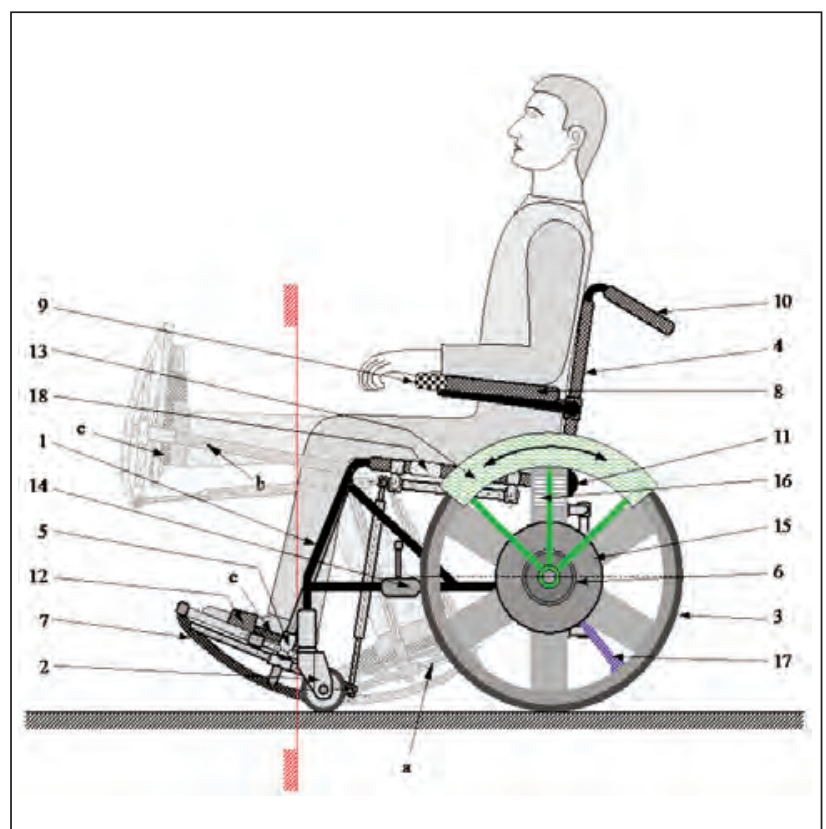

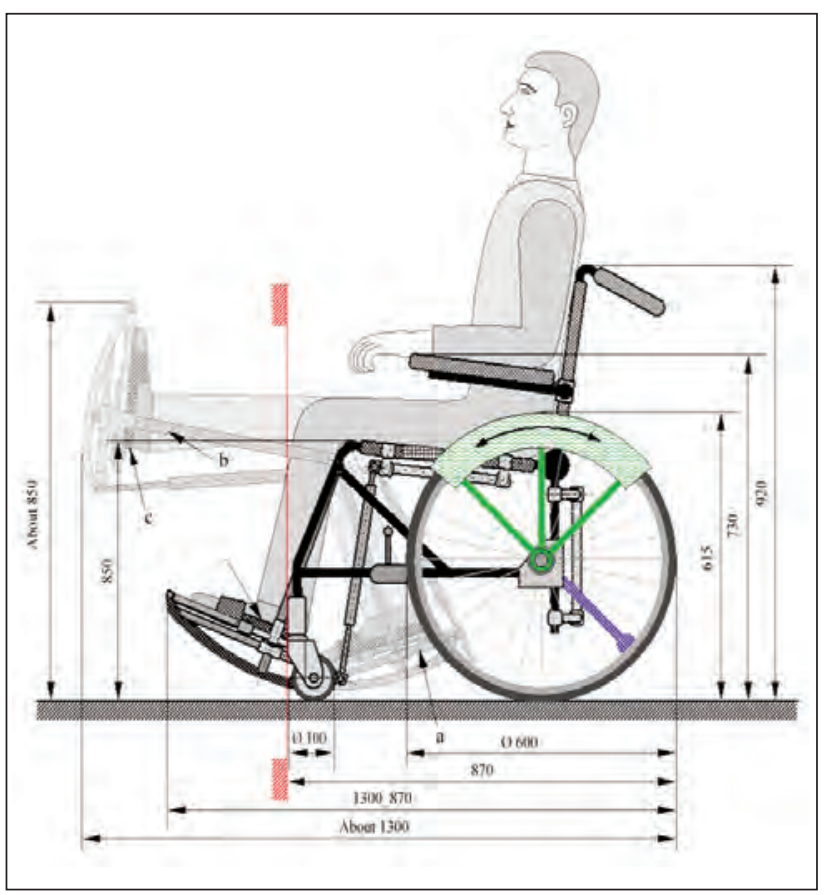

Fig. 3. Overall dimensions of the wheelchair - variants $A$ and $B$ (dimensions in $\mathrm{mm}$ ): $\mathrm{a}$ - The fully retracted position of the adjustable feet support; $b$ - Constructive facility that enables for intermittently posturing the user's feet in cvasi horizontal position - prone to an improved anti-gravitational circulation, of venous-lymphatic drainage in the lower limbs; c - Velcro standard support for the heel region

Fig. 4. Component of the electrically driven wheelchair: 1 - basic folding frame; 2 - swivel front wheel; 3 - motorized rear wheel; 4 - seat with adjustable backrest; 5 - adjustable feet support; 6 - anti-overturning device; 7 - bumper climbing device; 8 - folding adjustable armrests; 9 - electrical control block; 10 - assist/propelling handles from the attendant; 11 - backrerst-angle tilting device; 12 - adjustable feet stabilization system; 13 - multifunctional: protective and propelling guard; $14-$ mechanical brake with manual actuation enabling to counteract gravitational backward movement; 15 - rotary actuator; 16 - accumulator battery; 17 - auxiliary/optional anti-overturning facility; 18 - command facility for adjusting the backrest-angle tilting device; $a$ - the fully retracted position of the adjustable feet support; $b$-constructive facility that enables for intermittently posturing the user's feet in cvasi horizontal position - prone to an improved anti-gravitational circulation, of venous-lymphatic drainage in the lower limbs; c - velcro standard support for the heel region 


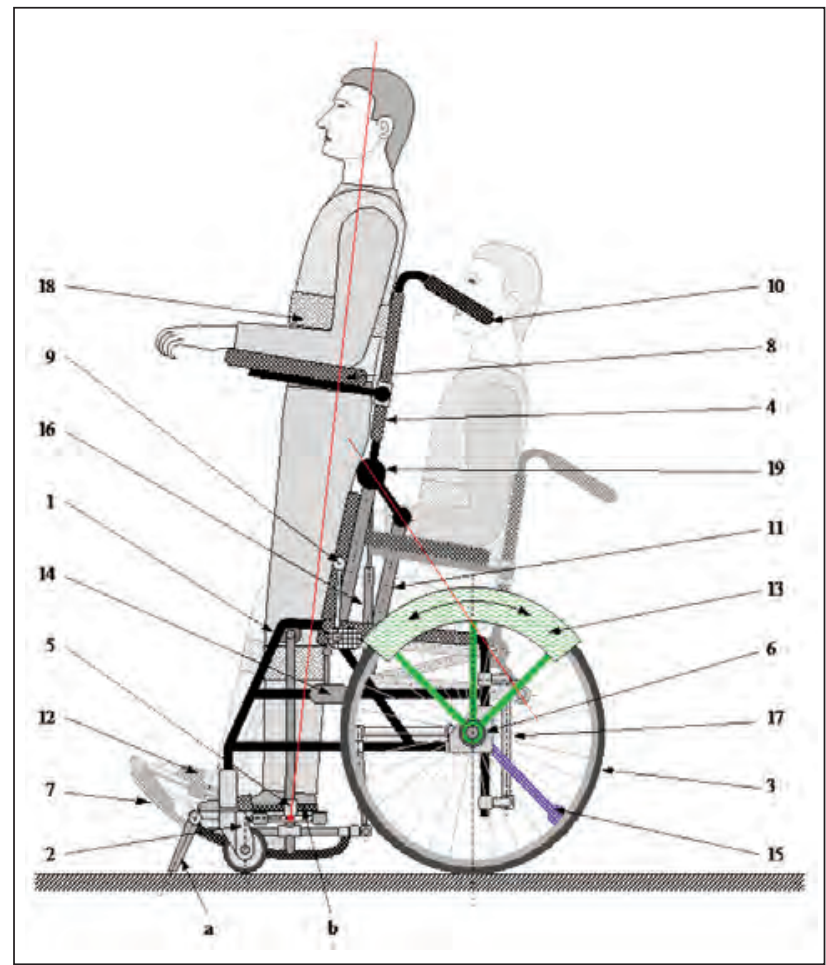

Fig. 5. Component of the wheelchair with manual actuation that allows verticalization: 1 - basic folding frame; 2 - swivel front wheel; 3 - rear wheel; 4 - seat with adjustable backrest; 5 - adjustable foot support; 6 anti-fall autoblocker device; 7 - bumper climbing device; 8 - folding adjustable armrests; 9 - seat actuation lever; 10 - assisting handles by attendant; 11 - seat-upright mechanism; 12 - feet support and stabilization system; 13 - protective device; 14 - mechanical brake with manual actuation; 15 - auxiliary/optional facility anti-fall; 16 - user weight compensation device; 17 - folding/ defolding mechanism of the wheelchair; 18 - support belts (thorax and knee) of the user; $a$ - folding stand for securing the vertical position of the user; $b$ - velcro standard support for the heel region
Fig. 7. Component of the wheelchair with electric actuation that allows verticalization: 1 - basic folding frame; 2 - swivel front wheel; 3 - motorized rear wheel; 4 - seat with adjustable backrest; 5 - adjustable feet support; 6 - anti-overturning device; 7 - bumper climbing device; 8 - folding adjustable armrests; 9 - seat verticalization lever; 10 - assist/propelling handles from the attendant; 11 - seat verticalization mechanism; 12 adjustable feet stabilization system; 13 - multifunctional: protective and propelling guard; $14-$ mechanical brake with manual actuation enabling to counteract gravitational backward movement; 15 - auxiliary/optional antioverturning facility; 16 - user's weight compensation device; 17 - folding/de-folding mechanism of the wheelchair; 18 - support belts for user's thorax and knees; 19 - rotary actuator; 20 - accumulator battery; 21 - electrical control block; 22 - backrerst-angle tilting device; $a$ - folding stand for securing the vertical position of the user; $b$ - velcro standard support for the heel region

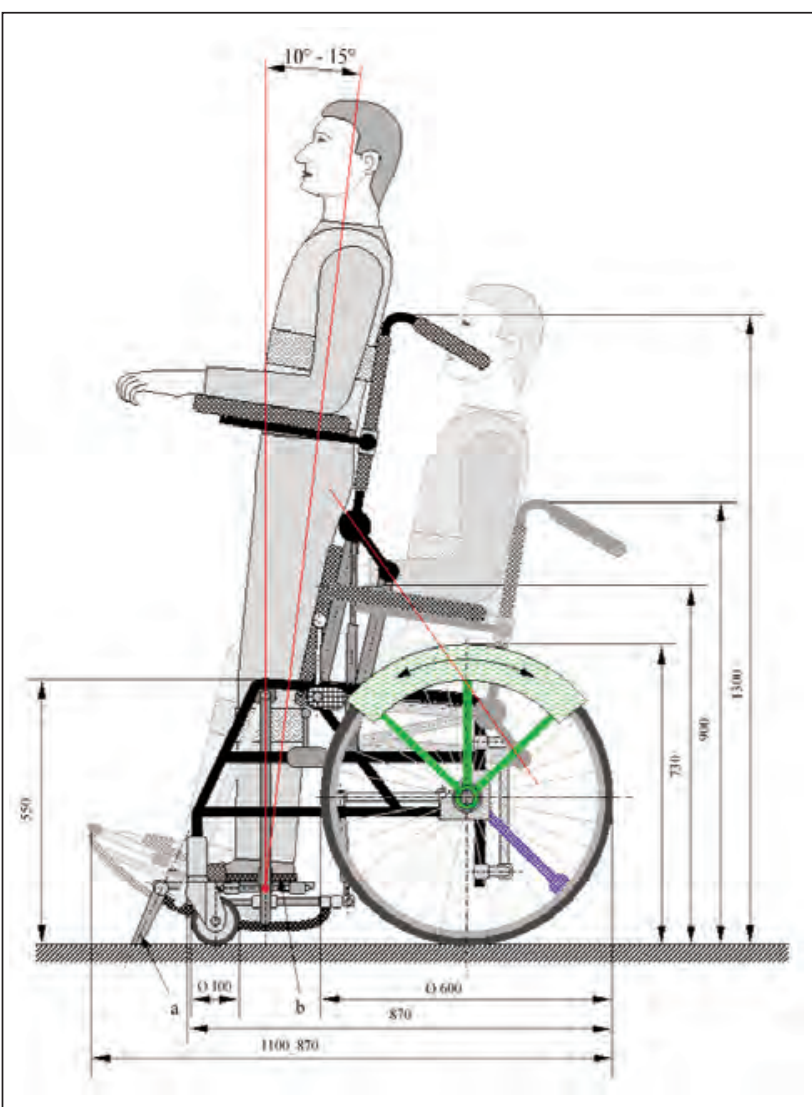

Fig. 6. Overall dimensions of the wheelchair - variants $C$ and $\mathrm{D}$ (dimensions in $\mathrm{mm}$ ): $a$ - folding stand for securing the vertical position of the user; $b$ - velcro standard support for the heel region 
ORIGINAL CONTRIBUTIONS FOR OPTIMIZING WHEELCHAIRS IN ORDER TO INCREASE THE AUTONOMY DEGREE OF THE USERS

\begin{tabular}{|c|c|c|c|c|c|}
\hline \multirow{2}{*}{ No. } & \multirow{2}{*}{ Description of the proposed optimizations and facilities } & \multicolumn{4}{|c|}{ Variant* } \\
\hline & & A & B & C & D \\
\hline 1 & 2 & 3 & 4 & 5 & 6 \\
\hline 1 & $\begin{array}{l}\text { The lightweight bearing structures with about** } 15(\mathrm{~kg}) \text { weight } \\
\text { Aluminum alloy pipes and carbon fiber composite materials will be used both, } \\
\text { for the bearing structure and for the motor wheels, with integrated actuators } \\
\text { and accumulators }\end{array}$ & $\geq 12 \mathrm{~kg}$ & $\geq 14 \mathrm{~kg}$ & $\geq 13 \mathrm{~kg}$ & $\geq 15 \mathrm{~kg}$ \\
\hline 2 & $\begin{array}{l}\text { The modular foldable bearing structure (see specifications in table } 3 \text { ) } \\
\text { Bearing structures of variants, A, B, C and D are composed of the following } \\
\text { mechanically interconnected common modules: } \\
\text { - Basic frame, foldable and adjustable } \\
\text { - Swivel front wheels } \\
\text { - Rear wheels } \\
\text { - Multifunctional wheel guards on the upper } 1 / 4 \text { of rear wheels } \\
\text { - Seat/Stand support platform with adjustable backrest } \\
\text { - Adjustable feet (not only heels - as currently in the standard wheelchairs) } \\
\text { support with stabilization facility consisting of an extended hook-and- } \\
\text { loop (Velcro) straps/loops system } \\
\text { - Anti-overturning facilities } \\
\text { - Bumper compensation device } \\
\text { - Folding adjustable armrests } \\
\text { - Damper elements } \\
\text { - Constructive facility that enables for intermittently posturing the user's } \\
\text { feet in cvasi horizontal position - prone to an improved anti-gravitational } \\
\text { circulation, of venous-lymphatic drainage in the lower limbs, coupled, } \\
\text { within a same swivel kind of system, with the facility of sliding backwards of } \\
\text { feet support (see below) } \\
\text { - Assist/propel handles from the attendant bearing structures of variants, } \\
\text { A, B, C and D are foldable, so the wheelchair can be put in the trunk of } \\
\text { a car }\end{array}$ & A & $\mathrm{B}$ & $\mathrm{C}$ & $\mathrm{D}$ \\
\hline 3 & $\begin{array}{l}\text { Adjustment of the backrest position to various specific situations of use: } \\
+1-30 . .40 \text { degrees } \\
\text { Equipment of the wheelchair backrest with subassemblies and options to allow } \\
\text { the suitability of its position to specific situations shown in use, by its tilting } \\
\text { variation, performed quickly and easily by the user }\end{array}$ & A & B & - & - \\
\hline 4 & $\begin{array}{l}\text { Sliding possibility in the sagittal plan of the feet support } \\
\text { The feet support will be provided with sliding possibility in the sagittal plan for } \\
\text { the legs up to the user's knees, in the same plan, in order to allow access into } \\
\text { elevators or other narrow antero-posterior spaces }\end{array}$ & A & B & - & - \\
\hline 5 & $\begin{array}{l}\text { The bearing structure allowing the lifting of the assisted person } \\
\text { In order to facilitate the pro-gravitational urinary flow and stools, as well as to } \\
\text { allow the beneficiary touching of some objects at a superior height than } \\
\text { conferred by the wheelchair (shelves, bookcases/cabinets); verticalization } \\
\text { capability does not exclude foldability }\end{array}$ & - & - & C & $D$ \\
\hline 6 & $\begin{array}{l}\text { Anti-overturning facilities of the rear tilt trend/risk of a wheelchair } \\
\text { Ensures the rear wheels' blockage in relation to the bearing structure, when the } \\
\text { weight assigned to the front wheels decreases under a certain amount } \\
\text { (consequent to the acceleration necessary to be induced to the wheelchair), for } \\
\text { "overlapping" bumps, as well as the referral, at the hub level of each rear } \\
\text { wheel, of the appearance of an angular acceleration over a safety preset limit } \\
\text { (on the principle of automatic mechanical locking of the car seatbelt) }\end{array}$ & $A$ & B & C & $D$ \\
\hline 7 & $\begin{array}{l}\text { Multifunctional wheels guards on upper } 1 / 4 \text { of the rear wheels } \\
\text { To protect the user's hands from soiling during self-propelling also for manual } \\
\text { direct actuation at the wheel's hub level, while achieving through eliminating } \\
\text { the external maneuvering circles, to reduce the lateral gauge of the wheelchair, } \\
\text { prone to facilitate access to narrow spaces }\end{array}$ & $A$ & B & C & $D$ \\
\hline 8 & $\begin{array}{l}\text { Brakes } \\
\text { Two constructive solutions are foreseen: on the one hand, equipping the } \\
\text { wheelchair with a hand-operated mechanical system for each rear wheel (with } \\
\text { the succession: unbraked, braked both ways, braked on running back) and on }\end{array}$ & $A$ & B & C & $D$ \\
\hline
\end{tabular}




\begin{tabular}{|c|c|c|c|c|c|}
\hline 1 & 2 & 3 & 4 & 5 & 6 \\
\hline & $\begin{array}{l}\text { the other hand, for electrically powered wheelchairs - with a system that allows } \\
\text { simultaneous transmission, on both rear wheels, of all braking commands, given } \\
\text { with one hand, from a single command center, the location of the brake command } \\
\text { being placed in the seat support structure area under the user's thighs, in a } \\
\text { convenient position for handling. } \\
\text { Additional braking capability that would be operated only when the manual or } \\
\text { electrical power to ascend the wheelchair is insufficient compared to the } \\
\text { gravitational force of a too sharp ground profile; propelling again the wheels } \\
\text { guards, the user will be thus able to continue climbing with his/her wheelchair the } \\
\text { respective slope (if its sharpness does not exceed the above mentioned } \\
\text { anti-gravity - manual or electrical - force) }\end{array}$ & & & & \\
\hline 9 & $\begin{array}{l}\text { Folding adjustable armrests } \\
\text { Folding/tilting armrests are provided, with adjustable angles and lengths by tele- } \\
\text { scoping, indexable, elements that will also serve to operate other optional devices } \\
\text { of the wheelchair (adjustable tilting backrest device) }\end{array}$ & $A$ & B & C & $D$ \\
\hline 10 & $\begin{array}{l}\text { Pockets for operating with fingers all the electrical commands } \\
\text { Provision of areas in spaces at the lateral edges of the seating support structure, } \\
\text { anterior front of the rear wheels, for operating with fingers of some levers or } \\
\text { command buttons }\end{array}$ & - & B & - & D \\
\hline 11 & $\begin{array}{l}\text { High efficiency motors and accumulators mounted in the rear wheels' struc- } \\
\text { ture } \\
\text { Rotative actuators with a high yield and the accumulator's battery mounted in the } \\
\text { rear wheels' structure must ensure a functioning autonomy of minimum } 3 \text { hours }\end{array}$ & - & $B$ & - & $D$ \\
\hline 12 & $\begin{array}{l}\text { Possibility for the wheelchair to climb on sidewalk curbs of maximum } 20 \mathrm{~cm} \\
\text { by self-propelling } \\
\text { The feet support is equipped with the possibility to run over an obstacle with the } \\
\text { height of maximum } 20 \mathrm{~cm} \text {, by self-propelling (figures } 1,2,4,5 \text { and } 7 \text { ) }\end{array}$ & $A$ & $B$ & - & - \\
\hline 13 & $\begin{array}{l}\text { Endowment with damping elements that take on shocks when moving } \\
\text { Isolation of the user from the shocks that occur when the wheelchair moves is } \\
\text { done either by mounting dampers for each wheel and/or by insulating the seat } \\
\text { structure of the basic pliable frame }\end{array}$ & - & $B$ & C & D \\
\hline 14 & $\begin{array}{l}\text { Adjustable feet (not only heels - as currently in the standard wheelchairs) sup- } \\
\text { port with stabilization facility consisting of of an extended hook-and-loop } \\
\text { (Velcro) straps/ loops system }\end{array}$ & $A$ & B & C & D \\
\hline
\end{tabular}

* The significance of the variants is presented in table 1.

** Information values without the weight of the optional electro-mechanical components

ADDITIONAL CONSTRUCTIVE SPECIFICATIONS OF THE WHEELCHAIR'S MODULAR STRUCTURE, REGARDING SUGGESTED OPTIMIZATIONS AND RELATED FACILITIES

\begin{tabular}{|c|l|}
\hline No. & \multicolumn{1}{|c|}{ Additional constructive specifications of suggested optimizations and related facilities } \\
\hline 1 & \multicolumn{1}{|c|}{2} \\
\hline 1 & $\begin{array}{l}\text { Basic pliable frame } \\
\text { Frame folding capacity is based on a precise rectilinear guiding mechanism, characterized by the existence of only } \\
\text { rotating couplings, that gives the mechanical structure a much larger spatial rigidity, a much smaller folding/ } \\
\text { unfolding effort of the users and the possibility for a simpler maintenance } \\
\text { To compensate for uneven grounds, the folding frame will be provided, in certain joints, with elastic insertion, } \\
\text { constructive solution that will reduce the rigidity of the folding frame in order to diminish its mechanical stress and } \\
\text { mitigate the shocks incurred by the user }\end{array}$ \\
\hline 2 & $\begin{array}{l}\text { Swivel front wheels } \\
\text { They are each provided with a system for detracting the tendency of loss of contact with the ground, by } \\
\text { automatically tracking the force with which the respective swivel wheel is loaded } \\
\text { When both front wheels contact the ground with forces under a certain prescribed value, the protection system } \\
\text { against the wheelchair roll-over/over-turning is triggered. This system consists of two anti-overturning telescopic } \\
\text { rods, located on each side of the rear wheels and/or by blocking the rear wheel hubs automatically (on the } \\
\text { principle of the automatic mechanical locking of the car seatbelt) when a predefined value of rotation acceleration } \\
\text { is exceeded }\end{array}$ \\
\hline
\end{tabular}




\begin{tabular}{|c|l|}
\hline 1 & \multicolumn{1}{|c|}{2} \\
\hline 3 & $\begin{array}{l}\text { Bumper climbing device } \\
\text { The adjustable feet support will be provided with the possibility of rotation in the sagittal plan relative to the user's } \\
\text { knees position, with circular rod (on its inferior edge located in the extreme lateral inferior side of the adjustable } \\
\text { supports), in order to climb over bumps of maximum } 20 \mathrm{~cm} ; \\
\text { The circular rolling range of the adjustable supports is situated at a height from the ground which is smaller than } \\
\text { the wheelchair's pivotal wheel rotating radius (figures } 1,2,4,5 \text { and } 7 \text { ) }\end{array}$ \\
\hline 4 & $\begin{array}{l}\text { Assist handles } \\
\text { For the protection of both the wheelchair user and the attendant, assist handles are provided with the possibility } \\
\text { to control braking when descending on inclined surfaces; this also prevents going back while climbing slopes }\end{array}$ \\
\hline
\end{tabular}

\section{CONCLUSIONS}

The existence of optional modules, some of them common for all constructive variants of wheelchairs and compatible with them, allows the user to optimize gradually, in time, his/her own wheelchair, depending on additional requirements and financial possibilities. For the producers of the four variants of wheelchairs, manufacturing costs would be lower due to the endowment of the constructive variants with modules, common manufacturing materials, and technologies.

We consider that this proposed system of wheelchairs - having a modular structure with many elements common to all the four variants - allows a specific user to purchase only the components necessary for a specific optimization in his/her wheelchair; thus, the price of any variant cannot exceed, significantly, the price of similar contemporary wheelchairs, although it offers, in one product, many additional functions given by the additional optimizations and facilities proposed.

Considering these ideas of ours, at optimization and other newer ones which are, at present, still in the design stage (prone to be patented) - we reckon it would be beneficial to make them known, even as narratively technical proposals.

Although they might be too numerous, the technical solutions for optimization we have proposed are, in our opinion, beneficial and their - hopefully soon - materialization would probably contribute to an overall better functioning and living for the wheelchair users.

\section{AUTHOR CONTRIBUTIONS}

All authors listed have equally contributed to this work and approved it for publication.

\section{ACKNOWLEDGMENTS}

We herein mention (chronologically) the names of all the partners who, along time, have viewed the original ideas we have conceived for optimizing the mechanical or electro-mechanical assistive performances of current wheelchairs, and thank them for their related consideration: Catalin Orasanu, Stefan Tudorel Craciunoiu, Cristian Grozea, Florin Popescu, Loredana Paun, Raluca Nita, Steffi Keller, Hannah Wolff, Ivo Haulsen, Manuel Schiewe, Anca Sanda Mihaescu, Bogdan Ungur, Oliver Lemon, Simon Keizer, Marius Nicolae Popescu, Radu Tudor Ionescu, Cristina Cristalli, Giacomo Angione, Luca Lattanzi, Kari-Jouko Räihä, Howell Istance, Stephen Ackland.

This work has received the approval of the Ethics Commission of the: Teaching Emergency Hospital "Bagdasar-Arseni" (TEHBA), in Bucharest (no. 42493/ 19.12.2018), Teaching County Emergency Hospital "Sf. Apostol Andrei", in Galati (no. 27390/12.12.2019), The University of Medicine and Pharmacy (no. 137/20.12.2019), in Craiova and Balnear and Rehabilitation Sanatorium Techirghiol (no. 62/12.12.2019), Romania.

\section{REFERENCES}

[1] Onose, G., Tratat de Neurochirurgie/ Textbook of Neurosurgery, chap. Rehabilitation in conditions following spinal cord injuries, Ed. Medicala, 2011, 2, ISBN: 978-973-39-0720-6

[2] WHO, International Classification of Impairments, Disabilities, and Handicaps - IC-IDH - A manual of classification relating to the consequences of disease, World Health Organization Geneva, 1980

[3] WHO, International Classification of Functioning Disability and Health (ICF), World Health Organization Geneva, 2001

[4] Onose, G., Cardei, V., Craciunoiu, S., Avramescu, V., Opris, I., Lebedev, M.A., et al., Mechatronic Wearable Exoskeletons for Bionic Bipedal Standing and Walking: A New Synthetic Approach, In: Front Neurosci, 2016, 10, 343, https://doi.org/10.3389/fnins.2016.00343, PubMed Central:PMC5040717, PubMed: 23372025

[5] Hosseini, S.M., Oyster, M.L., Kirby, R.L., Harrington, A.L., Boninger, M.L., Manual wheelchair skills capacity predicts quality of life and community integration in persons with spinal cord injury, In: Arch Phys Med Rehabil, 2012, 93, 2237-2243, https://doi.org/10.1016/j.apmr.2012.05.021, PubMed: 22684049

[6] Kirby, R.L., Smith, C., Parker, K., MacLeod, D.A., McAllister, M., Wheelchair Skills Test Questionnaire (WST-Q) Version 4.2 Manual, Dalhousie University, Halifax, Nova Scotia, Canada, 2013

[7] Shields, M., Use of wheelchairs and other mobility support devices, In: Health Rep, 2004, 15, 37-41, PubMed: 15208888 
[8] LaPlante, M.P., Kaye, H.S., Demographics and trends in wheeled mobility equipment use and accessibility in the community, In: Assist Technol, 2010, 22, 3-17, https://doi.org/10.1080/10400430903501413, PubMed: 20402043

[9] Sakakibara, B.M., Miller, W.C., Routhier, F., Backman, C.L., Eng, J.J., Association between self-efficacy and participation in community-dwelling manual wheelchair users aged 50 years or older, In: Phys Ther, 2014, 94, 664-674, https://doi.org/10.2522/ptj.20130308, PubMed Central: PMC4016678, PubMed: 15878473

[10] Bravo, J., Hertog, S., Kamiya, Y., Lai, M.S., World Population Ageing, Tech. rep., United Nations, Department of Economic and Social Affairs, Population Division, 2015

[11] De Beer, J., Future trends in life expectancies in the European Union - Research Note, Tech. rep., Netherlands Interdisciplinary Demographic Institute for European Commission, Directorate-General "Employment, Social Affairs and Equal Opportunities", Unit E1 - Social and Demographic Analysis, 2006

[12] Chen, G., Chan, C.K., Guo, Z., Yu, H., A review of lower extremity assistive robotic exoskeletons in rehabilitation therapy, In: Crit Rev Biomed Eng, 2013, 41, 343-363, PubMed: 24941413

[13] Onose, G., Ancane, G., Capisizu, A., Haras, M., Rostowska, O., Sorensen, K., et al., Doctors and older patients' health literacy on functional decline and frailty related to ageing - data from Romania and Latvia, In: Biophilia, 2016, 41-41, https://doi.org/10.14813/ibra.2016.41

[14] Encyclopedia of Population. Oldest old 2003, Dataset, Available at: https://www.encyclopedia.com/social sciences/ encyclopedias-almanacs-transcripts-and-maps/oldest-old [Accessed on March 2020]

[15] Bickenbach, J., International Perspectives on Spinal Cord Injury, In: World Health Organization (WHO) - The International Spinal Cord Society (ISCOS), 2013

[16] WHO, Priority Assistive Products List (APL), Available at: http://www.who.int/phi/implementation/assistive_ technology/global_survey-apl/en/ [Accessed on March 2020]

[17] Biering-Sørensen, F., Hansen, R.B., Biering-Sørensen, J., Mobility aids and transport possibilities 10-45 years after spinal cord injury, In: Spinal Cord, 2004, 42, 699-706, https://doi.org/10.1038/sj.sc.3101649, PubMed: 15289807

[18] Armstrong, W., Borg, J., Krizack, M., Lindsley, A., Mines, K., Pearlman, J., et al., Guidelines on the provision of manual wheelchairs in less-resourced settings, World Health Organization, 2008

[19] Frisoli, A., Solazzi, M., Loconsole, C., Barsotti, M., New generation emerging technologies for neurorehabilitation and motor assistance, In: Acta Myol, 2016, 35, 141-144, PubMed Central: PMC5416742, PubMed: 22208122

[20] WHO, Global Cooperation on Assistive Health Technology (GATE), 2014

[21] WHO, Global Cooperation on Assistive Technology, Available at: http://www.who.int/phi/implementation/assistive technology/phi_gate/en/[Accessed on March 2020]

[22] WHO, WHO Priority Assistive Products List (APL). Global Survey, Available at: http://www.who.int/phi/ implementation/assistive_technology/english_apl_global_survey_for_web.pdf [Accessed on March 2020]

[23] Sheldon, S., Jacobs, N.A., Report of a Consensus Conference on Wheelchairs for Developing Countries, World Health Organization Geneva, Bangalore, India, 2006

[24] Brittel, C., Krusen's handbook of physical medicine and rehabilitation (Saunders; 4 edition), chap. Wheelchair prescription, 1990, 584-563

[25] Duffield, S., Wheelchair Prescription in the Western Region of the Eastern Cape, Master's thesis, Faculty of Medicine at Stellenbosch University, 2013

[26] Andone, I., Onose, G., Avramescu, V., Cardei, V., Orasanu, C., Assumptions and conceptual contributions to improve the global assistive performance of actual wheelchairs, in order to enhance the user's autonomy and quality of life, In: Journal of Medicine and Life V Special issue, 2012, 86-94

[27] https://www.southwestmedical.com/Wheelchairs/LightweightWheelchairs/Quickie-Breezy-600-LightweightWheelchair/ 2403p [Accessed on March 2020]

[28] http://www.panthera.se/en/produkt_x.html [Accessed on March 2020]

[29] Sundaram, S. A., Wang, H., Ding, D., Cooper, R. A., Step-Climbing Power Wheelchairs: A Literature Review, In: Top Spinal Cord Inj Rehabil, 2017, 23, 98-109, https://doi.org/10.1310/sci2302-98, PubMed Central: PMC5672886, PubMed: 25276796

[30] Uustal, H., Minkel, J.L., Study of the Independence IBOT 3000 Mobility System: an innovative power mobility device, during use in community environments, In: Arch Phys Med Rehabil, 2004, 85, 2002-2010, PubMed: 15605340

[31] Laffont, I., Guillon, B., Fermanian, C., Pouillot, S., Even-Schneider, A., Boyer, F., et al., Evaluation of a stair-climbing power wheelchair in 25 people with tetraplegia, In: Arch Phys Med Rehabil, 2008, 89, 1958-1964, https://doi.org/10.1016/j.apmr.2008.03.008, PubMed: 18929024

[32] Everest, H.A., Jennings, H.C., US Patent 2,095,411, 1937, Available at: https://patentimages.storage. googleapis.com/7e/4e/8a/fb8c3969f9461b/US2095411.pdf [Accessed on March 2020]

[33] Worobey, L.A., Rigot., S.K., Boninger, M.L., Wheelchairs - In: Frontera, W.R. (Ed.-in chief), DeLisa, J.A. (Ed. Emeritus), Basford, J.R., et al., (Eds), DeLisa's Physical Medicine \& Rehabilitation, Principles and Practice, Sixth Edition, Chpt. 58, Philadelphia, USA: Woltres Kluwer, Copyright@2020 Woltres Kluwer

[34] DiGiovine, C.P., Koontz, A., Berner, T., Kim, D.J., Schmeler, M., Wheelchairs and Seating Systems, In: Cifu, D.X. (Ed): Braddom's Physical Medicine \& Rehabilitation, Fifth Edition, Elsevier, Chpt. 14, 2016

[35] Bedbroock, G., The Care and Management of Spinal Cord Injuries, Chpt. 8. Nursing Management (Care of the Skin - Prevention of Pressure Sores), Springer-Verlag, New York heidelberg Berlin, 1981, 89

[36] https://www.quirumed.com/en/folding-light-wheelchair-aluminium.html\#product-info [Accessed on March 2020]

[37] https://www.1800wheelchair.com [Accessed on March 2020] 
AURA SPINU ${ }^{1}$, VLADIMIR CARDEI ${ }^{2}$, VALERIU AVRAMESCU² ${ }^{2}$ IOANA ANDONE ${ }^{1,3}$, AURELIA ROMILA $^{4,5}$, AURELIAN ANGHELESCU ${ }^{1,3}$, MIHAIL TIBERIU AVRAMESCU6 ${ }^{6}$, ANA-MARIA BUMBEA ${ }^{7,8}$, ELENA VALENTINA IONESCU ${ }^{9,10}$, VLAD CIOBANU ${ }^{11}$, CRISTINA DAIA ${ }^{1,3}$, GELU ONOSE ${ }^{1,3}$

${ }^{1}$ Teaching Emergency Hospital "Bagdasar-Arseni”, in Bucharest, Romania ${ }^{2}$ Research and Technological Design Institute for Machines Construction, Bucharest, Romania ${ }^{3}$ University of Medicine and Pharmacy "Carol Davila", Bucharest, Romania 4"Dunarea de Jos" University of Galati, Romania

${ }^{5}$ Teaching County Emergency Hospital "Sf Apostol Andrei”, Galati, Romania ${ }^{6}$ Deutsche Bank, Bucharest, Romania ${ }^{7}$ University of Medicine and Pharmacy, Craiova, Romania

${ }^{8}$ Neurorehabilitation Department, Clinical Neuropsyhiatry Hospital, Craiova, Romania

${ }^{9}$ Ovidius University of Constanta, The Faculty of Medicine, Romania

${ }^{10}$ Balnear and Rehabilitation Sanatorium Techirghiol, Romania

${ }^{11}$ Computer Science Department, Politehnica University of Bucharest, Bucharest, Romania

\section{Corresponding author:}

\section{GELU ONOSE}

e-mail: geluonose@gmail.com 


\title{
Textile wing fabric for emergency response UAS
}

\author{
DOI: 10.35530/IT.071.04.1762
}

\section{ABSTRACT - REZUMAT}

\section{Textile wing fabric for emergency response UAS}

The fabrics used to manufacture parachutes and paragliders must have several specific characteristics: the mass of fabric per unit of surface must be low while the other physical-mechanical characteristics (the axial breaking strength load, the relative and absolute elongation, the tear resistance of the fabric and the assemblies, air permeability) must have high values. The paper deals with the analysis of qualitative aspects of several parachute fabrics that are used as a baseline in the development of a novel fabric. The results of experiments have materialized in statistical data, diagrams and graphs and their interpretation leads to the determination of the fabric variant that best meets the requirements of the destination. The destination is a patent pending inflatable wing design that utilizes a single skin construction and solid reinforcements in the sewing for shape stability. It is worth noting that the experimental results were compared with values indicated in specific international testing norms.

Keywords: parachute, paraglider, single sail, technical textile, fabric testing

\section{Țesătura aripii unui UAS pentru situații de urgență}

Țesăturile utilizate în realizarea parașutelor și parapantelor trebuie să aibă câteva caracteristici specifice: masa țesăturii pe unitatea de suprafață trebuie să fie scăzută, în timp ce celelalte caracteristici fizico-mecanice (rezistența la rupere axială, alungirea relativă și absolută, rezistența la rupere a materialului și a asamblărilor, permeabilitatea la aer) trebuie să înregistreze valori ridicate. Lucrarea tratează analiza aspectelor calitative ale mai multor țesături pentru parașută, care sunt utilizate ca bază în dezvoltarea unei țesături noi. Rezultatele experimentelor s-au materializat în date statistice, diagrame și grafice, iar interpretarea acestora duce la determinarea variantei de țesătură care corespunde cel mai bine cerințelor impuse de domeniul de utilizare. Domeniul de utilizare este o aripă textilă brevetabilă, care utilizează o singură pânză extrados și întărituri solide în asamblare pentru stabilizarea formei. De remarcat că rezultatele experimentale au fost comparate cu valorile indicate în normele internaționale specifice de testare.

Cuvinte-cheie: parașută, parapantă, aripă, textile tehnice, testarea materialului

\section{INTRODUCTION}

The laws of mechanics and aerodynamics apply to the performance and stress analysis of parachute systems. However, the textile fabrics used in parachute construction have distinctly different mechanical and environmental characteristics than metals or composites.

This paper depicts the early phase in the research development for an integrated support system tailored for emergency response actions and remote sensing. In this phase we try to develop a fabric that is tailored for use in the manufacturing process of a paraglider type wing design [1] that utilizes a single skin construction [2] and solid reinforcements in the sewing for shape stability.

In order to achieve this we used as a baseline several commercial fabrics and tried to determine the best combination of yarn, weave and finishing method in order to best suite our paraglider wing.
We mention that this is a preliminary work and is subject to change if the prototype performances will not fall within the projected limits.

\section{MATERIALS AND METHODS}

In order to establish a baseline for the fabric characteristics several readily available fabrics were analysed. The fabrics used in the testing were selected so they cover a wide array of parachute types.

Therefore we selected as material one (S1), a fabric commonly used in paraglider manufacturing. This fabric is a rather heavy fabric having polyurethane and silicone coating for UV protection.

The second material (S2) is a fabric used in most of the Ram-Air parachutes available today. It's a light fabric with polyurethane coating for zero air permeability.

The third material (S3) is a fabric with similar structure as $\mathrm{S} 2$ but without polyurethane coating. This fabric is only calendered and it is commonly referred to as F111 type fabric. This type of fabric has some air 
permeability therefore is mainly used in reserve ramair parachutes or partially on the intrados side of main parachutes.

Testing of the tear resistance of the samples was done on the Tinius Olsen Dynamometer H5KT dynamometer (figure 1). The device is designed to test a wide range of materials (yarns, fabrics, leather) for traction, flexion, and assembly strength (made by sewing, thermofusion etc.).

Further on we extracted yarns from the fabrics in order to determine the yarn characteristics.

In table 1 are listed the test results and methods used for these fabrics.

The values of the structural parameters of the fabrics (air permeability, mass, thickness, etc.) were used in conjunction with the extracted yarn test results to determine the multivariate regression equations in which the independent variables were considered the breaking strengths in warp and weft (figure 2). In this figure on $x$-axis we have the displacement of the clamping device, in $\mathrm{mm}$. We notice a very inconsistent reading, as if the yarn is partially slipping, compared

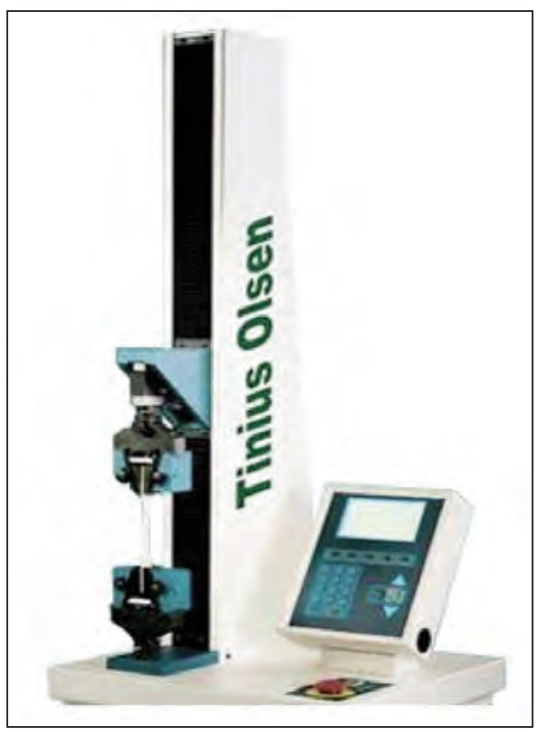

Fig. 1. H5KT dynamometer

with the clean regular Nylon 6.6 yarn. We suspect this to be because of the residual polyurethane coat-

\begin{tabular}{|c|c|c|c|c|c|}
\hline \multicolumn{6}{|c|}{ TEST RESULTS } \\
\hline \multicolumn{2}{|l|}{ Test Name } & s1 & S2 & S3 & Testing method \\
\hline \multicolumn{2}{|l|}{ Fabric mass $\left(\mathrm{g} / \mathrm{m}^{2}\right)$} & 59 & 47 & 40 & SR EN 12127:2003 \\
\hline \multirow[t]{2}{*}{ Yarn count (threads $/ 10 \mathrm{~cm}$ ) } & Warp & 474 & 534 & 532 & \multirow{2}{*}{$\begin{array}{l}\text { SR EN 1049-2:2000; } \\
\text { Method A, B }\end{array}$} \\
\hline & Weft & 432 & 508 & 524 & \\
\hline \multirow[t]{2}{*}{ Yarn linear density (DTex den) } & Warp & $61.8(55.62)$ & $41.2(37.08)$ & $32.6(29.34)$ & \multirow{2}{*}{$\begin{array}{l}\text { SR 6430:2012; } \\
\text { Method A }\end{array}$} \\
\hline & Weft & $69.4(62.46)$ & $46.4(41.76)$ & $32.2(28.98)$ & \\
\hline \multirow[t]{2}{*}{ Yarn breaking strength $(\mathrm{N})$} & Warp & 1.943 & 1.728 & 1.522 & \multirow{4}{*}{$\begin{array}{l}\text { SR EN ISO 2062:2010; } \\
\text { Method B }\end{array}$} \\
\hline & Weft & 1.803 & 1.582 & 1.498 & \\
\hline \multirow[t]{2}{*}{ Yarn elongation at breaking force $(\%)$} & Warp & 25.64 & 38.80 & 27.87 & \\
\hline & Weft & 27.70 & 38.52 & 32.57 & \\
\hline \multirow[t]{2}{*}{ Fabric breaking strength $(\mathrm{N})$} & Warp & 541 & 431 & 450 & \multirow{4}{*}{$\begin{array}{l}\text { SR EN ISO 13934-1: } \\
2013\end{array}$} \\
\hline & Weft & 480 & 412 & 450 & \\
\hline \multirow[t]{2}{*}{ Fabric elongation at breaking force $(\%)$} & Warp & 24.9 & 27.8 & 27.4 & \\
\hline & Weft & 29.1 & 39.3 & 33.9 & \\
\hline \multirow[t]{2}{*}{ Fabric tearing strength $(\mathrm{N})$} & Warp & 20.7 & 66.1 & 35.8 & \multirow{2}{*}{$\begin{array}{l}\text { SR EN ISO 13937-3: } \\
2002\end{array}$} \\
\hline & Weft & 20.7 & 66.3 & 29.2 & \\
\hline \multicolumn{2}{|l|}{ Fabric bursting strength (KPa) } & 370.8 & 334.2 & 334.3 & \multirow{2}{*}{ EN ISO 13938-2/2002 } \\
\hline \multicolumn{2}{|l|}{ Fabric bursting strength (mm) } & 43.2 & 42.2 & 36.6 & \\
\hline \multicolumn{2}{|l|}{ Fabric air permeability $\left(1 / \mathrm{m}^{2} / \mathrm{s}\right)$ at $200 \mathrm{~Pa}$} & 0 & 0 & 11.57 & SR EN ISO 9237:1999 \\
\hline \multicolumn{2}{|l|}{ Raw material } & $100 \% \mathrm{PA}$ & $100 \% \mathrm{PA}$ & $100 \% \mathrm{PA}$ & SR 13231-95 \\
\hline \multicolumn{2}{|l|}{ Coating } & $\begin{array}{c}\text { PU and Silicone } \\
\text { coating }\end{array}$ & PU coating & Calendered & SR ISO 1833-95 \\
\hline \multicolumn{2}{|l|}{ Link type } & Double-ripstop & Ripstop & Ripstop & - \\
\hline \multicolumn{2}{|l|}{ Fabric image } & & & & - \\
\hline
\end{tabular}




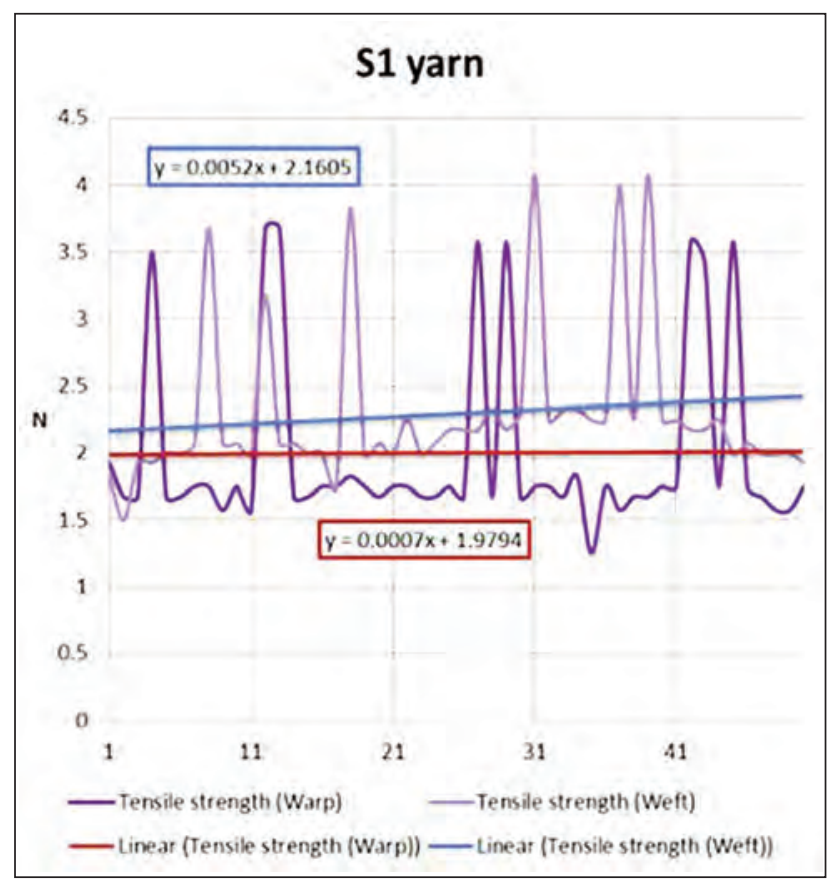

a

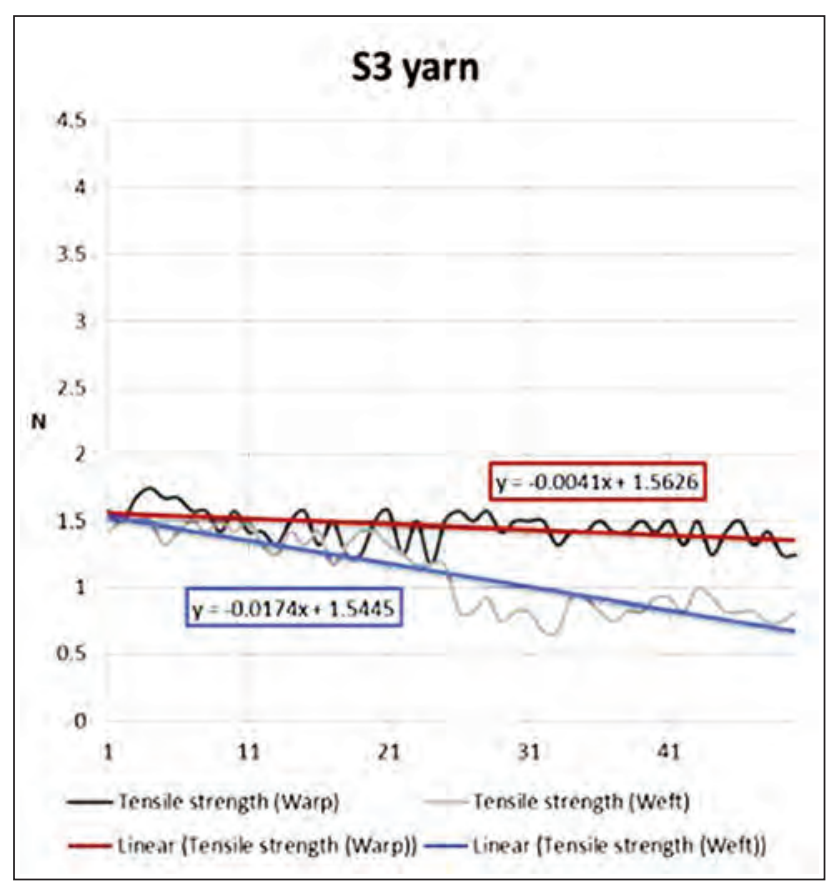

$\boldsymbol{C}$
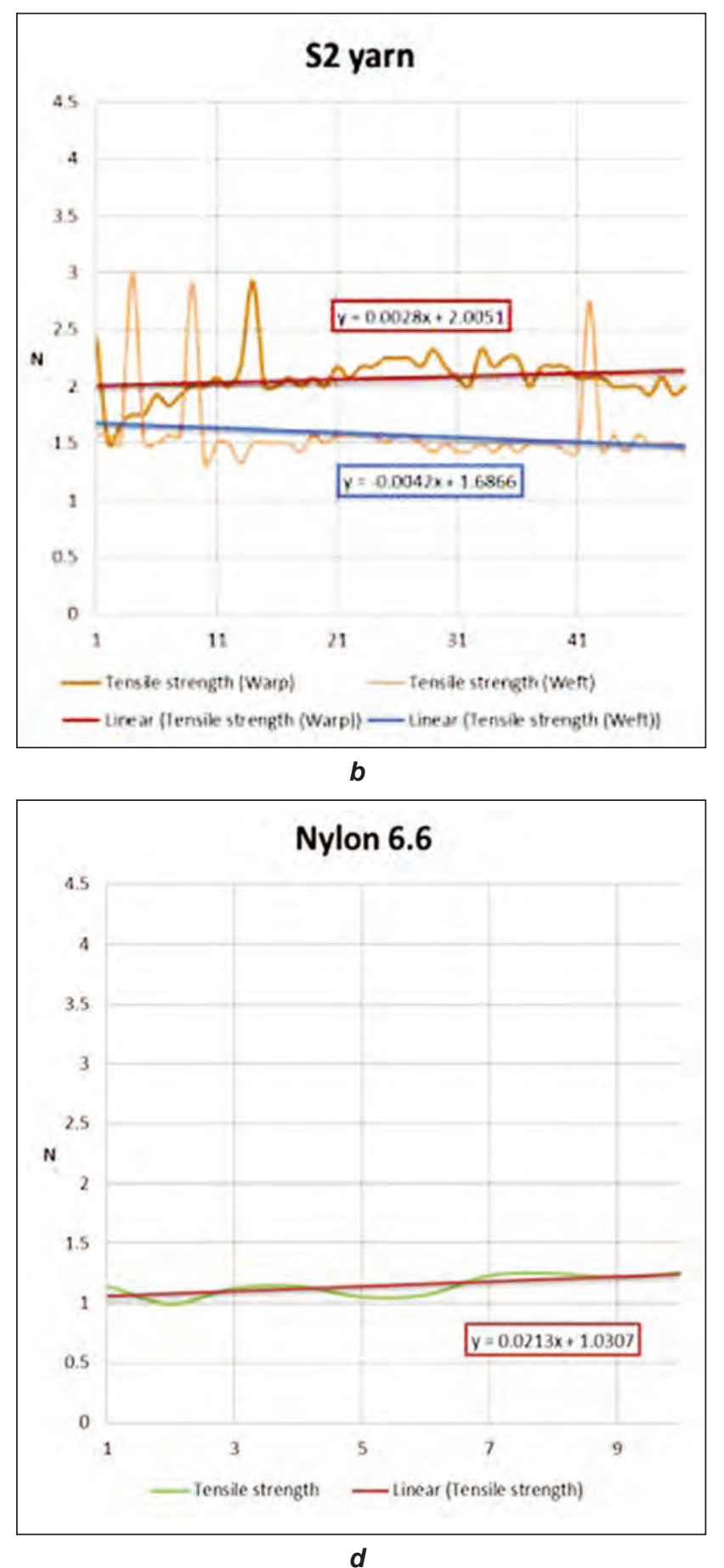

Fig. 2: Breaking strength and trend line for each analysed yarn: $a-\mathrm{S} 1$ yarn; $b-\mathrm{S} 2$ yarn; $c-\mathrm{S} 3$ yarn; $d-\mathrm{Nylon} 6.6$

ing present on the extracted yarns. S3 sample, that was not coated, had smaller reading spikes. A statistical smoothing of the readings puts the breaking strength of the extracted yarns roughly on a value that is double than that of the regular Nylon 6.6 yarn. This is the tell-tale sign that we are dealing with HT Nylon 6.6 yarns. At the time of the testing we did not have stocked HT Nylon 6.6 to make a direct comparison.

\section{RESULTS AND DISCUSSION}

Further on we can assess the strength transfer coefficient [4] given mathematically as:

$$
C=\frac{T f_{2}}{T f_{1}}
$$

where $T f_{1}$ is yarn tenacity before its integration in fabric expressed in N/Tex calculated with the equation:

$$
T f_{1}=\frac{F_{b k g(t)}}{T e x}
$$

$\mathrm{Tf}_{2}$ is theoretical yarn tenacity after its integration in woven structure, including the influence of the weave structure/finishing treatments and is expressed also in $\mathrm{N} / \mathrm{Tex}$ :

$$
T f_{2}=\frac{F_{b k g(t)}}{P \times b \times T e x}
$$


The strength transfer coefficient $\mathrm{C}$ for the given samples has the following values:

- S1 sample: Warp 1.14; Weft 0.97;

- S2 sample: Warp 0.78; Weft 1.03;

- S2 sample: Warp 1.16; Weft 1.56.

Closer these coefficients are from unity the more linear is the transfer rate, above one means the existing woven structure and treatment strengthens the yarn properties. From this we observed S1 and S3 structures to be superior in this regard.

One of the most important properties for these fabrics is the air permeability $[3,4]$ and we tried to reduce this by catering several aspects:

- Yarn torsion of the two systems;

- The use of specially designed connections like ripstop or double ripstop type, with a binding segment of maximum two which interrupt the tendency of the wires of one system to slide towards the wires of the other system (not recommended to use the connections D2/1, R2/1, R1/2 or P2/2).
- Finishing treatment, polyurethane coating.

Two woven types of fabrics were developed accordingly to the following weave diagrams and general characteristics:

- Yarn fiber composition: 100\% PA6.6HT;

- Yarn linear density: 30 den/32 f;

- Yarn count warp: 495 threads/10 cm;

- V1 Yarn count weft: 504 threads/10 cm (figure 3);

- V2 Yarn count weft: 508 threads/10 cm (figure 4).

Four fabric variants were developed as follows:

- a fabric with ripstop connection (V1 and V3) and

- another double-ripstop (V2 and V4).

Each connection variant was made in two finishing variants:

- calendering (V1 and V2) and

- polyurethane coating (V3 and V4) thus resulting in four variants of finished fabrics.

In table 2 are listed the test results and methods used for these finished fabrics.

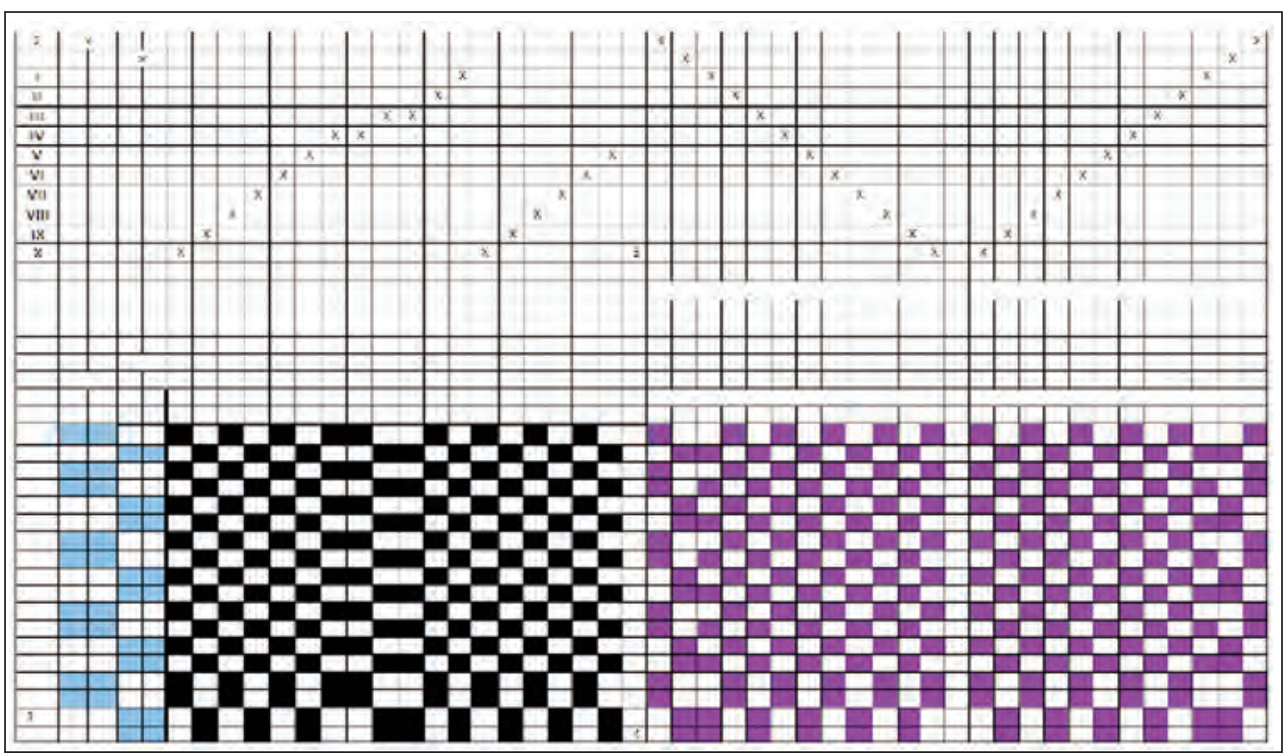

Fig. 3. Programming card for weave structure V1 (Ripstop weave)

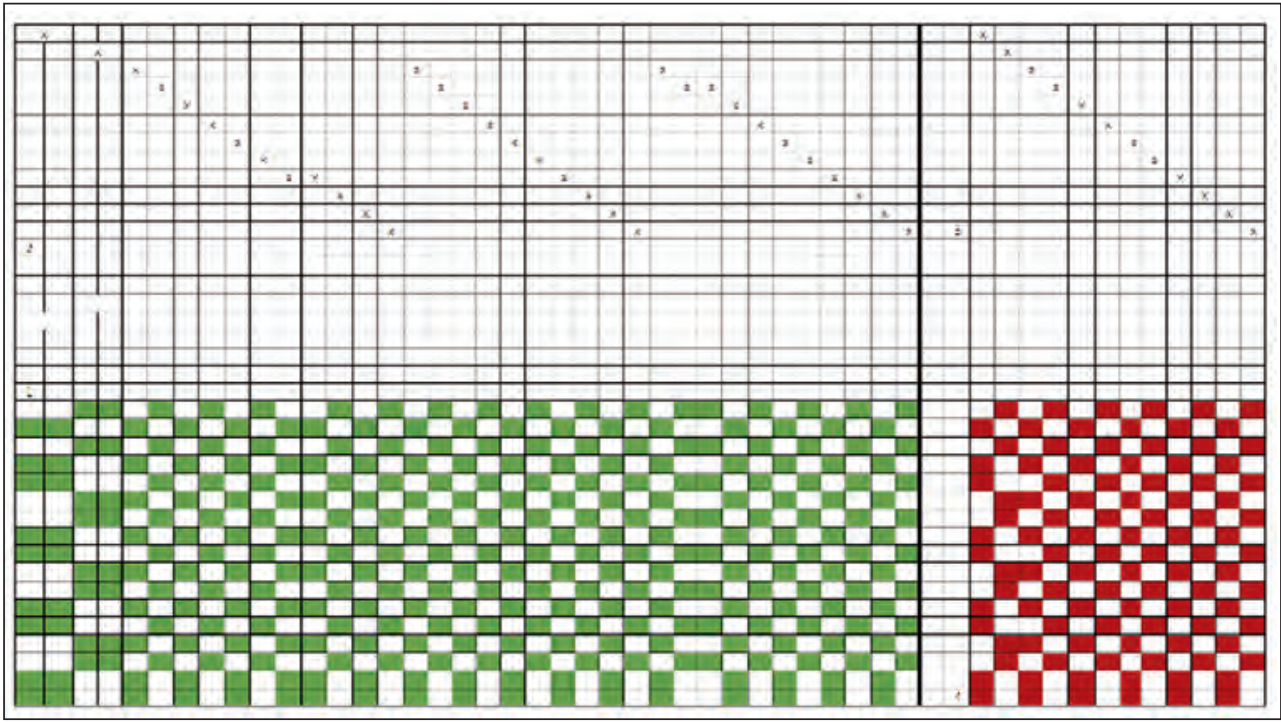

Fig. 4. Programming card for weave structure V2 (Double ripstop weave) 


\begin{tabular}{|c|c|c|c|c|c|c|}
\hline \multicolumn{7}{|c|}{ TEST RESULTS } \\
\hline \multicolumn{2}{|l|}{ Test Name } & Fabric V1 & Fabric V2 & Fabric V3 & Fabric V4 & Testing method \\
\hline \multicolumn{2}{|l|}{ Fabric mass $\left(\mathrm{g} / \mathrm{m}^{2}\right)$} & 40 & 51 & 47 & 59 & SR EN 12127:2003 \\
\hline \multirow{2}{*}{ Yarn count (threads/10 cm) } & Warp & 495 & 495 & 495 & 495 & \multirow{2}{*}{ SR EN 1049-2:2000 } \\
\hline & Weft & 504 & 508 & 504 & 508 & \\
\hline \multirow{2}{*}{ Fabric breaking strength $(\mathrm{N})$} & Warp & 440 & 554 & 422 & 541 & \multirow{4}{*}{$\begin{array}{l}\text { SR EN ISO 13934-1: } \\
2013\end{array}$} \\
\hline & Weft & 445 & 484 & 410 & 480 & \\
\hline \multirow{2}{*}{$\begin{array}{l}\text { Fabric elongation at breaking } \\
\text { force }(\%)\end{array}$} & Warp & 28.6 & 23.6 & 26.7 & 24.9 & \\
\hline & Weft & 32.7 & 26.2 & 38.4 & 29.1 & \\
\hline \multirow{2}{*}{ Fabric tearing strength $(\mathrm{N})$} & Warp & 34.4 & 21.3 & 65.2 & 20.7 & \multirow{2}{*}{$\begin{array}{l}\text { SR EN ISO 13937-2: } \\
2001\end{array}$} \\
\hline & Weft & 32.7 & 22.5 & 65.5 & 20.7 & \\
\hline \multicolumn{2}{|l|}{ Fabric bursting strength $(\mathrm{KPa})$} & 330.3 & 368.4 & 330.2 & 370.8 & \multirow{2}{*}{ EN ISO 13938-2/ 2002} \\
\hline \multicolumn{2}{|l|}{ Fabric bursting strength (mm) } & 35.4 & 36.3 & 42.5 & 43.2 & \\
\hline \multicolumn{2}{|l|}{$\begin{array}{l}\text { Fabric air permeability }\left(1 / \mathrm{m}^{2} / \mathrm{s}\right) \\
\text { at } 200 \mathrm{~Pa}\end{array}$} & 10.53 & 10.34 & 0 & 0 & SR EN ISO 9237:1999 \\
\hline \multicolumn{2}{|l|}{ Raw material } & $\begin{array}{c}100 \% \\
\text { PA66HT }\end{array}$ & $\begin{array}{c}100 \% \\
\text { PA66HT }\end{array}$ & $\begin{array}{c}100 \% \\
\text { PA66HT }\end{array}$ & $\begin{array}{c}100 \% \\
\text { PA66HT }\end{array}$ & SR 13231-95 \\
\hline \multicolumn{2}{|l|}{ Coating } & Calendered & Calendered & PU coating & PU coating & SR ISO 1833-95 \\
\hline \multicolumn{2}{|l|}{ Link type } & Ripstop & $\begin{array}{l}\text { Double- } \\
\text { ripstop }\end{array}$ & Ripstop & $\begin{array}{l}\text { Double- } \\
\text { ripstop }\end{array}$ & - \\
\hline
\end{tabular}

\section{CONCLUSIONS}

The fabric breaking strength is in line with the breaking strength of the yarn, this validates the testing methods and yarn extraction method. A strength transfer coefficient greater than one means the woven structure has higher theoretical tenacity than all the yarns combined. This means that the calendred fabric S3 woven structure amplifies better the yarn tenacity than coated fabrics; however the S1 fabric is not far behind and has way better breaking strength, lower elongation and also lower air permeability, probably because of the double-ripstop structure.

The highest yarn elongation of S2 influences in an interesting way the tearing behaviour and tearing strength results. The S2 fabric gets the highest tearing resistance due to this but is not necessarily the correct one since the fabric torn incompletely. Some threads remained in structure and influenced the results.

Due to the nature of the single sail wing, the amount of fabric used in the manufacture is almost halved therefore the fabric can be a little heavier and also can have a less than perfect air permeability because the shape is maintained by several rigid members. Thus we conclude that the fabric must use yarn of high tenacity Nylon 66; then make use of the rip-stop weave link and polyurethane coating.
The fabric variants obtained were tested and these conclusions were drawn:

- Regarding the air permeability, the most performing variants were the coated ones (V3 and V4).

- Considering the specific mass, the lightest fabric is the $\mathrm{V} 1$ variant.

- Considering the breaking resistances, all variants are in the same performance class but with significantly higher values in the case of double-ripstop variants V2 and V4. However, increased tear strength is observed in the case of the V 3 variant, this is due to the tearing mode which opposes the propagation of the rupture. This type of tearing behaviour is presented by both $\mathrm{V} 1$ and $\mathrm{V} 3$.

- Further testing is required to decide if the fabric can be functionalized with hydrophobic properties in order to expand the operational capabilities of the UAV for rainy weather or with applied heating elements for use on sub-zero temperatures or high altitude flying.

- Analysing the results and given the desirable tearing behaviour of the V3 variant, we choose this working variant for the UAV textile structure prototype manufacturing in the next stages of system design. 


\section{REFERENCES}

[1] Knache, T.W., Parachute Recovery Systems - Design Manual, Para Publishing, Santa Barbara, California, 1992

[2] Poynter, D., The Parachute Manual - A Technical Treatise on Aerodynamic Decelerators, vol. 2, Santa Barbara, California, 1984

[3] U.S. Department of Transportation, Parachute rigger handbook, FAA Flight Standards Service, 2005

[4] Cristian, I., Nauman, S., Boussu, F., Koncar, V., A Study of Strength Transfer from tow to Textile Composite Using Different Reinforcement Architectures, In: Appl. Compos. Mater., 2012, 19, 3-4, 447-458, https://doi.org/10.1007/ s10443-011-9215-x

Authors:

\section{ADRIAN SĂLIȘTEAN, CARMEN MIHAI}

National Research and Development Institute for Textiles and Leather, DCSTA,

16, Lucretiu Patrascanu Street, 030508, Bucharest, Romania

email: office@incdtp.ro

Corresponding author:

ADRIAN SĂLIȘTEAN

e-mail: adrian.salistean@incdtp.ro 


\title{
The holiday effects in stock returns: a challenge for the textile and clothing industry of India
}

DOI: 10.35530/IT.071.04.1710

\author{
BOLAR SHAKILA \\ PINTO PRAKASH \\ IQBAL THONSE HAWALDAR
}

CRISTI SPULBAR

\section{ABSTRACT - REZUMAT}

The holiday effects in stock returns: a challenge for the textile and clothing industry of India

This research paper examines the holiday effects presence on the Bombay Stock Exchange (BSE), which is a major Indian stock exchange. Textile and clothing industry in India is one of the most important producers in the world, but also the second exporter of textile and apparels globally. The empirical analysis investigates the impact of holiday effect on the development of textile and clothing industry in India. The holiday effect is one of the most important calendar anomalies identified in the financial markets. The methodological approach includes the non-parametric Mann-Whitney $U$-test used to test the equality of means for different sub-sets. The findings revealed that the mean returns for pre-holiday and post holidays were greater compared to that of remaining days, but the empirical results showed that they were not statistically significant for selected stocks of BSE based on daily stock returns data for Ruby Mills and Mafatlal Industries.

Keywords: textile, clothing, pre-holiday effect, calendar anomaly, abnormal returns, Efficient Market Hypothesis (EMH), non-parametric Mann-Whitney U-test

\section{Influența sărbătorilor legale asupra rentabilității piețelor bursiere: o provocare pentru industria textilă} și de îmbrăcăminte din India

Acest articol de cercetare examinează prezența efectelor generate de sărbătorile legale în cazul Bombay Stock Exchange (BSE), care este principala piață bursieră indiană. Industria textilă și a îmbrăcămintei din India reprezintă unul dintre cei mai importanți producători din lume, dar și al doilea exportator de materiale textile și îmbrăcăminte la nivel global. Analiza empirică investighează impactul efectului de sărbătoare asupra dezvoltării industriei textile și de îmbrăcăminte din India. Efectul sărbătorilor reprezintă una dintre cele mai importante anomalii calendaristice identificate pe piețele financiare. Metodologia de cercetare include testul nonparametric Mann-Whitney $U$ utilizat pentru a testa egalitatea mediilor pentru diferite sub-seturi. Concluziile au relevat că randamentul mediu pentru perioada ante-sărbătoare și post-sărbătoare a fost mai mare în comparație cu cel al zilelor rămase, dar rezultatele empirice nu au fost semnificative statistic pentru indicii sectoriali selectați ai BSE, pe baza randamentelor zilnice pentru Ruby Mills și Mafatlal Industries.

Cuvinte cheie: materiale textile, îmbrăcăminte, efect ante-sărbătoare legală, anomalie calendaristică, rentabilitate anormală, ipoteza pieței eficiente (EMH), testul nonparametric Mann-Whitney $U$

\section{INTRODUCTION}

According to the Ministry of Textiles in India, the textile industry contributes to $7 \%$ of Indian industry output in value terms, $2 \%$ of the country's GDP and to $15 \%$ of India's export earnings with over 45 million people employed. The textiles industry in India is currently estimated at around US $\$ 150$ billion, but is expected to reach US $\$ 250$ billion by 2019. A traditional textile market is an area of high interest and is destined to apparel and accessories, households, furnishings and floor coverings [1]. The textile industry in India has two main pillars: yarn and fibre, and processed fabrics and apparel considering that manmade garments represents the largest contributor to total textile and apparel exports from India [2]. The textile and clothing industry in India includes commodities such as: man-made fibres and filaments, cotton, vegetable textile fibres, rug weaving, textile floor coverings, carpet weaving and others. India is an emerging country, but also a member of the BRICS group which includes Brazil, Russia, India, China and South Africa. Moreover, [3] suggested that textile industry also plays a critical role in terms of output, export and employment in the manufacturing sector of China which is one of the BRICS countries, just like India. The stylized facts that characterize an emerging economy include the existence of pro-cyclical policies, fragile economic and financial structure, a high rate of economic growth based mainly on consumption, vulnerability to foreign currency volatility movements, lower per-capita incomes, lack of fiscal transparency and socio-political instability. Portfolio Systematic patterns exhibited by stock returns at specific times of the day, week or month are known as calendar anomalies or calendar effects. Calendar 
anomaly is a type of market anomalies which contradicts the traditional theory of Efficient Market Hypothesis (EMH).

The classic paradigm of Efficient Market Hypothesis $(E M H)$ was widely accepted since the early 1970 s and is based on three essential pillars such as investor rationality, uncorrelated errors, and the assumption that there are no limits to arbitrage. According to [4] the ideal financial market would be guided by the principle that prices provide accurate signals for resource allocation. Stock market efficiency implies that security prices at any moment "fully reflect" all available information. [5], also known as the father of efficient market hypothesis suggested that: "anomalies are chance results, apparent overreaction to information is about as common as underreaction, and post-event continuation of pre-event abnormal returns is about as frequent as post-event reversal". Efficient market hypothesis promotes the idea that a stock market provides correct pricing, and current prices of securities are close to their fundamental values [6]. The fundamental pillar on which the EMH paradigm relies on suggests that stock market security prices always incorporate and reflect all relevant information [7]. Moreover, in an efficient market, arbitrage opportunities are rather insignificant. In other words, it's not possible to outperform the market over the long-term.

On the other hand, behavioural finance paradigm suggests that investment decision is influenced in a large proportion by psychological and emotional factors. [8] suggested that behavioural finance has two building blocks: limits to arbitrage, which argues that it can be difficult for rational traders to undo the dislocations caused by less rational traders and psychology, which methodizes the categories of deviations from full rationality we might expect to acknowledge. In literature, there are three main forms of efficiency, namely weak, semi-strong and strong forms of market efficiency. Calendar effects, specifically, violate the weak form of efficiency, emphasizing the importance of past patterns and seasonality in estimating future prices [9]. However, recent empirical studies on calendar anomalies or seasonal anomalies revealed that some of the calendar anomalies like day of the week effect, month of the year effect and turn of the month effect seem to have weakened or disappeared over the sample time period (see empirical studies [10-15]). Nevertheless, this empirical study attempts to investigate the existence of holiday effect in Indian stock market.

\section{LITERATURE REVIEW}

In the literature, two main pillars of the holiday effect were identified: a) the pre-holiday effect (the price returns of the days preceding the holidays are considerably different from those in other trading days), and b) the post-holiday effect (the price returns of the days that follow the holidays are considerably different from those in other trading days). Technically, the post-holiday represents at least one day after the holiday. However, the post-holiday effect is rarely identified in recent empirical evidence. The holiday effect is one of the most significant calendar anomalies identified on the financial markets. It is characterized by the fact that abnormally high stock returns are reported on at least one day preceding the holiday. The reason could be the excitement or euphoria of financial investors to buy shares before the holidays [16]. For instance, impediments to trading small, illiquid stocks prevent arbitrage activities from eliminating anomalies [17]. Till date, the studies conducted on holiday effect provided mixed results.

Other researchers [18-23] confirm the presence of holiday effect on international stock markets.

Whereas, several researchers [20, 24-26] concluded that holiday effect had disappeared during the sample period. Moreover, Rufael et al. [27] investigated holiday-effect in Indian stock market specifically Pre, Post-Holiday and weekday's effects based on BSE Sensex and NSE Nifty index returns and concluded that Pre-Holiday shows the good returns among other trading days. Further, it is worth noting that a very limited number of empirical research studies on holiday effect have been conducted on Indian stock markets. Hence, this study would make a sensible contribution to literature on Indian stock market. Moreover, this research paper is also very useful for a better understanding of other international emerging markets with similar behaviour.

The early contribution to holiday effect was made by Merrill [28] who researched Dow Jones Industrial Average from 1897 to 1965 found significantly higher returns on days before and after the public holidays. Other researchers [29-30] found significant stock returns before the US public holidays. Coutts et al. reported the presence of Pre-Holiday effects in the All Gold Index on the Johannesburg Stock Exchange did not exist for the period between 1987 and 1997 [21]. In a study conducted by Chong et al. [31] for the US, UK and Hong Kong markets, it was found that holiday effect seemed to be declined, but only significant in the US market for during the period 1991 to 1997. Moreover Pinto et al. [32] argued that risk anomaly represents a significant kind of anomaly considering it is continual and all-inclusive. Cao et al. [33] analyzed the behaviour of New Zealand stock returns by taking a sample from three major indices over four decades from January 1967 to January 2006. The results of the study indicated that pre-holiday existed in the New Zealand market and interestingly it was found pre-holiday effects were limited to firms in the Small Cap Index, compared to Medium Cap and Large Cap firms. Njeri [34] has identified the presence of holiday effect on stock returns of the Nairobi Securities Exchange based on the sample databases. In addition, Tangjitprom [22] examined the holiday effect in Thailand stock returns and volatility during the period from 1994 to 2009 and discovered the existence of significant high returns and higher volatility during the pre-holiday trading day. The results of the study conducted in the Romanian stock market indicated a post-holiday effect for all the indexes under 
study and a pre-holiday effect only for some of them [35]. Hawaldar et al. [36-37] found that the effect events on stock returns in the Indian stock market are not significant, and market reaction is very slow. Dodd et al. [38] examined the holiday effect in fourteen emerging Central and Eastern European (CEE) markets for a period from January 1991 to December 2010. The authors found in many countries significant pre-holiday and post-holiday returns.

Karim et al. [26] studied the Malaysian stock market for the period between 2001 and 2009 and found that there was no significant difference in the mean returns between pre-holiday period and rest of the period. Alagidede [39] found high and significant for the period between 1997 and 2006 pre-holiday effects in African stock returns. Further evidence of holiday effect was provided by Teng et al. [23] who examined the Taiwan Stock Exchange for the period from 1971 to 2011 . The findings of the study made by Kendirli et al. [40] on the stock returns of Shanghai Stock Exchange (SSE) for a period between 2001 and 2012 indicated that although the calendar anomalies were detected, they were not persistent. Very recently, a study conducted by Kamau [41] in the Nairobi Securities Exchange between 2010 and 2015 found the presence of holiday effect. In the Indian context, Nageswari et al. [42] analysed the S\&P CNX Index for ten years and found the highest but insignificant pre-holiday returns during the study period. Shankar et al. [13] studied the holiday effect in Indian BSE Sensex Indices over some time of 2009 to 2015 and found a significant change in the post-holiday Sensex returns for the study period. Lu et al. [43] investigated the impact of holiday anomaly in the Indian stock market and have empirically confirmed the existence of higher returns on the trading day following a public holiday, compared to regular trading days. As additional research perspective, Kim et al. [44] have empirically identified abnormally high returns on the trading day before holidays in certain main stock markets in the U.S. (NYSE, AMEX, and NASDAQ) but also concluded that the holiday effects in the U.K. and Japanese stock markets are independent of the holiday effect in the U.S. stock market. Moreover, Sasikirono et al. [45] have empirically demonstrated that holiday effect also occurs in Indonesia, where the post-holiday average return four times higher than the average return of other trading day. Moreover, Robins et al. [46] suggested that the holiday effect is statistically significant in the CRSP value-weight stock market portfolio and the low-size stock portfolio in every sub-period from 1926 to 2016 considering that the average stock return on the day before holiday market closings is up to 15 times the average return on all the other days of the year.

The literature review provided a comprehensive framework on holiday effect. A significant part of the previous research studies have demonstrated the presence of holiday effects on selected emerging or developed stock markets. Consequently, the results obtained in this study are consistent with similar empirical research studies.

\section{DATA AND METHODOLOGY}

The textile industry in India is an essential segment and is affected by stock market behaviour and this has multidimensional implications for sustainable economic development. To examine the presence of holiday effect in Indian stock market, the study uses daily closing prices of Ruby Mills and Mafatlal Industries which are major stocks in the textile industry traded in Bombay Stock Exchange for the sample period from January 2010 to December 2019. Over the past decade, the BSE behaviour has been empirically analyzed to identify the present holiday effect. Holidays are those days on which no trading activities are carried on in the Indian stock market.

The holidays that are taken into consideration for empirical analysis are the following: Mahashivratri, Id-EMilad, Good Friday, Dr. Ambedkar Jayanti, Mahavir Jayanti, Holi, Independence Day, Ganesh Chaturthi, Ramzan Id/Gandhi Jayanti, Dasera, Mohurum, Diwali, Bakri-Id, and Christmas. The holidays that occurred on Saturdays on Sundays are not considered for the present empirical study. To test the holiday effect, the daily percentage logarithmic returns for ten years time period are calculated by applying the following equation:

$$
R_{t}=\ln \frac{P_{t}}{P_{t-1}} \times 100
$$

where $R_{t}$ is daily return on the index, In - natural log of underlying market series, $P_{t}$ - closing value of a given index on a specific trading day $(t)$ and $P_{t-1}-$ closing value of a given index on a preceding day $(t-1)$.

To test the pre-holiday effect in select stocks of BSE, the non-parametric Mann-Whitney U-test is used. It is applied when there are two independent samples drawn from the same population. Hence, to test the equality of mean returns between two subsets viz pre-holidays and remaining days and post-holidays and remaining days, Mann Whitney U-test is used:

$$
U=n_{1} n_{2}+\frac{n_{2}\left(n_{2}+1\right)}{2}-\sum_{i-n t+1}^{n_{2}} R_{i}
$$

where $U$ is Mann Whitney U-test, $n_{1}$ - sample size one, $n_{2}$ - sample size two, $R_{i}$ - Rank of the sample size.

In order to investigate the holiday effect in select sectoral indices of BSE, the total number of 2,364 trading days is divided into the following main groups:

1. Pre-holidays, i.e. trading days before the holidays. In this category, three subsets have been identified:

(i) one day before a holiday ( $\mathrm{T}-1)$

(ii) two days before the holiday (T-2)

(iii) three days before the holiday ( $\mathrm{T}-3$ )

2. Post-holidays, i.e. trading days after holidays. Here also three subsets are formed, such as:

(i) one day after the holiday $(\mathrm{T}+1)$

(ii) two days after the holiday $(\mathrm{T}+2)$ 
(iii) three days after the holiday $(T+3)$

3. Remaining Days. These include all trading days except one day before holidays ( $T-1)$.

Further, the results are tested by using the following hypotheses.

\section{Hypothesis 1}

$\mathrm{H}_{0}$ - There is no significant difference between mean returns of pre-holidays and that of remaining days in select stocks of BSE.

$H_{1}$ - There is a significant difference between mean returns of pre-holidays and that of remaining days in select stocks of BSE.

\section{Hypothesis 2}

$\mathrm{H}_{0}$ - There is no significant difference between mean returns of post-holidays and that of remaining days in select stocks of BSE

$H_{1}$ - There is a significant difference between mean returns of post-holidays and that of remaining days in select stocks of BSE.

\section{DATA ANALYSIS AND INTERPRETATION}

\section{Ruby Mills}

Tables 1 and 2 exhibit descriptive statistics for the pre-holidays, post-holiday and remaining days in Ruby Mills. As shown in the tables 1 and 2 mean returns of pre-holidays (1.5835) are 29.43 times higher compared to means of remaining days (0.0538) and also the results of Mann-Whitney $U$ test $(p=0.001<0.05)$ confirm that there is significant difference between the mean returns of pre holidays and remaining days in Ruby Mills. The findings are in agreement with the previous literature on holiday effect across the global stock markets.

Further, the mean returns of post holidays $(-2.0142)$ found to be negative compared to the means of remaining days (0.0538) and the results of MannWhitney $U$ test $(p=0.218>0.05)$ also reveal that they are not statistically significant.

To make a comprehensive analysis of holiday effect, the days surrounding holidays are identified and descriptive statistics are calculated for each subset. As observed in table 3, in pre-holidays, the two days before holiday ( $T-2)$ reported greater returns (1.608), three days before the holiday $(T-3)$ showed lowest mean returns $(0.248)$ and the average of pre-holiday returns is 1.15 . Where as in post-holiday returns the
DESCRIPTIVE STATISTICS OF PRE-HOLIDAYS, POST HOLIDAYS AND REMAINING DAYS FOR RUBY MILLS BETWEEN 2010 AND 2019

\begin{tabular}{|c|c|c|c|}
\hline $\begin{array}{c}\text { Period } \\
\text { 2010-2019 }\end{array}$ & $\begin{array}{c}\text { Pre-holidays } \\
\text { (T-1) }\end{array}$ & $\begin{array}{c}\text { Remaining } \\
\text { days }\end{array}$ & $\begin{array}{c}\text { Post } \\
\text { holidays } \\
\text { (T+1) }\end{array}$ \\
\hline $\begin{array}{c}\text { No. of } \\
\text { observations }\end{array}$ & 114 & 2136 & 114 \\
\hline Mean & 1.5835 & 0.0538 & -2.014 \\
\hline Std deviation & 0.205 & 9.372 & 20.781 \\
\hline Minimum & 2.8626 & -17.67 & -76.452 \\
\hline Maximum & 4.0799 & 55.58 & 55.43 \\
\hline Skewness & -0.487 & 3.520 & -0.576 \\
\hline Kurtosis & 2.460 & 14.02 & 2.739 \\
\hline
\end{tabular}

Table 2

\begin{tabular}{|c|c|c|}
\hline \multicolumn{2}{|c|}{ RESULTS OF INDEPENDENT SAMPLE TEST } \\
\hline Sub-sets & $\begin{array}{c}\text { Pre-holidays } \\
(\mathrm{T}-1) \text { \& remaining } \\
\text { days }\end{array}$ & $\begin{array}{c}\text { Post holidays } \\
(\mathrm{T}+1) \text { \& remaining } \\
\text { days }\end{array}$ \\
\hline $\begin{array}{c}\text { Results of } \\
\text { Mann-Whitney } \\
\text { U-test }\end{array}$ & $\begin{array}{c}(\mathrm{Z} \text { value })=-12.29 \\
* \mathrm{p}=0.001(\mathrm{~S})\end{array}$ & $\begin{array}{c}(\mathrm{Z} \text { value })=-1.233 \\
* \mathrm{p}=0.218(\mathrm{NS})\end{array}$ \\
\hline
\end{tabular}

* $0.01=p<0.05$ Significant and

** $0.01<p>0.05$ Not Significant

3 days after the holiday $(T+3)$ reported positive returns $(0.077)$, one day after holidays $(T+1)$ recorded lower returns $(-2.104)$ and the average of postholiday returns is -1.19 , which is considerably lower than average returns of pre-holidays.

\section{Mafatlal Industries}

Table 4 exhibits descriptive statistics for the pre-holidays, post-holiday and remaining days for Mafatlal Industries. As shown in the table 4 mean returns of pre-holidays (1.212) are 1.19 times higher compared to means of remaining days (1.020) but they are not statistically significant as shown in table 5 ( $p=0.086$ $>0.05)$. Further, in contrast to the previous studies, the mean returns of post holidays (2.47) found to be 2.42 times greater than means of remaining days (1.020) and the results of Mann-Whitney $U$ test as

\begin{tabular}{|c|c|c|c|c|c|c|}
\hline \multicolumn{7}{|c|}{$\begin{array}{c}\text { DESCRIPTIVE STATISTICS OF RETURNS FOR DAYS SURROUNDING HOLIDAYS IN RUBY MILLS } \\
\text { BETWEEN } 2010 \text { AND } 2019\end{array}$} \\
\hline Period 2010-2019 & $(T-3)$ & $(T-2)$ & $(T-1)$ & $(T+1)$ & $(T+2)$ & $(T+3)$ \\
\hline No. of observations & 28 & 35 & 114 & 114 & 35 & 28 \\
\hline Mean & 0.248 & 1.608 & 1.584 & -2.014 & -1.548 & 0.077 \\
\hline Std deviation & 29.933 & 25.348 & 0.205 & 20.781 & 24.550 & 33.099 \\
\hline Minimum & -74.5069 & -75.6786 & 2.862 & -76.452 & -73.554 & -73.594 \\
\hline Maximum & 48.5750 & 57.1257 & 4.079 & 55.43 & 51.952 & 45.39 \\
\hline Skewness & 0.683 & -0.300 & -0.487 & -0.576 & -0.505 & 1.236 \\
\hline Kurtosis & 3.405 & 1.683 & 2.460 & 2.739 & 1.640 & 4.891 \\
\hline
\end{tabular}


DESCRIPTIVE STATISTICS OF RETURNS FOR

PRE-HOLIDAYS, POST HOLIDAYS AND REMAINING DAYS FOR MAFATLAL INDUSTRIES DURING 2010-2019

\begin{tabular}{|c|c|c|c|}
\hline $\begin{array}{c}\text { Period } \\
\mathbf{2 0 1 0 - 2 0 1 9}\end{array}$ & $\begin{array}{c}\text { Pre-holidays } \\
\text { (T-1) }\end{array}$ & $\begin{array}{c}\text { Remaining } \\
\text { days }\end{array}$ & $\begin{array}{c}\text { Post } \\
\text { holidays } \\
\text { (T+1) }\end{array}$ \\
\hline $\begin{array}{c}\text { No. of } \\
\text { observations }\end{array}$ & 114 & 2136 & 114 \\
\hline Mean & 1.2123 & 1.0203 & 2.4703 \\
\hline Std deviation & 17.8285 & 3.3466 & 17.679 \\
\hline Minimum & -23.912 & -21.849 & -27.726 \\
\hline Maximum & 71.0721 & 18.2234 & 86.125 \\
\hline Skewness & 1.151 & 0.051 & 2.278 \\
\hline Kurtosis & 4.491 & 4.288 & 9.535 \\
\hline
\end{tabular}

Table 5

RESULTS OF INDEPENDENT SAMPLE TEST

\begin{tabular}{|c|c|c|}
\hline Sub-sets & $\begin{array}{c}\text { Pre-holidays } \\
(\mathrm{T}-1) \text { \& remaining } \\
\text { days }\end{array}$ & $\begin{array}{c}\text { Post holidays } \\
(\mathrm{T}+1) \text { \& remaining } \\
\text { days }\end{array}$ \\
\hline $\begin{array}{c}\text { Results of } \\
\text { Mann-Whitney } \\
\text { U-test }\end{array}$ & $\begin{array}{c}(\mathrm{Z} \text { value })=-1.715 \\
{ }^{*} \mathrm{p}=0.086(\mathrm{NS})\end{array}$ & $\begin{array}{c}(\mathrm{Z} \text { value })=-1.914 \\
\mathrm{p} p=0.015(\mathrm{NS})\end{array}$ \\
\hline
\end{tabular}

Note: ${ }^{*} 0.01<p>0.05$ Not Significant mean returns ( -3.20 and -5.50 respectively) and the average of pre-holiday returns is -2.50 . Where as in post-holiday returns the one day after the holiday $(T+1)$ reported higher returns (2.47), two days after holiday $(T+2)$ recorded negative returns $(-3.56)$ and the average of post-holiday returns is -0.35 , which is better than average returns of pre-holidays.

\section{CONCLUSIONS}

Holiday effect is a kind of calendar anomalies which is less explored in Indian stock market. Using daily stock returns data for Ruby Mills and Mafatlal Industries the current study tested pre-holiday effect and post holiday effect in Indian stock market for the period between 2010 and 2019. The results of the study indicated that in case of Ruby Mills that mean returns of pre-holiday are greater compared to that of remaining days and they are statistically significant. Whereas Mafatlal Industries reported greater but insignificant pre holidays returns during the study period. Further, in respect of both select stocks the mean returns of post holidays found to be greater than that of remaining days and however the test results confirmed that they are not statistically significant. The results of the study nullified the presence of post-holiday effect in both select stocks.

Further, mean returns for the days surrounding holidays are calculated and it was found that Ruby Mills showed higher average of pre-holiday returns as compared to average of post-holiday returns On the

DESCRIPTIVE STATISTICS OF RETURNS FOR DAYS SURROUNDING HOLIDAYS MAFATLAL INDUSTRIES DURING 2010-2019

\begin{tabular}{|c|c|c|c|c|c|c|}
\hline Period 2010-2019 & $\mathbf{( T - 3 )}$ & $\mathbf{( T - 2 )}$ & $\mathbf{( T - 1 )}$ & $\mathbf{( T + 1 )}$ & $\mathbf{( T + 2 )}$ & $\mathbf{( T + 3 )}$ \\
\hline No. of observations & 28 & 35 & 114 & 114 & 35 & 28 \\
\hline Mean & -5.503 & -3.201 & 1.212 & 2.4703 & -3.562 & 0.054 \\
\hline Std deviation & 40.63 & 25.91 & 17.8285 & 17.6797 & 25.289 & 1.502 \\
\hline Minimum & -21.23 & -66.32 & -23.9122 & -27.726 & -4.90 & -4.665 \\
\hline Maximum & 70.24 & 65.06 & 71.0721 & 86.1254 & 45.90 & 5.252 \\
\hline Skewness & -1.201 & -0.091 & 1.151 & 2.278 & -0.743 & -1.696 \\
\hline Kurtosis & 3.839 & 1.727 & 4.491 & 9.535 & 5.781 & 3.60 \\
\hline
\end{tabular}

shown in table $5(p=0.067>0.05)$ confirm that there is no significant difference between the means of post holidays and remaining days in Mafathlal Industries.

As observed in table 6 in pre-holidays, the one day before holiday $(T-1)$ reported greater returns (1.21), whereas two days before holiday ( $\mathrm{T}-2)$ and three days before the holiday $(T-3)$ reported negative other hand Mafatlal Industries showed differing effects as both the averages reported negative returns. Finally, it could be inferred that the present study could not find significant post-holiday effect whereas the presence pre-holiday effect was evident only in case of Ruby Mills during the study period. Further, the study can be extended to other stocks of Textile Industries traded in Bombay Stock Exchange.

\section{REFERENCES}

[1] Ministry of Textiles, Government of India, Annual Report 2017-2018, Available at: http://texmin.nic.in/documents/ annual-report [Accesed June 2019]

[2] India Brand Equity Foundation, An initiative of the Ministry of Commerce \& Industry, Government of India, Available at: https://www.ibef.org/industry/textiles.aspx [Accesed June 2019] 
[3] Yuan, H., Hong, Y., Zhang, J., Hongzhong Zhao, Zhang, Y., Effects of agglomeration externalities on total factor productivity: evidence from China's Textile Industry, In: Industria Textila, 2017, 68, 6, 474-480, http://doi.org/ 10.35530/IT.068.06.1408

[4] Fama, E., Efficient Capital Markets: a review of theory and empirical work, In: The Journal of Finance, 1970, 25, 2, 383-417

[5] Fama, E., Market efficiency, long-term returns, and behavioural finance, In:Journal of Financial Economics, 1998, 49, 283-306

[6] Fama, E., Random Walks in Stock Market Prices, In: Financial Analysts Journal, 1965

[7] Spulbar, C., Birau, R., Emerging Research on Monetary Policy, Banking, and Financial Markets, In: IGI Global, USA, 2019, 322, http://doi.org/10.4018/978-1-5225-9269-3

[8] Barberis, N., Thaler, R., A survey of behavioural finance, Handbook of the Economics of Finance, Elsevier Science B.V., 2003

[9] Kumar, H., Rachna, J., Efficient Market Hypothesis and Calendar Effects: Empirical Evidences from the Indian Stock Markets, In: Business Analyst, 2017, 37, 2, 145-160

[10] Wong, W. K., Agarwal, A., Wong, N.T., The Disappearing Calendar Anomalies in the Singapore Stock Market, In: The Lahore Journal of Economics, 2006,123-139

[11] Ahsan, A., Sarkar, A., Does January Effect Exist in Bangladesh?, In: International Journal of Business and Management, 2013, 8, 7, 82-89

[12] Gouider, J.J., Kaddour, A., Hmaid, A., Stock Market Anomalies: Case of Calendar Effects on the Tunisian Stock Market, In: Global Journal of Management and Business Research (B), Economics and Commerce, 2015, 15, 2

[13] Shankar, R.G., Kallarackal, T.K., A Study of Holiday Effect on Sensex Returns in the Indian Market, In: International Journal of Research in Finance and Marketing (IJRFM), 2016, 6, 11, 63-68

[14] Shakila, B., Pinto, P., Hawaldar, I.T., Semi-monthly effect in stock returns: new evidence from Bombay, In: Investment Management and Financial Innovations, 2017, 14, 3, 160-172

[15] Hawaldar, I. T., Shakila, Pinto, P., Empirical Testing of Month of the Year Effect on selected commercial banks and Services Sector Companies Listed on Bahrain Bourse, In: International Journal of Economics and Financial Issues, 2017, 7, 2, 426-436

[16] Marrett, G., Worthington, A., An Empirical note on the holiday effect in the Australlian stock Exchange, In: Applied Economics Letters, 2009, 1769-1772

[17] Fang, L., Lin, C., Shao, Y., School Holidays and Stock Market Seasonality, Financial Management (FM), 2017, 47, $1,131-157$

[18] Arsad, Z., Coutts, J. A., Security price anomalies in the London International Stock Exchange: A 60-year perspective, In: Applied Financial Economics, 1997, 7, 5

[19] Brockman, P., Michayluk, D., The holiday anomaly: An investigation of firm size, In: Quarterly Journal of Business and Economics, 1997, 36, 3, 21-39

[20] Vergin, R. C., McGinnis, J., Revisiting the holiday effect: Is it on holiday?, In: Applied Financial Economics, 1999, $9,3,477-482$

[21] Coutts, J. A., Sheikh, M. A., The anomalies that aren't there: the weekend, January and pre-holiday effects on the all gold index on the Johannesburg Stock Exchange 1987-1997, In: Applied Financial Economics, 2012, 12, 12, 863-871

[22] Tangjitprom, N., The Calendar Anomalies of Stock Return in Thailand, In: Journal of Modern Accounting and Auditing, 2011, 7, 6, 565-577

[23] Teng, C. C., Liu, V. W., The pre-holiday effect and positive emotion in the Taiwan Stock Market, 1971-2011, In: Investment Analysts Journal, 2013, 42, 77, 35-43

[24] Keef, S. P., Roush, M. L., Day-of-the-week effects in the pre-holiday returns of the Standard and Poor's 500 stock index, In: Applied Financial Economics, 2005, 15, 107-119

[25] Marquering, W.J., Nisser, Toni, Valla., Disappearing anomalies: a dynamic analysis of the persistence of anomalies, In: Applied Financial Economics, 2006, 16,4, 291-302

[26] Karim, B. A., Karim, Z. A., Nee, T. A., Holiday effects in Malysisa: An Empirical Note, In: International Journal of Research in Economics and Business, 2012, 1, 1, 23-26

[27] Rufael, A.G., Prabakaran, V., Stock Market Anomaly: Evidence from Holiday Effect of Indian Stock Market, In: International Journal of Recent Research and Applied Studies, 2017, 4, 2, 1, 1-5

[28] Merrill, A. A., Behaviour of Prices on Wall Street, In: Journal of Finance, 1966

[29] Pettengill, G.N., Holiday Closings and Security Returns, In: The Journal of Financial Research, 1989, 12, 1, 57-67

[30] Ariel, R. A., High Stock Returns Before Holidays: Existence and Evidence on Possible Causes, In: The Journal of Finance, 1990, 45, 5, 1611-1626

[31] Chong, R., Hudson, R., Keasey, K., Littler, K., Pre-holiday Effects: International Evidence on the Decline and Reversal of a Stock Market Anomaly, In: Journal of International Money and Finance, 2005, 24, 7, 1226-1236

[32] Pinto, P., Hawaldar, I.T, Guruprasad, K., Rohit, B., Spulbar, C., Birau, R. \& Stanciu, C.V., The Impact of Risk Anomalies on the Pharmaceutical Sector of the Indian Stock Market - A Comparative Analysis between Pharmaceutical, FMCG and IT companies, In: Revista de Chimie Journal, 2020, 71, 2, 58-63

[33] Cao, X., Premachandra, I. M., Bharba, G. S., Tang, Y. P., Firm size and the pre-holiday effect in New Zealand, In: International Research Journal of Finance and Economics, 2009, 32, 171-187 
[34] Njeri, K. S., The Holiday effect on Stock Returns at the Nairobi Securities Exchange, School of Business, University of Nairobi, Department of Accounting and Finance, 2016

[35] Dumitriu, R., Stefanescu, R., Nistor, C., Holiday Effects on the Romanian Stock Market, 2011, Available at: http://ssrn.com/abstract=2009186 [Accesed June 2019]

[36] Hawaldar, I.T., Thathaiah, M., Indian stock market reaction to the quarterly earnings information, In: Indian Journal of Finance, 2009, 3, 7, 43-50

[37] Hawaldar, I.T., Thathaiah, M., A study of efficiency of the Indian stock market, In: Indian Journal of Finance, 2010, $5,4,32-52$

[38] Dodd, O., Gakhovich, A., The holiday effect in Central and Eastern European financial markets, In: Investment Management and Financial Innovations, 2011, 8, 29-35

[39] Alagidede, P., The month of the Year and Pre-holiday Effects in African Stock Markets, In: SAJEMS, 2013, 64-74

[40] Kendirli, S., Konak, F., Calendar Anomalies in the Shanghai Stock Exchanges, In:Manas Journal of Social Studies, 2014, 3, 3, 77-85

[41] Kamau, J. W., An Assessment of the holiday anomaly in the Nairobi Securities Exchange (Thesis), Strathmore University, 2017, Available at: http://su-plus.strathmore.edu /handle/11071/5592 [Accesed June 2019]

[42] Nageswari, P., Selvam, M., Holiday effects and index returns: Evidences from the Indian stock market, In: International Journal of Business Economics and Management Research, 2012, 3, 4, 49-57

[43] Lu, X., Patel, N., Festivity Anomaly in Indian Stock Market, In: Economics Bulletin, AccessEcon, 2016, 36, 2 , 851-856

[44] Kim, C.W., Park, J., Holiday effects and stock returns: Further evidence, In: Journal of Financial and Quantitative Analysis, 1994, 29, 1, 145-157

[45] Sasikirono, N., Meidiaswati, H., Holiday Effect in the Indonesian Stock Market, In: Advances in Intelligent Systems Research, 2017, 131, 109-112, International Conference of Organizational Innovation (ICOI 2017), Atlantis Press

[46] Robins, R.P., Smith, G.P., On Structural Changes in the Holiday Effect, In: The Journal of Wealth Management Spring, 2019, 21, 4, 98-105, https://doi.org/10.3905/ jwm.2019.21.4.098

\section{Author:}

BOLAR SHAKILA ${ }^{1}$, PINTO PRAKASH ${ }^{1}$, IQBAL THONSE HAWALDAR $^{2}$, CRISTI SPULBAR ${ }^{3}$, RAMONA BIRAU ${ }^{4}$

${ }^{1}$ St. Joseph Engineering College, Vamanjoor, India

email: bolarshakila@gmail.com, prakashpinto74@gmail.com

${ }^{2}$ College of Business Administration, Kingdom University, Bahrain

e-mail: thiqbal34@gmail.com

${ }^{3}$ University of Craiova, Faculty of Economics and Business Administration, 200585, Craiova, Romania

${ }^{4}$ Faculty of Education Science, Law and Public Administration,

Constantin Brancusi University of Targu Jiu, Romania

e-mail: ramona.f.birau@gmail.com

Corresponding author:

CRISTI SPULBAR

e-mail: cristispulbar7@gmail.com 


\section{Multivariate regression analysis of the 3D composites with electroconductive properties for sensors}

DOI: 10.35530/IT.071.04.1767

\section{ABSTRACT - REZUMAT}

\section{Multivariate regression analysis of the 3D composites with electroconductive properties for sensors}

This work presents several aspects of the multivariate regression importance in the analysis of the parameters (dependent and independent variables), which characterize the 3D composite materials with electroconductive properties. The experimental part was developed by using fabrics from $100 \%$ cotton, $100 \%$ polyamide, and $100 \%$ polypropylene fabrics to obtain the electroconductive and electromagnetic properties based on classical technologies and $3 D$ digital printing advanced technology. The fabric was printed with paste containing zinc, copper, nickel, iron oxide II, III, silver, and Graphite microparticles content. Initially, the fabric has coated using the standard technologies implemented by padding (Flame Retardants), scraping, and $3 D$ printing advanced technology for submission of the ESD filaments. For flame retardancy properties, the fabric has been impregnated in a solution of $50 \%$ Aflamit and dried at a temperature of $120^{\circ} \mathrm{C}$ for 3 minutes.

Keywords: composites, textile, electroconductive, resistance, microparticles, sensors

\section{Analiza de regresie multivariată a compozitelor 3D cu proprietăţi electroconductive pentru senzori}

Această lucrare prezintă câteva aspecte privind importanţa analizei parametrilor (variabile dependente şi independente), care caracterizează materialele compozite 3D cu proprietăţi electroconductive. Pentru realizarea experimentelor au fost utilizate ţesături din 100\% bumbac, 100\% poliamidă şi 100\% polipropilenă pentru obţinerea proprietăţilor electroconductive şi electromagnetice pe baza procedeelor clasice şi avansate de imprimare digitală 3D. Tesăturile au fost imprimate utilizând paste cu conţinut de microparticule de zinc, cupru, nichel, oxid de fier II, oxid de fier III, argint şi grafit. Iniţial, ţesătura a fost tratată prin tehnologiile clasice de fulardare (ignifugare), raclare şi, în final, prin procedeul avansat de imprimare digitală $3 D$ pentru depunerea filamentelor ESD. Pentru ignifugare, materialul textil a fost impregnat în soluţie de Aflamit $50 \%$ şi uscat la o temperatură de $120^{\circ} \mathrm{C}$ pentru 3 minute.

Cuvinte-cheie: compozit, textil, electroconductiv, rezistenţă, microparticule, senzori

\section{INTRODUCTION}

Multivariate regression is a method used to evaluate the relationship between more than one independent variable (predictors) and more than one dependent variable (responses).

$$
y_{1}, y_{2}, \ldots, y_{n}=f\left(x_{1}, x_{2}, \ldots, x_{m}\right)
$$

The multivariate linear regression is an extension of multiple linear regressions to analyze possible linear relationships between input and output variables [1]. However, this technique was used to explain the feasibility of two-way prediction by developing models for fiber and yarn and reverse models relating yarn to fiber using multivariate methods simultaneously [2] and to trace metals in textile effluents in relation to soil and groundwater [3]. In this paper, the multivariate analysis [4-7] is used to investigate the influence of the independent and dependent variables in the electroconductive textile development. In comparison with multiple regressions, where it is necessary, only one predictor and one response in a multivariate regression model are more than on predictors and more than one response [8].

The conductive textiles can be obtained by coating with organic conductive polymers such as polyaniline (PANI), polypyrrole (PPy), and polythiophene (PTh) derivatives [9-10]. The selection of the method to produce conductive textiles (yarns, fibers, fabrics) depends on the type of textile used to be coated, dimensions, and surface properties. However, the superior conductive composites can be obtained using coating dispersions based on carbon (carbon nanotubes (CNTs) or graphene). Besides, some researches indicate that the conductive surface can be obtained by coating graphene oxide onto traditional textiles (silk or polyamide) and followed by thermal reduction [11]. Another direction is on using the nonfunctionalized CNTs, with length over than $500 \mu \mathrm{m}$, 
mixed with an amino-functionalized sol-gel precursor for coating textile surfaces to obtain the textile composite with surface electrical resistance around $9.5 \times 10^{2}$ [12]. Concerning the ESD (Electrostatic discharge) or PLA (Polylactic acid) filament deposition on textile to obtain 3D composites, already exist several approaches adopted by researchers for dualmaterial fused filament fabrication for 3D printing electronic components and circuits with conductive thermoplastic filaments [13-15]. 3D printing technology of ESD/PLA filaments, made using cutting-edge multi-wall carbon nanotube technology [16], is cheap and very accessible to a broad public. However, the inconvenience in printing 3D ESD filaments comes from the low surface adhesion of rigid ESD or PLA filament [17] to the flexible textile surface. The non-uniform adhesion to the textile surface can generate real problems due to the temporary effect or low traction resistance on the warp, weft, and $45^{\circ}$ directions [21]. $3 \mathrm{D}$ printing of the polymer filaments directly on fabrics is a thermal welding method in which the polymer as an adhesive and textile material as an adherent are joining during the printing process [17-18]. The adhesion between textile and 3D filament can be influenced by the textile surface and temperature [17-18].

\section{EXPERIMENTAL PART}

In the experimental part there have been carried out experimental samples using cotton fabric (BBC) $100 \%$, polyamide (PA) 100\%, and polypropylene (PP) 100\%, with electroconductive properties and electromagnetic based on traditional technologies and 3D digital printing technology. In order to achieve the 28 samples functionalization experimental fabrics by submission of microbead particle of nickel (Ni), copper $(\mathrm{Cu})$, iron oxide II, III $\left(\mathrm{Fe}_{3} \mathrm{O}_{4}\right)$, silver $(\mathrm{Ag})$, graphite (C) and zinc $(\mathrm{Zn})$, have been used for the classic technologies implemented by padding (Flame Retardants), direct printing (polymeric pasta with a microbead particle of $\mathrm{Zn}, \mathrm{Cu}, \mathrm{Ni}, \mathrm{Fe}_{3} \mathrm{O}_{4}$, Ag, and Graphite), scraping, and advanced technology for submission by the $3 \mathrm{D}$ digital printing on the basis of the filaments ESD. For the flame retardants, the fabric has been impregnated in a solution of $50 \%$ Aflamit and dried at a temperature of $120^{\circ} \mathrm{C}$ for 3 minutes.

To obtain electroconductive properties there were used to print, the polymers, such as polyethylene glycol (PEG), polyvinyl alcohol (PVA), gelatine, and metallic microparticles (Ag, $\mathrm{Zn}, \mathrm{Fe}_{3} \mathrm{O}_{4}$, graphite $(\mathrm{C})$. In the experimental part, we developed 28 conductive fabrics through direct printing (direct printing and scraping) with paste based on water, binders (PEG and/or PVA) and microparticles of $\mathrm{Cu}$ (V1-Cu $<45$ $\mu \mathrm{m}$; V2-Cu < $75 \mu \mathrm{m})$; V3-Cu = 14-25 $\mu \mathrm{m}), \mathrm{Zn}, \mathrm{Fe}_{3} \mathrm{O}_{4}$, $\mathrm{Ni}(<50 \mu \mathrm{m}, \mathrm{Ag}(\mathrm{V} 1-\mathrm{Ag}<45 \mu \mathrm{m}$; V2-Ag = 2-3.5 $\mu \mathrm{m})$ and graphite $(\mathrm{C})$ followed by drying at a temperature of $19^{\circ} \mathrm{C}$ for 20 hours and the condensation for $3 \mathrm{~min}-$ utes for functionalization by increasing the static or electroconductive character. Table 1 presents the surface resistance (Rs [ $\Omega]$ ) and conductance (G [S])

SURFACE RESISTANCE AND CONDUCTANCE OF THE SAMPLES FUNCTIONALIZED BY PRINTING WITH A POLYMERIC PASTE BASED ON DIFFERENT METALLIC MICROPARTICLES

\begin{tabular}{|c|c|c|c|c|c|c|c|c|c|c|c|c|c|c|c|}
\hline Sample & $\mathrm{Ni}$ & $\begin{array}{l}\text { V1 } \\
\dot{\mathrm{Cu}}\end{array}$ & $\begin{array}{l}\text { v2 } \\
\dot{\mathrm{Cu}}\end{array}$ & $\begin{array}{l}\text { V3 } \\
\overline{\mathrm{Cu}}\end{array}$ & $\begin{array}{c}\text { V1 } \\
- \\
\overline{A g}\end{array}$ & $\begin{array}{c}\text { V2 } \\
\overline{\mathrm{Ag}}\end{array}$ & $Z n$ & $\mathrm{Fe}_{3} \mathrm{O}_{4}$ & Graphite & PEG & PVA & Gelatin & $\mathrm{H}_{2} \mathrm{O}$ & $\begin{array}{l}\text { Rs } \\
(\Omega)\end{array}$ & $\begin{array}{c}\text { G } \\
(\mathbf{S})\end{array}$ \\
\hline 1 & & & & & & & & & $x$ & $x$ & $x$ & & $x$ & $10^{11}$ & $10^{-11}$ \\
\hline 2 & & & & & & & & $x$ & & & $x$ & & $x$ & $10^{7}$ & $10^{-7}$ \\
\hline 3 & & & $x$ & & & & & & & & $x$ & & $x$ & $10^{12}$ & $10^{-12}$ \\
\hline 4 & $x$ & & & & & & & & & & $x$ & & $x$ & $10^{3}$ & $10^{-3}$ \\
\hline 5 & & & & $x$ & & & & & & & $x$ & & $x$ & $10^{7}$ & $10^{-7}$ \\
\hline 6 & & $x$ & & & & & & & & & $x$ & & $x$ & $10^{3}$ & $10^{-3}$ \\
\hline 7 & & & & & $x$ & & & & & & $x$ & & $x$ & $10^{8}$ & $10^{-8}$ \\
\hline 8 & & & & & & $x$ & & & & & $x$ & & $x$ & $10^{3}$ & $10^{-3}$ \\
\hline 9 & & & & & & & $x$ & & & & $x$ & & $x$ & $10^{12}$ & $10^{-12}$ \\
\hline 10 & $x$ & & & & & & & & & & $x$ & & $x$ & $10^{3}$ & $10^{-3}$ \\
\hline 11 & & $x$ & & & & & & & & & $x$ & & $x$ & $10^{4}$ & $10^{-4}$ \\
\hline 12 & & & & & & $x$ & & & & & $x$ & & $x$ & $10^{3}$ & $10^{-3}$ \\
\hline 13 & & $x$ & & & & & & & & & $x$ & $x$ & $x$ & $10^{4}$ & $10^{-4}$ \\
\hline 14 & & & $x$ & & & & & & & & $x$ & $x$ & $x$ & $10^{9}$ & $10^{-9}$ \\
\hline 15 & & & & & & $x$ & & & & & $x$ & $x$ & $x$ & $10^{3}$ & $10^{-3}$ \\
\hline 16 & & & & & & & & $x$ & & & $x$ & $x$ & $x$ & $10^{7}$ & $10^{-7}$ \\
\hline 17 & & & & $x$ & & & & & & & $x$ & $x$ & $x$ & $10^{10}$ & $10^{-10}$ \\
\hline 18 & & & & & & & & $x$ & & & $x$ & $x$ & $x$ & $10^{8}$ & $10^{-8}$ \\
\hline
\end{tabular}


for samples. In table 1, for samples 21-28 it has been used the same type of conductive paste based of PVA, $\mathrm{H}_{2} \mathrm{O}$ and Ni microparticles but it has been used different textile support such as: for samples 21-22 has been used in a BBC fabric of $100 \%$, for samples 23-24 there have been used fabrics of PA $100 \%$ and samples $27-28$ has been made using 100\% PP fabric. In the case of samples 21-28, changing the fiber composition of textile support has not influenced the conductivity or resistance to the surface, for the first 8 samples Rs being approximately $1 \times 10^{3}-1.1 \times 10^{3} \Omega$. For the first 9 experimental samples there have been investigated the rubbing (dry and wet wetting 69\%, the frictional force $9 \mathrm{~N}$ ) parallel to the warp direction in accordance with SR EN ISO 105-x12/2016 (table 2).

Table 2

\begin{tabular}{|c|c|c|c|c|}
\hline \multicolumn{5}{|c|}{ RESISTANCE TO DRY/WET RUBBING } \\
\hline Sample & $\begin{array}{c}\text { Metal } \\
\text { release } \\
\text { after dry } \\
\text { rubbing }\end{array}$ & $\begin{array}{c}\text { Metal } \\
\text { release } \\
\text { after wet } \\
\text { rubbing }\end{array}$ & $\begin{array}{c}\text { Resistance } \\
\text { to dry } \\
\text { rubbing }\end{array}$ & $\begin{array}{c}\text { Resistance } \\
\text { to wet } \\
\text { rubbing }\end{array}$ \\
\hline 1 & - & - & - & - \\
\hline 2 & 0.016 & 0.071 & 2 & 1 \\
\hline 3 & - & 0.3728 & - & $2-3$ \\
\hline 4 & 0.0015 & 0.0034 & $3-4$ & 3 \\
\hline 5 & 0.001 & 0.0071 & $4-5$ & 2 \\
\hline 6 & 0.0024 & 0.004 & $4-5$ & 3 \\
\hline 7 & 0.0022 & 0.0044 & $4-5$ & $4-5$ \\
\hline 8 & 0.002 & 0.0057 & $4-5$ & $3-4$ \\
\hline 9 & 0.0033 & 0.0078 & 4 & $1-2$ \\
\hline
\end{tabular}

The numeric values of physicomechanical parameters such as thickness $\delta(\mathrm{mm})$, the mass $M\left(\mathrm{~g} / \mathrm{m}^{2}\right)$, the permeability to air $\mathrm{Pa}\left(1 / \mathrm{m}^{2} / \mathrm{s}\right)$, the surface resistance $R s(\Omega)$ for 9 samples experimentally evaluated are presented in table 3 .

For the demonstration of the morphological changes which appear on the cotton fibers presented in table 4 there was analyzed the surface of the fabric using electron microscopy scanning with magnification X2000 for conductive samples (4, 6, 8, 0-initial) and samples treated with sweat acid, alkaline, respectively. Figure 1 presents the topographic analysis of the surface of the textiles on the basis of the electronic microscopy magnification $(4 \times)$, the surface of the initial

\begin{tabular}{|c|c|c|c|c|}
\hline \multicolumn{5}{|c|}{ SAMPLES 1-9 PHYSICO-MECHANICAL } \\
PARAMETERS \\
\hline Sample & $\begin{array}{c}\mathbf{M} \\
\left(\mathbf{g} / \mathbf{m}^{2}\right)\end{array}$ & $\begin{array}{c}\boldsymbol{\delta} \\
(\mathbf{m m})\end{array}$ & $\begin{array}{c}\text { Pa } \\
\left(\mathbf{I} / \mathbf{m}^{2} / \mathbf{s}\right)\end{array}$ & $\begin{array}{c}\text { Rs } \\
(\mathbf{\Omega})\end{array}$ \\
\hline 1 & 709 & 0.97 & 5.755 & $10^{11}$ \\
\hline 2 & 515 & 1.011 & 4.31 & $10^{7}$ \\
\hline 3 & 752 & 4.385 & 16.8 & $10^{12}$ \\
\hline 4 & 556 & 1.527 & 8.876 & $10^{3}$ \\
\hline 5 & 650 & 1.847 & 6.123 & $10^{7}$ \\
\hline 6 & 658 & 1.304 & 4.27 & $10^{3}$ \\
\hline 7 & 476 & 1.317 & 3.88 & $10^{8}$ \\
\hline 8 & 586 & 1.894 & 5.656 & $10^{3}$ \\
\hline 9 & 741 & 3.552 & 11.56 & $10^{12}$ \\
\hline
\end{tabular}

fabric (without metal content microparticle) (figure 1, a) and the surface of the fabrics microparticle of $\mathrm{Ni}$ (sample 4), Cu (sample 6) and the sample Ag (sample 8) (figure 1,b to $d$ ).

\section{RESULTS AND DISCUSSION}

The multivariate regression used to analyze the resistance and the thickness $(\delta)$, air permeability $(P a)$, and mass $(M)$. The value of multiple correlation $R$ is 0.944 (very close to 1 ), which means that is a strong positive relationship between $R s$ and $P a, \delta$, and $M$. In figures 2-5 are presented the 3D representations of the electrical resistance $(R s)$ in the function of the thickness $(\delta)$, mass $(M)$, air permeability $(P a)$, and resistance $(G)$ using MATLAB software.

For experimental parameters $(R s, M, \delta, P a)$ was performed an analysis of the correlation coefficient Pearson (2) between $R s$ and $P a, \delta, M$ :

$$
r_{x y}=\frac{\frac{1}{n} \sum(x-\bar{x})(y-\bar{y})}{s_{x} s_{y}}
$$

where $x, y$ represent the individual values of the variables $x$ and $y ; \bar{x}, \bar{y}$ represent the arithmetic mean of all the values of $x, y ; s_{x}, s_{y}$ represent the standard deviation of all values $x$ and $y$.

Analyzing the values of the correlation coefficients $r_{R_{s} P_{a}}(3), r_{R_{s} \delta}(4), r_{R_{s} M}(5)$, and $r_{R_{s} G}(6)$, it can be observed that between the surface resistance $(R s)$ and air permeability $(P a)$, mass $(M)$, thickness $(\delta)$ it is a positive direct proportionality relationship, and this indicate that an increase of the surface resistance

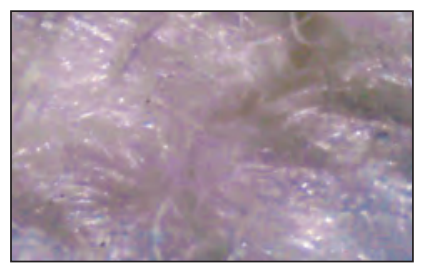

a

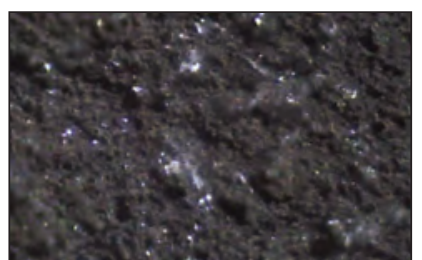

b

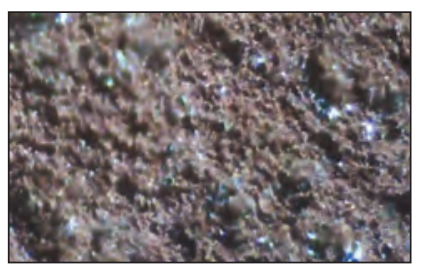

c

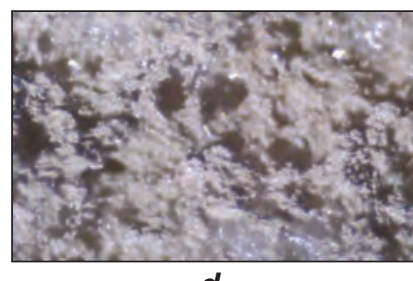

d

Fig. 1. Topographic analysis of the fabric surface based on electronic microscopy: a - fabric without microparticles submitted; $b$-sample no. $4 ; c$ - sample no. $6 ; d$-sample no. 8 


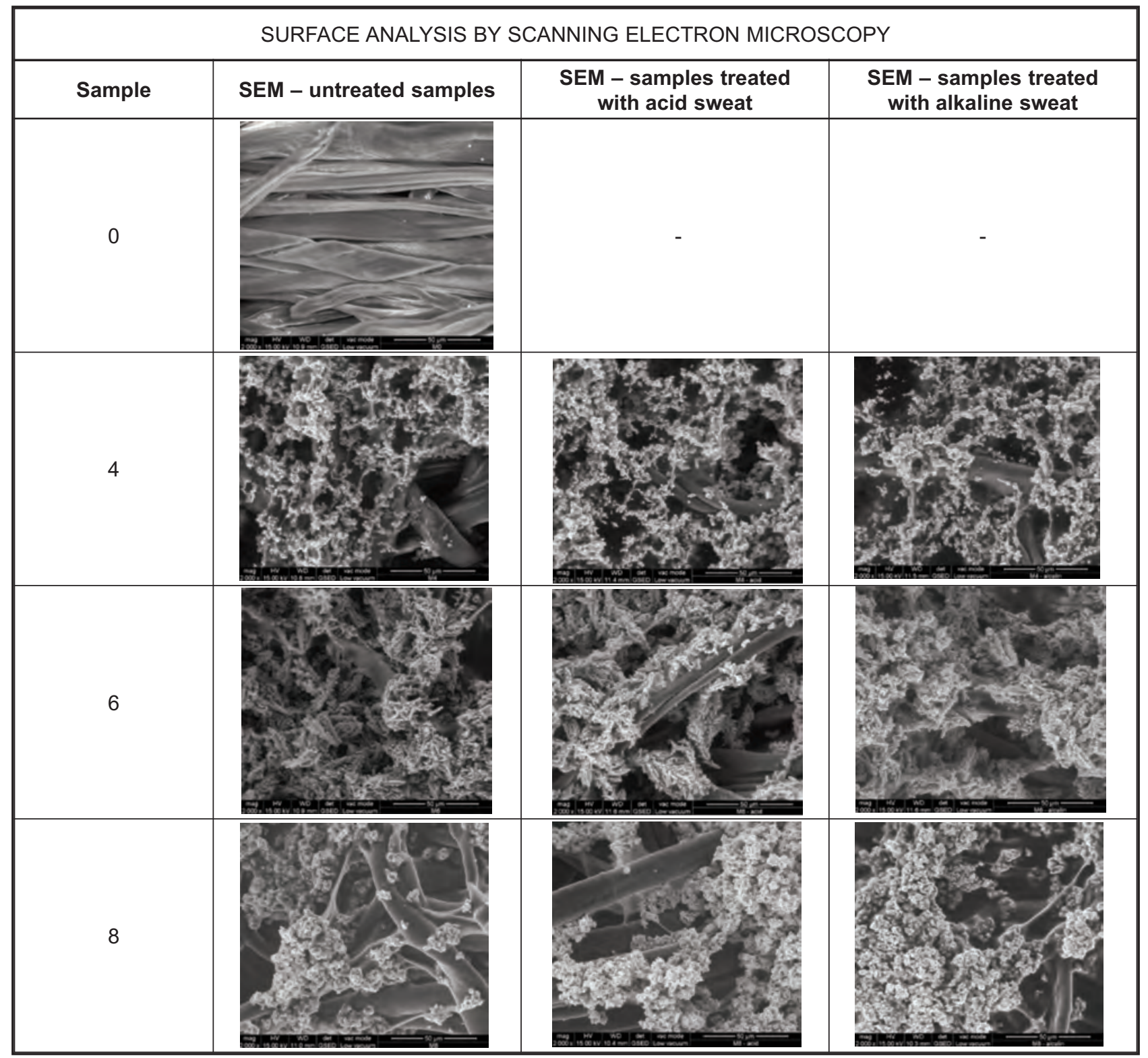

value can be generated through-thickness increasing, mass, and air permeability. Because the electrical resistance is inverse proportional with the electrical conductance (6), this means that higher air permeability leads to decreasing the conductivity, because of lower yarns density on weft or warp will not allow an excellent electrical conductivity.

This means that the increase of mass, air permeability, and thickness values determine an increase of the surface resistance values and by default, a decreasing of the values for conductance.

$$
\begin{aligned}
& r_{R_{s} P_{a}}=\left|\begin{array}{ll}
1.0000 & 0.8866 \\
0.8866 & 1.0000
\end{array}\right| \\
\Leftrightarrow & r 12_{R_{s} P_{a}}=r 21_{R_{s} P_{a}}=0.8866 \\
& r_{R_{s} \delta}=\left|\begin{array}{ll}
1.0000 & 0.9343 \\
0.9343 & 1.0000
\end{array}\right| \\
\Leftrightarrow & r 12_{R_{s} \delta}=r 21_{R_{s} \delta}=0.9343
\end{aligned}
$$

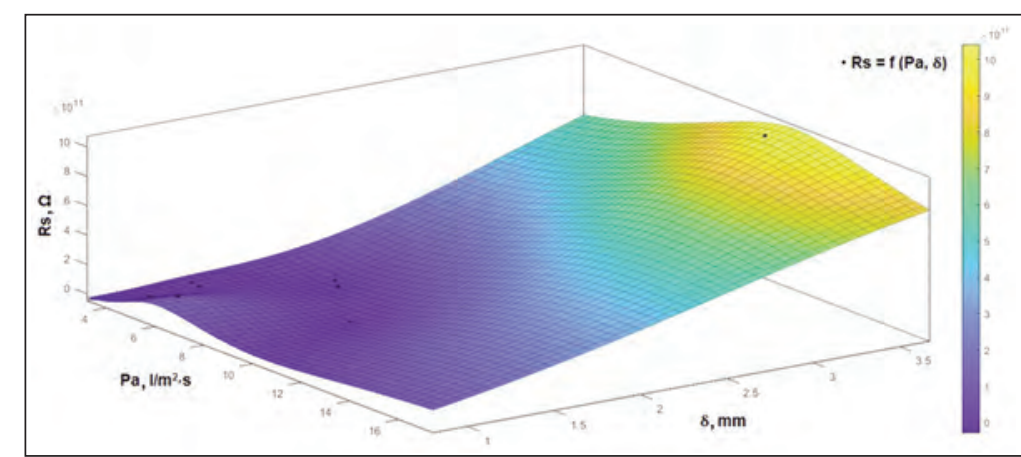

Fig. 2. 3D representation of the surface resistance according to the air permeability $(\mathrm{Pa})$ and thickness $(\delta)$ $(R s=f(P a, \delta))$

$$
\Leftrightarrow r 12_{R_{s} G}=r 21_{R_{s} G}=-0.4016
$$




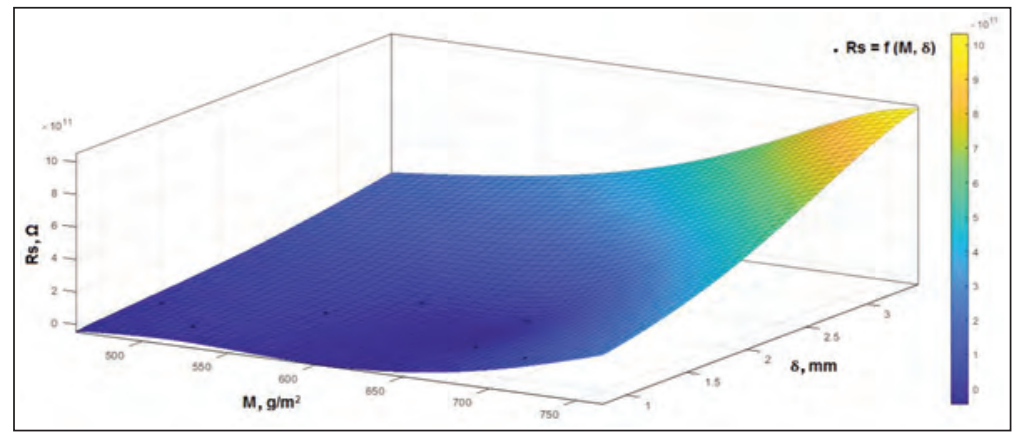

Fig. 3. 3D representation of the surface resistance (Rs) according to the mass $(\mathrm{M})$ and thickness $(\delta)$

$(R s=f(M, \delta))$

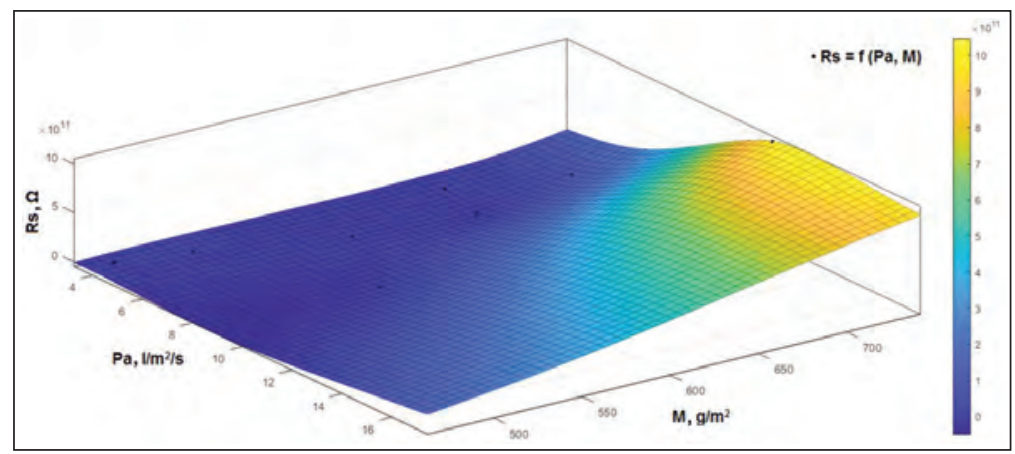

Fig. 4. 3D representation of the surface resistance (Rs) according to the air permeability $(\mathrm{Pa})$ and mass $(\mathrm{M})$ $(R s=f(P a, M))$

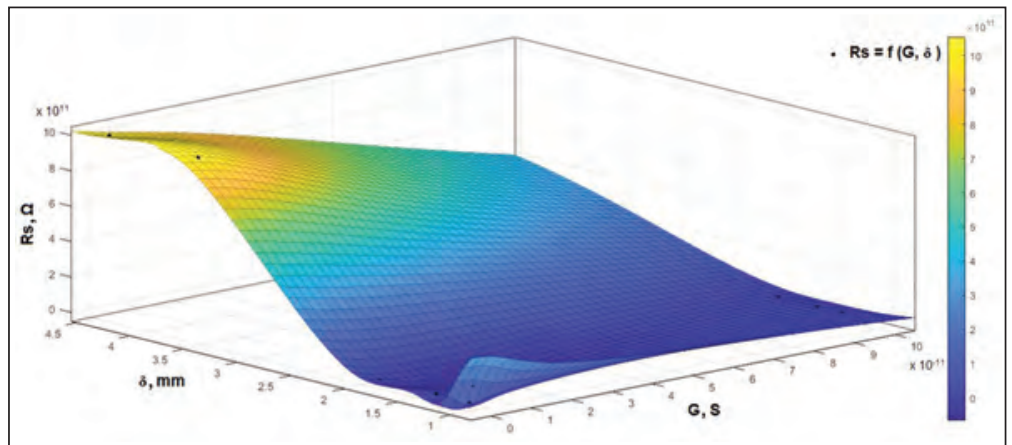

Fig. 5. 3D representation of the surface resistance (Rs) according to the thickness $(\delta)$ and conductance $(G)$

$(R s=f(\delta, G))$

\section{CONCLUSIONS}

For samples 4, 6, 8, 10-13, 15 and 20-28 it is evident that the surface resistance values are specific to the conductive materials $\left(10^{1}-10^{5} \Omega\right)$, and in case of the samples 2 , and 16 the surface resistance has the value $(R s=$ $10^{7} \Omega$ ) specific to static dissipative materials $\left(10^{6}-10^{12} \Omega\right)$.

Based on the analysis of the Pearson correlation coefficient, it can be concluded that mass, thickness, and air permeability are in a directly proportional relationship with the surface resistance and in an indirect proportionality relationship with the electrical conductivity. Due to the fact that the electrical resistance is inversely proportional to the electrical conductivity, it means that the increase of the air permeability, the mass, and the thickness will contribute to the decrease of the conductivity because on case of the fabrics with low density of yarns on warp and weft direction practically the concentration of metallic microparticles on the textile surface decreases and the electrical conductance will be reduced.

\section{ACKNOWLEDGEMENTS}

The research presented in this paper was prepared in the INCDTP laboratories. Funds support this work from $\mathrm{MCl}$, National Project "Materiale textile composite electroconductive pe bază de matrici polimerice $3 \mathrm{D}$ pentru sisteme senzoriale de monitorizare şi de atenuare a undelor electromagnetice (3D ELECTROTEX)", Contract PN 19170101.

\section{REFERENCES}

[1] Izenman, A.J., Multivariate regression, In Modern Multivariate Statistical Techniques, Springer, New York, NY, 2013 , 159-194

[2] Fattahi, S., Ravandi, S.A.H., Taheri, S.M., Two $\square$ way prediction of cotton yarn properties and fiber properties using multivariate multiple regression, In: Journal of the Textile Institute, 2011, 102, 10, 849-856

[3] Manzoor, S., Shah, M.H., Shaheen, N., Khalique, A., Jaffar, M., Multivariate analysis of trace metals in textile effluents in relation to soil and groundwater, In: Journal of Hazardous Materials, 2006, 137, 1, 31-37

[4] Chamberlain, G., Multivariate regression models for panel data, In: Journal of econometrics, 1982, 18, 1, 5-46

[5] Zhang, X., Shi, X., Sun, Y., Cheng, L., Multivariate Regression with Gross Errors on Manifold-Valued Data, In: IEEE transactions on pattern analysis and machine intelligence, 2018, 41, 2, 444-458

[6] Chatfield, C., Introduction to multivariate analysis, Routledge, 2018

[7] Bing, X., Wegkamp, M.H., Adaptive estimation of the rank of the coefficient matrix in high-dimensional multivariate response regression models, In: The Annals of Statistics, 2019, 47, 6, 3157-3184

[8] Stockemer, D., Multivariate Regression Analysis, In: Quantitative Methods for the Social Sciences, Springer, 2019, 163-174

[9] Grancarić, A.M., Jerković, I., Koncar, V., Cochrane, C., Kelly, F.M., Soulat, D., Legrand, X., Conductive polymers for smart textile applications, In: Journal of Industrial Textiles, 2018, 48, 3, 612-642 
[10] Fu, K.K., Padbury, R., Toprakci, O., Dirican, M., Zhang, X., Conductive textiles, In: Engineering of HighPerformance Textiles, 2017, 305

[11] Zulan, L., Zhi, L., Lan, C., Sihao, C., Dayang, W., Fangyin, D., Reduced Graphene Oxide Coated Silk Fabrics with Conductive Property for Wearable Electronic Textiles Application, In: Advanced Electronic Materials, 2019, 5, 4, 1800648

[12] Trovato, V., Teblum, E., Kostikov, Y., Pedrana, A., Re, V., Nessim, G., Rosace, G., Designing of carbon nanotubes/cotton fabric composite for e-textiles: effect of carbon nanotubes length on electroconductive properties, In: Autex 2019: Textiles at the crossroads, 2019, 1-6

[13] Flowers, P.F., Reyes, C., Ye, S., Kim, M.J., Wiley, B.J., 3D printing electronic components and circuits with conductive thermoplastic filament, In: Additive Manufacturing, 18, 2017, 156-163

[14] Valino, A.D., Dizon, J.R.C., Espera Jr, A.H., Chen, Q., Messman, J., Advincula, R.C., Advances in 3D printing of thermoplastic polymer composites and nanocomposites, In: Progress in Polymer Science, 2019, 101162

[15] Bafleur, M., Caignet, F., Nolhier, N., ESD Protection Methodologies: From Component to System, Elsevier, 2017

[16] Kauppinen, E., Brown, D.P., Nasibulin, A.G., Jiang, H., Motta, A.M., Canatu Oy, Single, multi-walled, functionalized and doped carbon nanotubes and composites thereof, U.S. Patent 9,556,032, 2017

[17] Sanatgar, R.H., Campagne, C, Investigation of the adhesion properties of direct 3D, In: Microwaves, 2013, 7, 760-767

[18] Sanatgar, R.H., Campagne, C., Nierstrasz, V., Investigation of the adhesion properties of direct 3D printing of polymers and nanocomposites on textiles: Effect of FDM printing process parameters, In: Applied Surface Science, $2017,403,551-563$

\section{Authors:}

RALUCA MARIA AILENI, SILVIA ALBICI, LAURA CHIRIAC, IRINA-MARIANA SĂNDULACHE

National Research \& Development Institute for Textiles and Leather, 16 Lucretiu Patrascanu Street, 030508, Bucharest, Romania e-mail: silvia.albici@incdtp.ro; laura.chiriac@incdtp.ro; irina.sandulache@incdtp.ro

\section{Corresponding author:}

\section{RALUCA MARIA AILENI}

e-mail: raluca.aileni@incdtp.ro 


\title{
Quality inspection and prediction of the comfort of fabrics finished with functional polymers
}

\author{
DOI: $10.35530 / I T .071 .04 .1734$
}

\section{ABSTRACT - REZUMAT}

Quality inspection and prediction of the comfort of fabrics finished with functional polymers

Textile's primary hand (HV) and total hand values (THV) are very important parameters and are used to identify the quality of clothing comfort. This paper aims to predict the HV and THV of the fabrics finished with functional polymers by applying Kawabata's translation equations. The mechanical properties were achieved using Kawabata's fabric evaluation system (KES-F) and the inference/interpretation was drawn. Then, HV and THV predictions were performed by applying Kawabata's translation equations of the KN-101 and KN-301 series. The KES-F result confirmed that it is possible to observe the operative finishing effect on the mechanical properties of fabrics. The prediction results show that the total quality comfort of the functional fabrics could able be estimated by the equation developed by Kawabata; the calculated errors ( 0.66) were within the range of the standard deviations ( 0.78) of the samples between the predicted and ranked THV. The experimental and the calculated primary hand values showed strong correlation coefficients up to $\sim 0.98$ which is significant at 0.001 confidence levels. As actual functional fabrics with various surface properties were provided to estimate their tactile comfort via the equations, the result verified that the equation is reliable for the tactile comfort evaluation and grading.

Keywords: translation equations, THV, low-stress mechanical properties, tactile comfort, polymer

\section{Evaluarea calității și predicția confortului senzorial în cazul purtării materialelor textile finisate cu polimeri funcționali}

Tușeul materialelor textile (HV) și indicele total de tușeu (THV) sunt parametri foarte importanți pentru evaluarea calității produselor de îmbrăcăminte din punctul de vedere al confortului la purtare. Lucrarea are ca scop propunerea unei metodologii de predicție a HV și THV pentru materiale textile tratate cu polimeri funcționali, prin utilizarea ecuațiilor tranzitorii Kawabata. Proprietățile mecanice ale materialelor textile au fost determinate prin utilizarea unui sistem Kawabata (KES-F) și s-a realizat prelucrarea/interpretarea acestora. Predicția valorilor HV și THV a fost realizată prin utilizarea ecuatiilor tranzitorii Kawabata, seriile KN-101 și KN-301. Rezultatele testelor efectuate pe KES-F au evidențiat influența tratamentelor de finisare asupra proprietăților mecanice ale materialelor textile analizate. Rezultatele predicției au demonstrat că asigurarea confortului la purtarea materialelor funcționale poate fi estimată prin ecuațiile dezvoltate de Kawabata; eroarea calculată $(\sim 0,66)$ se încadrează în intervalul abaterii standard $(\sim 0,78)$ pentru materialele analizate, între valoarea previzionată și cea determinată a THV. Corelația dintre valoarea determinată experimental a indicelui de tușeu (HV) și cea calculată este puternică, demonstrată prin valoarea coeficientului de corelație de aproximativ 0,98, semnificativ pentru un nivel de încredere de 0,001. Rezultatele obținute pentru materialele textile cu finisări funcționale analizate arată că ecuațiile utilizate pentru modelare sunt adecvate pentru evaluarea și ierarhizarea confortului senzorial.

Cuvinte-cheie: ecuații tranzitorii, THV, solicitări mecanice de intensitate mică, confort senzorial, polimer

\section{INTRODUCTION}

Recent research progresses in the wearable e-textile applications have witnessed exciting improvement of the use of the functional fabrics finished with conductive polymers such as wearable electronics textiles [1], textile-based strain sensors [2-4], wearable selfpowered textile electronics [5], electrically-conducting textiles [6], wearable and flexible electroluminescence devices [7]. However, the assessment of these electronic textiles with respect to comfort aspect has little or no exploration has been performed. The comfort issue could be inspected by estimating the primary and the total hand values of the wearable textiles from its mechanical properties [8]. In predicting the HV and THV of the materials, it's presumably to assess the tactile comfort of the textile product.

Tactile/sensorial comfort is the combined results of the interaction between the wearer's skin, the clothing materials, and the environment [9]. It is one of the straightforward performance parameters for the inspection of comfort quality of clothes intended for wearing. Wearable e-textiles have a direct contact with the skin of the user and hence the tactile comfort of these fabrics shall be investigated. Tactile comfort has a strong association with the mechanical properties of clothing goods measured under low-region conditions [10-14]. In addition, the subjectively measured, quality index assessed by human experts, and 
the objectively measured mechanical properties have been applied to optimize the fabric properties as mentioned in [15]. Linen fabrics subjected to various finishing as well as blended with other fibers have been investigated for its ease using KES-F [16]. However, standard fabrics touch the whole body parts while functional fabrics may or may not touch the whole body parts. That is why this paper intended to find if there is mandatory or is there any difference between the standard and functional fabrics comfortable property prediction when applying the same equations.

The KES is the primary system that does not only foresee the human sensory perception but also figuring out the sensitivity of the tactile properties of the fabrics. In the 1980s, Kawabata and his co-workers [17] established the Kawabata's evaluation system (KES-F), a sophisticated and reliable tool to measure the low-stress mechanical properties of (tensile, shearing, bending, compression, thickness, weight, surface, and frictional) various kinds of fabrics. The KES system that was initially designed for the objective evaluation of textile-based goods under low-load regions enables a precise measurement which is sufficient for the quality inspection of textile-based materials and further used to the quality assurance and design development purpose. Kawabata and his coworkers derived translations of equations capable to calculate the quality of wearable textiles in terms of primary hand and total quality index including men's suiting fabrics. Some researchers have been used the translation equations (man's winter suit) developed by Kawabata for the prediction of handle values of various kinds of clothing materials such as futon cloth [18], terry fabrics [19], blankets [20], non-woven [21], and toilet papers [22]; with slight adjustments and they found promising outcomes. This encourages the idea of deriving the quality of fabrics finished with functional polymers to use the Kawabata's translation equations that have been applied to predict the quality of men's winter suiting fabrics.

In this paper, Kawabata translation equations (KN-101 series) were applied to predict the primary hand and the total hand value of the functional fabrics. The lowstress mechanical properties were inferred and used as input parameters to predict the hand factors. First, the mechanical properties were converted into the primary hand values (HV) using the $\mathrm{KN}-101$ equation, then the tactile quality of the functional fabric was derived from the HV, using the equation $\mathrm{KN}-301$. The prediction was performed based on the assumption that functional fabrics have the comparable sensorial perception to that of men's winter suit. With the clue provided by the data chart and the prediction results, it could be possible to attain the persuasive connection and communication between various stakeholders such as researchers, quality controllers, manufacturers, and traders of the functional and smart textile industries by giving specified quality parameters and specifications of the quality of smart fabric production.

\section{MATERIALS AND METHODS}

\section{Preparations of functional fabrics}

A woven polyester fabric that have a weight of 158 $\mathrm{g} / \mathrm{m}^{2}, 30$ ends $\mathrm{cm}^{-1}, 22$ picks $\mathrm{cm}^{-1}$, and scoured and heat-set by the supplier (Almedahl-Kinna AB, Sweden) as the substrate (sample 7) used to produce five different functional fabrics as follows:

The photochromic sample (sample 1) was prepared using inkjet printing tools (a Sapphire QS 10 print head from Fujifilm Dimatix, USA). A commercial heterocyclic Spiro-compound (Reversacol Ruby Red) photochromic dye from Vivimed Labs with a concentration of $2.5 \mathrm{~g} / \mathrm{l}$; a varnish which entails dipropylene glycol diacrylate monomer, amine modified polyether acrylate oligomers (Ebecryl 81) from Allnex SA/NV, Belgium and a photo-initiator (Genocure TPO-L) from Rahn AG, Switzerland were used to prepare the inkjet printing to achieve a surface tension of $30 \mathrm{mN} / \mathrm{m}$ and a viscosity of $10.6 \mathrm{mPa} \cdot \mathrm{s}$ at $20^{\circ} \mathrm{C}$ and $10000 \mathrm{~s}^{-1}$. After preparing the printing solution, printing was carried out at a resolution of 300 dpi with a print head temperature of $35^{\circ} \mathrm{C}$ for 10 layers and the recipe was prepared as per [23]. Finally, the sample was cured using UV-LED light at $30 \%$ intensity. The final sample had a CIE DE (color space) value of $2.74 \pm 0.583$.

Conductive sample (sample 4) was prepared using similar inkjet printing machine and the same printing parameters as of sample 1 . The poly (3, 4-ethylenedioxythiphene): poly (styrene sulfonate) (PEDOT-PSS) - a conductive polymer (Heraeus $\mathrm{GmbH}$, Germany) with a concentration of $1.3 \%$ by weight; and a PSS to PEDOT ratio of 2:5 was used as the conductive agent. A glycerol (from Sigma Aldrich) in deionized water $(6: 4 \mathrm{w} / \mathrm{w})$ was used to optimize the rheology of inkjet inks. The final ink had a rheology of $29 \mathrm{mN} / \mathrm{m}$ and viscosity of $\sim 14 \mathrm{mPa} \cdot \mathrm{s}$ at $20^{\circ} \mathrm{C}$ and $1000 \mathrm{~s}^{-1}$. The printing process was performed for 50 layers. Then, the sample was dried at $100^{\circ} \mathrm{C}$ for 15 minutes and cured at $150^{\circ} \mathrm{C}$ for 10 minutes. The surface resistance of the sample was $0.168 \pm 0.013 \mathrm{k} \Omega \square^{-1}$. Conductive specimen (sample 5) was prepared by coating techniques using PEDOT-PSS as a conductive polymer, dimethyl sulfoxide (98\%) (DMSO) $(5 \%)$ from Sigma Aldrich as a conductive enhancer, U2101 from Alberdingk Boley with a viscosity of $\sim 100 \mathrm{cps}$ and weight of $\sim 60 \mathrm{wt} \%$ as a binder, and hydrophobically modified ethoxylated urethane symbolized by Gel L75N ( Borchers GmbH) having 48 wt\% as a rheology modifier were used to prepare the coating paste. The paste was thoroughly mixed using an overhead mechanical mixer at a speed of $800 \mathrm{rpm}$ until it became homogeneous with the naked eye. The coating was performed with a manual coating applicator with adjustable height at $200 \mu \mathrm{m}$ gap distance to the substrate materials. Finally, the sample was dried at $90^{\circ} \mathrm{C}$ for 30 minutes and cured at $150^{\circ} \mathrm{C}$ for 3 minutes. The surface resistance value was 7.98 $\pm 0.969 \Omega \square^{-1}$.

Conductive specimen (sample 6) was prepared using manual screen printing machine with a polyester mesh of size 70 . The printing was performed to-and-fro 
motion three times to bring a dark shade. The chemicals and the pre- and post-preparation techniques were similar to that of sample 5 as mentioned above. The surface resistance was $4.41 \pm 0.396 \Omega \square^{-1}$.

Thermochromic specimen (sample 9) was prepared using manual screen printing techniques with the same principle to that of sample 6 mentioned above. A Variotherm $A Q$ thermochromic ink $(5 \%)$ with an activation temperature of $32^{\circ} \mathrm{C}$ and a ChromaZone reversible based extender (binder) (95\%) from Zenit, Sweden were used to prepare the printing pastes. The sample was then cured at $170^{\circ} \mathrm{C}$ for 7 minutes to produce a sample having a color space (CIE DE) value of $54.07 \pm 2.48$.

\section{Subjective evaluation of fabrics}

Total hand value for each specimen was evaluated by ten trained panels of experts who were recruited taken into account their voluntariness and professional background. The experts were first brainstormed to be aware about tactile descriptors and ranking scales for the subjective evaluation. The subjects ranked the samples by touching and gripping the fabrics using a five-point scale; from 1 (very uncomfortable) to 5 (very comfortable). The subjects assess the sample both in blind touch and visual touch scenarios; the average was recorded. The mean scores of 10 assessors was reported as THVSub (subjective total hand value) and compared with the experimental data obtained by experimental THV (THV-KES) and calculated THV (THV-Cal) values obtained using the translation equation $\mathrm{KN}-301$. The procedures of the subjective evaluation of the specimens found in our previous work [24].

Objective evaluation of fabrics

The mechanical properties of tensile, shear, bending, compression, surface, and frictional for the functional fabrics were measured under low-load regions using tensile and shear tester (KES-F1), bending tester (KES-F2), compression tester (KES-F3), surface and friction tester (KES-F4) using an instrument called KES FB-Auto (KATO TECH CO., LTD). All the lowstress mechanical properties were measured in both the warp and the weft directions excluding the compressional property; the average was reported. The details of the mechanical properties are shown in table 1.

\section{RESULTS AND DISCUSSION}

Functional fabrics were prepared employing different functional polymers and methods in order to have diverse functionalities and physical and surface properties. Meanwhile, samples have been evaluated subjectively for its total hand values and objectively for its low-stress mechanical properties that could be further used to predict its primary and total and values using predicting equations. The overall assumption for the intended use of the functional fabrics is to use as a raw material for the production of men's winter suiting fabric. Each sub-section explained taken into account the above mentioned understanding and assumption.

\section{Effect of functional finishing using polymers on mechanical properties}

Figure 1 demonstrates 15 mechanical properties of the functional and control samples measured under low-load regions using KES-F under the test conditions used in [17]. The samples are produced using different state of the art technologies and sample 7 (control sample) is included for comparison purposes. A greater difference was found in shearing properties especially in the shear rigidity $\mathrm{G}$ and shear hysteresis at $0.5^{\circ}$ shear angle when observed visually from

\begin{tabular}{|c|c|c|}
\hline \multicolumn{3}{|c|}{ MECHANICAL AND SURFACE PROPERTIES [17] } \\
\hline Parameters & Properties & Description of mechanical properties \\
\hline \multirow{4}{*}{ Tensile } & EMT (\%) & The elongation, the strain at $500 \mathrm{gf} / \mathrm{cm}$ \\
\hline & LT & The linearity of load-extension curve \\
\hline & WT $\left(\mathrm{gf} \cdot \mathrm{cm} / \mathrm{cm}^{2}\right)$ & The tensile energy recorded per unit area \\
\hline & RT $(\%)$ & The tensile resilience, recovery from tensile deformation \\
\hline \multirow{2}{*}{ Bending } & $B(\mathrm{gf} / \mathrm{cm} \cdot \mathrm{deg})$ & Bending rigidity, the average slope of the linear regions \\
\hline & $2 \mathrm{HB}(\mathrm{gf} \cdot \mathrm{cm} / \mathrm{cm})$ & Bending hysteresis average width at $\pm 0.5 \mathrm{~cm}^{-1}$ curvature \\
\hline \multirow{3}{*}{ Shear } & $\mathrm{G}[\mathrm{gf} / \mathrm{cm} \cdot \mathrm{deg})$ & The shear rigidity, the average slope of the linear region to $\pm 2.5^{\circ}$ shear angle \\
\hline & $2 \mathrm{HG}(\mathrm{gf} / \mathrm{cm})$ & Shear hysteresis at average width at $0.5^{\circ}$ shear angle \\
\hline & 2HG5 (gf/cm) & Shear hysteresis average widths at $5^{\circ}$ shear angle \\
\hline \multirow{3}{*}{ Compression } & LC & The linearity of Compression-thickness curve \\
\hline & WC $\left(\mathrm{gf} \cdot \mathrm{cm} / \mathrm{cm}^{2}\right)$ & The compressional energy per unit area \\
\hline & $\mathrm{RC}(\%)$ & The compressional resilience; recovering ability \\
\hline \multirow{3}{*}{ Surface friction } & MIU & The coefficient of fabric surface friction \\
\hline & MMD & The mean deviation of MIU \\
\hline & $\operatorname{SMD}(\mu \mathrm{m})$ & The geometrical roughness \\
\hline
\end{tabular}




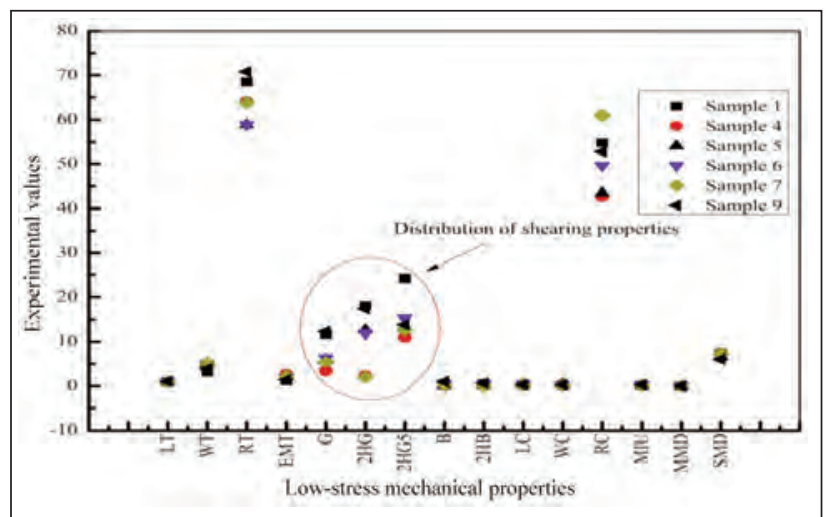

Fig. 1. Tensile, shearing, bending, compression, and surface friction properties as measured using KES-FB

the graph. Sample 9 attains rigidity $\mathrm{G}$ value of 12.25 $\mathrm{g} / \mathrm{cm} \cdot \mathrm{deg}$; more than 2 times with the control sample and more than 3.5 times to the sample with the lowest stiffness value. In addition, sample 1 achieves a bending hysteresis $2 \mathrm{HB}$ value of $0.659 \mathrm{gf} \cdot \mathrm{cm} / \mathrm{cm}$; more than 6 times with the sample having the best recoverability and more than 2.5 times than the control sample. Apparently, the inkjet-printing sample prepared using PEDOT-PSS plays a critical role in producing the best flexible and recoverable (resilient) sample. Likewise, the work of compression WC (an indication of softness obtained during sensory evaluation) and mean coefficient of friction MMD attain a difference of $\approx 60$ and $\approx 12 \%$, respectively between the most and least fabrics with compressional and frictional properties. The above piece of information indicates that the functional finishing and the use of different chemicals influence the stiffness and the softness of the samples.

On the other hand, sample 9 attains a tensile linearity value of $\sim 1.033$ (as the value came close to 1 , the sample becomes tougher and harder) which surpasses 1.2 times to that of the control sample and 1.3 to that of the sample with the least tensile linearity (sample 4). These values assured that functional finishing influences the tensile linearity of the curve only to some level. The KES evaluation results confirmed that the functional finishing using various polymers brought different and physico-sensorial perceptions that may influence the overall quality index of the wearable textiles.

\section{Interpreting the quality} control chart for quality inspection

The processability and tailorability control chart were first demonstrated by
Kawabata and his co-workers in 1980 [17]. The hand evaluation and standardization committee (HESC) introduced the data chart for considering the property of the fabric by plotting its low-stress mechanical measured by KES. For demonstration purpose, we interpret the data chart for only one functional fabric including the control sample for comparison purposes. Figure 2 illustrates the data chart for the lowstress mechanical properties of the fabrics in which the common scale is the scale normalized by the standard deviation $=(X-\bar{X}) / \sigma$. The functional fabric was produced using $1 \%$ PEDOT-PSS mixed with $6: 4$ $\mathrm{w} / \mathrm{w}$ ratio of glycerol in water with a resolution of 300 dpi. The polyester samples were used to produce the functional fabric as a substrate.

As shown in the figure, it is possible to figure out the clear difference between the two samples. On the other hand, the result indicates that the functional finishing drawing an alteration in the mechanical properties of the fabric which indirectly approves the change in the tactile comfort of the sample. Finishing altered the shear properties to a little extent. For example, we noted that the shearing properties $(G$, $2 \mathrm{HG}$ and 2HG5) of the functional fabrics distributed in varied level. While the other results displayed at least in the equivalent pattern. For shearing properties, before treatment, we observed a shear rigidity of G $\sim 5.49 \mathrm{~g} / \mathrm{cm} \cdot \mathrm{deg}$, shear hysteresis at $0.5^{\circ}$ shear angle of $2 \mathrm{HG} \sim 2.07 \mathrm{~g} / \mathrm{cm}$, and shear hysteresis at $5^{\circ}$ shear angle of $2 \mathrm{HG} 5 \sim 12.6 \mathrm{~g} / \mathrm{cm}$. After treatment with acidic PEDOT-PSS and glycerol using inkjet printing techniques, we noticed a basic change of shear rigidity G to $\sim 3.44 \mathrm{~g} / \mathrm{cm} \cdot \mathrm{deg}$, shear hysteresis at $0.5^{\circ}$ $2 \mathrm{HG}$ to $\sim 2.3 \mathrm{~g} / \mathrm{cm}$, and shear hysteresis at $5^{\circ} 2 \mathrm{HG} 5$ to $\sim 10.97 \mathrm{~g} / \mathrm{cm}$. This might be ascribed to the process parameters (temperature and pressure of the inkjet printing machine) and the process chemicals (water, acidic PEDOT-PSS and glycerol) might change the physical properties of the fabric during functional finishing actions. This is because PEDOTPSS treated fabrics became stiff [25] which is sup-
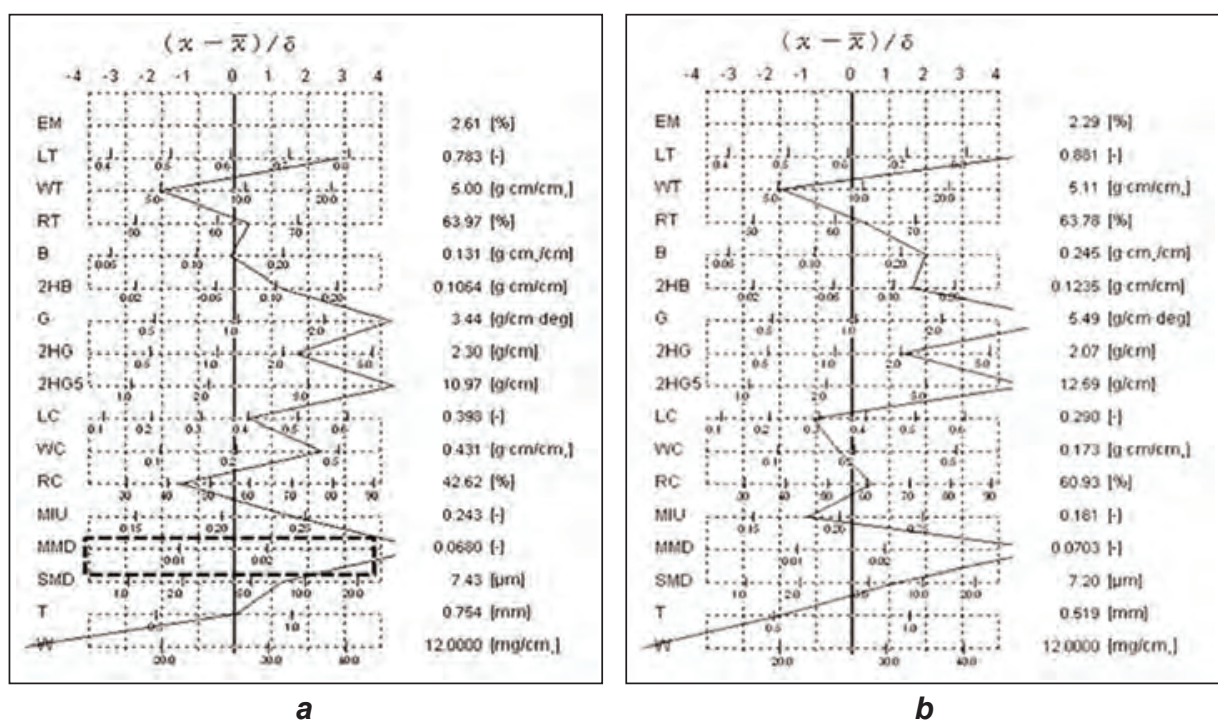

Fig. 2. Quality control chart for primary handle value of: $a$ - functional fabric produced using inkjet printing; $b$ - polyester (control) sample 
ported as the shear rigidity reduced by $\sim 37 \%$. As the shear rigidity increased, the fabric became easily deformed. This means the stiffness is affected due to functional treatment.

In some mechanical results, only slight difference occurred to some level only when compared to other values. For instance, the key feature for the tactile comfort, the finishing effect brought only a few changes in the surface friction properties. The coefficient of friction MIU increased by only $27 \%$. Similarly, the geometrical roughness increased by $3.19 \%$. On the contrary, the mean deviation of the coefficient of friction MMD reduced by $3.27 \%$. MMD is related to the roughness and the smoothness of the surface of the fabric; the larger the MMD value means the rougher the surface is. Here, functional finishing increases the smoothness of the fabric's outer surface. This could be attributed to the functional finishing covers the protruded fibers on the surface of the fabric and hence the roughness decreased.

The overall data chart indicates that the functional finishing bringing about no severe changes in the low-stress mechanical properties and by this, it could be possible to control the quality of the fabric against the standard values. However, some values are falling off the control chart (fall on the non-control zone), then control in the finishing process is required corresponding to the run-in parameters. Otherwise, the zone within the standard deviation zone is a highquality fabric zone, in which the parameters of the high-quality fabrics.

The experimental investigation of the low-stress mechanical properties using KES also used to obtain the primary (Koshi, Numeri and Fukurami for men's winter suit) and the total hand value (THV) of the sample fabrics. Figure 3 demonstrates the primary and THV values. The experiment was performed by assuming both fabrics can be used to produce men's winter suit.

Figure 3 shows the range of primary and total hand values of the functional fabric and its substrate (control) fabric that supposed to be used to produce men's winter suiting fabrics. THV values are regarded as good when it is greater than 4 and poor when it is below 2 out of 5 points. Printing with PEDOT-PSS and glycerol yielded polyester fabrics with total hand values 2.64 (figure 3) which is within the range of medium value while the THV of the control fabric 1.98 is within the range of the poor grade. This could be attributed to the surface physical roughness SMD improved owing to the removal of protruding fibers during finishing. This is because the surface coating was performed using inkjet printing. Both samples showed a preferred KOSHI (stiffness). However, stiffness value reduced during finishing. The other reason could be the gap between the weft and the warp yarn occupied by finishing agents. Thus, the stiffness improved while finished. On the other hand, the NUMERI (smoothness) value is within a very modest value (below zero). This could be ascribed to smoothness subjected to be diminished with the minor

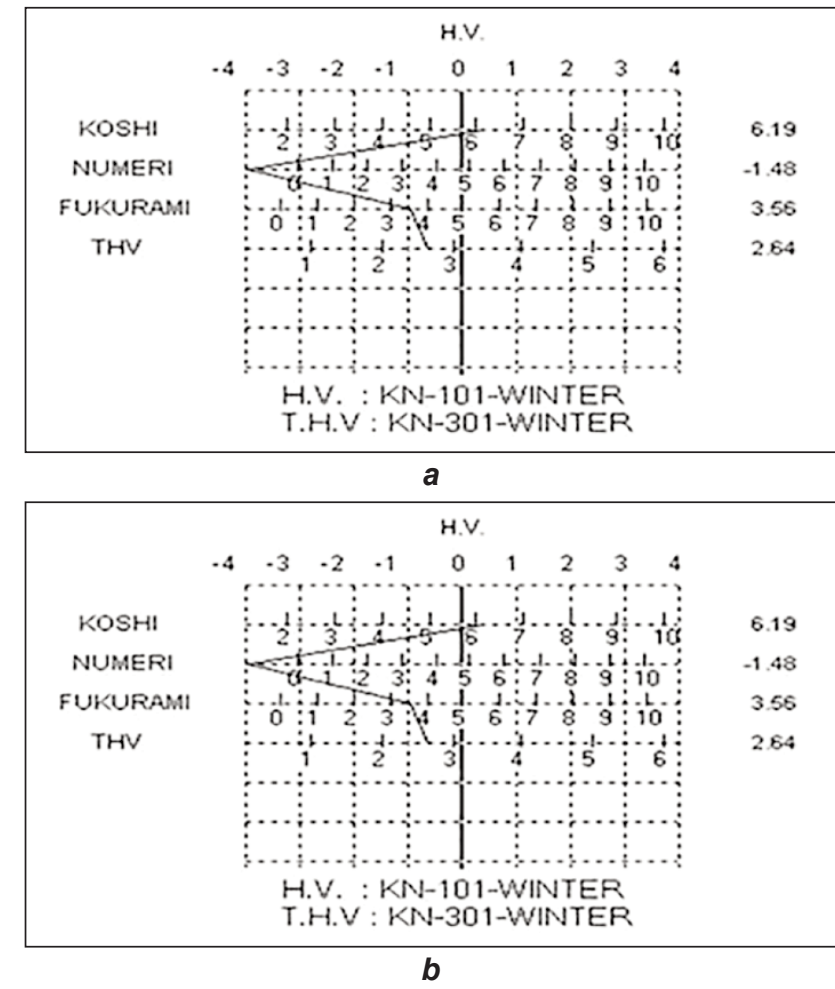

Fig. 3. Experimental values of the primary and total hand values for: $a-$ functional fabric produced using inkjet printing; $b$ - the polyester (control) fabric

variation of the frictional force. But, further investigation is needed in the functional fabric area.

\section{Predicting the primary and total hand values using equation $\mathrm{KN}$-101 series}

After the exhaustive analysis and the interpretation of the low-stress mechanical and surface properties of functional fabrics which goes to tensile, shear, bending, compression, and surface friction were completed; we further proceed to set up the calculation works of primary hand (PHV) and total hand value (THV). This part of the paper utilizes the equations established for conventional fabrics in order to commend or reject the privilege of these types of translation equations for functional fabrics PHV and THV calculations which have been developed by Kawabata for men's winter suit [17]. He defined a primary hand values indicated the elemental fabric hand properties such as stiffness (Koshi), smoothness (Numeri), and fullness (Fukurami) and have the scale range from $0-10$, while the total hand values is an indication of the overall quality index in which a fabric intended for a particular end use and with the scale from 1-5. To achieve this, the population parameters (mean and standard deviations) of the samples were calculated and are presented in table 2. These sixteen lowstress mechanical properties were utilized to compute the primary hand values.

In order to calculate the primary hand values of the functional fabrics, we employed the equations previously developed by Kawabata and his co-workers [17] intended to use for the evaluation of the hand factors for men's winter suiting fabrics $(\mathrm{KN}-101)$ : 


\begin{tabular}{|c|c|c|c|}
\hline \multicolumn{4}{|c|}{$\begin{array}{l}\text { THE SUBSTITUTED POPULATION PARAMETERS } \\
\text { IN EQUATION KN-101 }\end{array}$} \\
\hline \multicolumn{2}{|c|}{ Mechanical parameter } & Mean value & $\begin{array}{c}\text { Standard } \\
\text { deviation } \sigma_{\text {i }}\end{array}$ \\
\hline \multirow{3}{*}{ Tensile } & L T & 0.950 & 0.103 \\
\hline & $\log W T$ & 0.639 & 0.090 \\
\hline & RT & 64.218 & 5.456 \\
\hline \multirow{3}{*}{ Shearing } & $\log G$ & 0.850 & 0.231 \\
\hline & $\log 2 H G$ & 1.008 & 0.370 \\
\hline & $\log 2 \mathrm{HG} 5$ & 1.175 & 0.129 \\
\hline \multirow{2}{*}{ Bending } & $\log B$ & -0.463 & 0.367 \\
\hline & $\log 2 \mathrm{HB}$ & -0.479 & 0.335 \\
\hline \multirow{3}{*}{ Compression } & LC & 0.364 & 0.038 \\
\hline & $\log W C$ & -0.503 & 0.132 \\
\hline & $\mathrm{RC}$ & 48.660 & 5.471 \\
\hline Thickness & $\log T$ & -0.175 & 0.054 \\
\hline Weight & LogW & 1.287 & 0.058 \\
\hline \multirow{3}{*}{$\begin{array}{l}\text { Surface } \\
\text { friction }\end{array}$} & MIU & 0.240 & 0.046 \\
\hline & LogMMD & -1.147 & 0.026 \\
\hline & $\log S M D$ & 0.822 & 0.033 \\
\hline
\end{tabular}

$$
Y_{k}=C_{0}+\sum_{i=1}^{16} C_{i} \frac{X_{i}-\bar{X}}{\sigma_{i}}
$$

where $Y_{k}$ is primary hand values $(k=1,2,3)$ for men's winter suit, 1 - KOSHI, 2 - NUMERI and 3 FUKURAMI, $X_{i}$ - the $i^{\text {th }}$ low-stress mechanical properties or its logarithmic values $(i=1,2,3 \ldots .16)$,

$\mathrm{x}$ and $\sigma_{i}$ are the mean $\&$ the standard deviation of the $i^{\text {th }}$ low-stress mechanical properties and $C_{0}$ and $C_{i}$ are coefficients of constants (for men's winter suit) as developed by Kawabata.

The definitions of the primary hand values are as follows [17]:

- KOSHI (stiffness); a sensation associated with bending stiffness. It is the rigidity of a fabric-the extent to which it resists bending deformation in response to the applied bending force. It is the opposite of being flexible or pliable.

- NUMERI (smoothness); a mixing sensation which derives from smooth, flexible, and soft feeling. Free from projections or unevenness of the surface. It is the direct opposite of roughness.

- FUKURAMI (swelling/softness); it is the extra word for fullness and softness or it is the feeling of being compressible. Or a combined sensation comes from bulky rich and well-formed sensation. Springy property in compression and the thickness accompanied with a warm feeling.

To calculate the primary hand values, we only swapped the mean and the standard deviations of the functional fabrics; the constants used were the

Relationship between the experimental, subjective, and calculated hand factors

After calculating the primary hand and total hand values of the functional fabrics, it is necessary to observe if the translation equations can be implemented to predict the comfort of the functional fabrics. Figure 4 displays the experimental $(E)$ (obtained by KES) and calculated (C) primary hand values of each fabrics using translation equation $\mathrm{KN}-101$. The 


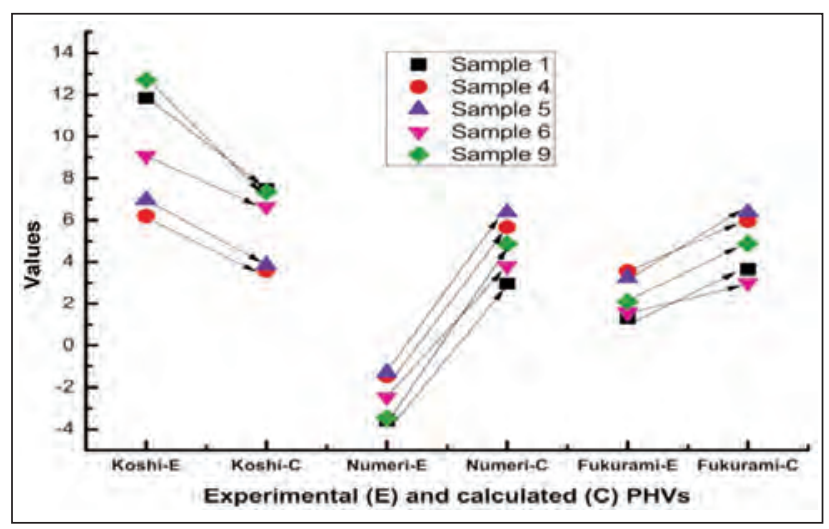

Fig. 4. The experimental $(E)$ and calculated $(C)$ primary hand values of the functional fabrics. The big variation occurred between the experimental and the calculated values of NUMERI

experimental values of NUMERI fall out on the negative axis. Experimental (E) values are the one obtained using KES instrument; calculated $(C)$ values are that obtained when using the Kawabata translation equation (KN-101).

The wearable e-textile samples were intended to be used for producing men's suiting fabrics. For this classification, as noted in the figure, the deviations are in the acceptable range in the sample occurred in terms of their experimental and calculated values of the primary hand values. This was demonstrated by calculating the error values. The error values are $\sim 3.41, \sim 6.60$, and $\sim 2.39$ for Koshi, Numeri, and Fukurami, respectively. These errors are within the standard deviations (SD) of the experiments for which SD of 9.71, 12.25, and 1.94 were observed for Koshi, Numeri, and Fukurami, respectively. However, when samples are treated individually, a difference can be noted between the experimental and calculated values. For instance, sample 1 yielded an experimental Koshi value of 11.84 while the same sample yielded minimum Koshi calculated value of 7.49 which actually means the stiffness value reduced by $\sim 36.7 \%$. On the other hand, for the experimental values, for instance, the Koshi (stiffness) values of sample 9 and 1 were very high with a value of 12.71 and 11.84 , respectively. Also deserve mentioning the lowest (outstanding) value, which is 6.19 for sample 4 . The Fukurami (softness) value of sample 4 was 3.56 while to that of sample 1 was 1.31 . This means sample 1 found to be the least of the other samples in terms of the softness property. The calculated primary hand values of all samples showed the same tendency to that of the experimental values. These experimental and calculated data showed that sample 4 was very qualified with properties having superior flexibility and softness for winter men's apparel suit production when compared to other samples.

For each sample, the correlation coefficients between the calculated and experimental primary hand values were established and the results are illustrated in table 5. The Pearson correlation between the calculated primary hand and the experimental values figuring out that a strong correlation existed between the hand values.

As revealed in the table, except a few results, most correlations are significant at 0.001 confidence level. This result confirmed that Kawabata's translation equation $(\mathrm{KN}-101)$ can be used as genuinely to calculate the primary hand values of the functional fabrics from low-stress mechanical properties. However, the correlation need not necessarily help whether all the data are approximately equal or not. This is because the correlation coefficient only understands the magnitude of the primary hand values. For the reason, it does not take into consideration the negative values of the primary hand when correlation coefficients computed. Therefore, it could be better to

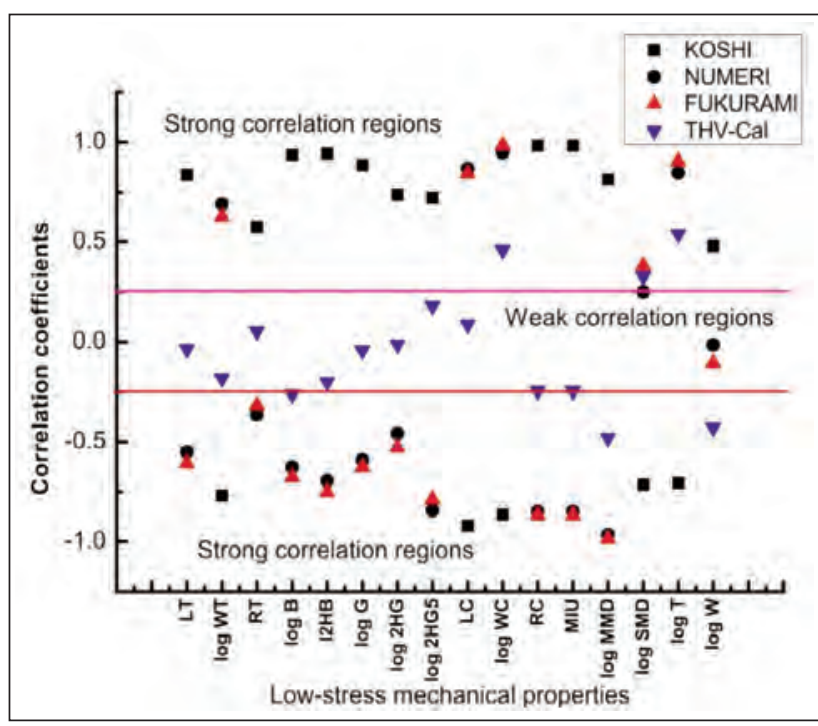

Fig. 5. The correlation coefficients between the low-stress mechanical properties and the calculated primary; total hand values of the functional fabric
Table 5

\begin{tabular}{|c|c|c|c|c|c|}
\hline \multicolumn{6}{|c|}{$\begin{array}{l}\text { THE CORRELATION COEFFICIENTS BETWEEN EXPERIMENTAL AND } \\
\text { CALCULATED PHVS }\end{array}$} \\
\hline PHV & Koshi $_{(E)}$ & Numeri $_{(\mathrm{E})}$ & Fukurami $_{(\mathrm{E})}$ & Koshi $_{(\mathrm{c})}$ & Numeri $_{(\mathrm{c})}$ \\
\hline Numeri $_{(E)}$ & -0.977 & - & - & - & - \\
\hline Fukurami $_{(E)}$ & 0.006 & 0.128 & - & - & - \\
\hline Koshi $_{(\mathrm{c})}$ & 0.943 & -0.963 & -0.254 & - & - \\
\hline Numeri $_{(\mathrm{c})}$ & -0.957 & 0.971 & 0.005 & -0.954 & - \\
\hline Fukurami $_{(\mathrm{c})}$ & -0.703 & 0.805 & 0.621 & -0.888 & 0.777 \\
\hline
\end{tabular}

investigate the meaning of the primary hand values in both axes and take a judge up on it.

In order to further explore the relationship between the calculated hand factors and the mechanical properties measured by Kawabata's evaluation system, the correlation coefficients were calculated and the results are shown in figure 5 . We assumed a correlation coefficient below 0.25 as a 
weak relationship and the result shows that most correlations with THV-Cal are under low regions.

The result is figuring out that, there existed a strong correlation amongst the calculated hand factors and the low-stress mechanical properties up to 0.99. This is an authentic indication of the prediction performances of the translation equations of $\mathrm{KN}$-series for the functional fabric which swayed to be served the same and is in a reliable range. Furthermore, to evaluate the prediction performances of the translation equations to the quality of the functional fabrics, the mean square errors were calculated which could enable to validate its trustworthy. We computed the predictive mean square error (MSE) between the subjective total hand value and the calculated THV using the following equation:

$$
M S E=\frac{1}{n} \sum_{i=1}^{n}\left(Y_{i}-\bar{Y}_{i}\right)^{2}
$$

where $Y_{i}$ is the experimental THV from KES-F \& actual THV given by the panel of experts, $\bar{Y}_{i}$ - the predicted THV using equations $\mathrm{KN}-301$ and $n-$ the number of samples taken.

The equation can help to show whether calculated mean square errors are within the standard deviations of each product which is a variation of the experiment or not. This verifies that $\mathrm{KN}$-equation series developed to evaluate the hand of the men's suiting fabric may possibly be used to predict the tactile comfort of the functional fabrics.

Furthermore, the frequently used measure of the differences between the hand factors predicted by the mechanical parameters and subjective total hand values given by the experts could be better explained by the root mean square error (RMSE):

$$
R M S E=\sqrt{\frac{1}{n}} \sum_{i=1}^{n}\left(Y_{i}-\bar{Y}_{i}\right)^{2}
$$

The tabulated standard deviation of the differences between the predicted and the total hand values of the fabrics is $\sim 0.78$ and the RMSE between the predicted and the rated total hand values found to be $\sim 0.66$. This shows that the root mean square error is within the standard deviation values. This result further confirmed that the prediction performance of the $\mathrm{KN}-301$ equation on the total hand values of the functional fabric using the mechanical parameters obtained by the Kawabata's evaluation system was at an acceptable range and ensured a good agreement to the human perception. While the calculated standard deviation of the differences between the experimental (KES-F) and the predicted THV was found to be $\sim 0.63$ and the RMSE between these two values found to be $\sim 1.32$ which is not within the range of standard deviation (the variation of the experiment). This certified that the experimental THV showed rare discrepancies to that of the predicted value. This intention might be more investigated using large datasets.

To define the relationship between the hand values, we computed the correlation coefficients amongst the
THV measured by the Kawabata's evaluation systems (THV-KES), calculated using Kawabata's translation equation (KES-Cal), and given by the panel of experts (KES-Sub). Table 6 shows the THV obtained using subjective evaluation.

Table 6

\begin{tabular}{|c|c|c|}
\hline \multicolumn{3}{|c|}{ THE TOTAL HAND VALUES AS RATED BY SUBJECTS } \\
\hline Sample Code & THV-Sub & STD \\
\hline 1 & 2.25 & 0.866 \\
\hline 4 & 3.15 & 0.782 \\
\hline 5 & 4.50 & 0.333 \\
\hline 6 & 2.90 & 0.527 \\
\hline 9 & 2.70 & 0.882 \\
\hline
\end{tabular}

Table 7 illustrates the correlation coefficient results between the total hand values obtained using three different mechanisms.

Table 7

RELATIONSHIPS BETWEEN THV-KES, THV-CAL AND THV-SUB

\begin{tabular}{|c|c|c|c|}
\hline THV & THV-KES & THV-Cal & THV-Sub \\
\hline THV-KES & 1 & - & - \\
\hline THV-Cal & -0.016 & 1 & - \\
\hline THV-Sub & 0.727 & 0.339 & 1 \\
\hline
\end{tabular}

The correlation coefficient results declared experimental (THV-KES) and subjectively obtained (THVSub) total hand values attain the highest relationship (at 0.01 confidence level). The calculated and subjectively obtained total hand values are significant at 0.05 confidence level. While the experimental and calculated total hand values showed a weak relationship by attaining a coefficient of correlation $\sim-0.016$. This result confirmed that both subjective evaluation and objective measurement of the mechanical properties can be simultaneously applied to evaluate the comfort of functional fabrics. The subjective total hand value (THV-Sub) has a positive correlation between THV-Cal and THV-KES while it recorded a strong correlation coefficient $(\sim 0.727)$ to that of THV-KES. This result effectively determined that the perception of the human subjects can replace the experimental measurement of the THV using KES. However, the correlation coefficient is not always correct for evaluating the certainty; this is due to the range of the hand values of the samples examined influences remarkably on the correlation coefficients. To support this, the T-test for the two-sample for variance was computed and illustrated in figure 6 .

As showed in figure 6, T-test re-approved the correlation coefficient result. This is because the F-critical one-one-tail value is greater than the $F$-value between THV-Cal and THV-KES while they build a 


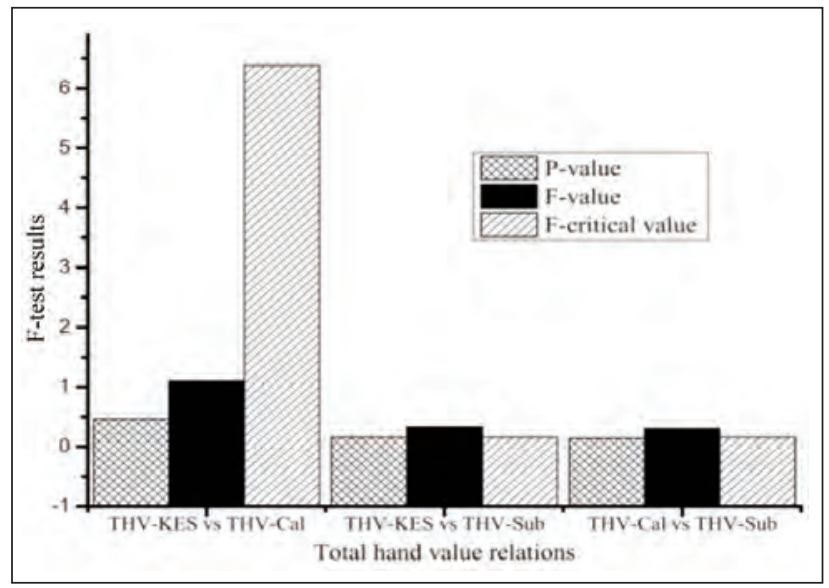

Fig. 6. T-test for two-sample variances for the hand values of experimental calculated and subjectively obtained total hand values of the sample

weak correlation coefficient $(\sim-0.016)$ between them. If the F-critical value is larger than that of the F-value, two samples showed different values in their variance. That means the null hypothesis (two means are equal statistically) will not be considered. The rest, statistically, there showed no big difference.

\section{CONCLUSIONS}

A pre-requisite for the prediction of primary and total hand values of the functional fabric using Kawabata's translation equation is to define the effect of functional finishing using polymers on the fabric's hand. The investigation in this work shows that there exists a change in the mechanical properties of the functional fabrics due to the utilization of different finishing types and parameters. The prediction performance of Kawabata's translations equations to the total hand value was in a satisfactory range as the root mean square error $(\sim 0.66)$ is within the range of the standard deviation $(\sim 0.78)$ of the differences between the calculated total hand value and the total hand value given by human experts. The relationship between the calculated primary hand values to the low-stress mechanical properties of the functional fabric found to be strong and attains up to a correlation coefficient up to $\sim 0.99$. While the relationship between the mechanical properties and the calculated THV found to be medium in which the maximum correlation coefficient was $\sim 0.54$. These results give the evidence that the primary hand values are highly dependent on the mechanical properties while the total hand values might not depend only on the mechanical properties; other factors should be investigated. The calculated and experimental primary hand values attain a correlation coefficient up to $\sim 0.98$ showing that the primary hand values of the functional fabrics can be explained using Kawabata's translation equations.

\section{ACKNOWLEDGEMENTS}

This work was financially supported by Erasmus Mundus Joint Doctorate Programme SMDTex-Sustainable Management and Design for Textile (Grant No. n_20151594/001-001-EMJD). The authors would like to acknowledge The Faculty of Textile Engineering, Technical University of Liberec, Czech Republic, for conducting the Kawabata Evaluation for our samples.

\section{REFERENCES}

[1] Lee, J., Kwon, H., Seo, J., Shin, S., Koo, J.H., Pang, C., Son, S., Kim, J.H., Jang, Y.H., Kim, D.E., Lee, T., Conductive fiber-based ultrasensitive textile pressure sensor for wearable electronics, In: Adv. Mater., 2015, 27, 2433-2439

[2] Zhang, M., Wang, C., Wang, H., Jian, M., Hao, X., Zhang, Y., Carbonized Cotton Fabric for High-Performance Wearable Strain Sensors, In: Adv. Funct. Mater., 2017, 27, 1-7

[3] Cochrane, C., Koncar, V., Lewandowski, M., Dufour, C., Design and development of a flexible strain sensor for textile structures based on a conductive polymer composite, In: Sensors, 2007, 7, 473-492

[4] Seyedin, S., Razal, J.M., Innis, P.C., Jeiranikhameneh, A., Beirne, S., Wallace, G.G., Knitted Strain Sensor Textiles of Highly Conductive All-Polymeric Fibers, In: ACS Appl. Mater. Interfaces, 2015, 7, 21150-21158

[5] Wen, Z., Yeh, M.H., Guo, H., Wang, J., Zi, Y., Xu, W., Deng, J., Zhu, L., Wang, X., Hu, C., Zhu, L., Sun, X., Wang, Z.L., Self-powered textile for Wearable electronics by hybridizing fiber-shaped nanogenerators, solar cells, and supercapacitors, In: Sci. Adv., 2016, 2.e1600097

[6] Tadesse M.G., Loghin, C., Chen, Y., Wang, L., Catalin, D., Nierstrasz, V., Effect of liquid immersion of PEDOT: PSScoated polyester fabric on surface resistance and wettability, In: Smart Mater. Struct., 2017, 26.065016

[7] Tadesse, M.G., Dumitrescu, D., Loghin, C., Chen, Y., Wang, L., Nierstrasz, V., 3D Printing of NinjaFlex Filament onto PEDOT:PSS-Coated Textile Fabrics for Electroluminescence Applications, In:J. Electron. Mater., 2018, 47, 2082-2092

[8] Cardello, A.V, Schutz, H.G., Predicting the Handle and Comfort of Military Clothing Fabrics from Sensory and Instrumental Data: Development and Application of New Psychophysical Methods, In: Text. Res. J., 2003, 73, 221-237

[9] Das, A., Alagirusamy, R., Improving tactile comfort in fabrics and clothing. In Improving Clothing Comfort, Song G. Ed., Woodhead publishing: Oxford,UK, 2011,216-244

[10] Nayak, R.K., Punj, S.K., Chatterjeé, K.N., Behera, B.K., Comfort properties of suiting fabrics, In: Indian J. Fibre Text. Res., 2009, 34, 122-128

[11] Raj, S., Sreenivasan, S., Total Wear Comfort Index as an Objective Parameter for Characterization of Overall Wearability of Cotton Fabrics, In:J. Eng. Fiber. Fabr., 2009, 4, 29-41 
[12] Mahar, T.J., Postle, R., Measuring and Interpreting Low-Stress Fabric Mechanical and Surface Properties: Part IV: Subjective Evaluation of Fabric Handle, In: Text. Res. J., 1989, 59, 721-733

[13] Mahar, T.J., Postle, R., Measuring and Interpreting Low-Stress Fabric Mechanical and Surface Properties: Part II: Applications to Finishing, Drycleaning, and Photodegredation of Wool Fabrics, In: Text. Res. J., 1989, 59,357-368

[14] Mahar, T.J., Wheelwright, P., Dhingra, R.C., Postle, R., Measuring and Interpreting Fabric Low Stress Mechanical and Surface Properties: Part V: Fabric Handle Attributes and Quality Descriptors, In: Text. Res. J., 1990, 60, 7-17

[15] Mahar, T.J., Postle, R., Measuring and Interpreting Low-Stress Fabric Mechanical and Surface Properties:Part III: Optimization of Fabric Properties for Men's. Suiting Materials, In: Text. Res. J., 1989, 59, 448-459

[16] Behera, B.K., Comfort and handle behaviour of linen-blended fabrics, In: Autex Res. J., 2007, 7, 32-47

[17] Kawabata, S., The Standardization and Analysis of Hand Evaluation. In Effect of Mechanical and Physical Properties on Fabric Hand, 2nd ed., M.H. Behery Ed., Woodhead Publishing: Cambridge, England, 2005, 389-442

[18] Mitsu, M., Masahiko, K., Objective Evaluation of Hand for Futon Cloth, In: J. Text. Mach. Soc. Japan., 1996, 42, 23-35

[19] Singh, J.P., Behera, B.K., Matsudaira, M., Objective evaluation of terry fabric hand, In: J. Text. Inst., 2014,105, 467-476

[20] Niwa, M., Inoue, M., Kawabata, S., Objective evaluation of the handle of blankets, In: Text. Res. J., 2001, 71, 701-710

[21] Kawabata, S., Niwa, M., Wang, F., Objective Hand Measurement of Nonwoven Fabrics: Part I : Development of the Equations, In: Text. Res. J., 1994, 64, 597-610

[22] Yokura, H., Kohono, S., Iwasaki, M., Objective hand measurment of toilet paper, In: J. Text. Eng., 2004, 50, 1-5

[23] Seipel, S., Yu, J., Periyasamy, A.P., Viková, M., Vik, M., Nierstrasz, V.A., Inkjet printing and UV-LED curing of photochromic dyes for functional and smart textile applications, In: RSC Adv., 2018, 8, 28395-28404

[24] Tadesse, M.G., Harpa, R., Chen, Y., Wang, L., Nierstrasz, V., Loghin, C., Assessing the comfort of functional fabrics for smart clothing using subjective evaluation, In: J. Ind. Text., 2018, doi:10.117/152808371874906.

[25] Ryan, J.D., Mengistie, D.A., Gabrielsson, R., Lund, A., Müller, C., Machine-Washable PEDOT:PSS Dyed Silk Yarns for Electronic Textiles, In: ACS Appl. Mater. Interfaces., 2017, 9, 9045-9050

Author:

MELKIE G.TADESSE ${ }^{1}$, EMIL-CONSTANTIN LOGHIN², VINCENT NIERSTRASZ³ ${ }^{3}$ MARIA-CARMEN LOGHIN²

${ }^{1}$ Bahir Dar University, Ethiopian Institutes of Textile and Fashion Technology, 608 Bahir Dar, Ethiopia

${ }^{2}$ Gheorghe Asachi Technical University of lasi, Faculty of Industrial Design and Business Management, Knitting and Clothing Engineering Department, Bld. D. Mangeron no. 29, 700050, lași, Romania

3University of Boras, Swedish School of Textiles, Department of Materials Technology, 50190, Boras, Sweden

Corresponding author:

LOGHIN EMIL-CONSTANTIN

e-mail: eloghin@tuiasi.ro 


\title{
Dyeing and colour fastness of natural dye from Citrus aurantium on Lyocell fabric
}

\author{
DOI: $10.35530 / I T .071 .04 .1686$
}

NAVEED TAYYAB

RASHDI YASEEN SAYED

AWAN ASHRAF JAVEED

ABBAS MUDASSAR

REHMAN FAISAL

FRAZ AHMAD

WEI WANG

AWAIS MUHAMMAD

\section{ABSTRACT - REZUMAT}

Dyeing and colour fastness of natural dye from Citrus aurantium on Lyocell fabric

The use of natural dyes for textiles has attained attention due to their ecology, minimum impact on the environment and pollution. Therefore the objective of this study is to dye Lyocell fabric with natural dye extracted from orange peel for comparative analysis of colour efficiencies (K/S), CIE $L^{*} a^{*} b^{*}$ values and the colour fastness properties. The mordants applied were ferrous (II) sulphate and copper (II) sulphate. For the extraction of the dye, the aqueous extraction method was used. The pre-mordanting method was used and the dyeing effect on Lyocell fabric was analyzed at concentrations of $2 \%$ and $4 \%$. It was observed that the mordant type employed had an influence on the colour efficiency and the colour coordinates of fabric dyed with Citrus aurantium dye. The colour efficiency (K/S: 4) and colour fastness to washing, light, rubbing and perspiration in all the dyed samples were better and excellent (grade 4-5) at 4\% concentration. In overall results, the pre-mordanting method at $4 \%$ concentration gives the best results of colour efficiency and colour fastness properties. The performance analysis of colour fastness was also statistically significant at the 0.05 level.

Keywords: natural dyes, orange peel, Lyocell, extraction, mordant, colour fastness

\section{Vopsirea și rezistența culorii colorantului natural din Citrus aurantium pe țesătura din Lyocell}

Utilizarea coloranților naturali pentru materialele textile a atras atenția datorită aspectelor legate de ecologie, impactul minim asupra mediului și poluare. Prin urmare, obiectivul acestui studiu este vopsirea țesăturii din Lyocell cu colorant natural extras din coaja de portocală, pentru analiza comparativă a eficienței culorilor (K/S), valorile CIE $L^{*} a^{*} b^{*}$ și proprietățile de rezistență a culorii. Mordanții aplicați au fost sulfat feros (II) și sulfat de cupru (II). Pentru extragerea colorantului s-a utilizat metoda de extracție apoasă. S-a utilizat metoda cu pre-mordant și s-a analizat vopsirea pe țesătura din Lyocell la concentrații de $2 \%$ și $4 \%$. S-a observat că tipul de mordant folosit a influențat eficiența culorilor și coordonatele de culoare ale țesăturii vopsite cu colorant Citrus aurantium. Eficiența culorii (K/S: 4) și rezistența culorii la spălare, lumină, frecare și transpirație la toate probele vopsite au fost mai bune și excelente (grad 4-5) la o concentrație de $4 \%$. In ceea ce privește rezultatele generale, metoda de pre-mordansare la o concentrație de $4 \%$ oferă cele mai bune rezultate ale eficienței culorii și proprietății de rezistență a culorii. Analiza performanței rezistenței culorii a fost, de asemenea, semnificativă statistic la nivelul 0,05.

Cuinte-cheie: coloranți naturali, coajă de portocală, Lyocell, extracție, mordant, rezistența culorii

\section{INTRODUCTION}

Since 1856, the use of synthetic dyes has opened gigantic benefits to apply solid colours to the textile fibers and fabrics due to their lightweight, ease of processing, quite lower costs and moderate-to-excellent colour fastness properties [1]. However, their discarding process and petroleum-based starting materials have created severe hazardous to our environment due to their non-biodegradable nature [2]. Consequently, many nations have restricted various particular azo-dyes $(-\mathrm{N}=\mathrm{N}-)$ for their applications and manufacturing [3]. In that regard, the replacement of conventional synthetic dyes with natural dyes is an attractive option to mitigate the problems of pollution and hazardous waste [4].
Natural dyes hold great promise of sustainability, offering the potential of being renewable, biodegradable and anti-allergic from harmful additives [5-6]. Moreover, they have a massive worth in the perspective of deteriorating conventional synthetic polymers and global warming associated with it [7]. Thus minimizing environmental impact, the natural dyes have been used for the colouring of textiles materials since Bronze Age [8]. However, in this modern era, their applications and comprehensive usage have been developed towards the antimicrobial finishing of textiles, UV protective clothing, food colorations, cosmetics, and pharmaceuticals etc. [9]. Moreover, the interest and demand in natural dyes are continuously increasing for the reason that it does not implicate any strong acerbic and alkalis in their uses and fabrications [10]. 
The dyes which are derived from natural sources like plants, minerals, and animals are known to be natural dyes [11]. They are colorants that are attained without applying any chemicals. However, the pure dye content and colour yield in dye plant is very low, relative to synthetic dye [12]. In plants, colouring agents are acquired from, leaves, fruits, flowers, roots and barks [13]. Some of the imperative natural dyes are orange, pomegranate, eucalyptus, Kamala, madder, henna, turmeric etc. [14]. Natural dyes have several technical limitations of colour fastness like colour yield, reproducibility results, difficulties of dying procedure and mixing problems [15]. Moreover, natural dyes have poor fastness properties since they have a very low affinity for fibers and fabrics [16]. Therefore mordants are applied with natural dyes to make their affinity with textile fibers during the production [17].

Mordants play a very important role in giving colour to the textile fabric. A mordant is an element which not only causes a chemical reaction but also makes a bridge between the dye and the fabric [18]. It also increases the dye uptake properties between the dye and fibers [19]. It gives different shades when applied in different percentages. Hence it delivers an extensive variability of colour shades with suitable intensities of colour fastness [20]. Sahoo et al. reported the colour shade strength influenced by the concentration of the metal salts used [21]. It also equally depends upon the rise in temperature [22]. The most widely used mordants are ferrous sulphate, copper sulphate, chrome, alum, and stannous chloride etc. [23]. The metal ions of mordants form co-ordinate and covalent bond with the dye molecule. The metal ions accept an electron from the dye molecule which is insoluble in water and thus easily drained out [24]. Subsequently, the size of the dye molecules increased and the light fastness properties improved.

Lyocell is a regenerated cellulosic fiber. It is prepared from wood pulp and is an excellent ecological fabric that specifies a milestone in the progress of environmental sustainable textile [25]. Orange is one of the most common and famous fruit in the world which yearly yield over 100 million tons [26]. Moreover, orange peel (OP) i.e. shell of the orange fruit is the bio-resource wastage and is present in abundance [27]. The bright orange colour extracted from OP generally originates from phenolic compounds [28]. Additionally, it has antimicrobial and UV-protection properties and for that reason could be used as a natural dye or textile finishes [29]. In the literature, many research studies have been done with the dye extracted from orange peel for dyeing textile materials, such as wool and cotton etc. [30-32]. Edeen reported the higher performance mechanical properties of cotton fabric while treated with orange peel extract [31]. Similarly, Kumar and Karan also proved higher performance characteristics of cotton fabric with orange peel and lemon peel extract [33]. Xiuliang Hou et al. achieved remarkable colour fastness and UV-protection properties in the wool fabric samples dyed with orange peel extract [34]. Formerly no investigation has been described on dyeing Tencel fabric with natural dye extracted from orange peel. Therefore the authors have examined the dyeing and colour fastness of natural dye from orange peel on Lyocell fabric.

In the present study, the chemical composition of OP waste has been determined through physiochemical analysis for pectinase production. The analysed OP waste contained moisture $(40.7 \%)$, ash $(7.39 \%)$, fat $(1.85 \%)$, pectin $(7.0 \%)$, lignin $(6.4 \%)$, crude fiber $(7.8 \%)$, total sugar $(14.08 \%)$, reducing sugars $(10.70 \%)$ and non-reducing sugar $(3.70 \%)$. The Lyocell fabric is dyed with natural dyes extracted from orange peel. Moreover, two mordants (ferrous sulphate and copper sulphate) have also been applied to evaluate the excellence of their application with the Lyocell fabric.

\section{MATERIALS AND METHODS}

\section{Materials}

Dye plant: Orange fruits (Tangerine) were purchased from the local market of Songjiang in Shanghai, China.

Fabric: 100\% Lyocell fabric was used for dyeing, which was obtained from Hangzhou Xinsheng Printing and Dyeing Company LTD (Xiaoshan Hangzhou).

Chemicals: Laboratory grade metallic salts such as ferrous (II) sulphate, (FeSO4.7H2O manufactured by Sinopharm Chemical Reagent, CO.LTD) and (copper (II) sulphate, CuSO4.5H2O manufactured by Sinopharm Chemical Reagent, CO.LTD) were applied as a chemical mordant.

Raw material preparation: Peels were removed from the oranges and washed with water for the removal of the dust particles or other impurities. The washed peels were dried in the oven for 20 hours at a temperature of $30^{\circ} \mathrm{C}$. Subsequently, the dried peels were ground into powder form (for the extraction process) through the grinder machine. Figure 1 has delineated the preparation of raw material.

Equipment: Weighing balance (having accuracy of $0.01 \mathrm{~g}$ ), Water bath, Soxhlet extractor, Water Shaker, Hot air oven, Data colour.

\section{Methods}

Extraction of natural dyes: Aqueous extraction method (Soxhlet apparatus) [6] was used for the extraction of dye from orange peels (OP). $10 \mathrm{~g}$ powder of OP was taken in the round bottom flask with the addition of $200 \mathrm{ml}$ distilled water. Moreover 1:20 material to liquor ratio (M.L.R) was retained. The flask was heated at $90^{\circ} \mathrm{C}$ temperature for 1 hour in the water bath. The vapours passed through the channel and rose up over the top into the condenser. In the thimble, the condensed vapours dropped and thus the extracted material transferred back into the flask and started mixing with the solvent. The thimble was exhausted and continued working for $100 \mathrm{~min}$. After the dye extraction, the solution was filtered 


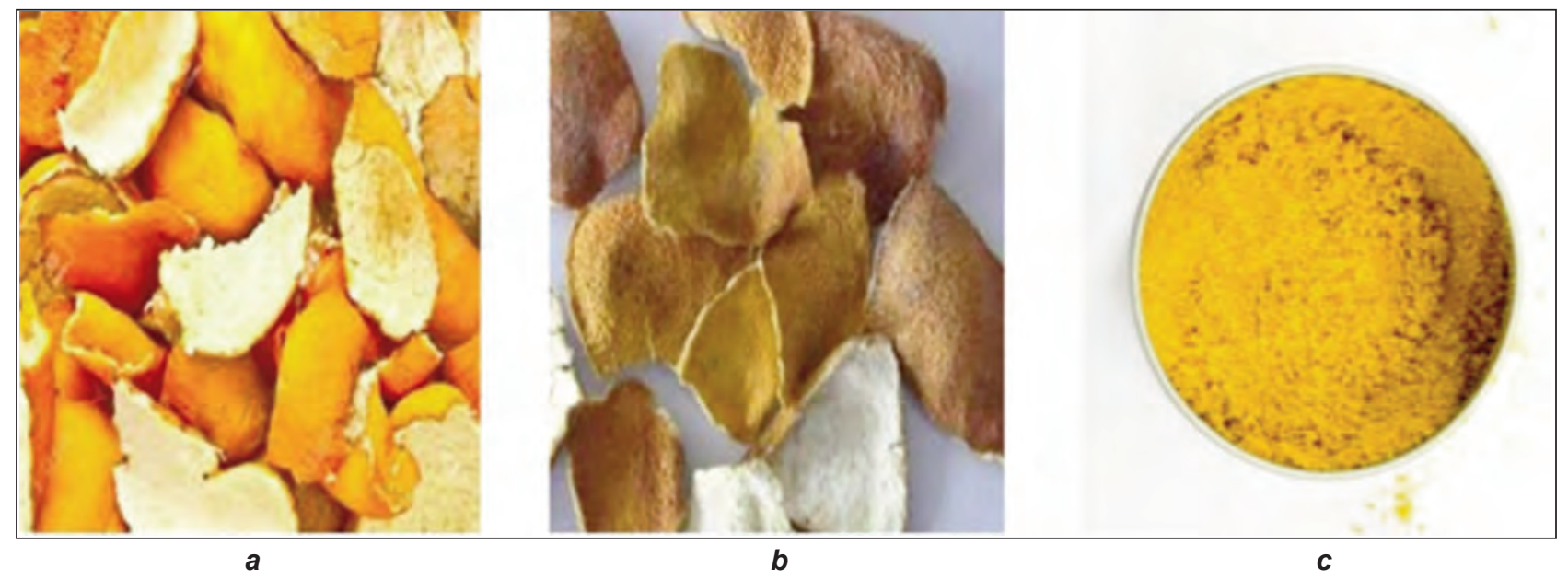

Fig. 1. Preparation of orange peel raw material: $a$ - washed orange peel; $b$-dried orange peel; $c$ - orange peel powder

through Whatman filter paper. It was further purified through a rotary evaporator and was used for the dyeing process.

Mordanting: Lyocell fabric samples were treated separately with two mordants, ferrous sulphate and copper sulphate, for 1 hour at temperature $80^{\circ} \mathrm{C}$. Premordanting technique was applied with liquor ratio $1: 20$. After finishing the mordanting, the Lyocell fabric samples were washed and dried at $26^{\circ} \mathrm{C}$ temperature and further used for the dyeing process.

Dyeing: Lyocell fabric samples were dyed through the exhaust method (Jigger Dyeing machine). The samples were also dyed at different concentrations ( $2 \%$ and $4 \%$ ) in order to compare the effectiveness of the colour results of the fabric samples. The mordants were applied prior to the solution to increasing the dyeability of the Lyocell fabric samples since textile materials have a poor affinity for the dyes. The fabric samples were immersed in the dye solution and dyed for 1 hour with material to liquor ratio (M.L.R; 1:40). The temperature was maintained at $80^{\circ} \mathrm{C}$ for proper diffusion and penetration of dye in the fabric samples. The dye ability of the fabric samples increases with the increase in concentration of the mordants since the dye molecules make strong coordination bonding. Subsequently, the dyed fabric samples were washed with water and soaping agents, and then applied for testing after drying.
Characterization: The dyed fabric samples were examined for different colour fastness properties according to ISO standards like colour fastness to light (ISO 105-B02), washing (ISO 105-C01), rubbing (dry and wet) (ISO 105-X12) and perspiration (ISO 105-E04). Furthermore, the K/S value was used to measure the colour shade strength and dye absorption of the dyed sample.

\section{RESULTS AND DISCUSSIONS}

Orange peel was used for dyeing Lyocell fabric with two types of mordants i.e. ferrous sulfate and copper sulfate, at two different concentrations ( $2 \%$ and $4 \%$ ). With the similarly extracted dye, different shade colors were attained by changing mordants. Different fastness properties were assessed. Moreover, the pre-mordanting method was applied as a mordanting process.

\section{Color measurement and dye absorption}

The dye absorption and color shade of dyed fabric samples were evaluated through K/S values. The dye absorption concentration was measured with the data color SF-600. A number of different color ranges were found on Lyocell fabric samples by using $L^{*}, a^{*}$, $b^{*}, C^{*}, h^{*}$. Table 1 has shown the raw material and different shades of dyeing on the Lyocell fabric samples with ferrous sulfate and copper sulfate at two different concentrations ( $2 \%$ and $4 \%$ ).

\begin{tabular}{|c|c|c|c|}
\hline \multicolumn{4}{|c|}{ EFFECT OF TWO MORDANTS ON LYOCELL FABRIC SAMPLES } \\
\hline Mordants & Raw material & $\mathbf{2 \%}$ concentration & $\mathbf{4 \%}$ concentration \\
\hline $\mathrm{FeSO}_{4}$ & & & \\
\hline $\mathrm{CuSO}_{4}$ & & & \\
\hline
\end{tabular}




\begin{tabular}{|c|c|c|c|c|c|c|c|}
\hline \multicolumn{8}{|c|}{ CIE $L^{*}, a^{*}, b^{*}, C^{*}, h^{*}$ AND K/S VALUES OF DYED LYOCELL FABRIC } \\
\hline Mordant & Concentration (\%) & $\mathrm{K} / \mathrm{S}$ & $\mathbf{L}^{*}$ & $a^{*}$ & $\mathbf{b}^{*}$ & $C^{*}$ & $\mathbf{h}^{*}$ \\
\hline \multirow{2}{*}{$\mathrm{FeSO}_{4}$} & 2 & 2.81 & 54.86 & 2.18 & 3.61 & 4.02 & 82.97 \\
\hline & 4 & 4.0 & 44.93 & 0.31 & 1.25 & 1.28 & 75.85 \\
\hline \multirow{2}{*}{$\mathrm{CuSO}_{4}$} & 2 & 2.06 & 80.05 & 4.67 & 25.71 & 26.13 & 79.72 \\
\hline & 4 & 2.93 & 76.05 & 4.33 & 24.94 & 25.31 & 80.15 \\
\hline
\end{tabular}

Table 2 has shown the overall color shade and $L^{*}, a^{*}$, $b^{*}, C^{*}$ and $h^{*}$ values. It has indicated that lower value of $L^{*}$ has darker shades and higher value of $L^{*}$ has lighter shade for Lyocell and likewise negative values of $a^{*}$ and $b^{*}$ denoted green and blue. Furthermore, the highest color value $(\mathrm{K} / \mathrm{S}=4)$ was obtained with ferrous sulfate and lowest color value $(K / S=2.06)$ with copper sulfate. The experimental outcomes indicated that the OP dye using ferrous sulfate with concentration $4 \%$ has promising results on Lyocell fabric. Figure 2 shows the K/S values of Lyocell fabric with mordant (ferrous sulfate and copper sulfate) at concentration $2 \%$ and $4 \%$. Figure 2 depicts that the $\mathrm{K} / \mathrm{S}$ values of dyed Lyocell with mordant ferrous sulfate has higher values at both concentrations than copper sulfate. Colored bars in the figure have represented

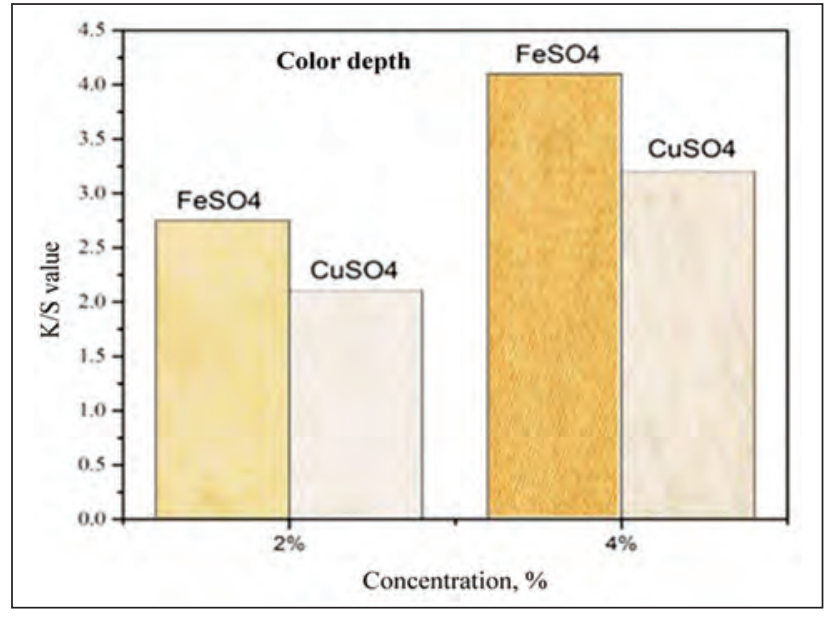

a

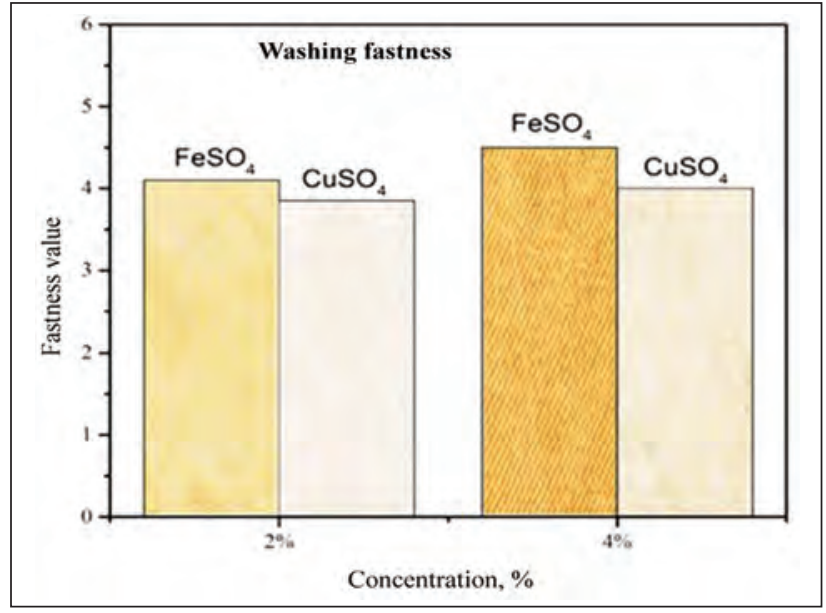

C the outcomes of shade difference at both concentrations with the utilization of both mordants. The highest $\mathrm{K} / \mathrm{S}$ value i.e. 4 was achieved at concentration $4 \%$ with ferrous sulfate and lowest K/S value (2.06) with copper sulfate at concentration $2 \%$.

\section{Color fastness properties of dyed Lyocell}

Extracted dye from orange peel has contributed good washing, light, rubbing and perspiration fastness properties with ferrous sulfate and copper sulfate on Lyocell fabric.

Light fastness: figure 2, a has revealed the result of the lightfastness of Lyocell fabric with orange peel dyed with mordant ferrous sulfate and copper sulfate. It has been observed that ferrous sulfate showed good lightfastness results than the copper sulfate.

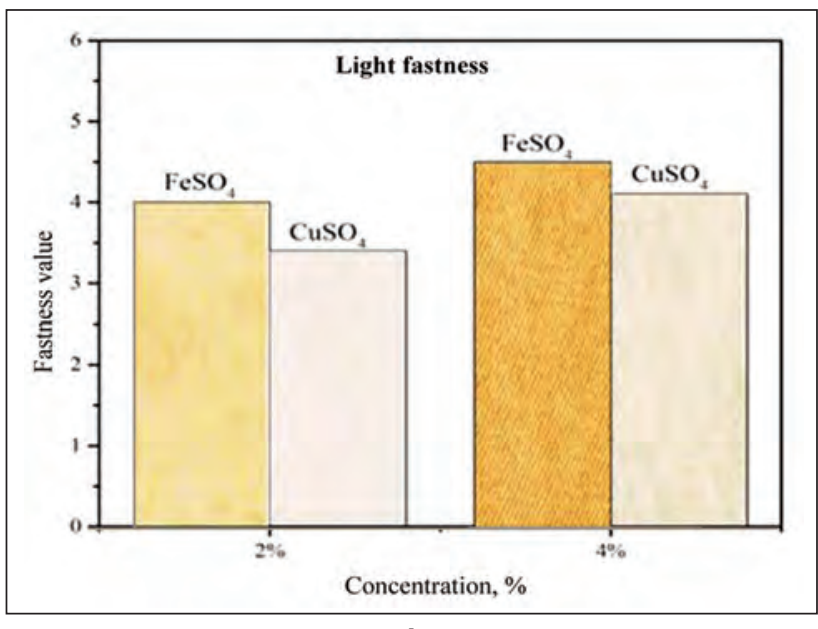

b

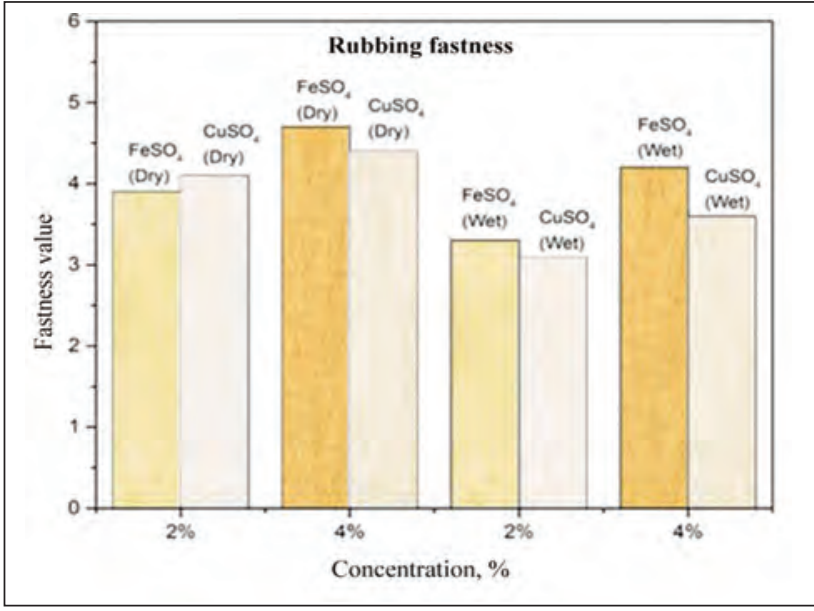

d

Fig. 2. Colour fastness values of dyed Lyocell: $a$ - colour depth; $b$ - light fastness; $c$ - washing fastness; $d$ - rubbing fastness 


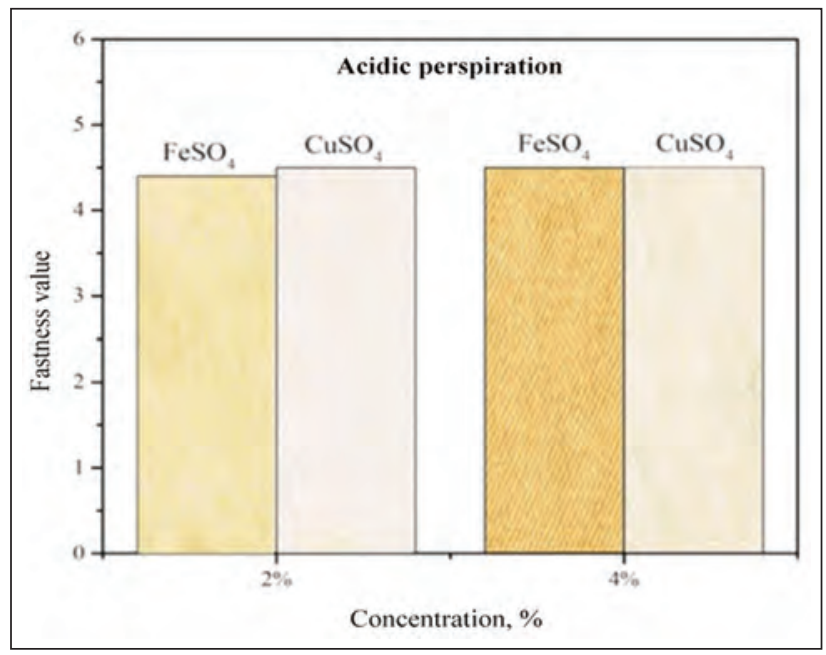

a

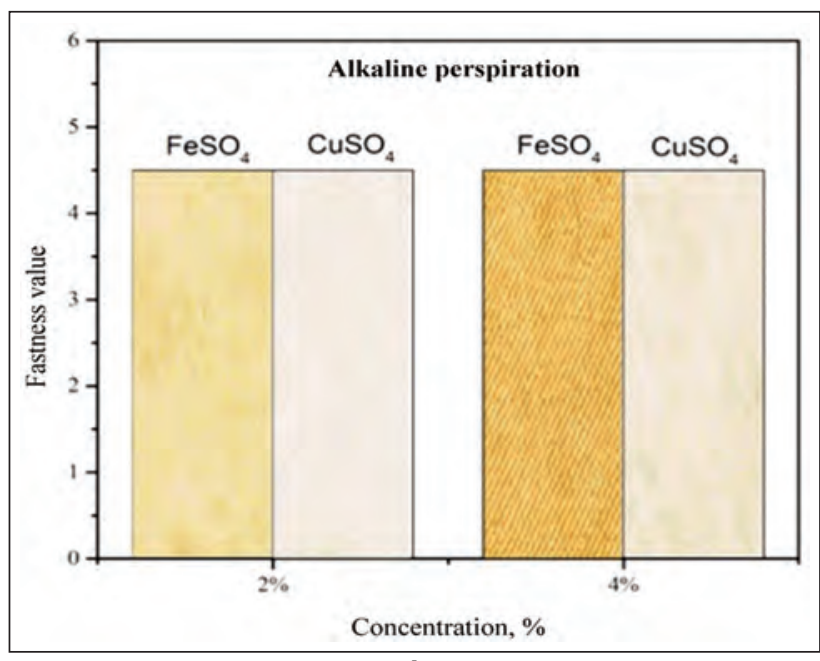

b

Fig. 3. Perspiration fastness result of dyed Lyocell: $a$ - acidic perspiration; $b$ - alkaline perspiration

Through ferrous sulfate, there was no change in color and no color fading. In figure $2, b$ it is evident that dyeing with mordant ferrous sulfate at concentration $4 \%$ has the highest lightfastness (4-5) whereas through copper sulfate light fastness is the lowest (3-5) at concentration $2 \%$. Consequences demonstrated that mordant ferrous sulfate at concentration $4 \%$ is suitable to dye Lyocell fabric.

Washing fastness: figure 2, $c$ has demonstrated the washing fastness effect of dyed Lyocell fabric. The mordant ferrous sulfate has the highest value of washing fastness at both concentrations than copper sulfate. However, at concentration $4 \%$, the results are better (4-5). While with mordant copper sulfate the results are lowest with value (3-4) particularly at concentration $2 \%$. All the samples have a slight change in color (4-5). Figure 2, $c$ also revealed that chemical ferrous sulfate is much better than copper sulfate.

Rubbing fastness (dry and wet): Figure 2, $d$ has presented the rubbing fastness results of Lyocell fabric dyed with extracted dye from orange peel at concentration $2 \%$ and $4 \%$. The light orange and light grey color bars have represented treatment at $2 \%$ while dark orange and dark grey bar colors have displayed the performance at $4 \%$. The mordant ferrous sulfate shows very good to excellent (4-5) dry rubbing and (4) wet rubbing at $4 \%$. Mordant copper sulfate has shown very well (4) dry and wet rubbing fastness at both $2 \%$ and $4 \%$ concentrations. Furthermore, the result depicts that, dry rubbing is better than wet rubbing. Ferrous sulfate showed promising results as compared to copper sulfate at concentration $4 \%$.

Perspiration fastness: Figure $3, a$ and $b$ shows the result of perspiration fastness (acidic and alkali) of Lyocell fabric dyed with orange peel. It was observed that fabric samples treated with ferrous sulfate and copper sulfate exhibit good perspiration fastness at both concentrations i.e. $2 \%$ and $4 \%$. In acidic and alkaline perspiration tests, the fabrics have slight color change (4/5). The staining has also been noticed very light with both chemicals at both concentrations. Table 3 has shown the overall result of colorfastness to washing, light, rubbing (dry and wet) and perspiration fastness of Lyocell fabric dyed with extracted dye from the orange peel with ferrous sulfate and copper sulfate at concentration $2 \%$ and $4 \%$. The performance analysis of colorfastness was also statistically analyzed using t-test (investigate whether the means of two groups or samples are statistically different from each other). Table 4 has shown colorfastness results in $\mathrm{FeSO}_{4}$ and $\mathrm{CuSO}_{4}$ mordants. It was observed a statistically significant difference ( $p$-value $=0.025$ ) in treatments of both mordants at the level of 0.05 . $\mathrm{FeSO}_{4}$ has better results for washing fastness, light fastness, rubbing fastness and perspiration fastness as compared to $\mathrm{CuSO}_{4}$ since ferrous sulfate (green color solution) is a reducing agent and

\begin{tabular}{|c|c|c|c|c|c|c|c|}
\hline \multicolumn{8}{|c|}{ COLOR FASTNESS PROPERTIES OF LYOCELL FABRIC DYED WITH ORANGE PEEL } \\
\hline \multirow{2}{*}{ Mordant } & \multirow{2}{*}{$\begin{array}{c}\text { Concentration } \\
(\%)\end{array}$} & \multirow{2}{*}{$\begin{array}{c}\text { Washing } \\
\text { fastness } \\
\text { ISO 150-C01 }\end{array}$} & \multirow{2}{*}{$\begin{array}{c}\text { Light } \\
\text { fastness } \\
\text { ISO 105-BO2 }\end{array}$} & \multicolumn{2}{|c|}{$\begin{array}{l}\text { Rubbing fastness } \\
\text { ISO 105-X12 }\end{array}$} & \multicolumn{2}{|c|}{$\begin{array}{l}\text { Perspiration fastness } \\
\text { ISO 105-E04 }\end{array}$} \\
\hline & & & & Dry & Wet & Acidic & Alkali \\
\hline \multirow{2}{*}{$\mathrm{FeSO}_{4}$} & 2 & 4 & 4 & 4 & $3-4$ & $4-5$ & $4-5$ \\
\hline & 4 & $4-5$ & $4-5$ & $4-5$ & 4 & $4-5$ & $4-5$ \\
\hline \multirow{2}{*}{$\mathrm{CuSO}_{4}$} & 2 & $3-4$ & $3-4$ & 4 & 3 & $4-5$ & $4-5$ \\
\hline & 4 & 4 & 4 & 4 & $3-4$ & $4-5$ & $4-5$ \\
\hline
\end{tabular}


STATISTICAL T-TEST FOR COLORFASTNESS

\begin{tabular}{|c|c|c|c|c|c|c|}
\hline Mordant & N & Mean & St Dev & $\begin{array}{c}\text { SE } \\
\text { Mean }\end{array}$ & $\begin{array}{c}\text { T- } \\
\text { Value }\end{array}$ & $\begin{array}{c}\text { P- } \\
\text { Value }\end{array}$ \\
\hline $\mathrm{FeSO}_{4}$ & 6 & 4.417 & 0.204 & 0.083 & \multirow{2}{*}{3.16} & 0.025 \\
\hline $\mathrm{CuSO}_{4}$ & 6 & 4.083 & 0.376 & 0.154 & & \\
\hline
\end{tabular}

has lower solubility while copper sulfate (blue color solution) is a weak oxidizing agent and has higher solubility.

\section{CONCLUSIONS}

In the present study, Lyocell fabric was dyed with orange peel. The aqueous extraction method was used to extract dye from orange peel. Two mordants, ferrous sulphate, and copper sulphate were used to analyse the colour strength and washing, light and rubbing fastness properties of Lyocell fabric. The pre-mordanting method was used with $2 \%$ and $4 \%$ concentrations to evaluate the effect of colour shades. Both mordants showed good results on Lyocell fabric. However ferrous sulphate was better than copper sulphate. The overall result revealed that ferrous sulphate is a better choice for Lyocell fabric dyeing at concentration $4 \%$ since it has a good colour efficiency (K/S: 4) and colour fastness to washing (4-5), light (5), rubbing (4-5) and perspiration (4-5). The performance analysis of colour fastness was also statistically significant at the 0.05 level. Also, the Lyocell fabric dyed with natural citrus aurantium can be a breakthrough to environmental safety and human health fortification.

\section{ACKNOWLEDGEMENT}

The research was supported by the Fundamental Research Funds for the Central Universities (No.17D310503) and National Natural Science Foundation of China (No.51403032).

\section{REFERENCES}

[1] Rehman, F., Sanbhal, N., Naveed, T., Farooq, A., Wang, Y., Wei, W., Antibacterial performance of Tencel fabric dyed with pomegranate peel extracted via ultrasonic method, In: Cellulose Journal, 2018, 25, 4251-4260

[2] Adeel, S., Ali, S, Bhatti, I.A., Zsila, F., Dyeing of cotton fabric using pomegranate (Punica granatum) aqueous extract, In: Asian Journal of Chemistry, 2009, 21, 5, 3493-3499

[3] Patel, N., Natural dye based sindoor, In: Life Sciences Leaflets, 2011, 11, 355-361

[4] Kulkarni, S., Bodake, U., Pathade, G., Extraction of Natural Dye from Chili (Capsicum Annum) for Textile Coloration, In: Universal Journal of Environmental Research \& Technology, 2011, 1, 1, 58-63

[5] Shahid, M., Mohammad., F, Perspectives for natural product based agents derived from industrial plants in textile applications - a review, In: Journal of cleaner production, 2013,57, 2-18

[6] Rehman, F., Naveed, T., Yousafzai, W., Wei, W., Study on Tencel Fabric Dyeing with Pomegranate Peel Natural Dyes, In: Asian Journal of Chemistry, 2017, 29, 10, 2279-2284

[7] Jung, J.S., Natural Dyeing of Cotton and Silk with Red Pigment Extract from Safflower, In: International Journal of u-and e-Service, Science and Technology, 2016, 9, 8, 161-168

[8] Davulcu, A., Benli, H., Sen, Y., Bahtiyari, M.I., Dyeing of cotton with thyme and pomegranate peel, In: Cellulose, 2014, 21, 6, 4671-4680

[9] Lokesh, P., Swamy, M., Extraction of natural dyes from Spathodea campanulata and its application on silk fabrics and cotton, In: Der ChemicaSinica, 2013, 4, 1, 111-115

[10] Mahanta, D., Tiwari, S., Natural dye-yielding plants and indigenous knowledge on dye preparation in Arunachal Pradesh, northeast India, In: Current science, 2005, 1474-1480

[11] Sachan, K., Kapoor., V., Optimization of extraction and dyeing conditions for traditional turmeric dye, In: Indian Journal of traditional knowledge, 2007, 6, 2, 270-278

[12] Siva, R., Status of natural dyes and dye-yielding plants in India, In: Current Science, 2007, 92, 7

[13] Farooq, A., Ali, S., Abbas, N., Zahoor, N., Ashraf, M.A., Optimization of extraction and dyeing parameters for natural dyeing of cotton fabric using Marigold (Tagetes erecta), In: Asian Journal of Chemistry, 2013, 25, 11, 5955-5959

[14] Pruthi, N., Chawla, G.D., Yadav, S., Dyeing of silk with barberry bark dye using mordant combination, In: Natural Product Radiance, 2008, 7, 1, 40-44

[15] Win, Z.M., Swe, M.M., Purification of the natural dyestuff extracted from Mango bark for the application on protein fibers, In: World Acad Sci Eng Technol, 2008, 22, 536-540

[16] Samanta, A.K., Agarwal, P., Application of natural dyes on textiles, In: Indian Journal of Fiber \& Textile Research, 2009, 34, 4, 384-399

[17] Vankar, P.S., Dyeing Cotton, Silk and Wool yarn with extract of Garcinia mangostana pericarp, In: Journal of Textile and Apparel, Technology and Management, 2009, 6, 1, 326-335

[18] Ali, S., Nisar, N., Hussain, T., Dyeing properties of natural dyes extracted from eucalyptus, In: Journal of the Textile Institute, 2007, 98, 6, 559-562

[19] Wanyama, P.A.G., Kiremire, B.T., Ogwok, P., Murumu, J.S., The effect of different mordants on strength and stability of color produced from selected dye-yielding plants in Uganda, In: International Archive of Applied Sciences and Technology 2015, 1, 2, 81-92

[20] Kamel, M., Helmy, H., Hawary, N.E.I., Some studies on dyeing properties of cotton fabrics with crocus sativus (Saffron flowers) using an ultrasonic method, In: Journal of Natural Fibers, 2009, 6, 2,151-170 
[21] Sahoo, T., Bhattacharya, G., Dash, S.K., Effectiveness of Different Mordants and Concentrations on the Dyeing Properties of Jackfruit (Atrocarpus heterophyllus) Bark on Silk, In: International Journal of Agriculture, Environment and Biotechnology, 2017, 10, 5, 565-573

[22] Mongkholrattanasit, R., et al., Dyeing, fastness, and UV protection properties of silk and wool fabrics dyed with eucalyptus leaf extract by the exhaustion process, In: Fibers \& Textiles in Eastern Europe, 2011, 19, 94-99

[23] Borbély, É., Lyocell, the new generation of regenerated cellulose, In: Acta Polytechnica Hungarica, 2008, 5, 3, 11-18

[24] Sawalha, S.M., Arraez Roman, D., Segura Carretero, A., Fernandez Gutierrez, A., Quantification of main phenolic compounds in sweet and bitter orange peel using CE-MS/MS, In: Food Chemistry, 2009, 116, 2, 567-574

[25] Curl, A., Bailey, G., Orange Carotenoids, Part I-Comparison of Carotenoids of Valencia Orange Peel and Pulp, Part II-Carotenoids Aged Canned Valencia Orange Juice, In: Journal of Agricultural and Food Chemistry, 1956, 4, 2, 156-162

[26] Oreopoulou, V., Tzia, C., Utilization of plant by-products for the recovery of proteins, dietary fibers, antioxidants, and colorants, In: Utilization of by-products and treatment of waste in the food industry, Springer, 2007, 209-232

[27] Moussaid, M., Caillet, S., Nketsia Tabiri, J., Boubekri, C., Lacroix, M., Phenolic compounds and the colour of oranges subjected to a combination treatment of waxing and irradiation, In: Journal of the Science of Food and Agriculture, 2004, 84, 13, 1625-1631

[28] Hou, X., Chen, X., Cheng, Y., Xu, H., Chen, L., Yang, Y., Dyeing and UV-protection properties of water extracts from orange peel, In: Journal of cleaner production, 2013, 52, 410-419

[29] Kumar, C., Dhinakaran, M., Extraction and application of natural dyes from orange peel and lemon on cotton fabrics, In: Textile Research Journal, 2017, 80, 2117-2123

[30] Edeen, A.B., Dyeing of Egyptian Cotton Fabrics with Orange Peel Using Padding Technique, In: International Design Journal, 2015, 5, 3, 733-744

[31] Ahmed, I., Zia, M.A., Hussain, M.A., Akram, Z., Naveed, M.T., Nowrouzi, A., Bioprocessing of citrus waste peel for induced pectinase production by Aspergillus niger; its purification and characterization, In: Journal of Radiation Research and Applied Sciences, 2016, 9, 2, 148-154

[32] Maha-In, K., Mongkholrattanasit, R., Klaichoi, C., Pimklang, W., Buathong, P., Rungruangkitkrai, N., Dyeing Silk Fabric with Natural Dye from Longan Leaves Using Simultaneous Mordanting Method, In: Materials Science Forumm, 2016, 857, 491-494

[33] Sentthil Kumar, C.S., Dhinakaran, M., Extraction and Aapplication of Natural Dyes From Orange Peel and Lemon Peel on Cotton Fabrics, In: International Research Journal of Engineering and Technology, 2017, 4, 5, 237-244

[34] Hou, X., Chen, X., Cheng, Y., Xu, H., Chen, L., Yang, Y., Dyeing and UV-Protection Properties of Water Extracts from Orange Peel, In: Journal of Cleaner Production, 2013, 52, 410-419

Authors:

NAVEED TAYYAB ${ }^{1,2,3}$, RASHDI YASEEN SAYED ${ }^{1}$, REHMAN FAISAL $^{1}$, WEI WANG ${ }^{1,4}$, AWAN ASHRAF JAVEED ${ }^{3}$, ABBAS MUDASSAR ${ }^{3}$, FRAZ AHMAD ${ }^{3}$, AWAIS MUHAMMAD $^{2,5}$

${ }^{1}$ College of Chemistry, Chemical Engineering and Biotechnology, Donghua University, 201620, Shanghai, China

email: 414006@mail.dhu.edu.cn, sayedyaseenrashdi@outlook.com, faisal.dhu@qq.com

${ }^{2}$ School of Textile and Design, University of Management and Technology, Johar Town, 54770, Lahore, Pakistan

${ }^{3}$ Department of Textile Engineering \& Technology, University of the Punjab, 54590, Lahore, Pakistan

email: chairman.tet@pu.edu.pk; mudassar.abbas@umt.edu.pk, ahmad.fraz@umt.edu.pk

${ }^{4}$ Saintyear Holding Group Co., Ltd., Xiaoshan, Hangzhou, 311221, Zhejiang, China

${ }^{5}$ Institute of Textile Machinery and High Performance Material Technology,

TU Dresden, 01062 Dresden, Germany

email: muhammad.awais1@tu-dresden.de

Corresponding author:

WEI WANG

e-mail:wangv@dhu.edu.cn 


\title{
Social responsibility in the textile industry in Romania
}

\author{
DOI: 10.35530/IT.071.04.1676
}

NICOLETA ANDREEA NEACŞU

SIMONA BĂLĂŞESCU

MARIUS BĂLĂŞESCU CARMEN ELENA ANTON

\section{ABSTRACT - REZUMAT}

\section{Social responsibility in the textile industry in Romania}

In a sustainable society, the integration into the activity of entities of the actions from the sphere of social responsibility becomes more and more evident.

The study analyzes the textile industry in Romania in terms of social responsibility, the involvement of companies in this industry in asserting the values of this level. Thus, a quantitative marketing research is carried out at the level of the population in Romania, a piece of research which is aimed at identifying the opinions and attitudes of the citizens regarding the social responsibility adopted by the Romanian companies, with emphasis on the companies in the textile industry. In this research, particular attention was given to the comprehension of the reality of the aspects in which consumers perceive the requirements of social responsibility and of the way in which they function in practice. The results of this research can be used by the companies in the textile industry as well as by all the companies interested in this aspect in order to improve the quality of the services and of their implications in the social life and in order to respond to the needs of the citizens as well as possible.

Keywords: social responsibility, social ethics, consumer behaviour, quantitative research, textile industry

\section{Responsabilitatea socială în industria textilă din România}

Într-o societate sustenabilă, integrarea în activitatea entităţilor a acţiunilor din sfera responsabilităţii sociale se manifestă din ce în ce mai pregnant.

Studiul analizează industria textilă din România prin prisma responsabilității sociale, a implicării companiilor din această industrie în afirmarea valorilor pe acest palier. Astfel, se realizează o cercetare cantitativă de marketing la nivelul populației din România, cercetare care vizează cunoaşterea opiniilor și atitudinilor cetățenilor în legătură cu responsabilitatea socială adoptată de către companiile românești, cu accent pe companiile producătoare din industria textilă. În cadrul acestei cercetări o atenție deosebită s-a acordat cunoaşterii realității aspectelor în care consumatorii percep cerințele responsabilității sociale şi a modului în care acestea se manifestă în practică. Rezultatele acestei cercetări vor putea fi folosite de către companiile din industria textilă, dar și de către toate companiile interesate în acest sens, în vederea îmbunătățiii calității serviciilor oferite şi a implicării în viața socială şi pentru a răspunde cât mai bine nevoilor cetățenilor.

Cuvinte-cheie: responsabilitate socială, etică socială, comportamentul consumatorului, cercetare cantitativă, industria textilă

\section{INTRODUCTION}

The domain of textile industry is very well developed in Romania. Romania's overall international trade in 2015 was over 117.56 billion euro, 5.9\% more over 2014, according to the data provided by the Ministry of Economy. The export of textiles, leather and footwear exceeds 5 billion euro, which represents $11 \%$ of Romania's overall exports and it has over 250,000 employees. There are over 9700 companies operating in these sectors. In Romania this has been a traditional sector for more than 120 years, but it is also very innovative and creative. Highly qualified people work in the field of both design and technology. In the top 100 companies with $100 \%$ Romanian capital, there are 41 companies from the domain of textile industry [1].

The affirmation of social responsibility is outlined in the circumstances of the contemporary society as a requirement, as an ever growing necessity. In the day-to-day reality, the manifestation of the requirements of the components that form social responsibility has become an ethical and legal obligation for the commercial societies, imposed by the general interests of the community. When companies comply with and integrate these requirements into their business, they are perceived by the community as socially responsible companies.

Internationally, there are concerns to ensure a balance between moral and the personal interest of companies. The economic growth of a company does not involve only making profit, but also its reinvestment. CSR strategic approach represents a prerequisite for achieving business success [2].

Corporate social responsibility (CSR) is perceived as a new form of cooperation between governments, business and civil society, and the promotion of social objectives by companies has got economic implications (for business, by their increased power within 
the community), political (for governments, by increasing the control on companies, although not always directly) and social (for the various stakeholder groups). The ethical behaviour of a commercial company has as coordinates the trust- and respect-based relationships with its trading partners.

The novelty of the information presented in this paper consists of the approach of social responsibility from the point of view of the consumer, his/ her perception of the social responsibility in the context of the sustainable development of the society.

The study carried out by CSRMedia and Valoria Business Solution explores the perceptions of CSR managers and specialists from various companies in Romania in terms of the evolution, dynamics and challenges of this field in 2017 and 2018. The results show that in Romania the companies' involvement in this field has increased from $27 \%$ in 2017 , to $35 \%$ in 2018 [3]. By comparing it to our research on the views of the Romanian citizens on CSR, it has been found out that this concept is less known among consumers. This aspect requires a more active involvement of companies in CSR actions and better information and promotion of the initiatives.

\section{SOCIAL RESPONSIBILITY IN THE LITERATURE}

Corporate Social Responsibility (CSR) stands for the duty of companies to create a positive impact on society by the measures they adopt. Internationally, there are several types of CSR. According to the World Business Council for Sustainable Development, social responsibility is "a continuous commitment in the field of business, towards some ethical behaviour and towards its contribution to the economic development, along with an increase in the quality of life of the staff and their families, as well as for the local community and society as a whole" [4]. The European Commission defines corporate social responsibility as "a concept by which companies integrate social and environmental concerns into their commercial activities and interactions with other stakeholders, on a voluntary basis" [5]. The European Forum on corporate social responsibility in Europe, set up at the initiative of the European Commission, defines CSR as a concept by which companies integrate, voluntarily, social and ecological aspects in their business operations and in their interactions with their stakeholders [6]. Kotler and Lee have identified several types of corporate social responsibility practices that have worked over time and that have produced remarkable results at the organization level [7]. CSR is complementary to specific approaches in order to deliver enhanced social and environmental performance and it should not be understood as a legal substitute or as a task for the companies with public responsibilities, which mainly remain in the hands of governments [8-10].

The basic premise behind the CSR is that the profits, the people and the environment can be harmonized in a strategic corporate approach, so that the company becomes economically sustainable, socially responsible and attentive to environmental issues. It is considered that the integration of the aspects related to social responsibility by businesses in the adopted decisions and strategies brings along more benefits: reducing the costs associated to energy consumption and resources by implementing some ecological actions, by increasing the loyalty of employees and organizational citizenship behaviour by initiating programs for human resources development, by improving relations with governmental institutions [11-12].

Significant differences in CSR approach appear in the literature, where the authors have slightly differently perceived the responsibilities of a company to the society as a whole. Thus, the main debate in this area refers to two distinct concepts: CSR perceived as a moral obligation or duty towards a wider or narrower range of interest groups and the CSR as a voluntarily assumed initiative by companies to achieve social, but also economic objectives.

\section{RESEARCH METHODOLOGY}

In order to identify the attitude of the Romanian consumers regarding the social responsibility in the textile industry, a quantitative marketing research based on a sample of 428 respondents residing in Romania was carried out.

The main objective of the paper was to know the opinions and attitudes of the Romanian citizens in relation to the social responsibility adopted by the companies operating in Romania, with emphasis on the companies operating in the textile industry. Bearing in mind the topic of the paper, the research was based on several hypotheses, including:

- HO: At least $50 \%$ of Romanians are to a little extend familiar with CSR;

$\mathrm{H} 1$ : Less than $50 \%$ of Romanians are to a little extend familiar with CSR.

- HO: At most $50 \%$ of Romanians are satisfied with CSR actions organized by companies;

$\mathrm{H} 1$ : More than $50 \%$ of Romanians are satisfied with CSR actions organized by companies.

In this paper, the sampling method being non-aleatory, volunteer sampling of the respondents was carried out on the basis of a survey. For the collection the data, the survey method was used in the electronic format. The questionnaire (containing 20 questions) was designed on the Google Forms platform and it was distributed to Facebook groups with over 1500 members. Similarly, it has been distributed by means of the Instant Messaging application, Whatsapp. Being distributed online, the questionnaire collected 428 respondents, the researcher having no control over who answers it.

After having collected the information with the help of the questionnaire, the statistical data processing was done with the SSSP (Social Sciences Statistics Package) system. The first step was to define the relevant variables of the research. Afterwards, the response options were encoded in order to facilitate data computerization. The encoding was done 
according to each question and to the scale used for this question. The SSSP database was completed after all questionnaires were introduced and, in the end, the data were centralized as tables and graphs of frequency [13].

\section{RESEARCH RESULTS}

Although the practices of responsibility rendering in the Romanian corporate area have emerged as an import of values and principles taken from the European context, the indigenous companies have begun to assimilate and adapt them to the specificity of the organizational culture in Romania. Over the last three years we there has been a growing visibility of the CSR programs and there has been a large number of NGOs that promote on behalf of companies and with their financial aid various social causes [14]. In this context, it has become imperiously necessary to carry out research to provide an overview of the opinions of the Romanian citizens on the actions of companies in the sphere of social responsibility. The research has revealed a lot of information, the most relevant for the issues under consideration being presented below.

To the question referring to the understanding of the concept of "corporate social responsibility" (CSR), it is noticeable that $40.2 \%$ of the respondents know little about this concept, but a very close percentage of $30.7 \%$ know and understand to a great extent what CSR presupposes. Similarly, it is noted that $10.3 \%$ of the respondents know to some extent what CSR presupposes. The percentage of the people who do not know this concept at all is significant (19.6\%) (table 1 and figure 1).

Table 1

\begin{tabular}{|l|c|c|c|c|}
\hline \multicolumn{5}{|c|}{ BEING FAMILIAR TO CSR } \\
\hline Answers & Frequency & Percent & $\begin{array}{c}\text { Valid } \\
\text { percent }\end{array}$ & $\begin{array}{c}\text { Cumulative } \\
\text { percent }\end{array}$ \\
\hline Not at all & 84 & 19.6 & 19.6 & 19.6 \\
\hline $\begin{array}{l}\text { To a less- } \\
\text { er extent }\end{array}$ & 172 & 40.2 & 40.2 & 59.8 \\
\hline $\begin{array}{l}\text { To some } \\
\text { extent }\end{array}$ & 44 & 10.3 & 10.3 & 70.1 \\
\hline $\begin{array}{l}\text { To a large } \\
\text { extent }\end{array}$ & 112 & 26.2 & 26.2 & 96.3 \\
\hline $\begin{array}{l}\text { To a great } \\
\text { extent }\end{array}$ & 16 & 30.7 & 3.7 & 100.0 \\
\hline Total & 428 & 100.0 & 100.0 & - \\
\hline
\end{tabular}

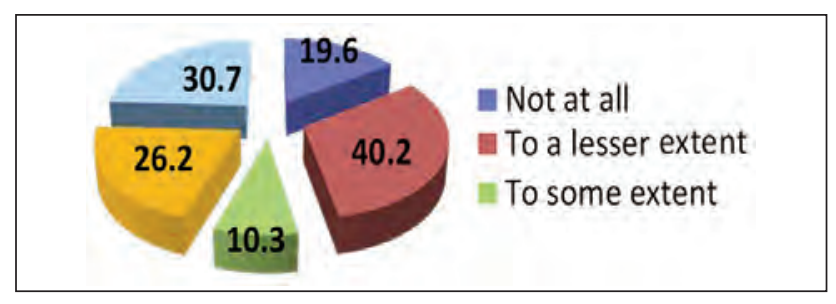

Fig. 1. Being familiar to CSR
Table 2

THE INVOLVEMENT OF ROMANIAN COMPANIES IN CSR

\begin{tabular}{|l|c|c|c|c|}
\hline Answers & Frequency & Percent & $\begin{array}{c}\text { Valid } \\
\text { percent }\end{array}$ & $\begin{array}{c}\text { Cumulative } \\
\text { percent }\end{array}$ \\
\hline Very poor & 32 & 7.5 & 7.5 & 7.5 \\
\hline Poor & 72 & 16.8 & 16.8 & 24.3 \\
\hline None & 172 & 40.2 & 40.2 & 64.5 \\
\hline Strong & 92 & 21.5 & 21.5 & 86.0 \\
\hline $\begin{array}{l}\text { Very } \\
\text { strong }\end{array}$ & 60 & 14.0 & 14.0 & 100.0 \\
\hline Total & 428 & 100.0 & 100.0 & \\
\hline
\end{tabular}

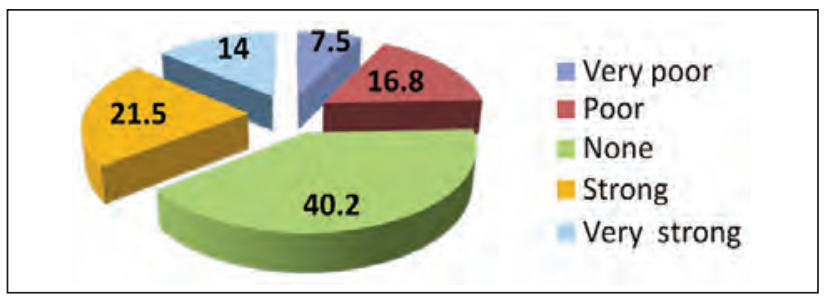

Fig. 2. The involvement of companies in CSR

The respondents' opinions on the involvement of Romanian companies in CSR actions are highlighted in table 2 and figure 2.

It can be noted that most of the respondents, $40.2 \%$ chose the option "None", which means that they have a neutral opinion regarding the involvement of Romanian companies in solving the problems the Romanian society faces. On the second place, by $21.5 \%$ are those who have a "strong" opinion, meaning they are interested in this topic. Summed up, the opinions of those who chose the "Strong" and "Very strong" variants make up $35.5 \%$, surpassing the opinions of those who chose the "Poor" and "Very poor" versions of $24.3 \%$. Therefore, this area is one that is not currently in the area of interest of the population. To the question "What sources did you hear about corporate social responsibility from?", the respondents offered various answers that are highlighted in table 3 and figure 3 . The majority of respondents, $41.1 \%$ found out about this concept from "the Internet", to be more precise, 176 out of 428 persons. It is important to highlight that 38 people have heard about this concept from the questionnaire they filled in. A percentage of $9.3 \%$ respondents heard about this concept from the faculty, and $7.5 \%$ of the respondents have never heard about the CSR concept, at all. The statement "Romanian companies are actively involved in helping the citizens", the highest share is the category "Disagree" with 120 respondents, very close to the "Agree" category, which has got 188 answers. This balance may be the result of the lack of sufficient knowledge of the meaning of the concept CSR by the Romanian population.

Referring to the situation when "Romanian companies are interested in profit and not in citizen welfare", a significant number of respondents, namely 168 


\begin{tabular}{|l|c|c|c|c|}
\hline \multicolumn{5}{|c|}{ SOURCES OF INFORMATION ON CSR } \\
\hline Answers & Frequency & Percent & $\begin{array}{c}\text { Valid } \\
\text { percent }\end{array}$ & $\begin{array}{c}\text { Cumulative } \\
\text { percent }\end{array}$ \\
\hline Television & 84 & 19.6 & 19.6 & 19.6 \\
\hline Internet & 176 & 41.1 & 41.1 & 60.7 \\
\hline Hoardings & 24 & 5.6 & 5.6 & 66.4 \\
\hline Radio & 20 & 4.7 & 4.7 & 71.0 \\
\hline Faculty & 40 & 9.3 & 9.3 & 80.4 \\
\hline $\begin{array}{l}\text { This ques- } \\
\text { tionnaire }\end{array}$ & 36 & 8.4 & 8.4 & 88.8 \\
\hline Others & 16 & 3.7 & 3.7 & 92.5 \\
\hline $\begin{array}{l}\text { Never } \\
\text { heard of }\end{array}$ & 32 & 7.5 & 7.5 & 100.0 \\
\hline Total & 428 & 100.0 & 100.0 & - \\
\hline
\end{tabular}

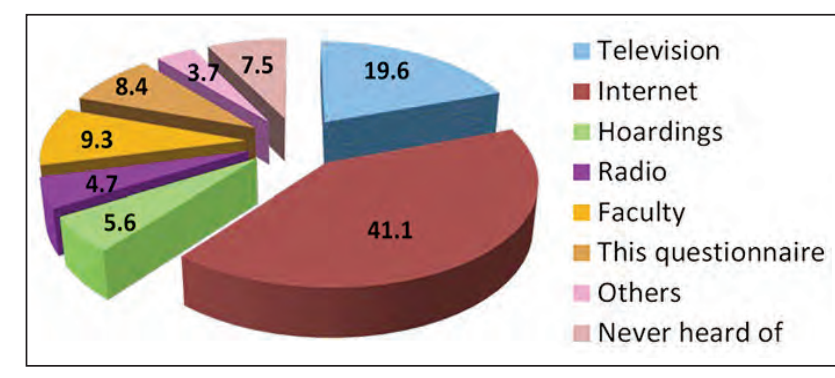

Fig. 3. Sources of information on CSR

to involve in actions of social responsibility and of support for these actions is easily noticeable (table 4). The following responses were given to the question on mentioning the name of a company in the textile industry involved in social responsibility activities, according to the following table (table 5). Thus, the

THE DEGREE OF AGREEMENT OR DISAGREEMENT ON CSR ACTIONS

\begin{tabular}{|l|c|c|c|c|c|}
\hline \multicolumn{1}{|c|}{$\begin{array}{c}\text { The degree of agreement or disagreement } \\
\text { with concern to the following statements }\end{array}$} & $\begin{array}{c}\text { Totally } \\
\text { disagree }\end{array}$ & Disagree & $\begin{array}{c}\text { Neither agree } \\
\text { nor disagree }\end{array}$ & Agree & $\begin{array}{c}\text { Totally } \\
\text { agree }\end{array}$ \\
\hline $\begin{array}{l}\text { Romanian companies are actively involved in helping } \\
\text { citizens }\end{array}$ & 44 & 120 & 44 & 188 & 32 \\
$\begin{array}{l}\text { Romanian companies are interested in profit and not } \\
\text { in citizen welfare }\end{array}$ & 12 & 72 & 48 & 168 & 128 \\
\hline $\begin{array}{l}\text { I think there are more and more companies involved } \\
\text { in social responsibility activities }\end{array}$ & 20 & 144 & 32 & 192 & 40 \\
\hline $\begin{array}{l}\text { Corporate social responsibility is a beneficial aspect } \\
\text { for the society }\end{array}$ & 4 & 12 & 44 & 132 & 236 \\
\hline $\begin{array}{l}\text { I am willing to pay more for a product purchased from a } \\
\text { company that is involved in social responsibility activities }\end{array}$ & 20 & 96 & 40 & 140 & 132 \\
\hline
\end{tabular}

respondents, stated that they agreed with this statement, only 12 people totally disagree with the given assertion.

For the opinion "I consider that there are more and more companies involved in social responsibility activities", 192 persons "Agree", in total contrast being the statement of total disagreement from 20 respondents.

The following statement "Corporate social responsibility is a positive thing for society" gathered the majority of respondents, 236 people for the "Totally agree" answer, which means that the population is aware of the increasing importance of CSR.

For the statement "I am willing to pay more for a product purchased from a company involved in social responsibility activities", the opinions of the interviewees are divided between "Agree" answers from 140 respondents and "Totally agree" with a total of 132 respondents. Thus, people's desire
Table 5

DISTRIBUTION OF COMPANIES IN THE TEXTILE INDUSTRY INVOLVED IN CSR ACTIVITIES IN THE OPINION OF THE CITIZENS

\begin{tabular}{|l|c|c|c|c|}
\hline \multicolumn{1}{|c|}{ Answers } & Frequency & Percent & $\begin{array}{c}\text { Valid } \\
\text { percent }\end{array}$ & $\begin{array}{c}\text { Cumulative } \\
\text { percent }\end{array}$ \\
\hline SC Rifil SA & 64 & 15.0 & 15.0 & 15.0 \\
\hline SC Rosko Textil SRL & 52 & 12.1 & 12.1 & 27.1 \\
\hline SC Moden SRL & 40 & 9.3 & 9.3 & 36.4 \\
\hline SC Benrom SRL & 20 & 4.7 & 4.7 & 41.1 \\
\hline SC Formens SRL & 16 & 3.7 & 3.7 & 44.9 \\
\hline SC Biancospino SRL & 4 & 0.9 & 0.9 & 45.8 \\
\hline SC Pandora Prod SRL & 8 & 1.9 & 1.9 & 47.7 \\
\hline SC Paola Confectii SRL & 12 & 2.8 & 2.8 & 50.5 \\
\hline SC ITS Production SRL & 12 & 2.8 & 2.8 & 53.3 \\
\hline SC Coats Odorhei SRL & 4 & 0.9 & 0.9 & 54.2 \\
\hline SC Coindu Romania SRL & 84 & $1 ., 6$ & 19.6 & 73.8 \\
\hline DC Cottontex SRL & 4 & 0.9 & 0.9 & 74.8 \\
\hline Others & 12 & 2.8 & 2.8 & 77.6 \\
\hline I don't know & 96 & 22.4 & 22.4 & 100.0 \\
\hline Total & 418 & 100.0 & 100.0 & - \\
\hline
\end{tabular}


most well-known company, from the point of view of the citizens, is SC Coindu Romania SRL with $19.6 \%$, followed by SC Rifil SA with $15 \%$, followed by SC Rosko Textil SRL with $12.1 \%$. They are known by citizens as companies that get involved in CSR activities. It can be noticed that $22.4 \%$ of the respondents said that they do not know companies in this industry that are involved in CSR actions.

Similarly, for the statement "Do you think that CSR is well served in the textile industry in our country?", it is to be noticed that $42.1 \%$ of the respondents answered "Neither agree nor disagree", which may mean that they do not have all the information about these actions or that they are not convinced of the seriousness of these actions. At the same time, $24.3 \%$ of the respondents agree with the statement and $14 \%$ are in total agreement with this statement (table 6).

of satisfaction of the population results from the thorough ignorance of the concept and its role in society. At the declarative level, the population agrees to be socially responsible, but to have a minimal to nonexistent involvement, so that the population places responsibility on companies [15].

\section{CONCLUSIONS}

Any economic entity, including those in the textile industry, prior to integrating into its activity social responsibility actions, gets down to a profitability analysis based on financial reporting. Their impact becomes evident in the level of registered expenditures, such as: social expenses, education expenses, expenses for the development of sports, cultural actions, etc. The fundamental orientation is coordinated by the tax mechanisms provided by the tax legislation [16-17]. Thus, the entities are interested in tax facilities they can benefit from in carrying out social responsibility activities, and tax deductions are the tax instrument most commonly used by the national regulator. Yet, the very complex and unstable tax legislation triggers a less-present behaviour of entities on this level. The combination of the patrimonial interests with the charitable actions aimed, in fact, at improving

When asked about the respondents' decision to buy products mainly from some companies in the textile industry that are environmental-friendly and to pay a higher price for them, the questioned respondents answered affirmatively in a very high percentage, more exactly $91.6 \%$, while only $8.4 \%$ say they do not take this aspect into consideration when purchasing textiles (figure 4).

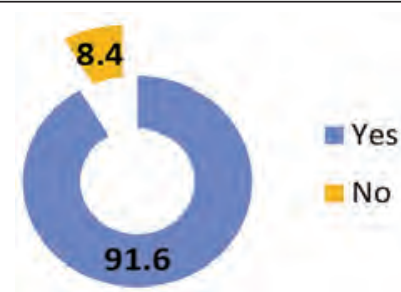

Fig. 4. Consumers' desire to pay a higher price for the environmentally friendly products

Two very important hypotheses have been confirmed, namely, that at most $50 \%$ of Romanians are satisfied with CSR actions organized by the companies in the textile industry in our country, and the hypothesis which claims that at most $50 \%$ of the Romanians are familiar to a little extent to the term CSR. That is why it is possible that this high degree the public image of the entity and, implicitly, at reducing human resource costs [18]. The companies in the textile industry, by tackling with innovative solutions and interest paid to environmental actions, contribute to the sustainable development, a dimension of social responsibility.

If a company does not appeal to consumers, partners, community in the development process, then its profitability and competitiveness will suffer in the long run. CSR aims to ensuring a better connection between the society/community responsibility and the long-term financial objectives of the companies [19]. There are specialists who claim that CSR generates far too high costs in social investments without visible effects, but this concept has to be understood and promoted in terms of long-term benefits without minimizing its strategic role. Communication is an important element of CSR which guarantees transparency for the interested groups. The promoted social programs, however, should not be viewed solely from the perspective of PR and marketing benefits they bring. In setting up the CSR strategy, the companies should start from the community's real needs and afterwards it should define its measurable and honest objectives.

The results of the research are meant to outline the directions of action that companies should introduce 
into their overall business strategy so that the end consumer perceives them as an ally in the sustainable social development. Consumer attitudes and opinions on CSR lead to the need for active visibility for consumer assimilation and understanding.

As a result of the study, it was found only in the reports of the large companies that CSR actions were carried out. In case the small and medium-sized companies have been involved in CSR activities, they are not visible and cannot be known to the general public.

The authors recommend to the managers of the companies a gradual manifestation of the actions regarding the essential values promoted for the improvement of the quality of life and for the optimization of the environmental performance. Similarly, large entities also must be consistent with the observance of the principles of integrated reporting, according to which the transmitted information can be perceived and respond to the needs of consumers.
The limits of the study consist in the inexistence of some reports containing CSR actions undertaken by small and medium-sized companies in Romania. Keeping in mind these limitations, we recommend including CSR actions carried out by small and medium-sized companies in administrators' annual reports.

A future research direction could consist in conducting qualitative research among the managers of companies in Romania in order to study the correlations between the consumers' and managers' opinions on the CSR concept.

The analysis emphasizes the necessity of integrating social responsibility components by the economic entities as an ethical and legal obligation imposed by the general interests of the community for some sustainable development. The attitude of complying with the CSR requirements convinces the community to perceive them as socially responsible societies.

\section{REFERENCES}

[1] The European Way, Corporate social responsibility in the European Union and the fight against poverty: the example of the textile industry in Romania, Available at: https://www.caleaeuropeana.ro/live-video-6-mai-ora-11-00responsabilitatea-sociala-a-intreprinderilor-in-uniunea-europeana-si-combaterea-saraciei-exemplul-industrieitextile-din-romania-in-cadrul-eurosfat-2016/ [Accessed November 7th 2018]

[2] Mohamed, W.S., Arafa, I.M., Investigating corporate social responsibility disclosure by banks from institutional theory perspective, In: Journal of Administrative and Business Studies, 2016, 2, 6, 280-293

[3] CSR Media, Studiu CSR: 35\% dintre companii spun că Responsabilitatea Socială face parte din filosofia firmei, Available at: https://www.csrmedia.ro/studiu-csr-35-dintre-companii-spun-ca-responsabilitatea-sociala-face-partedin-filozofia-firmei/ [Accessed November 9th 2018]

[4] Social Responsibility (Corporate) in Romania, Available at: http://www.csrmedia.ro/wp-content/uploads/2013/ 01/Analiza-Situatiei-RSC-in-Romania-RO1.pdf [Accessed November 9th 2018]

[5] European Commission - Directorate General for Small and Medium Enterprises, Internal Market, Industry, Entrepreneurship and SMEs, Available at: https://ec.europa.eu/info/departments/internal-market-industryentrepreneurship-and-smes_ro [Accessed November 7th 2018]

[6] CSR EMS Forum, Final Report, 2004, Available at: http://www.indianet.nl/EU-MSF_CSR.pdf [Accessed October 22th 2018]

[7] Kotler, P., Lee, N., Coroprate Social Responsibility. Doing the Most Good for your Company and your Cause, In: New Jersey Published by John Wiley \& Sons, 2005, 198-234

[8] lamandi, I.E., Jolde, C.S.R., Corporate social responsibility during the economic crisis. The case of Romanian companies, In: Annals of Faculty of Economics, 2010, 1, 2, 963-969

[9] Filip, R., Iamandi, I., Etică și responsabilitate sociala corporativă în afacerile internaționale, In: Bucharest, ASE Publishing, 2008, 134-136

[10] Dewi, N.I.K., Mataram, I.G.A.B., Siwantara, I.W., Validating a framework of the integration of corporate social responsibility and culture: The case of hotel industry, In: International Journal of Business and Economic Affairs, 2017, 2, 1, 31-44

[11] Olaru, M., Stoleriu, G., Sandru, I.M.D., Social Responsibility Concerns of SMEs in Romania, from the Perspective of the Requirements of the EFQM European Excellence Model, In: Amfiteatru Economic, 2011, 13, 29, 57-72

[12] Hassan, R., Exploring the association of corporate social responsibility and employees' organisational citizenship behaviour: A study in Pakistan, In: Journal of Administrative and Business Studies, 2018, 4, 1, 27-40

[13] Anton, C., Consideration related to the attitudes, behaviours and opinions of the managers of the micro, small and mesium entreprises of Brasov, related to the tender of the financial-accounting services companies, In: Proccedings of the International Conference on Business Excellence, 2010, 14-18

[14] Obrad, C., Petcu, D., Ghergheș, V., Suciu, S., Corporate Social Responsibility in Romanian Companies - between Perceptions and Reality, In: Amfiteatru Economic, 2011, 13, 29, 54

[15] Madar, A., Neacşu, N.A., Protection of tabacco consumers and no consumers, In: Proccedings of the International Conference on Business Excellence, 2009, 259-262

[16] Culiuc, E., Mecanisme fiscale de stimulare a filantropiei, In: Chișinău, 2011, Available at: https://www.expertgrup.org/ro/biblioteca/item/332-mecanisme-fiscale-de-stimulare-a-filantropiei [Accessed October 27th 2018]

[17] Bălăşescu, M., Bălăşescu, S., The assertion of consumption goods distribution marketing in retail companies, In: Proccedings of the International Conference on Business Excellence, 2010, 46-48 
[18] Pahayahay, A.B., Asejo, N.R., Pangan, S.M., Dasig Jr., D.D., Panganiban Jr., A.S., A concurrent exploratory study on sectoral engagement model of an altruistic corporate social responsibility in bureau of jail management and penology, In: International Journal of Business and Economic Affairs, 2017, 2, 2, 98-105

[19] Alshannag, F., Basah, M.Y.A., Khairi, K.F., The relationship between corporate social responsibility and corporate financial performance A survey of literature, In: International Journal of Business and Administrative Studies, 2017, 3, 1, 9-15

\section{Authors:}

NICOLETA ANDREEA NEACȘU, SIMONA BĂLĂȘESCU, MARIUS BĂLĂȘESC, CARMEN ELENA ANTON

Transilvania University of Brașov, Faculty of Economics Sciences and Business Administration, Colina Universității no.1, 500084, Brașov, Romania e-mail: f-seaa@unitbv.ro

Corresponding author:

NICOLETA ANDREEA NEACȘU

e-mail: deea_neacsu@yahoo.com 


\section{Examining causality between market share and competitiveness: case study textile industry}

DOI: 10.35530/IT.071.04.1727

NIKOLA V. ĆURČIĆ

NIKOLA RADIVOJEVIĆ

ALEKSANDAR GRUBOR

ZORAN D. SIMONOVIĆ

\section{ABSTRACT - REZUMAT}

\section{Examining causality between market share and competitiveness: case study textile industry}

The paper dealt with the existence of causality in Granger's sense between competitiveness and market share, and vice versa, on emerging markets so as to answer the question whether it is possible to forecast the movement of the market share of an enterprise based on the data about the movement of the competitiveness of that enterprise. The research study was carried out on 96 textile companies from Serbia, Montenegro, and Bosnia and Herzegovina. The results of research have shown that relationship between competitiveness and market share is generally weak and in many industrial sectors it is nonexistent. In other words, the research results reveal that the existence of causality in Granger's sense between competitiveness and market share on the selected emerging markets depends on the branch of textile industry.

Keywords: market share, competitiveness, emerging markers, Granger causality, textile industry

Analiza cauzalității dintre cota de piață și competitivitate: studiu de caz industria textilă

Lucrarea dezbate existența cauzalității în sensul lui Granger, între competitivitate și cota de piață, și viceversa, pe piețele emergente, astfel încât să răspundă la întrebarea dacă este posibil să se prevadă evoluția cotei de piață a unei întreprinderi bazată pe datele despre evoluția competitivității întreprinderii. Studiul de cercetare a fost realizat pe 96 de companii textile din Serbia, Muntenegru și Bosnia și Herțegovina. Rezultatele cercetărilor au arătat că relația dintre competitivitate și cota de piață este în general slabă și în multe sectoare industriale este inexistentă. Cu alte cuvinte, rezultatele cercetării demonstrează că existența cauzalității în sensul lui Granger între competitivitate și cota de piață pe piețele emergente selectate depinde de ramura industriei textile.

Cuvinte-cheie: cota de piață, competitivitate, markeri emergenți, cauzalitate Granger, industria textilă

\section{INTRODUCTION}

Relevant research studies show a strong connection and causality between market share and competitiveness. In business practice and academic circles, there is a widespread understanding that a big market share automatically implies a great market power and competitiveness. This conventional understanding is founded on the assumption that a profitable increase in the price in function of the improvement of an organization's business success is more likely to occur in the organizations which have a bigger than in those which have a smaller market share. For that reason, there is also a widespread and colloquial understanding that the growth of market share also means the growth of competitiveness and vice versa. Numerous studies carried out in the late $20^{\text {th }}$ and in the early $21^{\text {st }}$ centuries have been supportive of the attitude as this one, indicating that the majority of the organizations with a big market share were enjoying above-average profit margins and competitiveness. Some research studies conducted in the late 1980s, however, showed that the companies with a low market share could also be successful and competitive in certain environments, and that sometimes a fall in market share is also a result of a preconcerted policy to improve profitability and competitiveness. The summary conclusion of those research studies is indicative of certain limitations in a sense that the growth of the market share of organizations in different industries cannot serve as a recipe for an increase in competitiveness.

The fact that they were exclusively conducted on the markets of developed countries and that their conclusions relate to the organizations having been operating in mature industries is characteristic of the previously mentioned research studies. A very small number of the studies are dedicated to researching causality between the growth of market share and competitiveness on emerging markets [1]. Therefore, a question is posed if the conclusions of these research studies are also valid for emerging markets (transitory economies) on which numerous irregularities and regularities in the functioning of the market which are in opposition to the laws of Smith's "invisible hand".

For that reason, this paper is aimed at examining causality in Granger's sense between the movement 
of market share and the competitiveness of the organizations operating on emerging markets, such as the Serbian, Montenegrin and Bosnian-Herzegovinian economies are, so as to answer the question whether it is possible to forecast the profit movement on the basis of the market share movement, and vice versa.

\section{LITERATURE REVIEW}

There are a large number of the papers dealing with the study of the impact of market share on organizations' performances, i.e. their competitiveness. The first studies were done as early as in the 1970s and the 1980s. Some of the best-known studies of those times are the research studies conducted by Schoeffler et al. [2], Buzzell [3], Newton [4] etc. They show statistically relationship between market share and competitiveness and profitability.

Apart from these studies, however, research studies such as a research study by Hamermesh and Anderson [5], which refer to the conclusion that enterprises with small market shares can also achieve above-average profits. Similar conclusions were also reached by Chawla et al. [6], Chandler and Hanks [7].

There are also the studies that found no existence of any connection whatsoever between market share and competitiveness. Such research studies were carried out by Boulding and Staelin [8], Jacobson [9] and Wensley [10], Schmalensee [11], Mueller [12]. Jacobson [9] concluded that although there may be a direct relationship between market share and competitiveness, it may be a spurious relationship [13]. The results of research were conducted by Faria and Wellington [14] show the existence of a significantly and positively correlated relationship, but the strength of the relationship was not as strong as suggested by the PIMS findings. Amburgey et al. [15], Sheth and Sisodia [16] found the proofs in favor of the U-shaped relationship between these two variables. By applying panel analysis, Genchev [17] confirmed the positive connection between market share and competitiveness. Similar research studies were conducted by Etale, Bringilarz and Ifuruezes [18], Goddard et al. [19], Pattitoni et al. [20], Leverty [21]. The foregoing is indicative of the fact that although there are a large number of the papers dealing with the study of the relationship between market share and the competitiveness.

\section{THEORETICAL BACKGROUND OF THE ISSUE IN THE CONTEXT OF THE METHODOLOGY USED}

In the context of the subject matter of the research of this paper, the application of the Granger causality test would imply that based on a set of data on the movement of companies' market share it would be possible to forecast a future movement of companies' competitiveness better than only conducting such forecast on the basis of the time series of the historical data about the profit movement. In other words, on the assumption that there is an available set of information about the movement of the market share $(x)$ of a certain company and its competitiveness, which is expressed through profit $(y)$ at a certain moment $(t)$ (the information set $\left.\Omega_{t}\right)$ of the form $\left(x_{t}, \ldots\right.$, $\left.x_{t-j}, y_{t}, \ldots, y_{t-i}\right)$, the data about market share at the moment $(t)\left(x_{t}\right)$ can be said to be Granger-causal for the company's profit data $\left(y_{t}\right)$ wrt. $\Omega_{t}$ if the variance of the optimal linear predictor for predicting a profit at the moment $t+h\left(y_{t+h}\right)$, based on the available set of pieces of information at the moment $(t)\left(\Omega_{t}\right)$ has a smaller variance than the optimal linear predictor for $y_{t+h}$ only based on the data about the movement of the profit from the prior period, for any $h$. For the reason of the said, the data about the market share of a company $(x)$ can be said to Granger-cause $y$ if, and only if $\sigma_{1}^{2}\left(y_{t}: y_{t-j}, x_{t-i}\right)<\sigma_{2}^{2}\left(y_{t}: y_{t-j}\right)$, with $j$ and $i=1,2$, $3, \ldots, n$, and $\sigma^{2}$ representing the variance of the forecast error.

In this paper, the first type of the Granger causality test is used given the fact that the paper is aimed at examining whether it is possible to forecast a future movement of companies' profits on the basis of the data on their market share and vice versa.

Bearing in mind the foregoing, the following equations are tested in the paper:

$$
\begin{gathered}
M S_{t}=\alpha+\sum_{t=1}^{m} \beta_{i}(M S)_{t-i}+\sum_{j=1}^{n} \tau_{j}(P f)_{t-j}+\mu_{t} \\
P f_{t}=\theta+\sum_{t=1}^{p} \phi_{i}(P f)_{t-i}+\sum_{j=1}^{q} \psi_{j}(P f)_{t-j}+\eta_{t}
\end{gathered}
$$

where: $P f$ is the profit rate, $M S$ - market share rate, $\mu$ and $\eta-$ residuals which are assumed to $\mu$ and $\eta \sim$ IID $N(0,1)$.

Based on the written equations, the following four hypotheses are possible to test by applying the OLS estimator:

1. There is unidirectional causality from a change in market share towards a change in the profit rate, i.e. change in a company's market share increases the forecasting of change in the company's profit rate, but not vice versa, so that:

$$
\sum_{j=1}^{n} \tau_{j} \neq 0 \text { and } \sum_{j=1}^{q} \psi_{j}=0
$$

2. There is unidirectional causality from a change in the profit rate towards a change in a company's market share, i.e. change in the profit rate of the company increases the forecasting of change in its market share, but not vice versa, thus:

$$
\sum_{j=1}^{n} \tau_{j}=0 \text { and } \sum_{j=1}^{q} \psi_{j} \neq 0
$$

that there is bidirectional (or feedback) causality:

$$
\sum_{j=1}^{n} \tau_{j} \neq 0 \text { and } \sum_{j=1}^{q} \psi_{j} \neq 0
$$

This means that based on change in a company's market share it is possible to forecast change in the company's profit rate, and vice versa.

3. There is no Granger causality in any direction whatsoever, i.e. that: 


$$
\sum_{j=1}^{n} \tau_{j}=0 \text { and } \sum_{j=1}^{q} \psi_{j}=0
$$

By proving one of these theses enables us to answer the question: is it possible to reliably forecast a future movement of a company's profit rate based on the movement of or change in the company's market share on the selected developing markets (in transitory economies), and vice versa.

\section{EMPIRICAL ANALYSIS}

The research study includes 96 companies from Serbia, Montenegro, and Bosnia and Herzegovina. Apart from the fact that these three states are in a similar phase of the development of their respective economies, i.e. the transition process, the EU accession phase, similar legal regulations from within the economic field and that they all have a common historical economic heritage, it is also characteristic of them that a large number of the companies from these states simultaneously do business in all the three states. The data were collected for the period from 2005 to 2018 through the Business Registers Agency, or the Chambers of Commerce. The selected companies belong to the six popular branches of the textile industries namely: the wool industry, knitwear industry, the apparel industry, the footwear industry, the carpet industry and the artificial fiber industry and from IT sector of design of textile. For the reason of the protection of the data, the paper presents the data of only those companies for which consents were obtained, or whose data are publicly available according to the respective laws of these countries, simultaneously paying attention to the presenting of the sample (the presented data and results of the analysis) that will represent the overall results of the analysis as truly as possible. Competitiveness is expressed by the profit annual rate.

The first step in the application of the Granger causality test implied the examination of the stationarity of the time series and the determination of the number of the unit roots (the order of integration). For that purpose, the ADF test was used in the paper, mentioning that the $\sqrt[3]{T}$ rule, i.e. the application of the Bretl kernel, was used to determine the maximum lag. While applying the ADF test, attention was paid to whether a series had a trend and also if it oscillated around the constant or not. Such a situation is recorded in about $87 \%$ of the time series. Just slightly over one-third of the time series had a problem with non-stationarity, that being so almost in an equal number in both series. More exactly, in 35 examined companies, at least one of the time series had the non-stationarity problem in level data. In the seven companies, the series were still nonstationary after the application of the first difference technique. No sooner had the second-order differentiation been applied than these series became stationary. It is interesting that there were no examples of both series in the same company being nonstationary at the second level. In the case of 28 companies, both series were nonstationary at the same basic level.
The greatest number of the nonstationary series were recorded in the sector of the the footwear industry, which can also be explained by great instability in this sector as a consequence of the transition process that has had an influence on the liquidation and restructuring of a huge number of big companies from within this sector and the occurrence of a large number of smaller-sized companies, which continued to do business with different successes. In the case when the series were nonstationary at the same level, the cointegration test was done. For that purpose, the Engel-Granger cointegration test was used. Such an example was recorded in the TSS company from within the footwear industry, whose results of the Engel-Granger cointegration test as an adequate representative for this type of analysis are shown in table 1.

Table 1

THE RESULTS OF THE ENGEL-GRANGER COINTEGRATION TEST

Step 1. Cointegrating regression - OLS, using the observations from 2005 to $2018(T=14)$ Dependent variable: Profitability

\begin{tabular}{|c|c|c|c|c|}
\hline Indicator & Coefficient & Std. error & t-ratio & $p$-value \\
\hline Const. & 0.268 & 0.138 & 1.936 & $0.0767^{*}$ \\
\hline M. share & 0.275 & 0.280 & 0.983 & 0.345 \\
\hline & & 0.074 & $\begin{array}{l}\text { Adjusted } \\
\text { R-squared }\end{array}$ & -0.003 \\
\hline
\end{tabular}

Step 2: testing for a unit root in uhat, Augmented Dickey-Fuller test for uhat, testing down from 2 lags, criterion AIC, the sample size 12; unit-root null hypothesis: $\mathrm{a}=1$

\begin{tabular}{|l|c|}
\hline model: $(1-\mathrm{L}) \mathrm{y}=(\mathrm{a}-1)^{*} \mathrm{y}(-1)+\ldots+\mathrm{e}$ \\
\hline estimated value of $(\mathrm{a}-1):$ & -1.319 \\
\hline test statistic: tau_c(2) & -3.767 \\
\hline asymptotic p-value & 0.015 \\
\hline 1st-order autocorrelation coefficient for e: & 0.083
\end{tabular}

Note: The length of the lag was chosen in the same manner as in the case of the ADF test, mentioning that a test-down from the maximum lag order was done.

The results of the Engel-Granger cointegration test indicate the existence of cointegration for the significance level of $1 \%$. Such a result was recorded in $13.54 \%$ of the examined companies. According to Sim, Stock and Watson (1990), in the case of the presence of cointegration between the variables the VECM model was used instead of the VAR model. The results of the VECM model on the example of this company are accounted for in table 3 below.

The second step in the application of the Granger causality test implied the determination of the optimal lag length. In the majority of the prior research studies, the lag length was arbitrarily determined. More recent research studies, however, have been emphasizing the significance of the regular determination of the lag length. Therefore, the three information criteria - namely the Akaike criterion, the Schwarz Bayesian 


\begin{tabular}{|c|c|c|c|c|c|}
\hline \multicolumn{6}{|c|}{ THE RESULTS OF THE GRANGER CASUALIITY TEST IN THE VAR MODELS } \\
\hline \multirow{2}{*}{ Company name } & \multirow{2}{*}{$\begin{array}{l}\text { Hypothesis } \\
\left(\mathrm{H}_{0,1}, \mathrm{H}_{0,2}\right)\end{array}$} & \multirow{2}{*}{ Stat. } & \multirow{2}{*}{ p-value } & \multicolumn{2}{|c|}{ p-value } \\
\hline & & & & Autocorr. & ARCH \\
\hline \multirow{2}{*}{ Wool industry Ltd } & Pf does not Granger-cause MS & $F(2,7)=0.767$ & 0.500 & \multirow{2}{*}{0.530} & \multirow{2}{*}{0.868} \\
\hline & MS does not Granger-cause Pf & $F(2,7)=0.839$ & 0.471 & & \\
\hline \multirow{2}{*}{ Ovium Ltd } & Pf does not Granger-cause MS & $F(2,7)=0.745$ & 0.509 & \multirow{2}{*}{0.380} & \multirow{2}{*}{0.477} \\
\hline & MS does not Granger-cause Pf & $F(2,7)=1.199$ & 0.357 & & \\
\hline \multirow{2}{*}{ Knitwear industry Ltd } & Pf does not Granger-cause MS & $F(2,7)=3.006$ & 0.114 & \multirow{2}{*}{0.444} & \multirow{2}{*}{0.938} \\
\hline & MS does not Granger-cause Pf & $F(2,7)=1.744$ & 0.243 & & \\
\hline \multirow{2}{*}{ Becomlabs Ltd } & Pf does not Granger-cause MS & $F(3,4)=0.717$ & 0.591 & \multirow{2}{*}{0.463} & \multirow{2}{*}{0.544} \\
\hline & MS does not Granger-cause Pf & $F(3,4)=6.309$ & 0.054 & & \\
\hline \multirow{2}{*}{$\begin{array}{l}\text { Artificial fiber industry } \\
\text { Ltd }\end{array}$} & Pf does not Granger-cause MS & $F(1,10)=0.021$ & 0.888 & \multirow{2}{*}{0.847} & \multirow{2}{*}{0.866} \\
\hline & MS does not Granger-cause Pf & $F(1,10)=0.357$ & 0.563 & & \\
\hline \multirow{2}{*}{ Apparel industry Ltd } & Pf does not Granger-cause MS & $F(2,7)=2.568$ & 0.146 & \multirow{2}{*}{0.380} & \multirow{2}{*}{0.477} \\
\hline & MS does not Granger-cause Pf & $F(2,7)=2.260$ & 0.175 & & \\
\hline
\end{tabular}

Note: In the last two columns in the table, the p-values of the autocorrelation test and the ARCH effect of the tested VAR models are shown. Autocorrelation and the presence of the $\mathrm{ARCH}$ effect is not recorded in one single company, which clearly indicates the correctness of the VAR models. $\mathrm{H}_{0,1} \mathrm{H}_{0,2}$ are the null hypotheses for the first, or the second variable, respectively.

criterion, and the Hannan-Quinn criterion - were used in the paper for that purpose. Given the fact that these criteria can generate different lag lengths, when making a selection between them, attention was paid to the fact that the choice of the optimal lag length should be a compromise between the lag length and the number of the parameters since it is known that the number of the parameters in the system quickly grows as the length increases, whereas, on the other hand, a small lag length can lead to a misspecification problem. The optimal lag length was mainly 2 . In the case of 14 companies, according to the given criteria, the optimal lag length was 3, whereas 13 had the optimal lag 1 .

Table 2 accounts for the results of the Granger causality test in the VAR models, whereas table 3 accounts for the results of the VECM model of the selected company. Based on the results shown in table 2, it is possible to notice that in the largest number of the cases it was recorded that the series do not Granger-cause one another. The analysis of the application of the VECM model indicates that it was found in the majority of the cases (in 7 companies) that the residual was statistically significant for the competitiveness variable, which means that competitiveness is not weakly exogenous and that it moves to restore the equilibrium with the market share variable, when the system is out of balance, and that in the case of the second variable the residual is not statistically significant, which means that the second variable is weakly exogenous and that it does not move to restore the equilibrium with the competitiveness variable. The reversed situation was recorded in the case of three companies. In one case, it both residuals were recorded to be statistically significant, namely in the apparel industry, whereas in the other
Table 3

\begin{tabular}{|c|c|c|c|c|}
\hline \multicolumn{5}{|c|}{ THE RESULTS FOR THE VEC MODEL } \\
\hline \multicolumn{5}{|c|}{ 2007-2018 (T = 12) } \\
Dependent variable: d_v1 \\
(the first difference of profitability) \\
\hline Indicator & Coefficient & Std. error & t-ratio & p-value \\
\hline d_v2_1 & -0.351 & 0.2183 & -1.606 & 0.143 \\
\hline e_1 & -1.249 & 0.348 & -3.587 & $0.006^{* * *}$ \\
\hline d_v1_1 & 0.607 & 0.306 & 1.982 & $0.079^{*}$ \\
\hline F(3,9) & 4.611 & - & P-value(F) & 0.032 \\
\hline \multicolumn{5}{|c|}{ Andjela Ltd: OLS, using the observations for } \\
$2006-2018$ (T = 13) \\
\hline \multicolumn{5}{|c|}{ (the first difference of market share) } \\
\hline Indicator & Coefficient & Std. error & t-ratio & p-value \\
\hline d_v1_1 & -0.048 & 0.436 & -0.109 & 0.915 \\
\hline e_1 & 0.249 & 0.496 & 0.504 & 0.627 \\
\hline d_v2_1 & -0.463 & 0.311 & -1.489 & 0.171 \\
\hline F(3, 9) & 0.988 & - & P-value(F) & 0.441 \\
\hline
\end{tabular}

cases, the residuals for both variables were recorded not be statistically significant.

The summary account of the tested hypotheses and their possible combinations as per the sectors is presented in table 4.

As can be seen from the table 4 , in the largest number of the cases (even in 44), there is no variable influencing the movement of the other one, which means that based on their movement, the movement of the other one is impossible to forecast, as is assumed by the premise on which the Grangercausality test was built. There is a reverse situation in 
THE SUMMARY ACCOUNT OF THE TESTED HYPOTHESES AND THEIR POSSIBLE COMBINATIONS AS PER THE SECTORS

\begin{tabular}{|c|c|c|c|c|c|c|c|}
\hline Sector & $\mathrm{H}_{0,1}$ and $\mathrm{H}_{0,2}$ & $\mathrm{H}_{0,1}$ and $\mathrm{H}_{1,2}$ & $\mathrm{H}_{1,1}$ and $\mathrm{H}_{0,2}$ & $\mathrm{H}_{1,1}$ and $\mathrm{H}_{1,2}$ & $\begin{array}{l}\text { Sum of } \\
\text { comp. }\end{array}$ & Hypoth.* & Hypoth.** \\
\hline The wool industry & 1 & 7 & 4 & - & 12 & -1.224 & 0.508 \\
\hline The carpet industry & 9 & 4 & 3 & 1 & 17 & -2.266 & -1.781 \\
\hline The knitwear industry & 7 & 5 & 1 & - & 13 & -3.124 & -0.904 \\
\hline The footwear idnustry & 9 & 1 & 1 & - & 11 & -2.780 & -2.780 \\
\hline The artificial fiber industry & 11 & 2 & - & - & 13 & -3.678 & -2.569 \\
\hline The apparel industry & 5 & 6 & 3 & 1 & 15 & -1.885 & -0.336 \\
\hline $\begin{array}{l}\text { IT industry of design of } \\
\text { textile }\end{array}$ & 2 & 9 & 1 & 3 & 15 & -1.885 & 2.247 \\
\hline Total & 44 & 34 & 13 & 5 & 96 & -6.321 & -2.033 \\
\hline
\end{tabular}

Note: $\mathrm{H}_{0,1}, \mathrm{H}_{0,1}, \mathrm{H}_{0,2}, \mathrm{H}_{1,2}$ are the null hypotheses and the alternative hypotheses on Granger causality, mentioning that the null ones signify that there is no influence. The * and ** are the hypotheses stipulating that based on competitiveness, market share in the selected developing countries can be forecast or that based on market share, competitiveness in the selected developing countries can be forecast, respectively; the * and ** hypotheses were tested for the confidence level of $95 \%$. In the last two columns, the values of the $Z$ test are given.

the case of five companies, where it was found that there was the Granger cause in both directions. The results as these are in accordance with the general understandings according to which the growth of market shares automatically also implies greater competitiveness, and vice versa, that profitable companies are market leaders. The expectation that based on market share it is possible to forecast a company's competitiveness was recorded in 34 cases, whereas vice versa - that based on the movement of competitiveness market share can be forecast was only found in 13 cases. Although opposing the prevailing understandings of a broader public, the results like these are yet also expected to a certain extent when we bear in mind the characteristics of the economic ambience of these countries.

Namely, a large number of the successful companies operating in these countries are basically foreign companies, which achieve profitability thanks to the transfer of know-how from the parent countries [22], not through market penetration. It is particularly notable in the sectors that require the application of contemporary technology and technical-technological achievements [23]. This should also be added the fact that these companies are more oriented towards taking the profit to their parent states than towards reinvesting it in penetration to the domestic market. So, this fact can to a certain extent explain the situation why in a small number of the cases the movement of market share can be forecast based on profitability. The situation is somewhat different in the sectors of the footwear industry, knitwear industry, the apparel industry, which is also expected since they belong to the consumer goods and service sectors, so they are oriented towards an increase in competitiveness by increasing market share and the expectation that competitiveness also grows through market penetration. It is characteristic of these three countries that the IT sector is in great expansion and that there are a large number of companies in the domestic ownership. It characteristic of this sector that based on the movement of market share it is possible to forecast the movement of competitiveness, but not vice versa, either, which can be justified by the fact that it is profitable to serve the domestic market, and that profitability also grows with the growth of market share. The nonexistence of causality in the Granger sense of competitiveness to market share can be explained by the fact that these companies are exclusively oriented towards exporting IT services, for which reason the movement of the profitability of these companies is exclusively connected with exports, not with the domestic market penetration.

Given the fact that the research study was carried out on a small number of the available data so as to obtain robust assessments, the bootstrap approach was used in the paper. The application of the bootstrap approach is simple and depends on whether the known forms of the distribution function of portfolio return is with an unknown parameter which is present in it $\theta=\theta(F)$ or not [23]. Depending on this, it is possible to apply a parametric or non-parametric bootstrap method. By using the parametric bootstrap method, 10,000 samples were generated, the size of which is equal to the actual sample of the series, separately for each series. More precisely, the observations are simulated as the vector of the random outcome based on the set of the data $\theta$. This is how 10,000 new simulated samples with 14 observations. Then, the same procedure of the application of the Granger causality test was performed for each company and for each time series, as well as with the real data. The summary account of the tested hypotheses and their possible combinations based on the simulations as per the sectors and in total are presented in table 5. 


\begin{tabular}{|l|c|c|c|c|c|c|c|}
\hline \multicolumn{7}{|c|}{ THE SUMMARY ACCOUNT OF THE RESULTS ON THE BOOTSTRAP SIMULATION } \\
\hline \multicolumn{1}{|c|}{ Sector } & $\mathbf{H}_{\mathbf{0 , 1}}$ and $\mathbf{H}_{\mathbf{0 , 2}}$ & $\mathbf{H}_{\mathbf{0 , 1}}$ and $\mathbf{H}_{\mathbf{1 , 2}}$ & $\mathbf{H}_{\mathbf{1 , 1}}$ and $\mathbf{H}_{\mathbf{0}, \mathbf{2}}$ & $\mathbf{H}_{\mathbf{1 , 1}}$ and $\mathbf{H}_{\mathbf{1 , 2}}$ & $\begin{array}{c}\text { Sum of } \\
\text { comp. }\end{array}$ & Hypoth.* & Hypoth.** $^{*}$ \\
\hline The wool industry & 67807 & 43521 & 2589 & 1683 & 115600 & -321.735 & -80.910 \\
\hline The carpet industry & 73691 & 30568 & 30964 & 12281 & 147504 & -166.579 & -168.642 \\
\hline The knitwear industry & 80012 & 34230 & 20303 & 4781 & 139326 & -246.375 & -171.737 \\
\hline The footwear industry & 1358 & 376 & 6389 & 1830 & 9953 & 63.020 & -57.547 \\
\hline The artificial fiber industry & 108.327 & 12824 & 7.128 & 934 & 129.213 & -321.860 & -290.162 \\
\hline The apparel industry & 59.914 & 66.217 & 20.971 & 1.001 & 148.103 & -278.407 & -43.219 \\
\hline IT industry & 21356 & 101378 & 9852 & 14635 & 147221 & -263.782 & 213.391 \\
\hline Total & 412465 & 289114 & 98196 & 37145 & 836920 & -637.376 & -219.910 \\
\hline
\end{tabular}

Note: $\mathrm{H}_{0,1}, \mathrm{H}_{0,1}, \mathrm{H}_{0,2}, \mathrm{H}_{1,2}$ are the null and the alternative hypotheses on Granger causality, mentioning that the null ones signify that there is no influence. The * hypotheses were tested for the confidence level of $95 \%$. In the last two columns, the values of the Z-test are given.

The results based on the simulation do not fully confirm the conclusion drawn based on the analysis of the data in table 4. Namely, the results based on the simulation indicate that it can generally be said that it is impossible to forecast the movement of the market share of these enterprises on the basis of the movement of a series of competitiveness (profit rate) data of the enterprises from within the selected sectors, and vice versa, on the markets of the tested countries.

\section{CONCLUSIONS}

The paper dealt with doing research in the existence of causality in Granger's sense between competitiveness and market share, and vice versa, on emerging markets so as to answer the question whether it is possible to forecast the movement of the market share of an enterprise based on the data about the movement of the profit rate of that enterprise, and vice versa, or not. The research study was carried out on the example of 96 companies from Serbia, Montenegro, and Bosnia and Herzegovina. These countries had been selected as the adequate representatives of emerging markets given the fact that they have a series of common characteristics. Because of the protection of the data, the data of only those enterprises with respect to which the authors obtained consent. On that occasion, the authors were careful to present those data that adequately and truly represent the results of the overall analysis in a sense that the selected representative best reflects the prevailing characteristics and the findings that are true for the majority of the enterprises from within this sector, and also to simultaneously safeguard the relationship between the sectors and to represent the results of the overall analysis through the selected representatives in as a realistic manner as possible.
The results of the research are to a certain extent in compliance with certain individual research studies, the mention of which has already been made in the introductory parts of the paper - although market share and competitiveness seem to be positive on average, this relationship is generally weak. In other words, the research results reveal that the existence of causality in Granger's sense between competitiveness and market share on the selected emerging markets depends on the branch of textile industry. They point at the existence of causality between competitiveness and market share in the apparel sector and the IT sector, or between market share and competitiveness in the carpet industry, mentioning that when speaking about causality in this paper causality is always implied as causality in Granger's sense. Also, the results of the research are indicative of the fact that it cannot generally be said whether it is possible to forecast the movement of the profit based on the movement of market share, and vice versa, on these markets. In other words, in the majority of the examined series no existence of a causal connection between these two data series has been found. The results based on the simulation by the bootstrap method fully confirm the previously presented conclusion.

It is recommended that future researchers should include a larger number of enterprises from the selected countries in analysis, mentioning that it is an almost impossible work to do when the availability of the needed data is taken into consideration.

\section{ACKNOLEDGEMENTS}

This paper is part of the research project financed by the Ministry of Education, Science and Technological Development of the Republic of Serbia.

\section{REFERENCES}

[1] Miletic, S., Istraživanje koje se odnosi na novi proizvod, In: Ekonomika, 2010, 56, 3, 21-32

[2] Schoeffler, S., Buzzell, R.D., Impact of Strategic Planning on Profit Performance, In: Harvard Business Review, 1974, 52, 2, 137-145 
[3] Buzzell, R.D., The PIMS program of strategic research: A retrospective appraisal, In: Journal of Business Research, 2004, 57, May, 478-483

[4] Newton, J.K., Market share: Key to higher profitability?, In: Long Range Planning, 1983, 16, 1, 37-41

[5] Hamermesh, R.G., Anderson, M.J., Strategies for Low Market Share Businesses, In: Harvard Business Review, 1978, 56, 3, 95-102

[6] Chawla, S.K., Khanna, D., Chen, J., Are small business critical success factors same in different countries, In: SIES Journal of Management, 2010, 7, 1, 1-12

[7] Chandler, G.N., Hanks, S.H., Measuring the performance of emerging businesses: A validation study, In: Journal of Business Venturing, 1993, 8, 5, 391-08

[8] Boulding, W., Staelin, R., Environment, Market Share, and Market Power, In: Management Science, 1990, 36, 10, 1160-1177

[9] Jacobson, R., Unobservable Effects and Business Performance, In: Marketing Science, 1990, 9, 74-85

[10] Wensley, R., Explaining Success: The Rule of Ten Percent and the Example of Market Share, In: Business Strategy Review, 1997, 8, 1, 63-70

[11] Schmalensee, R., Do Markets Differ Much?, In: American Economic Review, 1985, 75, June, 341-52

[12] Mueller, D.E., Profits in the Long Run, Cambridge University Press, Cambridge, 1986

[13] Yannopoulos, P., The Market Share Effect: New Insights from Canadian Data, In: The Journal of Global Business Management, 2010, 6, 2, 257-267

[14] Faria, J., Wellington, W., Validating business simulations: does high market share lead to high profitability?, In: Developments in business simulation and experiential learning, 2004, 31, 332-336

[15] Amburgey, T.L., Dacin, T., Kelly, D., Disruptive Selection and Population Segmentation: Interpopulation Competition as a Segregation Process, In: Baum, J.A.C., Singh, J. V., (Eds.), Evolutionary Dynamics of Organizations, Oxford University Press, New York, 1994

[16] Sheth, J.N., Sisodia, R.S., The Rule of Three: Surviving and Thriving in Competitive Markets, The Free Press, New York, 2002

[17] Genchev, E., Effects of market share on the bank's profitability, In: Review of Applied Socio-Economic Research, 2012, 3, 1, 87-95

[18] Etale, L., Bringilarz, P., Ifuruezes, M., Market Share and Profitability Relationship: A Study of the Banking Sector in Nigeria, In: International Journal of Business, Economics and Management, 2016, 3, 8, 103-112

[19] Goddard, J., Tavakoli, M., Wilson, J.O.S., Determinants of profitability in European manufacturing and services: evidence from a dynamic panel model, In: Applied Financial Economics, 2005, 15, 18, 1269-1282

[20] Pattitoni, P., Barbara Petracci, B., Spisni, M., Determinants of profitability in the EU-15 area, In: Applied Financial Economics, 2014, 24, 11, 763-775

[21] Leverty, K.G., Market share, profits and business strategy, In: Management Decision, 2001, 39, 8, 607-617

[22] Radivojevic, N., Sabot-Matic, Z., Mirjancic, B., New Historical bootstrap value at risk model, In: Journal of risk model validation, 2017, 11, 4, 57-75

[23] Simonovic, Z., et al., Some problems of small and medium enterprises in Serbian agricultural, In: Anali Ekonomskog fakutletu u Subotici, 2017, 37, 57-69

Authors:

\section{NIKOLA V. ĆURČIĆ ${ }^{1}$, NIKOLA RADIVOJEVIĆ ${ }^{2}$, ALEKSANDAR GRUBOR ${ }^{3}$,} ZORAN D. SIMONOVIĆ 1

${ }^{1}$ Institute for Agricultural Economics in Belgrade, Volgina no. 15, 11000, Belgrade, Serbia e-mail: zoki@medianis.net

2 Technical college at applied studies, Kosovska no. 8, 34000, Kraguejvac, Serbia e-mail: radivojevic034@gmail.com

${ }^{3}$ University of Novi Sad, Faculty of Economics in Subotica, Segedinski put no. 9-11, 24000, Subotica, Serbia e-mail: agrubor@ef.uns.ac.rs

Corresponding author:

NIKOLA ĆURČIĆ

e-mail: nikolavcurcic@yahoo.com 


\title{
Online customized T-shirt design and evaluation of online websites for customization
}

\author{
DOI: 10.35530/IT.071.04.1674
}

AHMET ÖZBEK

\section{ABSTRACT - REZUMAT}

\section{Online customized T-shirt design and evaluation of online websites for customization}

Customized clothing manufacturing is a clothing manufacturing method realized and performed in collaboration between the manufacturer and the customer. In this manufacturing method, the customer is offered a basic piece of clothing and various options (fabric, model, color, style, accessories, printing on clothing, etc.) so that the customer can modify the clothing and design the most suitable garment. Thanks to this manufacturing method, the customer has the opportunity to purchase the most appropriate personalized clothing while, at the same time, the manufacturer achieves a high profit margin by making a customized product. Customized clothing production is an important method in the industry because it increases both the profit margin of the enterprises and the level of customer satisfaction. Although it is not yet a very common method, it is expected that it will become widespread in the future with technological developments. Within the framework of this study, we focused on online customized T-shirt manufacturing. The study was carried out in three stages. In the first stage, the design options that young consumers prefer and/or need for online customized T-shirt design were determined. In the second stage, websites that perform the manufacturing of customized T-shirt that are available online in Turkey were determined. In the third stage, online T-shirt design options determined in the first stage were presented to the customers by the websites determined during the second stage. According to the assessment, customized T-shirt design websites active in Turkey were found to be adequate in terms of the "design with respect to body sizes" option. In addition, some design options that online personalized T-shirt design websites intend to offer change according to the gender and education of young consumers.

Keywords: product customization, T-shirt, clothing, website, customer

\section{Design personalizat online pentru tricouri și evaluarea site-urilor web pentru personalizare}

Fabricarea de îmbrăcăminte personalizată este o metodă de producție realizată printr-o colaborare între producător și client. În cadrul acestei metode de producție, clientului i se oferă un articol de îmbrăcăminte de bază și diverse opțiuni (material textil, model, culoare, stil, accesorii, imprimeu etc.), astfel încât acesta să îl poată modifica și să creeze combinația dorită. Datorită acestei metode de producție, clientul are posibilitatea de a achiziționa articole de îmbrăcăminte personalizate și, în același timp, producătorul atinge o marjă de profit ridicată realizând un produs personalizat. Producția de îmbrăcăminte personalizată este o metodă importantă în industrie, deoarece crește atât marja de profit a întreprinderilor, cât și nivelul de satisfacție a clienților. Deși nu este încă o metodă uzuală, se așteaptă ca în viitor să fie aplicată odată cu evoluția tehnologică. În cadrul acestui studiu, ne-am concentrat pe fabricare tricourilor personalizate. Studiul a fost realizat în trei etape. În prima etapă, au fost determinate opțiunile de design pe care le preferă tinerii consumatori și/sau necesitatea unui design online personalizat pentru tricouri. În a doua etapă, au fost identificate site-urile web care oferă posibilitatea personalizării tricourilor, disponibile online în Turcia. În cea de-a treia etapă, opțiunile de design online pentru tricouri, identificate în prima etapă, au fost prezentate clienților prin site-urile web identificate în cea de-a doua etapă. Conform evaluării, s-a constatat că site-urile web de design personalizate pentru tricouri, active în Turcia, sunt adecvate în ceea ce privește opțiunea „design care respectă dimensiunile corpului”. În plus, unele opțiuni de design pe care site-urile online de design personalizat pentru tricouri intenționează să le ofere se pot modifică în funcție de sex și de educația tinerilor consumatori.

Cuvinte-cheie: personalizare, tricou, îmbrăcăminte, site web, client

\section{INTRODUCTION}

In the past, consumers had to choose from existing products in spite of a lack of variety. As the number of producers in the following years increased the product range increased, and more variety was offered [1]. In addition, the increase in production and employment brought about socio-economic development and thus the living standards and quality of life of consumers began to improve [2]. Thus, consumers started to expect more from the producers. This has reached its most advanced stage in sectors such as clothing and footwear [3]. Not only are consumers demanding fashionable and innovative clothing at competitive prices, but they are also constantly changing their demands because of the desire for customized clothing and up to the minute fashion. As a result, clothing manufacturers are no longer able to meet the needs of different consumers with a single choice in clothing [3-4]. 
In addition to the changing demands of consumers, intense international competition in the sector has started to decrease the production levels and profit margins of clothing companies [5]. Business establishments are focused on meeting the needs of consumers (who are extremely knowledgeable, demanding, and self-absorbed), selling products to consumers repeatedly, and largely preserving their intention to buy products from them again. Therefore, consumers have started to find solutions to their problems such as time problems, discomfort, long queues, product problems, high prices, order problems, and inadequate options [6-8]. As a solution to these problems, they have concluded that the transition from productoriented production to customer-oriented production could be one of the desired solutions [9].

With the advent of computer-aided design (CAD), computer-aided manufacturing (CAM), 3D technologies, body scanning systems, and internet technologies, and the customer-oriented use of the clothing industry, customized manufacturing has started to develop [4, 10-13]. In customized manufacturing, where customers can change the production line of the company to produce products to their own design and requirements, production is carried out only according to the wishes of the customers, and the design is carried out jointly with the customer, including modular product designs, flexible processes, and supply chain integration with customized products at the determined place and time and featuring a technology-assisted manufacturing method [11, 13, 15].

Customized manufacturing provides significant advantages to both the business and the consumer. For the business, the advantages are advanced customer knowledge, a high profit margin, high customer satisfaction, the ability to reach more customers at a low cost, a long-term relationship with the customer, flexible production, low and/or non-stock production, new design garment production, reduction in waste, rapid flow of cash, no discount pricing, coping with market uncertainties, quick response to customer demands, and higher levels of customer loyalty. In terms of consumers, personalized production offers a variety of advantages including a unique shopping experience, flexibility, personalized clothing, a shorter delivery time, high satisfaction, and access to unique clothing at affordable prices [3, 7, 12, 14, 17-19]. Thanks to these advantages of customized manufacturing, the mass (batch) production of clothes is reduced, and the cost-effective production of highquality clothing for consumers is increased [16].

Customized manufacturing has some differences from traditional mass production. Customized manufacturing consists of two stages. The first stage is where the enterprise establishes a flexible customization system that meets the needs of the overall consumer profile. The second stage is where consumers personalize their common design products using the options offered to them [4, 16, 20].

Clothing has significant potential for customized manufacturing because of its versatility, modular characteristics, and the nature of self-expression
[21]. Customized manufacturing in the clothing industry consisted, at first, of phases such as measuring the customer's body size by an employee and then entering the size into the computer as well as the customer's preferred clothing characteristics; then the fabric was determined according to the specified size, the fabric was cut into pieces and then assembled into a garment, and finally, the garment was presented to the customer [12]. However, the development of body scanners, 3D virtual clothing simulation, and the Internet and other technologies has eliminated many of the above steps. In the new situation, the customer can produce his or her own personalized garment by using the internet and other technologies without the need to go to the business establishment for measurements and choices [5, 22]. In this production method, enterprises have the opportunity to meet the current customer requirements and recapture the efficiency advantages they had previously provided in mass production [6].

Customized manufacturing was realized in the early days of the clothing sector by offering the consumer some very simple options (such as printing on the garment, printing elements such as shapes) [11]. With the development of technology, customized manufacturing can now offer unlimited choice to the consumer (choosing the most appropriate model from the basic garment samples and then choosing the fabric, model, color, style, accessories, etc. on the basic garment the customer has chosen), and this industry continues to develop [23].

The manufacturing of customized clothing started commercially in the 1990s with related implementations by clothing business enterprises such as Levi Strauss (Second Skin Swimwear and Custom Foot), Nike (Nikeid and Lands-End) and Adidas (miadidas) [10]. An increasing number of apparel manufacturers (e.g. Polo Jeans) and retailers of different sizes (e.g. Lands' End) and some fully online business enterprises (e.g. Threadless, Zazzle) have solidified their advantage as precursors and adopted the production of customized garments [5]. Furthermore, more and more consumers are demanding personalized clothing every day [2]. So much so that clothing retailer Land's End has found that online customized manufacturing has a strong and positive impact on consumer loyalty [24].

In customized manufacturing, it is important that information transfer between the enterprise and the customer takes place instantly and efficiently and that customers can view the final prototype online [3, 10]. For this reason, there is a need for advanced production technologies, flexible management techniques, and especially information technologies for customized manufacturing [25]. The internet is the medium for technology that can best provide this relationship today [17]. For this reason, fashion products have begun to be customized widely with computer technology via the internet [25]. For example, Khan et al. [26] developed a web-based portal for obese consumers to purchase customized clothing online with simple, easy steps. This portal allows the 
customer to design clothes according to their personal body size, create their own style, and choose the fabric. Nike provides an online platform for customers to order customized products. Through this platform, customers can select products and print their names on them. In addition, customers can make some customizations using the options on the semi-finished standard product [11]. As seen in the examples, online customized manufacturing has begun to turn into a commercial advantage [24].

As a result, although online customized clothing production is new, its use in daily life increases with developments in technology. Because of this feature, it is foreseen that the usage of customization and its importance in the clothing sector will continue to increase. The aim of this study is to determine the customers' choices and needs oriented options and to evaluate the customized T-shirt manufacturing websites available currently in Turkey in terms of their ability to provide the determined choices within the scope of this research.

\section{MATERIAL AND METHOD}

The implementation section of the research consists of three stages. In the first stage, the design options that consumers prefer and/or need for online customized T-shirt design were determined. In the second stage, customized T-shirt design websites available online in Turkey were determined. In the third and final stage, the providing of consumers with options outlined within the scope of the research in the context of websites that perform online customized T-shirt production situation in Turkey was evaluated. The flow diagram of the research study is given in figure 1 .

Stage 1: Identifying and determining online customized T-shirt design options

In this study, qualitative-quantitative research methods were used together. In this context, both questionnaire and interview techniques were used during the data collection phase of the study [27]. Due to the scope of the research regarding internet use and the proportion of young people in Turkey who shop online, it was designated as the universe of the study. According to Turkey Statistical Institute (TSI) the population of young people in Turkey is 12,983,097 [28]. YÖK (Higher Education Council) states that 59.62\% of young people in Turkey $(7,740,502)$ are university

students [29]. Thus, university students were chosen as the sample for the study. In addition, the T-shirt was chosen as the item of customized online clothing because of its simplicity of manufacturing compared to other garments and its high rate of purchase by young people.

The survey method was used to determine the choices that young consumers need and/or prefer for designing online customized T-shirts. For the design of the related questionnaire, firstly the literature was examined, and then a face-to-face interview was conducted with 25 students from Sinop University. The questionnaire, which was composed of data obtained from these two sources, consisted of two parts. In the first part, there are five multiple-choice questions about the socio-economic characteristics of the participants. In the second part, there are 14 options regarding the elements that young consumers need and/or prefer for an online customized T-shirt design which consisted of a five-point Likerttype response set: $1=$ not important at all, $2=$ less important, 3= reasonably important, $4=$ mportant, $5=$ very important.

The questionnaire was applied to a group of 60 people and tested. The data obtained as a result of the application was subjected to reliability analysis and Cronbach's alpha value $(\alpha)$ was found to be 0.853 . Since this value shows that the questionnaire can provide the desired data for the research [30], the survey was published on the website www.surveey.com between 05.12.2017 and 30.12.2017 in order to reach all university students. 847 university students completed the questionnaire, but only $66.8 \%$ (566) of them were considered valid due to deficiencies in the questionnaires completed. Survey data were evaluated with the IBM SPSS Statistics Data Editor program, and the results are given below.

In terms of gender distribution, $61.6 \%$ (349) of the students were women, $33.3 \%$ (189) were men, and $4.9 \%$ (28) did not answer this question. There were 566 participants in total. Distribution of participants according to age groups was 17, 18, 19, 20, 21, 22, and 23 and over. The largest percentage of women was in the 19 age group, $27.0 \%$ (96), and the largest percentage of men were in the 21 age group, $20.0 \%$ (39).

The distribution of the educational status of the participants is given in table 1. According to the table, more than $90 \%$ of the partici-

STAGE 1: Identifying consumers' needs and/or preferred design options for online customized T-shirt design

STAGE 2: Determining available online customized T-shirt design websites in Turkey

STAGE 3: Evaluating the options determined in Stage 1 according to the presence of the websites determined in Stage 2 in terms of offert to consumers

Fig. 1. Flow Diagram of the research study pants had an associate's degree and an undergraduate education. In addition, $49.9 \%$ (174) of the participants were women with an undergraduate education, and $49.2 \%$ (93) were men with an associate's degree. The distribution of the participants according to their monthly income is given in table 2. According to the 


\begin{tabular}{|l|c|c|c|c|c|c|}
\hline \multicolumn{7}{|c|}{ DISTRIBUTION OF PARTICIPANTS ACCORDING TO EDUCATION LEVEL } \\
\hline \multirow{2}{*}{ Education status } & \multicolumn{2}{|c|}{ Female } & \multicolumn{2}{c|}{ Male } & \multicolumn{2}{c|}{ Total } \\
\cline { 2 - 7 } & Number & Frequency (\%) & Number & Frequency (\%) & Number & Frequency (\%) \\
\hline Associates Students & 162 & 46.4 & 93 & 49.2 & 255 & 47.4 \\
\hline Bachelor's Students & 174 & 49.9 & 88 & 46.6 & 262 & 48.7 \\
\hline Postgraduate Students & 13 & 3.7 & 8 & 4.2 & 21 & 3.9 \\
\hline Total & 349 & 100 & 189 & 100 & 538 & 100 \\
\hline *UAN & \multicolumn{7}{|c|}{28} & & \\
\hline
\end{tabular}

Note: *Number of participants who did not answer this question (UAN)

\begin{tabular}{|l|c|c|c|c|c|c|}
\hline \multicolumn{5}{|c|}{ DISTRIBUTION OF PARTICIPANTS ACCORDING TO MONTHLY REVENUES } \\
\hline \multirow{2}{*}{ Income } & \multicolumn{2}{|c|}{ Female } & \multicolumn{2}{c|}{ Male } & \multicolumn{2}{c|}{ Total } \\
\cline { 2 - 8 } & Number & Frequency (\%) & Number & Frequency (\%) & Number & Frequency (\%) \\
\hline 0-250 TL & 56 & 15.9 & 15 & 7.7 & 71 & 12.9 \\
\hline $251-500 \mathrm{TL}$ & 115 & 32.6 & 49 & 25.1 & 164 & 29.9 \\
\hline $501-750 \mathrm{TL}$ & 74 & 21 & 36 & 18.5 & 110 & 20.0 \\
\hline 751-1000 TL & 27 & 7.6 & 21 & 10.8 & 48 & 8.7 \\
\hline $1001-1250 \mathrm{TL}$ & 29 & 8.2 & 15 & 7.7 & 44 & 8.0 \\
\hline $1251-1500 \mathrm{TL}$ & 17 & 4.8 & 24 & 12.3 & 41 & 7.4 \\
\hline 1501 TL and over & 35 & 9.9 & 35 & 17.9 & 70 & 12.7 \\
\hline Total & 353 & 100 & 195 & 100 & 548 & 100 \\
\hline UAN & \multicolumn{7}{|c|}{} & & 18 & & \\
\hline
\end{tabular}

table, $29.9 \%$ (164) of the participants had a monthly income of $251-500 \mathrm{TL}$. The proportion of the participants with income of TL 1001 or more is approximately $28.2 \%$. In addition, $32.6 \%$ (115) of the female participants and $25.1 \%$ (49) of the male participants had a monthly income of 251-500 TL.

Table 3 shows the data on the participants' desire to find suitable T-shirts, purchase clothes online, and design customized T-shirts online. According to the table, $40.0 \%$ (142) of the female participants and
$46.6 \%(90)$ of the male participants could not find an appropriate T-shirt. $73.5 \%$ (261) of the female participants and $63.7 \%$ (123) of the male participants buy clothes online. Again, according to the data, women buy more clothes online than men. In addition, $83.1 \%$ (294) of the female participants and $87.9 \%$ (145) of the male participants had the desire to design online customized T-shirts. These data were perceived as need for online customized T-shirts manufacturing in Turkey.

DISTRIBUTIONS ACCORDING TO THE DESIRE OF PARTICIPANTS TO FIND T-SHIRT SUITABLE FOR THEIR TASTE, TO PURCHASE ONLINE CLOTHING, AND TO DESIGN A CUSTOMIZED T-SHIRT ONLINE

\begin{tabular}{|c|c|c|c|c|c|c|c|}
\hline \multirow{2}{*}{\multicolumn{2}{|c|}{ Answers }} & \multicolumn{2}{|c|}{$\begin{array}{c}\text { Status of the participants } \\
\text { finding T-shirt duitable } \\
\text { to their desire }\end{array}$} & \multicolumn{2}{|c|}{$\begin{array}{c}\text { Status of the participants } \\
\text { wishing to purchase T-shirt } \\
\text { online }\end{array}$} & \multicolumn{2}{|c|}{$\begin{array}{c}\text { Status of the participants } \\
\text { wishing to design T-shirt } \\
\text { online }\end{array}$} \\
\hline & & Number & Frequency (\%) & Number & Frequency (\%) & Number & Frequency (\%) \\
\hline \multirow[t]{2}{*}{ Female } & Yes & 213 & 60 & 261 & 73.5 & 294 & 83.1 \\
\hline & No & 142 & 40 & 94 & 26.5 & 60 & 16.9 \\
\hline \multirow[t]{2}{*}{ Male } & Yes & 103 & 53.4 & 123 & 63.7 & 145 & 87.9 \\
\hline & No & 90 & 46.6 & 70 & 36.3 & 20 & 12.1 \\
\hline \multirow[t]{2}{*}{ Total } & Yes & 316 & 57.6 & 384 & 70.0 & 439 & 84.5 \\
\hline & No & 232 & 42.3 & 164 & 29.9 & 80 & 15.4 \\
\hline \multicolumn{2}{|c|}{ Answered number } & \multicolumn{2}{|r|}{548} & \multicolumn{2}{|r|}{548} & \multicolumn{2}{|c|}{519} \\
\hline \multicolumn{2}{|l|}{ UAN } & \multicolumn{2}{|r|}{18} & \multicolumn{2}{|r|}{18} & \multicolumn{2}{|r|}{47} \\
\hline
\end{tabular}


DISTRIBUTION OF PARTICIPANTS ACCORDING TO THE NUMBER OF T-SHIRTS THAT THEY WANT TO BUY BY DESIGNING ONLINE IN ONE YEAR

\begin{tabular}{|l|c|c|c|c|c|c|}
\hline \multirow{2}{*}{ T-shirts orders } & \multicolumn{2}{|c|}{ Female } & \multicolumn{2}{c|}{ Male } & \multicolumn{2}{c|}{ Total } \\
\cline { 2 - 7 } & Number & Frequency (\%) & Number & Frequency (\%) & Number & Frequency (\%) \\
\hline 1-2 Pieces & 34 & 11.5 & 23 & 15.8 & 57 & 12.9 \\
\hline 3-4 Pieces & 56 & 18.9 & 21 & 14.4 & 77 & 17.4 \\
\hline 5-6 Pieces & 71 & 24.0 & 35 & 24.0 & 106 & 23.9 \\
\hline 7-8 Pieces & 37 & 12.5 & 12 & 8.2 & 49 & 11.0 \\
\hline 9 and Over Pieces & 98 & 33.1 & 55 & 37.7 & 153 & 34.6 \\
\hline Total & 296 & 100 & 146 & 100 & 442 & 100 \\
\hline UAN & \multicolumn{7}{|l|}{124} & & \\
\hline
\end{tabular}

Table 4 shows the number of T-shirts that the participants would like to design and purchase online in one year. According to the table, $34.6 \%$ (153) of the participants were willing to purchase and design nine or more online customized T-shirts per year. Also, according to gender; $33.1 \%$ (98) of the female participants and $37.7 \%$ (153) of the male participants had the desire to design and purchase nine or more customized online T-shirts in one year.

Factor analysis was performed with the IBM SPSS Statistics Data Editor program to respond to consumers' needs and/or preferred options for online customized T-shirt design. In factor analysis, factor loads of 0.500 and above were considered to be quite good, and questions with factor loads below this value were excluded from the analysis [30]. According to the results of the analysis, the factor load of the option to use more than one color in a T-shirt was 0.441 , and the factor load of the various sewing thread options was 0.492 ; the factor analysis was performed twice. Table 5 shows the results of the factor analysis and explains the total variance. While the total variance explained in the first case was $58.251 \%$, when these options were excluded from

Table 5

\begin{tabular}{|l|c|}
\hline \multicolumn{2}{|c|}{ FACTOR ANALYSIS RESULTS } \\
\hline \multicolumn{2}{|c|}{ Options } \\
(Declared total variance 63.603\%) & $\begin{array}{c}\text { Factor } \\
\text { loadings }\end{array}$ \\
\hline Wide variety of fabrics & 0.846 \\
\hline Wide range of fabric colors & 0.719 \\
\hline Wide range of collar types & 0.601 \\
\hline Design according to body sizes & 0.689 \\
\hline Wide variety of T-shirt cuts & 0.759 \\
\hline Determining the length of the shirt & 0.799 \\
\hline Determining the sleeve length of the T-shirt & 0.749 \\
\hline Printing on the desired area of the T-shirt & 0.761 \\
\hline $\begin{array}{l}\text { Identifying auxiliary materials such as } \\
\text { button, zipper, etc. }\end{array}$ & 0.707 \\
\hline Determination of pocket size and location & 0.709 \\
\hline Printing photos on a T-shirt & 0.709 \\
\hline Original design & 0.550 \\
\hline
\end{tabular}

the analysis, the total variance explained was $63.603 \%$ and the factor loadings increased to 0.500 as shown in table 5 .

In addition, according to the factor analysis, the KMO and Bartlett's Test value was obtained as 0.875 , and the analysis was continued because this value was higher than 0.500 . The reliability analysis was then performed, and the options derived from the factor analysis results were not included in the analysis. Accordingly, Cronbach's alpha, the value of the answers for the choices was found to be 0.875 . Since this value was between $0.80 \leq \alpha<1.00$, it was found that the questionnaire for options was highly reliable [30].

Table 6 presents the average and standard deviation values of the participants' responses to the items required by consumers for online customized T-shirt design.

The arithmetic means and standard deviations in Table 6 were calculated regarding the answers

Table 6

AVERAGE AND STANDARD DEVIATION VALUES OF ONLINE PERSONALIZED T-SHIRT DESIGN OPTIONS

\begin{tabular}{|l|c|c|}
\hline \multicolumn{1}{|c|}{ Options } & Mean & $\begin{array}{c}\text { Std. } \\
\text { Deviation }\end{array}$ \\
\hline Design according to body sizes & 4.43 & 0.639 \\
\hline Original design & 4.30 & 0.662 \\
\hline Determining the length of the shirt & 4.29 & 0.682 \\
\hline Wide range of collar types & 4.27 & 0.652 \\
\hline Wide range of fabric colors & 4.26 & 0.689 \\
\hline Wide variety of T-shirt cuts & 4.20 & 0.743 \\
\hline $\begin{array}{l}\text { Determining the sleeve length of } \\
\text { the T-shirt }\end{array}$ & 4.16 & 0.727 \\
\hline Wide variety of fabrics & 4.14 & 0.694 \\
\hline $\begin{array}{l}\text { Identifying auxiliary materials such } \\
\text { as button, zipper, etc }\end{array}$ & 4.09 & 0.761 \\
\hline $\begin{array}{l}\text { Printing on the desired area of the } \\
\text { T-shirt }\end{array}$ & 4.04 & 0.773 \\
\hline $\begin{array}{l}\text { Determination of pocket size and } \\
\text { location }\end{array}$ & 3.83 & 0.830 \\
\hline Printing photos on a T-shirt & 3.76 & 0.886 \\
\hline
\end{tabular}


obtained from the 566 participants. It is at the top of the table because the standard deviation was small and the estimation was definite. Arithmetic means are given in order of magnitude. Thus, while the importance given to the first estimation is most evident, it can be seen that, as the list goes down, the importance given to expressions decreases.

Of the 566 participants, $447(72.6 \%)$ responded to the design according to size statement. The average of the answers given to this statement was 4.43 , and the standard deviation was 0.639 . These data show that the statement for the design according to body sizes was perceived as very important by the participants.

Of the 566 participants, 446 (72.4\%) answered the original design question. The average of the responses given to expression was 4.30 and the standard deviation was 0.662 . These data show that original design expression was perceived as very important by the participants.

Of the total of 566 participants, 444 (72.1\%) answered the about determining the length of the T-shirt. The average of the answers given to the statement was 4.29 and the standard deviation was 0.682 . These data indicate that the T-shirt length determination question was perceived as very important by the participants.

Of the 566 participants, 447 (72.6\%) answered the photograph print question. The average of the answers given to the question was 3.76 and the standard deviation was 0.886 . This shows that the expression of printing photos on a T-shirt was perceived by the participants as moderately important. Of the 566 participants, $443(71.9 \%)$ answered the question about determining the size and location of the pocket. The average of the answers given to the question was 3.83 and the standard deviation was 0.830 . This shows that the expression of the measure and location of the pocket was perceived by the participants as moderately important.

In addition, age, gender, education, and income status of young consumers and their relationship to design options that online personalized T-shirt design websites are intended to provide were investigated. For this purpose, four hypotheses were developed:

$\mathbf{H}_{1}$ : There is a relationship between the age of young consumers and the design options that online personalized T-shirt design websites offer.

$\mathbf{H}_{2}$ : There is a relationship between the gender of young consumers and the design options that online personalized T-shirt design websites offer.

$\mathbf{H}_{3}$ : There is a relationship between the education of young consumers and the design options that online personalized T-shirt design websites are required to offer.

$\mathbf{H}_{\mathbf{4}}$ : There is a relationship between the income of young consumers and the design options that online personalized T-shirt design websites offer.

The results of the correlation analysis to determine the relationships between the participants' age, gender, education, and income status, and the design options that online customized T-shirt design websites are required to present are shown in table 7 .

According to table $7, \mathrm{H}_{1}$ and $\mathrm{H}_{4}$ hypotheses were rejected as there was no relationship between the age and income of young consumers and the design options that online personalized T-shirt design websites intended to offer. This shows that the design

\begin{tabular}{|l|c|c|c|c|c|c|c|c|}
\hline \multicolumn{7}{|c|}{ CORRELATION ANALYSIS RESULTS } \\
\hline \multirow{2}{*}{ Options } & \multicolumn{2}{|c|}{ Age } & \multicolumn{2}{c|}{ Gender } & \multicolumn{2}{c|}{ Education } & \multicolumn{2}{c|}{ Income } \\
\cline { 2 - 10 } & $\begin{array}{c}\text { Pearson } \\
\text { correlation }\end{array}$ & Sig. & $\begin{array}{c}\text { Pearson } \\
\text { correlation }\end{array}$ & Sig. & $\begin{array}{c}\text { Pearson } \\
\text { correlation }\end{array}$ & Sig. & $\begin{array}{c}\text { Pearson } \\
\text { correlation }\end{array}$ & Sig. \\
\hline Wide variety of fabrics & -0.079 & 0.105 & $-0.131^{* *}$ & 0.007 & -0.046 & 0.340 & 0.056 & 0.252 \\
\hline Wide range of fabric colors & 0.005 & 0.922 & $-0.146^{* *}$ & 0.003 & -0.045 & 0.360 & 0.005 & 0.922 \\
\hline Wide range of collar types & 0.072 & 0.139 & -0.039 & 0.423 & $-0.100^{*}$ & 0.040 & 0.024 & 0.618 \\
\hline Design according to body sizes & 0.072 & 0.142 & -0.073 & 0.133 & -0.040 & 0.411 & -0.046 & 0.349 \\
\hline Wide variety of T-shirt cuts & 0.042 & 0.390 & -0.057 & 0.244 & $-0.134^{* *}$ & 0.006 & 0.024 & 0.629 \\
\hline Determining the length of the T-shirt & -0.049 & 0.319 & $-0.096^{*}$ & 0.049 & $-0.136^{* *}$ & 0.005 & 0.077 & 0.116 \\
\hline $\begin{array}{l}\text { Determining the sleeve length of the } \\
\text { T-shirt }\end{array}$ & -0.070 & 0.153 & -0.040 & 0.417 & $-0.129^{* *}$ & 0.008 & 0.043 & 0.378 \\
\hline $\begin{array}{l}\text { Printing on the desired area of the } \\
\text { T-shirt }\end{array}$ & 0.031 & 0.527 & -0.020 & 0.686 & -0.019 & 0.696 & -0.034 & 0.483 \\
\hline $\begin{array}{l}\text { Identifying auxiliary materials such as } \\
\text { button, zipper, etc. }\end{array}$ & 0.041 & 0.398 & $-0.114^{*}$ & 0.020 & -0.039 & 0.426 & 0.001 & 0.989 \\
\hline $\begin{array}{l}\text { Determination of pocket size and } \\
\text { location }\end{array}$ & 0.036 & 0.463 & $-0.099^{*}$ & 0.044 & -0.095 & 0.052 & 0.073 & 0.137 \\
\hline Printing photos on a T-shirt & -0.053 & 0.280 & -0.005 & 0.923 & $0.109^{*}$ & 0.025 & -0.076 & 0.120 \\
\hline Original design & -0.023 & 0.633 & $-0.127^{* *}$ & 0.009 & -0.012 & 0.811 & -0.031 & 0.521 \\
\hline
\end{tabular}

Note: ${ }^{* *}$ Correlation is significant at the 0.01 level (2-tailed) and * Correlation is significant at the 0.05 level (2-tailed). 
options that online personalized T-shirt design websites intend to offer do not change according to these factors. However, the $\mathrm{H}_{2}$ and $\mathrm{H}_{3}$ hypotheses were accepted as it was determined that there was a relationship between the gender and education of young consumers and the design options that online personalized T-shirt design websites intended to offer. This suggests that with the change in gender and educational level of young consumers, the design options that online personalized T-shirt design websites are required to offer do change. The identified relationship is a significant and negative relationship between gender and education and the design options that consumers are required to offer online personalized T-shirt design websites.

Stage 2: Determining the online customized T-shirt design websites available in Turkey

In order to identify online T-shirt design websites that are active in Turkey, personalized search was made using the Google search engine. As a result of the search, it was seen that relevant websites generally originated from abroad. In Turkey, only eight online T-shirt design websites were identified. All of these websites were included in the research. However, the names of the websites were hidden by giving a code to each website because of the legal difficulties and time issues that would arise from attempting to obtain permission for research from the related websites. Codes given to websites were formed by the following letters: A, B, C, D, E, F, G and $\mathrm{H}$.

Stage 3: Evaluation and assessment of online customized T-shirt design websites

For the websites that already offer online customized T-shirts in Turkey, the condition of providing consumers with options specified in the first stage was evaluated in this section. In order to carry out the evaluation, a team of three experts consisting of an e-commerce expert, a fashion designer, and a garment manufacturing expert was formed. The team visited the designated online customized T-shirt production websites together and evaluated their availability to customers. The evaluation results are given in table 8 . Online personalized T-shirt production sites evaluated according to table 8 were found to be sufficient in terms of size design, which is the most preferred option for young consumers. Also, in terms of the option of printing photos on a T-shirt, C, D and G websites were found to be sufficient in terms of the option to print the desired region of the T-shirt; $\mathrm{D}$ and $G$ websites in terms were found to be sufficient in terms of a wide variety of T-shirt cut options; the F website was found to be sufficient in offering a wide range of fabric color options; and $A, B, F$, and $E$ sites were found to be sufficient. However, online customized T-shirt manufacturing websites were found to be insufficient and inadequate in terms of offering a wide variety of fabric, collar types, T-shirt length determination, T-shirt sleeve length determination, determination of auxiliary materials such as buttons, zippers etc., determination of the size and location of the pocket, and to offering original design options.

\section{DISCUSSION}

The production of online customized clothing has been a topic that has been studied since the 1990s. The first examples of this production were implementations where customers chose the product, the customer's name was printed on the selected product through an online platform performed by Nike and some other businesses. These were followed by implementations where customers could make some personalizations and customizations using limited options on a semi-finished standard garment. In the course of time, applications started to emerge, even though at a simple level, according to the customer's body sizes. An example of these applications is Khan et al. [26], a portal that allows obese consumers to

EVALUATION AND ASSESSMENT OF ONLINE CUSTOMIZED T-SHIRT DESIGN WEBSITES AVAILABLE IN TURKEY

\begin{tabular}{|l|c|c|c|c|c|c|c|c|}
\hline \multicolumn{1}{|c|}{ Options } & \multicolumn{5}{c|}{ Web sites } \\
\cline { 2 - 9 } & A & B & C & D & E & F & G & H \\
\hline Wide variety of fabrics & - & - & - & - & - & - & - & - \\
\hline Wide range of fabric colors & + & + & - & - & + & + & - & - \\
\hline Wide range of collar types & - & - & - & - & - & - & - & - \\
\hline Design according to body sizes & + & + & + & + & + & + & + & + \\
\hline Wide variety of T-shirt cuts & - & - & - & - & - & + & - & - \\
\hline Determining the length of the shirt & - & - & - & - & - & - & - & - \\
\hline Determining the sleeve length of the T-shirt & - & - & - & - & - & - & - & - \\
\hline Printing on the desired area of the T-shirt & - & - & - & + & - & - & + & - \\
\hline Identifying auxiliary materials such as button, zipper, etc. & - & - & - & - & - & - & - & - \\
\hline Determination of pocket size and location & - & - & - & - & - & - & - & - \\
\hline Printing photos on a T-shirt & - & - & + & + & - & - & + & - \\
\hline Original design & - & - & - & - & - & - & - & - \\
\hline
\end{tabular}


design customized clothing online. However, there is still a need for studies in which the design options that consumers need and/or prefer are identified and presented to the consumer.

This study focused solely on the online design of T-shirts, focusing on whether the consumer was provided with desirable and/or preferred options for an online customized T-shirt design and evaluating the online customized T-shirt design sites with the aim of contributing to the design and development of online customized clothing design websites, thus differing from other studies.

In general, the results of the research show that today it is important for both the customer and the manufacturer to avoid loss of time by going to the manufacturer's shop to buy personal clothing. However, the customer needs to be able to enter his/her own body size on the website in order to purchase personal garments without going to the manufacturer's shop. However, this situation can cause problems due to incorrect measurement entries. One of the short-term solutions to the wrong measurement input problem is visual and easy-to-understand tools that customers can use to determine their own body size which can be developed and placed to personal design web sites. In the long run, the customers' avatars can be created in electronic medium according to their own dimensions. Thus, the customer will be able to design clothes for themselves using their avatars on the online personalized website and will be able to buy the garment by seeing the final form of the garment on them. It is foreseen that such developments will further increase the demand for online personal garment production.

\section{CONCLUSIONS}

As a consequence of the conducted study, of young consumers in Turkey, approximately $70 \%$ of them buy their clothes online, approximately $45 \%$ of them are unable to find T-shirts suitable for their tastes, $85 \%$ of them are willing to design online customized T-shirts, and $34.6 \%$ of them are willing to buy nine or more online customized designed T-shirts each year. Young consumers prefer online customized T-shirt for the design and/or requirements for the design options; this was determined by gathering data through surveys of university students in Turkey. From the analysis of the data, the first three rows of the most preferred/needed design options of the young consumers for online T-shirt design were designed according to the size of the body, original design, and the determination of the length of the T-shirt. On the other hand, it was determined that the design options that young contractors prefer/need less in an online T-shirt design include printing photos on T-shirts, determining the size and location of the pocket, and printing on the desired area of the T-shirt.

Eight customized T-shirt design websites which continue to operate in Turkey were evaluated with respect to their state and condition of offering design options to consumers and customers determined within the scope of the study. As a result of the evaluation, it was determined that the related web sites were found sufficient in terms of the design option according to the body size measurements while the related web sites had partial competence in terms of other options.

According to the results of correlation analysis; the design options that online personalized T-shirt design websites intend to offer do not change according to the age and income of young consumers. However, some design options have a relationship with the gender and education of young consumers. The identified relationship is significant and negative. For gender, the relationship exists with the wide variety of fabric, wide range of fabric colors, determining the length of the shirt, identifying auxiliary materials, determination of pocket size and location, and original design. For income, the relationship exists with wide variety of T-shirt cuts, determining the length of the T-shirt, determining the sleeve length of the T-shirt and printing photos on a T-shirt.

\section{ACKNOWLEDGMENTS}

I would like to convey my thanks and gratitude to Assoc. Prof. Dr. Aytaç Yildiz, Dr. Asım Topakli and Teaching Assistant Naile Erdoğan who had contributed to this study.

\section{REFERENCES}

[1] Satam, D., Liu, Y., Lee, H.J., Intelligent design systems for apparel mass customization, In: The Journal of The Textile Institute, 2011, 102, 4, 353-365

[2] Zhao, Y., Manufacturing personalization models based on industrial big data, In: Journal of Discrete Mathematical Sciences and Cryptography, 2018, 21, 6, 1287-1292

[3] Matthews, D., Rothenberg, L., Gopalakrishnan, S., The impact of mass customization on fashion-innovative students: an assessment of need for uniqueness, self-identity, and perceived performance risk, In: International Journal of Fashion Design, Technology and Education, 2019, 1-8

[4] De Silva, R.K.J., Rupasinghe, T.D., Apeagyei, P., A collaborative apparel new product development process model using virtual reality and augmented reality technologies as enablers, In: International Journal of Fashion Design, Technology and Education, 2019, 12, 1, 1-11

[5] Liang, Y., Liu, C., Comparison of consumers' acceptance of online apparel mass customization across web and mobile channels, In: Journal of Global Fashion Marketing, 2019, 10, 3, 228-245

[6] Piller, F.T., Moeslein, K., Stotko, C.M., Does mass customization pay? An economic approach to evaluate customer integration, In: Production planning \& control, 2004, 15, 4, 435-444 
[7] Wu, J., Co-design communities online: turning public creativity into wearable and sellable fashions, In: Fashion Practice, 2010, 2, 1, 85-104

[8] Li, P., Yu, C., Wu, C., Customer-centered co-design modularization: the skirt design on mobile application, In: The Journal of The Textile Institute, 2019, 1-7

[9] Bulgun, E.Y., Kut, A., An Internet Oriented Custom-Fit Production Approach for Apparel Industry, In: Journal of Organizational Computing and Electronic Commerce, 2005, 15, 4, 285-293

[10] Lee, H.H., Damhorst, M.L., Campbell, J.R., Loker, S., Parsons, J.L., Consumer satisfaction with a mass customized Internet apparel shopping site, In: International Journal of Consumer Studies, 2011, 35, 3, 316-329

[11] Nayak, R., Padhye, R., Wang, L., Chatterjee, K., Gupta, S., The role of mass customisation in the apparel industry, In: International Journal of Fashion Design, Technology and Education, 2015, 8, 2, 162-172

[12] Liang, Y., Websites Vs. Apps: A Comparison of Consumer Acceptance of Apparel Mass-Customization Across Channels, Louisiana State University, Doctoral Dissertations, 2016

[13] Bhaduri, G., Kim, J., "Just for you”: Unveiling the Traits of the Mass-Customized Clothing Shoppers, In: International Textile and Apparel Association (ITAA) Annual Conference Proceedings, 2018, 45

[14] Bhaduri, G., Kim, J., Impact of Individual's Regulatory Focus on Value Perceptions of and Willingness to Invest towards Online Mass-Customized Fashion, In: Industry and Education, 2018, 16, 1, 1-18

[15] Yang, J. H., Chen-Yu, J., Consumer Characteristics and Purchase Intentions of Mass-customized Men's Dress Shirts, In: International Textile and Apparel Association (ITAA) Annual Conference Proceedings, 2014, 94

[16] Kang, J.Y.M., Kim, E., e-Mass customisation apparel shopping: effects of desire for unique consumer products and perceived risk on purchase intentions, In: International Journal of Fashion Design, Technology and Education, 2012, 5, 2, 91-103

[17] Zhang, Y., Li, L., Xing, X., Research on Collaborative Design Method for Apparel Mass Customization in the Internet Plus Era, In: International Journal of Economics, Finance and Management Sciences, 2016, 4, 6, 369-377

[18] Yeung, H.T., Choi, T.M. Mass customisation in the Hong Kong apparel industry, In: Production Planning \& Control, 2011, 22, 3, 298-307

[19] Park, M., Yoo, J., Benefits of mass customized products: moderating role of product involvement and fashion innovativeness, In: Heliyon, 2018, 4, 2, e00537

[20] Larsson, J., Customer perspective on mass-customized knitwear, In: Fashion Practice, 2012, 4, 2, 177-195

[21] Ribeiro, L.S., Duarte, P.A.O., Miguel, R., Online consumer behaviour of mass-customised apparel products: $A$ hierarchy of traits approach, In: Journal of Fashion Marketing and Management, 2017, 21, 2, 158-171

[22] Kim, D.E., LaBat, K., Consumer experience in using 3D virtual garment simulation technology, In: Journal of the Textile Institute, 2013, 104, 8, 819-829

[23] Özbek, A., Topaklı, A., Online Mass Customized T-shirt Design, In: Vocational Education (NWSAVE), 2019, 14, 3, $1-10$

[24] Dellaert, B.G., Dabholkar, P.A., Increasing the attractiveness of mass customization: The role of complementary on-line services and range of options, In: International Journal of Electronic Commerce, 2009, 13, 3, 43-70

[25] Peterson, J., Larsson, J., Carlsson, J., Andersson, P., Knit on demand-development and simulation of a production and shop model for customised knitted garments, In: International Journal of Fashion Design, Technology and Education, 2008, 1, 2, 89-99

[26] Khan, T., Syed, A.H., Hashmi, A., An E-Commerce based Web Portal to Support Customize Clothes for Obese People, In: VFAST Trans. Softw. Eng, 2016, 10, 2

[27] Esmer, Y, Pabuçcu, H., Strategic Career Planning: Fuzzy Logic Approach, In: İzmir Journal of Economics, 2019, 34, 1, 111-124, https://doi.org/10.24988/ije.2019341835

[28] Türkiye İstatistik Kurumunun (TÜIK), Istatistiklerle Gençlik 2017, Available at: http://www.tuik.gov.tr/PreHaber Bultenleri.do?id=27598 [Accesed February 2019]

[29] Yüksek Öğretim Bilgi Yönetim Sistemi, Öğrenim Düzeyine Göre Öğrenci Sayısı, Available at: https://istatistik. yok.gov.tr/ [Accesed February 2019]

[30] Yayla, A.Y., Yıldız, A., How Product Development Accelerating Approaches Influence Product Development Performance - An Empirical Study in Turkish Automotive Sub-Industry, In: European Journal of Social Sciences, 2010, 18, 2

Author:

AHMET ÖZBEK

Marmara University, Faculty of Technology, Textile Engineering Department, Göztepe Kampüsü, 34722, Kadıköy - İstanbul, Turkey

Corresponding author:

AHMET ÖZBEK

e-mail: aozbek@marmara.edu.tr 


\title{
Effects of environmentally friendly degumming methods on some surface properties, physical performances and dyeing behaviour of silk fabrics
}

\author{
DOI: 10.35530/IT.071.04.1675
}

TUBA TOPRAK

PERVIN ANIS

MINE AKGUN

\author{
ABSTRACT - REZUMAT
}

\section{Effects of environmentally friendly degumming methods on some surface properties, physical performances and dyeing behaviour of silk fabrics}

In this paper, the effect of degumming processes on the physical performance, surface properties and colour coordinates of silk fabrics at high temperature and enzymatically, which was developed as an alternative to conventional method, has been investigated. Degummed silk fabrics were compared in terms of weight loss, bending length, tear and breaking strength, surface roughness and friction coefficient. After these tests, acid dyeing was performed to observe different degumming methods effect on dyeing behaviour of degummed silk fabric. The colour coordinates were evaluated by $L^{*}, a^{*}, b^{*}, C^{*}, h^{0}, K / S$, and $\Delta E^{*}$ values. The results revealed that despite insignificant differences between conventional and alternative methods in terms of physical performance and surface properties, the conventional method gave slightly better results than the others. There were no significant differences in colour depth between the two processes. These reasons showed that the alternative method could be used instead of the traditional method and a more sustainable process has been designed.

Keywords: degumming, enzyme, environmentally friendly, friction, roughness, silk

Influența metodelor ecologice de degomare asupra unor proprietăți de suprafață, performanțe fizice și comportamentul la vopsire al țesăturilor din mătase

În această lucrare, a fost analizată influența proceselor de degomare la temperatură ridicată și prin procedeu enzimatic, realizate ca o alternativă la metoda convențională, asupra performanței fizice, proprietăților de suprafață și coordonatelor colorimetrice ale țesăturilor din mătase. Țesăturile din mătase degomate au fost comparate din punctul de vedere al pierderii de masă, lungimii de încovoire, rezistenței la sfâșiere și rupere, rugozității suprafeței și coeficientului de frecare. După aceste teste, a fost realizată vopsirea cu coloranți acizi, pentru a se observa influența diferitelor metode de degomare asupra comportamentului la vopsire al țesăturii din mătase degomată. Coordonatele colorimetrice au fost evaluate prin valorile $L^{*}, a^{*}, b^{*}, C^{*}, h^{0}, K / S$ și $\Delta E^{*}$. Rezultatele au relevat faptul că, în ciuda diferențelor nesemnificative dintre metodele convenționale și cele alternative în ceea ce privește performanța fizică și proprietățile de suprafață, metoda convențională a dat rezultate puțin mai bune decât celelalte. Nu au existat diferențe semnificative de intensitate a culorii între cele două procese. Aceste argumente au demonstrat că metoda alternativă ar putea fi utilizată în locul metodei tradiționale și a fost proiectat un proces mai sustenabil.

Cuvinte-cheie: degomare, enzimă, ecologic, frecare, rugozitate, mătase

\section{INTRODUCTION}

Because of its comfort, elegance, sensuousness, luster, glamour and excellent mechanical properties, silk fiber is called "Queen of Textiles" and has been used for 5000 years [1-6]. Although the annual production of silk fiber is not very high, it remains a special fiber used in high value textile products. Increasing demand for natural fibers to meet environmental and consumer demands will lead to an increase in the use of this fiber [7].

The silk fibers obtained from the silk worm and it consists of mainly sericin (20-30\%), fibroin (65-75\%). There is about $5 \%$ water, wax, pigments, sugars, and mineral salts in the silk fiber $[4,8]$. Sericin covers a pair of fibroin filaments and allows them to stay together [9-11]. Fibroin and sericin proteins differ from each other in amino acid percentages and configurations. The fibroin formed by amino acids with about $76 \%$ non-polar side groups surrounds by sericin which consist $75 \%$ amino acids with polar groups [4, 12-13]. Fibroin is a dense structure of B-sheet microcrystals, whereas sericin is an amorphous structure [3,14]. These differences in configuration and composition of the fibroin and sericin make it possible for fibroin to contribute to the strength and stiffness, while the sericin that holds the fibroin together makes it more water soluble than fibroin $[6,15-17]$. While sericin causes the fiber to become stiff and harsh, it also hinders luster and whiteness of the silk, and prevents penetration of solutions used in 
textile wet processes [18]. Therefore, sericin has to be removed to make silk fiber the ideal fiber for textile industry [9]. In the process of removing sericin from the fiber, degumming, sericin is hydrolyzed and the amide bonds in the protein molecules are broken down [15]. Degumming, which causes a 20-25\% reduction in the weight of the fiber $[3,19]$, can be carried out with water under high pressure [20], by boiling in a soap-alkaline [8, 21-22] or acidic mediums [23-25], or enzymatically [4, 17]. The magnetic field also was used for degumming by Valu [26]. The recommended method is to boil with soap in the presence of alkali, but the chemicals used make it nonenvironmentally friendly [21, 27-29].

The $-\mathrm{NH}_{2}$ and $-\mathrm{COOH}$ groups in the chemical structure of the silk fiber enable this fiber to be dyed with acid, basic, metal complex, mordant, natural, and reactive dyes. The interaction between the dyestuff and the silk fiber occurs with ionic or covalent bonds. The choice of dyes depends on the shade, brightness and fastness grade properties. Acid dyes are used mostly and they are easily absorbed into fibers and washing fastness is poor to moderate [19, 21, 30-32].

Finishing processes to impart various handling and performance properties gain to textile materials such as smoothness, stiffness, softness, crease recovery, dimensional stability, and strength can also be done to change the frictional resistance of fabrics. Friction resistance is influential on abrasion, wear resistance, degree of consolidation and shrinkage properties, especially the key of the fabrics. Friction properties are also important in determining roughness, smoothness and other surface characteristics. While friction studies have been carried out on metals in the past, non-metals, which are the elastomers, plastics, and fibers, friction characteristics have begun to be studied in detail, and even this century can be called the "renaissance of tribology". Friction, a surface phenomenon, has long been used for the objective measurement of surface smoothness. Although friction is a surface property, it is also influenced by the bulk property and therefore the changes in the friction are also sensitive to the type of yarn mechanical properties, fabric structure, finishing process and also the conditions used during testing [33].

In this study, weight loss, bending lengths, tear and breaking strengths of the silk fabrics have been investigated for the possibility of environmental degumming with using enzyme and high temperature conditions as alternatives to conventional degumming. Silk fabric handling is one of the most attractive features for customers. That's why surface characteristics were analysed via surface roughness and friction coefficients after degumming processes. Differences created by different degumming processes on the dyeing properties of silk fabrics have also been investigated.

\section{EXPERIMENTAL WORK}

Material

A fine-medium weight $\left(76 \mathrm{~g} / \mathrm{m}^{2}\right) 100 \%$ silk plain woven fabric was used. This raw silk fabric was provided by Bursa Ijpek. The fabric properties are shown in table 1.

Table 1

CONSTRUCTIONAL PROPERTIES OF SILK FABRIC SAMPLE

\begin{tabular}{|l|c|c|}
\hline \multicolumn{1}{|c|}{ Parameters } & Warp & Weft \\
\hline Yarn count $(\mathrm{Nm})$ & 151 & $151 / 2$ \\
\hline Yarn density (thread/cm) & 26 & 18 \\
\hline Yarn twist $(\mathrm{T} / \mathrm{m})$ & Non-twisted & 248 \\
\hline
\end{tabular}

The commercial acid dye (Lanaset Red 2B), wetting agent (Albaflow Jet) and leveling agent (Albegal) were kindly provided by Huntsman Cooperation, Turkey. Sodium sulfate, acetic acid, sodium bicarbonate and Marseilles soap were analytical reagent grades. Savinase 16L, protease (Novozymes), which was produced from Bacillus sp was used in enzymatic degumming processes.

\section{Method}

\section{Degumming and dyeing}

The degumming processes were grouped into three groups: boiling off with soap in alkaline medium, enzymatic degumming, and high temperature (HT) degumming. Marseilles soap was used in the conventional process based on comparing the effectiveness of the other degumming processes. Silk fabrics were treated conventionally with $3.5 \mathrm{~g} / \mathrm{l}$ Marseille soap, $2.5 \mathrm{~g} / \mathrm{l}$ sodium bicarbonate $(\mathrm{pH} 9.5)$ at $95^{\circ} \mathrm{C}$ for 45 min with an LR value of $25: 1$. For degumming with enzymes in all experiments $8 \%$ enzyme was used in $\mathrm{pH} 8.5$ medium which was adjusted with sodium bicarbonate and was recommended by Novozymes. The conditions of the enzymatic degumming were $50^{\circ} \mathrm{C}$ for 20 min (LR 25:1). The HT degumming processes were operated at the $110^{\circ} \mathrm{C}$ for 20 and 30 minutes and named as HT 20' and HT 30', respectively. For enzymatic and conventionally degummed fabrics, neutralization process was operated with acetic acid. Finally, all degummed fabrics were rinsed water at $70^{\circ} \mathrm{C}$ for 10 minutes two times.

The woven silk fabrics were dyed using exhausting method under laboratory conditions. In the dyeing experiments, the fabric samples weighed $10 \mathrm{~g}$ and the liquor ratio was $25: 1$. The dyebaths contained $2 \%$ owf (on-weight-fabric) acid dye, $1 \mathrm{~g} / \mathrm{l}$ penetration agent, $5 \%$ owf sodium sulphate, and $1 \%$ owf acetic acid. In the dyeing bath at $40-50^{\circ} \mathrm{C}$ containing acetic acid and sodium sulphate fabric was treated for ten minutes. Then, acid dye was put into the bath and the temperature was raised to $80-85^{\circ} \mathrm{C}$ at a rate of $1^{\circ} \mathrm{C} /$ minute. The dyeing was continued at this temperature for 60 minutes to allow good penetration of the dyes and level dyeing. Later the samples were 
taken out of the dyeing tubes and were rinsed with hot $\left(70^{\circ} \mathrm{C}\right)$ and cold water $\left(30^{\circ} \mathrm{C}\right)$ for 10 minutes, respectively. After rinsing the samples were left to dry under laboratory conditions.

The degumming processes were performed with ATAÇ Dyetech Sample Dyeing Machine and the ATAÇ Mini Bobbin Dyeing Machine (MBB01-02F). For dyeing process, ATAÇ Dyetech Sample Dyeing Machine was used. The raw silk fabric was used without further treatment for all experiments for comparison. Each experiment was performed by nondyed silk fabric at three times.

The effects of degumming methods and dyeing were analysed with the following tests.

\section{Bending length}

Bending lengths of fabrics were measured according to "Standard Test Method for Stiffness of Fabrics ASTM D 1388-96" test method by SDL ATLAS Fabric Stiffness Tester M003B.

\section{Tear strength}

The Power Tear (SDL ATLAS M008HE) was used to measure the tear strengths according to "TextilesTear properties of fabrics - Part 1: Determination of tear force using ballistic pendulum method (Elmendorf) (TS EN ISO 13937-1:2000)".

\section{Breaking strength}

The Shimadzu AG-X plus was used for measuring the breaking strengths of the fabric via ASTMD 1682-64.

Surface roughness test

Surface roughness values of silk samples were measured by a roughness tester (Accretech Surfcom $130 \mathrm{~A}$ ) and surface roughness values were recorded according to ISO 4287-1997. The measurement was performed on steady state without causing any further tension on the sample. Three roughness measurements were made on each direction (warp and weft) with the selected measurement parameters of $50 \mathrm{~mm}$ evaluation length ( $0.8 \mathrm{~mm}$ cut-off value) and $1.5 \mathrm{~mm} / \mathrm{s}$ measurement speed. Three measurements were recorded in each directions and the mean was calculated.

$R_{a}$ is the arithmetical average of absolute values of the profile variations (peaks and valleys) from the mean line in the evaluation length [34-36]. This value was calculated using equation 1 :

$$
R_{a}=\frac{1}{n} \sum_{i=1}^{n}\left|y_{i}\right|
$$

where $n$ is the number of samples along the evaluation length and $y_{i}$-(surface height) deviation.

\section{Friction coefficient test}

The static and kinetic friction coefficients used to evaluate the friction characteristics of the fabrics were measured according to ASTM D 1894-14: 2014 standard on a Labthink Param MXD-02 friction coefficient test device.

Static and kinetic friction coefficients of the silk fabric were measured by fabric-to-fabric friction by using standard abrasive wool fabric (ASTM D 4966) (i.e. friction coefficients of sample were measured by silk fabric-to-abrasive wool fabric). The silk fabric sample under test was mounted on the sled (mass of sled: $200 \mathrm{~g}$ ) and standard abrasive wool fabric was mounted on the moving plate (the test speed: $150 \mathrm{~mm} / \mathrm{min}$; the measurement length: $150 \mathrm{~mm}$ ) of the coefficient tester. Friction measurements were performed in warp and weft directions of fabric samples under test. Three measurements were recorded in each directions and the mean was calculated.

\section{Colour measurement}

The colour coordinates of samples were measured by Konika - Minolta 3600D reflectance spectrophotometer coupled to a $\mathrm{PC}$, at wavelengths between 400 and $700 \mathrm{~nm}$ under D $65 / 10^{\circ}$ illuminant with specular component included ( $\mathrm{SCl}$ mode). The percentage reflectance values at the wavelength of maximum absorption (500 nm) were recorded. The conventionally treated fabrics were taken as the standards and the other fabrics were taken as the samples when calculating the colour differences. CIELAB (1976) equation 2 was used to calculate colour differences:

$$
\Delta E_{C I E L A B}^{*}=\sqrt[2]{\left(\Delta L^{*}\right)^{2}+\left(\Delta a^{*}\right)^{2}+\left(\Delta b^{*}\right)^{2}}
$$

where $\Delta L^{*}$ is the lightness difference, $\Delta a^{*}$ - red/green difference, $\Delta b^{*}$ - yellow/blue difference.

The $K / S$ value was calculated for the wavelength corresponding to the maximum absorption value. The $\Delta E^{*}$ was calculated according to CIELAB 1976 equation 3:

$$
K / S=\frac{(1-R)^{2}}{2 R}
$$

where $R$ is the decimal fraction of the reflectance of fabric, $K-$ the absorption coefficient, $S$ - the scattering coefficient.

\section{RESULTS AND DISCUSSION}

\section{Weight loss}

Figure 1 shows the average weights of the fabrics after different degumming methods.

The lowest weight was obtained by conventional method. It was worth noting that this process showed a very high degumming efficiency. The conventional process caused about $25 \%$ weight losses indicated the target value for complete degumming, as obtained under standard conditions with soap and alkali. Without enzymes, the HT 30' degumming process loss was very close to the conventional treatment and differences between them was negligible

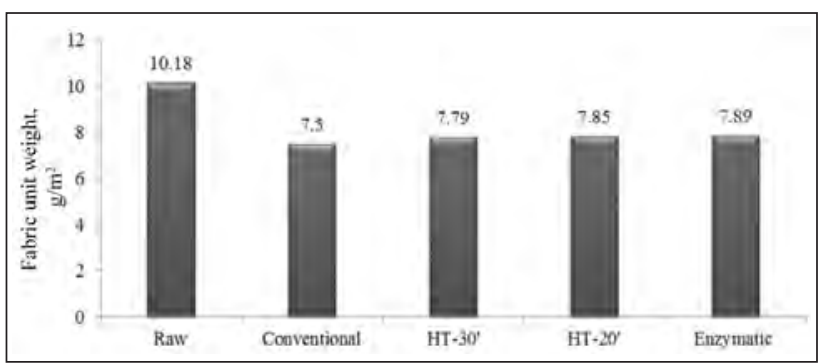

Fig. 1. Weights of silk fabrics after different degumming processes 
$(\approx 5 \%)$, owing to the highest treatment temperature. Compared to HT 30', the HT 20' caused almost 5\% less weight loss because the time was less than 10 minutes. Degumming loss with enzyme was approximately same with the HT 20' process. The protease enzyme used in this study allowed a $10 \%$ difference to the targeted loss of weight $(\approx 25 \%)$ under the adopted experimental conditions.

\section{Bending length}

The bending length values, one of the performance characteristics, are shown in figure 2.

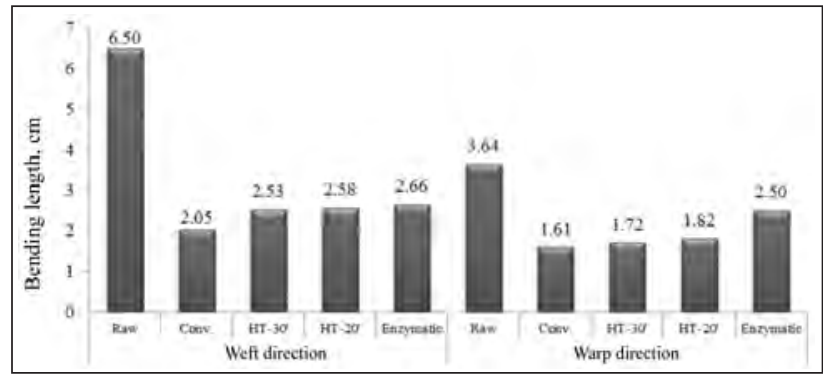

Fig. 2. Bending length values of silk fabrics after different degumming processes

The silk fabrics degummed with conventional method showed the lowest bending lengths since the sericin which gives the fabric hardness was removed at the maximum amount. There were no significant differences between these values for HT 20' and HT 30'. The bending length values obtained by the enzymatic process were slightly higher because the enzymatic process removed the sericin less than HT 20'HT 30' and the conventional methods, whereas the success of this method was significantly prominent when compared with the raw fabric. Moreover, this result indicated that enzymatic degummed fabric structure was harder than the others, except raw. By comparing the fabrics degummed with the conventional and environmentally friendly methods, it was possible to observe that the latter exhibited a bit harder fabrics, especially enzymatically treated one. These results were parallel to the weight loss values of the fabrics, and the fabrics exhibited the greatest and least weight loss gave the lowest and the highest bending lengths, respectively. This could be interpreted as the fabric became softer when sericin moved away from the fabric, thus reducing the bending length of the fabric because sericin gives the fabric rigidity.

\section{Tear strength}

The main effect of degumming processes for fabric tear strengths are given in figure 3 .

It could be seen that the starting with tear strength of the raw silk fabric $(43.19 \mathrm{~N})$ for weft direction, it increased after degumming processes. This increase in tear strength could be explained by removing the sericin which prevents the ability of the yarns to move together against the tear force applied to the fabric. When the degumming processes were compared

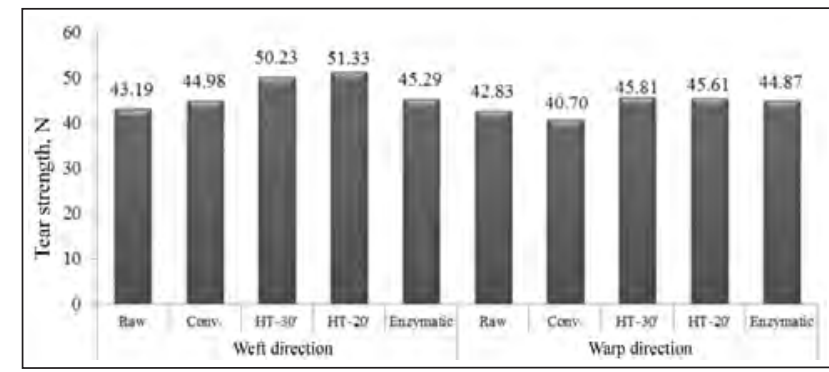

Fig. 3. Tear strengths of degummed silk fabrics with various degumming processes

with each other, the lowest results were obtained with the conventional process. The possible reason for the highest tear strength loss was not only the sericin in the amorphous structure but also the fibroin structure in the crystalline structure was damaged in the conventional degumming process which operated under alkaline conditions [1]. The HT 20' and HT 30' conditions gave higher tear strength values in the weft direction than the enzymatic process. It could be seen that ten minutes difference between the HT processes did not cause any significant change in the tear strength values both of the direction. When effects of degumming processes on the tear strength values at the weft and warp directions were compared to the raw fabrics, the differences in the weft direction were more pronounced, which was thought to have stemmed from the two-ply weft yarn.

\section{Breaking strength}

The effect of degumming processes under investigation could be realized by comparing the breaking strength, which was one of the physical properties of the fabric, is shown figure 4.

Based on breaking strength, the raw silk fabrics had the highest strength, implied that the sericin reinforced to the fabric, so the removing sericin with various degumming methods led to a decrease in the breaking strength. This reduction was the most in conventional process as expected because the sericin was removed at the most amount in the conventional process (figure 1). Another possible reason for this loss was the conventional process conditions caused fiber degradation [1]. When HT 20', HT 30',

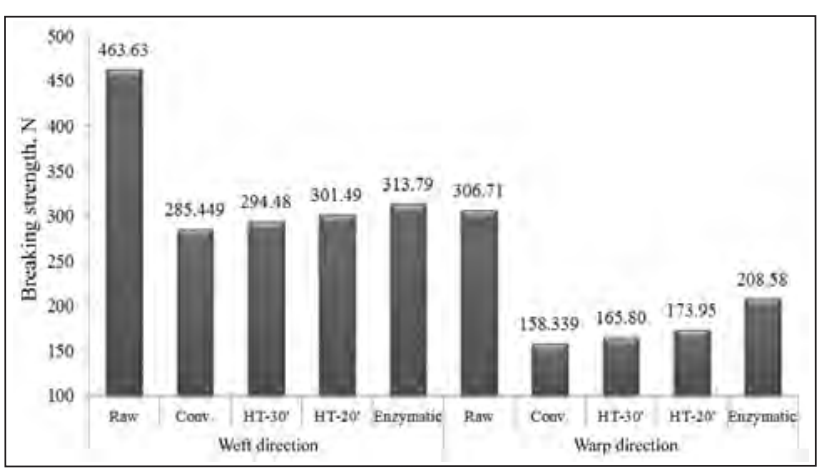

Fig. 4. Breaking strengths of degummed silk fabrics 
and enzymatic degumming processes were compared among themselves, it was seen that the HT processes had lower breaking strength values. It had also turned out that the difference in the process times of HT processes did not cause any significant change $(\approx 2-4 \%)$. Since the working conditions in the enzymatic process were milder and the amount of sericin removed from the fiber by this process was less, so the least strength loss was seen in this method. Although this loss was the least in the enzymatic process compared to other degumming processes, the loss of strength was about $32 \%$ compared to the raw silk fabric. Since two-ply yarn was used in the weft direction, it was seen that the strength of this direction was higher than the warp direction.

\section{Surface roughness}

In figure 5, the changes in the surface roughness values of the weft and warp directions of the silk fabrics, in accordance with the different sericin removing methods, are presented.

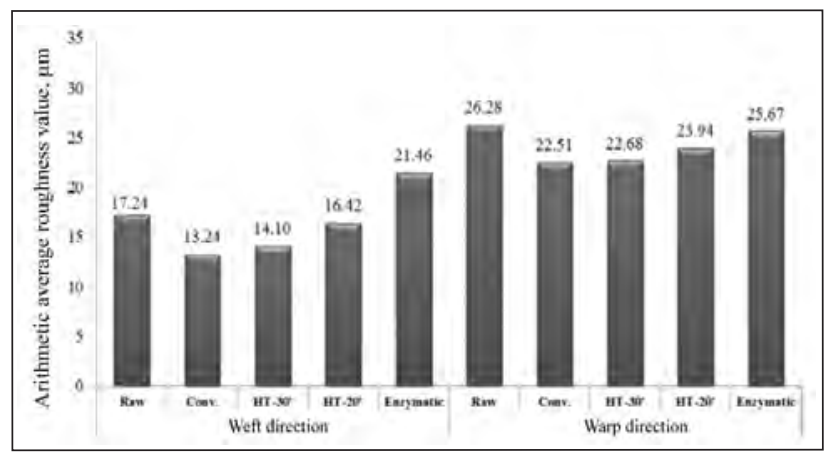

Fig. 5. Surface roughness values of silk fabrics with various degumming processes

In order to evaluate the effect of sericin on the surface roughness, it was observed that the raw fabric had a higher surface roughness compared to the conventionally degumming method by which the sericin was removed at the maximum amount through the fabric. In the conventional method, it was considered that the sericin-removed fibroin has a smoother surface because of its lower results. It was thought that higher values were obtained in the enzymatic process than other degumming methods because the sericin on the surface cannot be removed completely and properly. The surface roughness results at $\mathrm{HT}$ processes were lower than the enzymatic process and but they were higher than the conventional process. The data of HT 30' indicated that sericin was more uniformly removed from the surface than HT 20'. In general, these results showed that sericin increased the surface roughness of the fabrics, that is, all degumming processes made the surface of the fabrics smoother.

For all processes, when the weft and warp direction roughness values were compared, it was observed that the higher results were obtained in the warp direction. This could stem from differences in the density and count of warp and weft yarns. During the measurement of the roughness in the warp direction, the stylus probe of the roughness measurement device moves on the cross direction on each of the thread spacing of individual weft yarns in the fabric structure. Taking into consideration that the weft yarn density constituting the fabric were lower than the warp yarn density, this state caused higher thread spacing of individual weft yarns, as a result the roughness values of fabrics obtained from the warp direction were determined to be higher than the roughness values of fabrics obtained from the weft direction. An increase in yarn density decreased the gaps between the yarn peaks, giving a decrease in surface roughness [35-36]. Also, the coarse structure of weft yarn (weft yarn thickness two times higher than the warp yarn) could have led to a higher yarn peaks on the surface during the measurement of the roughness in the warp direction, and as a result the fabric surface roughness increased in the warp direction.

\section{Friction coefficients}

In figure 6, the changes in the friction coefficient values of the weft and warp directions of the silk fabrics, in accordance with the different sericin removing methods, are presented. The raw fabric gave the lowest friction coefficient values in both directions and these values increased after degumming processes. Sericin in raw silk fabric provided low friction coefficient values because it made fabric structure stiffer and it had not adhesive feature which occurs by fabric-to-fabric friction. After the degumming process, it was observed that this process made the silk fabric feel smoothly handle and increased potential of the fabric to stick or cling to the other surfaces. As a result of this, the friction coefficient values of silk fabrics increased after degumming processes. When the degumming processes were compared in both directions, it was observed that the friction coefficient values were almost close to each other in the warp direction, but the values of the friction coefficients were slightly more pronounced in in the weft direction. When the differences between the degumming processes in the weft direction were analysed, it was seen that the amount of sericin left on the fabric surface was related to the friction coefficient. It could be

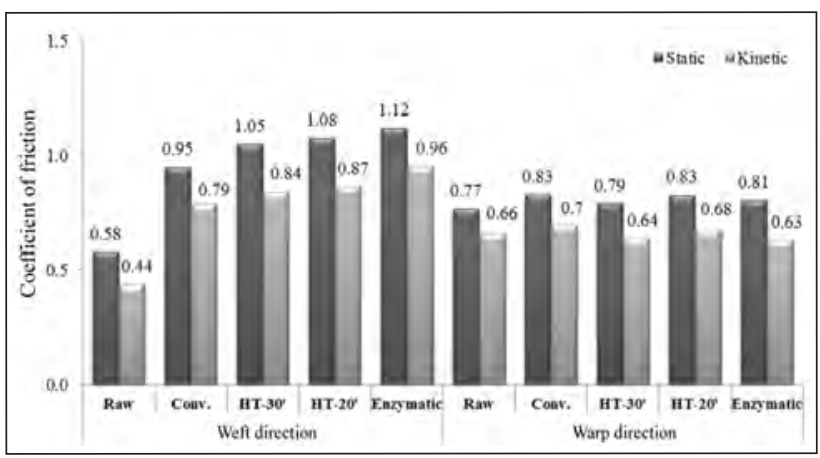

Fig. 6. Friction coefficient values of silk fabrics with various degumming processes 


\begin{tabular}{|c|c|c|c|c|c|c|c|}
\hline \multicolumn{7}{|c|}{ COLOUR COORDINATES OF SILK FABRICS WITH VARIOUS DEGUMMING PROCESSES } \\
\hline Process & $\mathbf{L}^{*}$ & $\mathbf{a}^{*}$ & $\mathbf{b}^{*}$ & $\mathbf{C}^{*}$ & $\mathbf{h}^{\mathbf{*}}$ & \multicolumn{1}{|c|}{ K/S } & $\Delta \mathbf{E}^{*}$ \\
\hline HT20' & 49.10 & 50.25 & 17.32 & 52.98 & 19.01 & 8.20 & 0.53 \\
\hline HT30' & 49.28 & 50.39 & 17.47 & 53.27 & 18.79 & 8.24 & 0.46 \\
\hline Enz. & 48.75 & 50.10 & 17.05 & 52.92 & 19.11 & 8.48 & 0.84 \\
\hline Conv. & 49.42 & 50.60 & 17.09 & 53.41 & 18.66 & 8.68 & - \\
\hline
\end{tabular}

interpreted that the remaining sericin on the surface enhanced the irregularity, which in turn increased the friction coefficient.

\section{Colour coordinates}

The colorimetric coordinates $\left(L^{*}, a^{*}, b^{*}, C^{*}, h^{\circ}\right), K / S$, and $\Delta \mathrm{E}^{*}$ values of all the dyed fabrics are given in table 2.

The $L^{*}$ values given in table 2 revealed that the enzymatic degummed fabrics had the lowest $L^{*}$ values, i.e. darker than the others. However, it seemed that the difference between these values and others was not very high. In table 2 , it could be seen that the values of $a^{*}$ (redness) were higher than those of $b^{*}$ (blueness) as expected because red dyestuff was used. The $a^{*}, b^{*}, C^{*}$ and $h^{\circ}$ values for each process were very close to each other. It was also observed from the $\Delta \mathrm{E}^{*}$ values that the differences between them were negligible $(<1)$. The differences between them were less than 1 could be interpreted as each could be used as an alternative process. Moreover, this was expected because the removed sericin amounts of alternative processes were about the same. Colour strength (K/S), which was the most important parameter to test the quality measurement of a sample in terms of depth of the colour, showed similar results to each other. Additionally, with the help of alternative methods, levelled dyeing could be achieved.

\section{CONCLUSIONS}

In this study, the effects of different degumming processes applied to $100 \%$ silk woven fabric on the mechanical properties (weight loss, bending length, tear strength, breaking strength), surface properties (roughness and friction coefficient) and colour coordinates $\left(L^{*}, a^{*}, b^{*}, C^{*}, h^{\circ}, K / S\right.$ and $\left.\Delta E^{*}\right)$.

According to the results, despite the sericin was removed at the most amount by conventional method (as seen from the changes in the weight loss and bending length values), it had been found that the other alternative methods (HT and enzymatic) gave similar values to those obtained from the conventional process. When the effect on the fabric strength values (tear and breaking strength) of the different degumming processes were examined, it was seen that the most loss of strength was seen in the fabric treated with conventionally where the sericin was removed the most amount. The breaking strength values of the enzymatically treated fabrics were highest.

When the effects of different degumming treatments on the fabric surface properties (roughness and friction coefficient) were examined, it was seen that the lowest surface roughness values were obtained by the conventional process. With the enzymatic process, roughness values were high because of the sericin remaining on the surface of fiber. When the friction coefficient values were examined, it was observed that the coefficient of surface friction of the sericin-free fabric was increased. This was due to the sticking or clinging effect between the sericin and the other surface it touches, due to the softer handling of the degummed fabric. It had been observed that the different sericin removal processes gave nearly similar results on the fabric friction coefficients.

After different degumming processes, the silk fabric colour coordinates $\left(\mathrm{L}^{*}, \mathrm{a}^{*}, \mathrm{~b}^{*}, \mathrm{C}^{*}, \mathrm{~h}^{\circ}, \mathrm{K} / \mathrm{S}\right.$ and $\left.\Delta \mathrm{E}^{*}\right)$ showed that the results obtained with degumming processes results were similar to each other. Although the highest colour difference value was 0.84 between conventional and enzymatic degumming, this difference value was also insignificant because it was below 1 .

As a result, it had been observed that degumming processes with alternative methods had no negative effects on the physical and surface properties of silk fabrics. The colour coordinates and uniform dyeing obtained by the dyeing after the application of these methods to silk fabrics showed they could be alternatively used. Furthermore, other advantages of environmentally degumming processes were the lack of chemical usage and short processing times.

\section{REFERENCES}

[1] Padaki, N.V., Das, B., Basu, A., Advances in understanding the properties of silk, In: Basu, A., editor. Adv. Silk Sci. Technol., Amsterdam: Elsevier Ltd., 2015, 1-16, https://doi.org/10.1016/B978-1-78242-311-9.00001-X

[2] Dash, B.C., Mandal, B.B., Kundu, S.C., Silk Gland Sericin Protein Membranes: Fabrication and Characterization for Potential Biotechnological Applications, In: J. Biotechnol., 2009, 144, 321-329, https://doi.org/10.1016/ j.jbiotec.2009.09.019 
[3] Mahmoodi, N.M., Moghimi, F., Arami, M., Mazaheri, F., Silk Degumming Using Microwave Irradiation as an Environmentally Friendly Surface Modification Method, In: Fibers Polym., 2010, 11, 234-240, https://doi.org/ 10.1007/s12221-010-0234-2

[4] Arami, M., Rahimi, S., Mivehie, L., Mazaheri, F., Mahmoodi, N., Degumming of Persian Silk with mixed Proteolytic Enzymes., In: J. Appl. Polym. Sci., 2007, 106, 267-275, https://doi.org/10.1002/app.26492

[5] Rippon, J.A., Evans, D.J., Improving the Properties of Natural Fibres by Chemical Treatments, In: Kozlowski, R., editor. Handb. Nat. Fibres, Woodhead Publishing Limited, 2012, 63-140, https://doi.org/10.1533/ 9780857095510.1 .63

[6] Asakura, T., Kaplan, D.L., Silk Production and Processing, In: Arutzen, C.J., editor. Encycl. Agric. Sci., New York: Academic Press, 1994, 1-11

[7] Shen, J., Enzymatic Treatment of Wool and Silk Fibres, In: Nierstrasz, V.A., Cavaco-Paulo, A., editors. Adv. Text. Biotechnol., Cambridge: Woodhead Publishing, 2010, 171-192, https://doi.org/10.1533/9780857090232.2.171.

[8] Cao, T.T., Wang, Y.J., Zhang, Y.Q., Effect of Strongly Alkaline Electrolyzed Water on Silk Degumming and the Physical Properties of the Fibroin Fiber, In: PLoS One, 2013, 8, e65654, https://doi.org/10.1371/journal.pone. 0065654

[9] Mossotti, R., Innocenti, R., Zoccola, M., Anghileri, A., Freddi, G., The Degumming of Silk Fabrics: A Preliminary Near Infrared Spectroscopy Study, In: J. Near. Infrared Spectrosc., 2006, 14, 201-208

[10] Magoshi, J., Magoshi, Y., Becker, M.A., Nakamura, S., Biospinning (silk fiber formation, multiple spinning mechanisms), In: Salamone, J.C., editor. Polym. Mater. Encycl., New York: CRC Press, 1996, 132-133

[11] Gulrajani, M.L., Purwar, R., Prasad, R.K., Joshi, M., Studies on Structural and Functional Properties of Sericin Recovered from Silk Degumming Liquor by Membrane Technology, J. Appl. Polym. Sci., 2009, 113, 2796-2804, https://doi.org/10.1002/app

[12] Trotman, E.R., Animal Fibres, In: Trotman, E.R., editor. Dye. Chem. Technol. Text. Fiber. 4th ed., London: Charles Griffin \& Co., 1970, 74-108, https://doi.org/10.1533/9781855738973

[13] Zhang, Y.Q., Applications of Natural Silk Protein Sericin in Biomaterials, Biotechnol. Adv., 2002, 20, 91-100

[14] Takahashi, Y., Gehoh, M., Yuzuriha, K., Crystal Structure of Silk (Bombyx mori), J. Polym. Sci., 1991, 29, 889-891

[15] Chopra, S., Gulrajani, M.L., Comparative Evaluation of the Various Methods of Degumming Silk, Indian J. Fibre Text. Res., 1994, 19, 76-83

[16] Jiang, P., Liu, H., Wang, C., Wu, L., Huang, J., Guo, C., Tensile Behavior and Morphology of Differently Degummed Silkworm (Bombyx mori) Cocoon Silk Fibres, Mater. Lett., 2006, 60, 919-925 https://doi.org/10.1016/ j.matlet.2005.10.056

[17] Freddi, G., Mossotti, R., Innocenti, R., Degumming of Silk Fabric with Several Proteases, J. Biotechnol., 2003, 106, 101-112, https://doi.org/10.1016/j.jbiotec.2003.09.006

[18] Haggag, K., El-Sayed, H., Allam, O.G., Degumming of Silk Using Microwave-Assisted Treatments, J. Nat. Fibers, 2007, 4, 1-22, https://doi.org/10.1300/J395v04n03

[19] Teli, M.D., Advances in the Dyeing and Printing of Silk. In: Basu, A., editor. Adv. Silk Sci. Technol., AMSTERDAM: Elsevier Ltd., 2015, 55-78, https://doi.org/10.1016/B978-1-78242-311-9.00004-5

[20] Zhang, Y.Q., Shen, W.D., Tao, M.L., Zhou, W.L., Ma, Y., Ding, Y., Production Method of Water Soluble Sericin, CN 1477141A, 2004

[21] Shukla, S.R., Manisha, R.M., Low-temperature Ultrasonic Dyeing of Silk, In: Color Technol., 1995, 111, 342-345

[22] Gowda, K.N., Padaki, N.V., Sudhakar, R., Subramani, R., Eco-friendly Preparatory Process for Silk: Degumming by Protease Enzyme, In: Man-Made Text. India, 2007, 50, 28-31

[23] Gulrajani, M.L., Chatterjee, A., Degumming of Silk with Oxalic Acid, In: Indian J. Fibre Text. Res., 1992, 17, 39-44, https://doi.org/10.1111/j.1478-4408.1992.tb00091.x

[24] Gulrajani, M.L., Sethi, S., Gupta, S., Some Studies in Degurnming of Silk with Organic Acids, In: J. Soc. Dye Colour, 1992, 108, 79-86

[25] Khan, M.M.R., Tsukada, M., Gotoh, Y., Morikawa, H., Freddi, G., Shiozaki, H., Physical Properties and Dyeability of Silk Fibers Degummed with Citric Acid, In: Bioresour. Technol., 2010, 101, 8439-8445, https://doi.org/10.1016/ j.biortech.2010.05.100

[26] Valu, F., Homutesko, J., Degumming of Silk in Presence of Magnetic Field for Reduced Degradation, In: Chem. Abstr., 1984, 100, 157-158

[27] Vaithanomsat, P., Kitpreechavanich, V., Sericin Separation from Silk Degumming Wastewater, In: Sep. Purif. Technol., 2008, 59, 129-133, https://doi.org/10.1016/j.seppur.2007.05.039

[28] Gulrajani, M.L., Das, S., Sethi, S., Degumming of Murshidabad Silk Fabrics with Alkalies, In: Indian J. Fibre Text. Res., 1990, 15, 173-179

[29] Fabiani, C., Pizzichini, M., Spadoni, M., Zeddita, G., Treatment of Waste Water from Silk Degumming Processes for Protein Recovery and Water Reuse, In: Desalination, 1996, 105, 1-9, https://doi.org/10.1016/00119164(96)00050-1

[30] Chakraborty, J.N., Dyeing of Silk, In: Chakraborty, J.N., editor. Fundam. Pract. Colouration Text., Cambridge: Woodhead Publishing, 2010, 214-221, https://doi.org/10.1533/9780857092823

[31] Work, R.W., The Force-Elongation Behavior of Web Fibers and Silks Forcibly Obtained from Orb-Web-Spinning Spiders, In: Text. Res. J., 1976, 46, 485-492

[32] Babu, K.M., The Dyeing of Silk. In: Babu KM, editor. Silk Process, In: Prop. Appl., Oxford: Woodhead Publishing, 2013, 117-139, https://doi.org/10.1533/9781782421580.117

[33] Gupta, B.S., Textile fiber morphology, structure and properties in relation to friction, In: Gupta, B.S, editor. Frict. Text. Mater., Cambridge: Woodhead Publishing, 2008, 3-36, https://doi.org/10.1533/9781845694722.1.3 
[34] Gadelmawla, E.S., Koura, M.M., Maksoud, T.M.A., Elewa, I.M., Soliman, H.H, Roughness Parameters, In: J. Mater. Process. Technol., 2002, 123, 133-145, https://doi.org/10.1016/S0924-0136(02)00060-2

[35] Akgun, M., Assessment of the Surface Roughness of Cotton Fabrics Through Different Yarn and Fabric Structural Properties, In: Fibers Polym., 2014, 15, 405-413, https://doi.org/10.1007/s12221-014-0405-7

[36] Akgun, M., Assessment of the Effect of Fabric Constructional Parameters on Surface Roughness of Wool Fabrics, In: J. Text. Inst., 2015, 106, 845-852, https://doi.org/10.1080/00405000.2014.948730

\section{Authors:}

TUBA TOPRAK, MINE AKGUN, PERVIN ANIS

Bursa Uludag University, Faculty of Engineering, Textile Engineering Department, Gorukle Campus,

16059, Nilufer, Bursa, Turkey

e-mail: akgunm@uludag.edu.tr, pervin@uludag.edu.tr

Corresponding author:

TUBA TOPRAK

e-mail: tubatoprak@uludag.edu.tr 


\title{
Comparative assessment of dexterity tests results using two internationally recognized scales in patients with cerebral palsy, users of medical textiles
}

\author{
DOI: 10.35530/IT.071.04.20205
}

\section{ABSTRACT - REZUMAT}

Comparative assessment of dexterity tests results using two internationally recognized scales in patients with cerebral palsy, users of medical textiles

The recent studies report an increase in the percentage of newborns diagnosed with cerebral palsy (CP) in industrialized countries due to the increased survival rate of infants with low birth weight. The assessment of the upper limb motor function and manual skills are important steps in achieving a suitable multi-modal therapeutical plan, aiming at gaining functional independence and early integration into society. The study seeks to identify how the motor deficiency present at the level of the upper limbs influences the manual skills of CP patients reflected in daily activities (Activities of Daily Living $-A D L$ ) and using medical textiles. 35 patients diagnosed with $C P$ were assessed during hospitalization using, for the comparative reflection of $A D L$ dexterity assessment results, at the same patient, quantified, the Action Research Arm Test (ARAT) scale and ABILHAND-Kids. A highly significant correlation was found, the ABILHAND-Kids score being moderately correlated with the ARAT score, obtained in the upper limb with more deficient functionality (0.578) and respectively with better functionality (0.570). The assessment of the child suffering of CP, using the ABILHAND-Kids questionnaire and the ARAT test provides to the rehabilitation team useful information, with the benefit of complementarity for the elaboration, based on several correlated elements, of the case management plan and methodology. Proper treatment, instituted early, can have a favorable influence on the social integration of these people. A remarkable contribution has been made by the textile domain which, through its sustained concerns regarding the research and development of biotechnologies and biomaterials, proves its permanent concern in supporting and integrating these people.

Keywords: upper limb motor function, manual skills/dexterity, day-to-day activities, upper limb motricity disorders, social inclusion

Evaluarea comparativă a rezultatelor testelor de dexteritate utilizând două scale recunoscute la nivel internațional la pacienți cu paralizie cerebrală, utilizatori de textile medicale

Studii recente raportează o creștere a procentului de nou-născuți diagnosticați cu paralizie cerebrală (PC) în țările industrializate datorită creșterii ratei de supraviețuire a sugarilor cu greutate scăzută la naștere. Evaluarea funcției motorii a membrelor superioare și a abilităților manuale sunt pași importanți în realizarea unui plan terapeutic multimodal adecvat, care vizează obținerea independenței funcționale și integrarea timpurie în societate. Prezentul studiu urmărește să identifice modul în care deficiența motorie prezentă la nivelul membrelor superioare influențează abilitățile manuale ale pacienților cu PC reflectate în activitățile zilnice (ADL) și de utilizare a textilelor medicale. 35 de pacienți diagnosticați cu PC au fost evaluați în timpul spitalizării folosind, pentru reflectarea comparativă a rezultatelor evaluării dexterității în ADL, la același pacient, cuantificat, scala de testare Action Research Arm Test (ARAT) și ABILHAND-Kids. S-a găsit o corelație extrem de semnificativă, scorul ABILHAND-Kids fiind moderat corelat cu scorul ARAT, obținut la nivelul membrului superior cu funcționalitate mai deficitară $(0,578)$ și, respectiv, cu o funcționalitate mai bună $(0,570)$. Evaluarea copilului care suferă de PC, folosind chestionarul ABILHAND-Kids și testul ARAT, oferă echipei de recuperare informații utile, cu beneficiul complementarității pentru elaborarea, pe baza mai multor elemente corelate, a planului și metodologiei de gestionare a cazurilor. Tratamentul adecvat, instituit precoce, poate avea o influență favorabilă asupra integrării sociale a acestor persoane. O contribuție remarcabilă o are domeniul textil care, prin preocupările susținute în ceea ce privește cercetarea și dezvoltarea biotehnologiilor și biomaterialelor, dovedește preocuparea permanentă în susținerea și integrarea acestor persoane.

Cuvinte cheie: funcția motorie a membrului superior, abilități manuale/dexteritate, activități cotidiene, tulburări de motricitate la nivelul membrului superior, incluziune socială

\section{INTRODUCTION}

$\mathrm{CP}$ is a group of posture and movement disorders caused by nonprogressive lesions of the central nervous system under development stage [1]. The CP occurs to an average of 1.5-2.5/1000 of newborns [2], of which over $2 / 3$ have mobility difficulties at the level of the upper limb. Recent studies mention the existence of over 17 million patients diagnosed with CP worldwide, of which $39 \%$ are hemiplegic, $38 \%$ diplegic and $23 \%$ tetraplegic [3].

From a clinical point of view, the spastic form prevails - present in $70-80 \%$ of the cases - followed by the 
dyskinetic form - in 10-20\% of the cases - and respectively, the ataxic and mixed forms [4].

Proper treatment, instituted early, can have a favorable influence on the social integration of these people. A remarkable contribution has been made by the textile domain which, through its sustained concerns regarding the research and development of biotechnologies and biomaterials, proves its permanent concern in supporting and integrating these people.

\section{MATERIAL AND METHODS}

In this study, 35 patients diagnosed with CP were assessed during hospitalization at Centrul National Clinic de Recuperare Neuropsihomotorie pentru Copii "Dr. Nicolae Robanescu" (CNCRNC) between September 2018 and February 2019 using, for the comparative reflection of ADL dexterity assessment results, at the same patient, quantified, the Action Research Arm Test scale (ARAT) and ABILHANDKids. The selection of cases for setting up the study group had as criteria for inclusion/exclusion the patients' age and, respectively, their level of cooperation as well as the degree of muscle hypertonia in the shoulder, elbow, fist and fingers. The statistical processing of primary data was performed with the Statistical Package for the Social Sciences SPSS Statistics 24 program.

From our knowledge, ARAT is not a scale currently used for functional assessment of CP children. To shed light on this, we have preliminarily developed an afferent literature review by interrogating the Medline/PubMed [5], PMC [6], Elsevier [7], PEDro [8], ISI Web of Knowledge/Science [9] databases, according to the identification paradigm based on the following keywords: "Action Research Arm Test", "Action Research Arm Test Cerebral Palsy", "ARAT", "ARAT Cerebral Palsy". The search results, after removing redundancies, are shown in table 1.

Considering the above finding, we hope to contribute through this study to the extension of the assessment tools used in the CP with the older but validated (for strokes) ARAT scale [10-11].

The study has been approved by the Ethics Committee of the CNCRNC under no. 9586/15.12. 2017 and was carried out at CNCRNC headquarters. The group of patients enrolled in the study has the following characteristics:

- Age ranging from 6 to 18 years;
- Symmetric gender distribution (randomly occurring): $50 \%$ girls, $50 \%$ boys;

$-37 \%$ diplegic patients, $33 \%$ tetraplegic patients, $30 \%$ hemiplegic patients;

- Spasticity in upper limb mAS < 3;

$-60 \%$ of them had a form of neuropsychomotor developmental delay compatible, however, with an acceptable level of cooperation during the abovementioned assessments.

According to the literature data, the discriminative threshold was located at an Intelligence Quotient (IQ) $=55$ [12].

The patients were tested for the assessment of manual skills and motor deficit of the upper limb in terms of ADL type tasks provided in the ABILHAND-Kids questionnaire portfolio and respectively the motor deficit, quantified by the ARAT scale [13].

The ABILHAND-Kids test is focused on the perception of the assessed child's parents regarding his/her ability to perform certain activities. The questionnaire was developed using the Rasch Measurement Model [14], which provides a method of converting gross scores to a linear measure situated on a one-dimensional scale. The ABILHAND-Kids test has been specially designed for assessing the skills of children with CP. Specialty literature mentions a high reliability $(R=0.94)$ and good reproducibility over time $(R=$ $0.91)$ of this test [15].

The questionnaire [16] contains 21 elements which are designed to estimate how difficult or easy it is for the child to perform the daily tasks without support (even if in the everyday life he/she is supported), regardless of the hand the child uses and regardless of the adopted strategy.

ARAT assesses the motor deficit in the upper limb by measuring the patient's ability to handle objects of different shapes and weights. It is divided into 4 subtests, which, based on 19 elements, assess the Gross Arm Movement, the poly-digito-palmar grasp/prehension (Grasp), the grip/cylindrical clamp (Grip), and the pinch/ two-digit clamp (Pinch).

The studies show an internal consistency of ARAT calculated using the Cronbach Alpha coefficient ( $\alpha=$ 0.98 ) and a reproducibility expressed by a value of "intraclass correlation" coefficients ICCs $=0.97$ excellent, respectively 0.92 inter- and 0.97 intra-observational [17].

For performing the comparative analysis, we first performed the qualitative analogies of functionality

THE NUMERICAL RESULTS OF DATABASES SEARCH AFTER ELIMINATION OF REDUNDANCIES

\begin{tabular}{|l|c|c|c|c|c|c|}
\hline \multicolumn{1}{|c|}{ Keywords } & PubMed & PMC & PEDro & Elsevier & ISI & Total \\
\hline "Action Research Arm Test" & 0 & 19 & 0 & 0 & 0 & 19 \\
\hline "Action Research Arm Test Cerebral Palsy" & 5 & 0 & 0 & 0 & 0 & 5 \\
\hline "ARAT" & 0 & 38 & 0 & 0 & 0 & 38 \\
\hline "ARAT Cerebral Palsy" & 1 & 0 & 0 & 0 & 0 & 1 \\
\hline Total & 6 & 57 & 0 & 0 & 0 & 63 \\
\hline
\end{tabular}




\begin{tabular}{|c|c|c|c|c|}
\hline \multicolumn{5}{|c|}{$\begin{array}{l}\text { QUALITATIVE ANALOGIES OF FUNCTIONALITY BETWEEN THE ELEMENTS QUANTIZED THROUGH } \\
\text { THE ABILHAND-KIDS AND ARAT SCALES }\end{array}$} \\
\hline \multirow{2}{*}{ ABILHAND-Kids } & \multicolumn{4}{|c|}{ ARAT } \\
\hline & Grasp & Grip & Pinch & Gross movement \\
\hline Opening a jar of jam & $\mathrm{X}$ & & & \\
\hline Putting on a backpack & & & & $\mathrm{X}$ \\
\hline Opening a toothpaste tube & & & $\mathrm{X}$ & \\
\hline Opening the package of a chocolate bar & & & $x$ & \\
\hline Washing the upper body & & & & $x$ \\
\hline Rolling the sleeves of a sweater & & & $\mathrm{X}$ & \\
\hline Sharpening a pencil & & $x$ & & \\
\hline Taking off a T-shirt & & & & $x$ \\
\hline Squeezing toothpaste on the toothbrush & & & $\mathrm{X}$ & \\
\hline Opening a bread box/bag & & & $\mathrm{X}$ & \\
\hline Unscrewing a bottle cap & & $\mathrm{X}$ & & \\
\hline Zipping up pants & & & $X$ & \\
\hline Buttoning up a shirt & & & $\mathrm{X}$ & \\
\hline Filling a glass of water & & $\mathrm{X}$ & & \\
\hline Turning on a desk lamp & & & $\mathrm{X}$ & \\
\hline Putting on a hat & & & & $\mathrm{x}$ \\
\hline Buckling a jacket & & $x$ & & \\
\hline Unbuttoning pants & & & $\mathrm{X}$ & \\
\hline Opening a bag of chips & & & $\mathrm{x}$ & \\
\hline Zipping up a jacket & & & $x$ & \\
\hline Removing a coin from a wallet & & & $X$ & \\
\hline
\end{tabular}

between the quantified elements through the two scales, according to table 2 .

Thus, the study aimed at the correlative/comparative analysis after compatibilization of the adequate primary data from the tests performed with the two above-mentioned scales.

The primary data from the assessment of the ADL type activities were collected by means of the questionnaire ABILHAND-Kids, and are shown for each patient, through the responses to the 21 questions, the possible response variants being: impossible (score 0 ), difficult (score 1) and easy (score=2). The data obtained were analyzed using the Rasch model of conversion of raw scores to a linear scale. The manual skills expressed in logits were calculated for a conversion interval of $95 \%$ and they represent the ABILHAND-Kids score. This was analyzed, using the statistical processing IBM SPSS 24 program, in relation to the score ARAT obtained by summing the scores of the four subtests - the gross arm movement (GM), the poly-digito-palmar prehension (PP), the cylindrical clamp (CC) and the two-digit clamp (TDC) - both for upper limb with better functionality (ULBF) and for upper limb with deficient functionality (ULDF). The processed primary data input is presented in table 3.

\section{RESULTS}

The correlation results are shown in table 4.

Results:

- All the correlations are highly significant (significance < 0.001).

- The ABILHAND score is correlated with the ULBF score $(0.570)$, only a little more with the ULDF score $(0.578)$, and some more with the total score (0.622).

\section{DISCUSSIONS}

To our knowledge, the ARAT test has not been used in CP cases assessments, which also results from the afferent literature review elaborated. We consider it useful to employ the association approach in assessing the functionality of the upper limb, especially with regard to manual ability/dexterity, using in each case both a questionnaire (therefore a tool based on parents' responses) and the effective, objective measurement of several motor control parameters.

\section{CONCLUSION}

The results of this study are a premise for the future use of both the ABILHAND-Kids questionnaire and the ARAT test, in the field of pediatric neurorehabilitation, for assessing patients with cerebral palsy. 


\begin{tabular}{|c|c|c|c|c|c|c|c|c|c|c|c|}
\hline \multicolumn{12}{|c|}{ PRIMARY DATA } \\
\hline Patient ID & $\begin{array}{c}\text { Patient } \\
\text { measure }\end{array}$ & $\begin{array}{l}\text { ULBF } \\
\text { PP_I }\end{array}$ & $\begin{array}{l}\text { ULBF } \\
\text { CC_I }\end{array}$ & $\begin{array}{l}\text { ULBF } \\
\text { _TDC_I }\end{array}$ & $\begin{array}{l}\text { ULBF } \\
\text { GM_I }\end{array}$ & $\begin{array}{l}\text { ULDF } \\
\text { PP_I }\end{array}$ & $\begin{array}{l}\text { ULDF } \\
\text { CC_I }\end{array}$ & $\begin{array}{l}\text { ULDF } \\
\text { TDC_I }\end{array}$ & $\begin{array}{l}\text { ULDF } \\
\text { GM_I }\end{array}$ & $\begin{array}{l}\text { ULBF } \\
\text { sum }\end{array}$ & $\begin{array}{l}\text { ULDF } \\
\text { sum }\end{array}$ \\
\hline patient 1 & 4.066 & 17 & 12 & 18 & 9 & 14 & 12 & 18 & 7 & 56 & 51 \\
\hline patient 2 & 5.043 & 18 & 12 & 18 & 9 & 18 & 11 & 18 & 9 & 57 & 56 \\
\hline patient 3 & -3.542 & 18 & 8 & 14 & 8 & 10 & 4 & 12 & 6 & 48 & 32 \\
\hline patient 4 & -0.697 & 16 & 10 & 13 & 9 & 17 & 9 & 12 & 9 & 48 & 47 \\
\hline patient 5 & 6.684 & 18 & 12 & 18 & 9 & 18 & 9 & 18 & 9 & 57 & 54 \\
\hline patient 6 & 6.649 & 18 & 12 & 15 & 9 & 18 & 12 & 17 & 9 & 54 & 56 \\
\hline patient 7 & 1.763 & 6 & 4 & 4 & 7 & 0 & 0 & 0 & 0 & 21 & 0 \\
\hline patient 8 & -3.177 & 10 & 0 & 0 & 6 & 10 & 0 & 0 & 0 & 16 & 10 \\
\hline patient 9 & 2.549 & 17 & 9 & 17 & 9 & 17 & 9 & 15 & 9 & 52 & 50 \\
\hline patient 10 & 2.155 & 13 & 6 & 12 & 7 & 12 & 4 & 12 & 7 & 38 & 35 \\
\hline patient 11 & 0.075 & 18 & 12 & 18 & 9 & 0 & 0 & 0 & 3 & 57 & 3 \\
\hline patient 12 & -0.611 & 17 & 7 & 13 & 8 & 12 & 7 & 12 & 9 & 45 & 40 \\
\hline patient 13 & 3.83 & 18 & 12 & 18 & 9 & 17 & 12 & 18 & 9 & 57 & 56 \\
\hline patient 14 & 0.964 & 18 & 8 & 18 & 9 & 18 & 7 & 11 & 9 & 53 & 45 \\
\hline patient 15 & 0.656 & 18 & 9 & 17 & 9 & 18 & 10 & 15 & 9 & 53 & 52 \\
\hline patient 16 & 6.601 & 18 & 12 & 18 & 9 & 18 & 12 & 18 & 9 & 57 & 57 \\
\hline patient 17 & 3.852 & 18 & 11 & 17 & 9 & 18 & 12 & 17 & 9 & 55 & 56 \\
\hline patient 18 & 6.684 & 18 & 11 & 18 & 9 & 18 & 11 & 17 & 9 & 56 & 55 \\
\hline patient 19 & 1.854 & 17 & 11 & 18 & 0 & 11 & 4 & 6 & 0 & 46 & 21 \\
\hline patient 20 & 3.116 & 18 & 11 & 18 & 9 & 4 & 4 & 0 & 6 & 56 & 14 \\
\hline patient 21 & 4.381 & 18 & 12 & 18 & 9 & 16 & 10 & 16 & 9 & 57 & 51 \\
\hline patient 22 & -1.748 & 15 & 8 & 14 & 9 & 14 & 8 & 8 & 7 & 46 & 37 \\
\hline patient 23 & 6.684 & 18 & 12 & 18 & 9 & 18 & 12 & 18 & 9 & 57 & 57 \\
\hline patient 24 & - & 18 & 12 & 18 & 9 & 18 & 12 & 18 & 9 & 57 & 57 \\
\hline patient 25 & 6.684 & 18 & 12 & 18 & 9 & 18 & 8 & 18 & 9 & 57 & 53 \\
\hline patient 26 & 1.571 & 18 & 11 & 16 & 9 & 18 & 11 & 15 & 9 & 54 & 53 \\
\hline patient 27 & 5.043 & 18 & 12 & 18 & 9 & 18 & 12 & 18 & 9 & 57 & 57 \\
\hline patient 28 & 3.9 & 18 & 12 & 18 & 9 & 18 & 12 & 18 & 9 & 57 & 57 \\
\hline patient 29 & 3.844 & 18 & 11 & 18 & 9 & 18 & 11 & 18 & 9 & 56 & 56 \\
\hline patient 30 & 6.684 & 18 & 12 & 18 & 9 & 15 & 11 & 15 & 9 & 57 & 50 \\
\hline patient 31 & 0.902 & 15 & 8 & 8 & 9 & 10 & 4 & 4 & 8 & 40 & 26 \\
\hline patient 32 & 4.381 & 18 & 12 & 18 & 9 & 18 & 11 & 18 & 9 & 57 & 56 \\
\hline patient 33 & 2.768 & 18 & 12 & 18 & 9 & 17 & 9 & 12 & 7 & 57 & 45 \\
\hline patient 34 & 0.569 & 18 & 12 & 17 & 9 & 15 & 12 & 14 & 9 & 56 & 50 \\
\hline patient 35 & 1.056 & 17 & 8 & 15 & 9 & 14 & 8 & 12 & 9 & 49 & 43 \\
\hline
\end{tabular}

Table 4

\begin{tabular}{|c|l|c|c|c|c|}
\hline \multicolumn{7}{|c|}{ THE CORRELATION RESULTS } \\
\hline \multirow{2}{*}{ Scores } & \multicolumn{1}{|c|}{ Variables } & ABILHAND score & ULBF score & ULDF score & Total score (ULBF+ULDF) \\
\hline \multirow{4}{*}{ ABILHAND score } & Pearson Correlation & 1 & 0.570 & 0.578 & 0.622 \\
\cline { 2 - 6 } & Sig. (2-tailed) & - & 0.000 & 0.000 & 0.000 \\
\cline { 2 - 6 } & $\mathrm{N}$ & 35 & 34 & 34 & 34 \\
\hline \multirow{4}{*}{ ULBF score } & Pearson Correlation & 0.570 & 1 & 0.693 & 0.872 \\
\cline { 2 - 6 } & Sig. (2-tailed) & 0.000 & - & 0.000 & 0.000 \\
\cline { 2 - 6 } & $\mathrm{N}$ & 34 & 35 & 35 & 35 \\
\hline \multirow{4}{*}{ ULDF score } & Pearson Correlation & 0.578 & 0.693 & 1 & 0.957 \\
\cline { 2 - 6 } & Sig. (2-tailed) & 0.000 & 0.000 & - & 0.000 \\
\cline { 2 - 6 } & $\mathrm{N}$ & 34 & 35 & 35 & 35 \\
\hline \multirow{3}{*}{$\begin{array}{l}\text { Total score } \\
\text { (ULBF+ULDF) }\end{array}$} & Pearson Correlation & 0.622 & 0.872 & 0.957 & - \\
\cline { 2 - 6 } & Sig. (2-tailed) & 0.000 & 0.000 & 0.000 & 35 \\
\cline { 2 - 6 } & $\mathrm{N}$ & 34 & 35 & 35 & \\
\hline
\end{tabular}

Note: The correlation is significant at the 0.01 level (2-tailed). 


\section{CONFLICT OF INTEREST}

The authors declare that there are no conflicts of interest in this work.

\section{AUTHORS CONTRIBUTION}

All the authors have contributed equally to the achievement of this work and have approved for its publication.

\section{ACKNOWLEDGEMENT}

The main author thanks to all the co-authors for their excellent collaboration and support in their PhD student activity, the present study being linked to the whole of the PhD work: "Researches on integrated modes for the development of digital and preparatory abilities for writing, for children with cerebral palsy". This research was supported financially by the project CNFIS-FDI-2018-0582 - Supporting Excellence Research within The Bucharest University of Economic Studies in the context of the principles of sustainable development and open research. 6. Supporting field research excellence in universities Beneficiary: The Bucharest University of Economic Studies.

\section{REFERENCES}

[1] Onose, G., Padure, L., Compendiu de neuroreabilitare la adulţi, copii şi vârstnici, Ed. Universitară "Carol Davila", Bucharest, 2008

[2] Garfunkel, L.C., Kaczorowski, J.M., Christy, C., Pediatric Clinical Advisor, 2007

[3] McGillivray, A., General Movements Screening Guideline Women and Babies: General Movements Assessments (GMA) and other assessment modalities for prediction of cerebral palsy and adverse early neurodevelopment in high-risk infants, 2011

[4] Avramescu, E.T., Roşulescu, E., Zăvăleanu, M., Călina, M., Enescu, D., Kinetoterapia în afecțiuni pediatrice, Ed. Universitaria, Craiova, 2007

[5] US National Library of Medicine National Institutes of Health, Available at: https://www.ncbi.nlm.nih.gov/pubmed/ [Accesed March 2020]

[6] PMC, Available at: https://www.ncbi.nlm.nih.gov/pmc/ [Accesed March 2020]

[7] Elsevier, Available at: https://www.elsevier.com [Accesed March 2020]

[8] Physiotherapy Evidence Database, Available at: https://www.pedro.org.axu [Accesed March 2020]

[9] Web of Science, Available at: https://apps.webofknowledge.com [Accesed March 2020]

[10] Yozbatiran, N., Der-Yeghiaian, L., Cramer, S.C., A standardized approach to performing the action research arm test, In: Neurorehabil. Neural Repair, 2008

[11] Muresanu, D.F., et al., Cerebrolysin and Recovery After Stroke (CARS): A randomized, placebo-controlled, double-blind, multicenter trial, In: Stroke, 2016

[12] Cherry, K., How Low IQ Scores Are Determined, 2020, Available at: https://www.verywellmind.com/what-isconsidered-a-low-iq-2795282 [Accesed March 2020]

[13] Action Research Arm Test, Available at : http://www.strokecenter.org/wp-content/uploads/2011/08/action_research arm test.pdf [Accesed March 2020]

[14] Rasch Measurement Model, Available at: http://rssandbox.iescagilly.be/rasch-measurement-model.html [Accesed March 2020]

[15] Arnould, C., Penta, M., Renders, A., Thonnard, J.L., ABILHAND-Kids: A measure of manual ability in children with cerebral palsy, In: Neurology, 2004

[16] ABILHAND-Kids specific to cerebral palsy children, Available at: http://rssandbox.iescagilly.be/abilhand-kidsdownloads.html\#abilhand-kids-specific-to-cerebral-palsy-children [Accesed March 2020]

[17] Nijland, R., Van Wegen, E., Verbunt, J., Van Wijk, R., Van Kordelaar, J., Kwakkel, G., A comparison of two validated tests for upper limb function after stroke: The wolf motor function test and the action research arm test, In: J. Rehabil. Med., 2010

\section{Authors:}

\section{CORINA SPOREA ${ }^{1}$, MARGARETA STELA FLORESCU ${ }^{2}$, DUMITRU FERECHIDE ${ }^{3}$, IOAN CRISTESCU $^{4}$}

${ }^{1}$ Centrul Național Clinic de Recuperare Neuropsihomotorie pentru Copii „Doctor Nicolae Robănescu”, Soldat Dumitru Mincă Street, no. 44, 041408, Bucharest, Romania

${ }^{2}$ Bucharest University of Economic Studies, Faculty of Public Administration and Management,

Piata Romana, no. 6, 010374, Bucharest, Romania

e-mail: margareta.florescu@ari.ase.ro

${ }^{3}$ Carol Davila University of Medicine and Pharmacy, Eroii Sanitari Boulevard, no. 8, Bucharest, Romania e-mail: dferec@yahoo.com

${ }^{4}$ Bucharest Emergency Hospital, Calea Floreasca, no. 8, 014461, Bucharest, Romania e-mail: ioancristescu@yahoo.com

Corresponding author:

CORINA SPOREA

e-mail: corina.sporea@gmail.com 


\section{Computational modelling of the heat transfer through two-layer woven structure ensembles}

DOI: $10.35530 / I T .071 .03 .1653$

\section{ABSTRACT - REZUMAT}

\section{Computational modelling of the heat transfer through two-layer woven structure ensembles}

The purpose of the present study was to investigate the heat transfer through a system of two consecutive textile layers with woven macrostructures by numerical simulation, using FLUENT CFD software package. A novel approach for modelling of the textile structure was applied, based on jet systems. The heat transfer through the systems of layers was studied for indoor conditions, simulating skin and indoor air temperature, as well as the effect of the convective cross flow around the human body. The results of the study showed that the heat transfer through a system of two layers is strongly influenced by the porosity and thickness of the fabrics, as well as their arrangement in the systems as an insulating barrier between the body and the environment.

Keywords: systems of layers, woven textiles, jet system, CFD, FLUENT

Modelarea computațională a transferului de căldură prin ansambluri din două straturi de structuri țesute

Scopul prezentului studiu a fost investigarea transferului de căldură printr-un sistem format din două straturi textile consecutive cu macrostructuri țesute prin simulare numerică, folosind pachetul software FLUENT CFD. A fost aplicată o nouă abordare pentru modelarea structurii textile, bazată pe sisteme cu jet. Transferul de căldură prin sistemele de straturi a fost studiat pentru condiții interioare, simulând temperatura pielii și a aerului din interior, precum și influența fluxului transversal de căldură prin convecție în jurul corpului uman. Rezultatele studiului au arătat că transferul de căldură printr-un sistem format din două straturi este puternic influențat de porozitatea și grosimea țesăturilor, precum și de dispunerea acestora în sistem ca o barieră izolatoare între corp și mediu.

Cuvinte-cheie: sisteme de straturi, materiale textile țesute, sistem jet, CFD, FLUENT

\section{INTRODUCTION}

The thermophysiological comfort of a clothed body is a very complex problem, since clothing is an integral part of the heat exchange between the human and the environment. Henry [1] developed one of the first theories on the heat transfer through a textile barrier, taking into account the cumulative effects of the layers. A model with both convective and diffusive mechanisms of heat transfer through clothing was presented by Ogniewicz et al. [2]. Farnworth [3] proposed a relatively simple dynamic model, which included heat transfer by radiation and thermal conductivity, as well as diffusion transfer of moisture, accounting the effect of the fabric surface. Detailed dynamic modelling was performed later by Fan et al. [4]. Mathematical model for the transfer of heat and moisture through different samples of textiles was presented by Wissler et al. [5]. Dynamic model of the characteristics of heat and vapour transfer was introduced by Li et al. [6], following the double-layer model of the human thermoregulation [7]. A very detailed model with 40 segments of the human skin and a textile layer on it was developed by De Dear et al. [8]. Thereafter models of human thermoregulation were presented by $\mathrm{Xu}$ and Fiala et al. [9-10], where both the heat and vapour transfer through textile layers and the effect of absorption by the textile layers were included.

The consecutive layers of fabrics affect the thermal insulation of the clothing and the thermophysiological comfort, including the comfort of bedridden people [11], as the system of layers has different characteristics from the compound single layers. The main reasons for that are the change in the porosity of the single layers and the appearance of an air layer. The porosity of the system of layers cannot be calculated, as it is done in the case of single layers; the thickness of the air layer between two textile layers is also unknown. Therefore, it is difficult to estimate quantitatively how the porosity of the system has changed, on the first place, and how the transfer of heat in through-thickness direction of the system is affected, on the second. Though the problem of heat transfer through a system of textile layers has been investigated experimentally, our literature survey has shown that the simulation of heat transfer through two consecutive layers of textiles has not been studied numerically, using the possibilities of the Computational Fluid Dynamics (CFD). Therefore, the aim of the present study was to use a method for simulation of the 
structure of woven fabrics, which has been verified and applied for simulation of heat transfer through single layer woven fabrics [12]. The simulation allowed making an analysis of the effect of the fabrics' characteristics and the arrangement of the layers in the system on the heat transfer process in through-thickness direction of the textiles.

\section{MATERIALS AND METHODS}

\section{Mathematical model}

FLUENT 6.3 general purpose CFD software package was used to perform the numerical simulations. The mathematical model was based on the Reynolds averaged Navier-Stokes (RANS) partial differential equations and the continuity equation. The energy equation, implemented in FLUENT, was included to simulate the heat transfer:

$$
\begin{gathered}
\frac{\partial}{\partial t}(\rho E)+\nabla[\vec{v}(\rho E+p)]= \\
=\nabla\left[k_{\text {eff }} \nabla T-\sum_{j} h_{j} \vec{J}_{j}+\left(\overline{\bar{\tau}}_{\text {eff }} \vec{v}\right)\right]+S_{h}
\end{gathered}
$$

where $\rho$ is the density of the fluid $\left(\mathrm{kg} / \mathrm{m}^{3}\right), E-$ the energy, $\vec{v}$ - the velocity vector, $p-$ the pressure $(\mathrm{Pa})$, $T$ - the temperature $(\mathrm{K}), k_{\text {eff }}$ - the effective conductivity, $h_{j}$ - the sensible enthalpy, $\vec{J}_{j}$ - the diffusion flux of species $j, \overline{\bar{\tau}}_{\text {eff }}$ - the effective viscous stress tensor, $S_{h}$ - a term for the heat transfer of chemical reactions and any other heat sources defined.

The effective conductivity $k_{\text {eff }}$ was defined as:

$$
k_{\text {eff }}=k+k_{t}
$$

where $k$ is the thermal conductivity of the material and $k_{t}$ - the turbulent thermal conductivity.

To solve the closure problem, $k-\varepsilon$ turbulence model was applied, together with the SIMPLE algorithm and a second-order upwind difference scheme.

\section{Fabrics data}

Five samples of $100 \%$ cotton woven fabrics with different characteristics were selected to create systems of two layers. Table 1 summarizes the fabrics data: mass per unit area, warp and weft densities, linear density of the yarns used, thickness, porosity, and mean pore area. The porosity $V_{s}, \%$ was calculated, following the expression:

$$
V_{s}=100-\left(E_{w a}+E_{w f}-0.01 E_{w a} E_{w f}\right)
$$

where $E_{w a}(\%)$ and $E_{w f}(\%)$ are both warp and weft cover factors, calculated via the samples' warp $P_{\text {wa }}$ (ends/dm) and weft density $P_{w f}$ (picks/dm), the linear density of the warp $T t_{w a}$ (tex) and weft threads $T t_{w f}$ (tex), respectively:

$$
E_{w a}=k_{f} P_{w a} \sqrt{\frac{T t_{w a}}{1000}} \text { and } E_{w f}=k_{f} P_{w f} \sqrt{\frac{T t_{w a}}{1000}}
$$

where $k_{f}$ is a coefficient that depends on the material. It is noteworthy that the five selected samples covered a range of fabric weight from $89 \mathrm{~g} / \mathrm{m}^{2}$ to 202 $\mathrm{g} / \mathrm{m}^{2}$, thickness from $0.39 \mathrm{~mm}$ to $0.71 \mathrm{~mm}$ and areal porosity of $51.6 \%$ to $8.9 \%$. The mean pore area was measured experimentally (100 measurements per sample) with a microscope Optika DM-15 with a builtin digital camera, following the procedure in [13].

\section{Simulated cases and boundary conditions}

The geometry of each woven sample was built on the basis of a transformation method, described and verified in [19]. Each pore of the woven macrostructure was considered as an opening of a jet; thus the plane of the sample was presented as an in-corridor ordered jet system that consisted of a set of $3 \times 3$ jets (figure 1). According to the jet-system theory [14], every central jet is representative for the whole system, as the surrounding eight jets play the role of boundary conditions for the central jet. The geometry of each sample was built with FLUENT's GAMBIT pre-processor. A pipe-like domain was used for the simulation: the first sample (with thickness of $x_{1}$ ) was built $3 \mathrm{~mm}$ after the domain inlet and $8 \mathrm{~mm}$ before the domain outlet. The second sample (with thickness of $\mathrm{x}_{2}$ ) was immersed at a distance of $1 \mathrm{~mm}$ after the first sample.

Due to the different size of the samples (thickness of the yarns and size of the pores) the cross section of

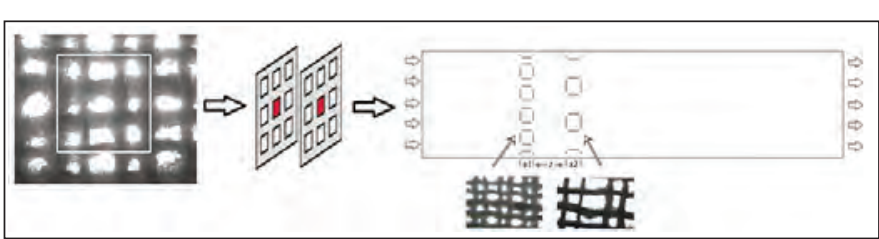

\begin{tabular}{|c|c|c|c|c|c|c|c|c|}
\hline $\begin{array}{c}\text { Sample } \\
\text { code }\end{array}$ & $\begin{array}{c}\text { Mass per } \\
\text { unit area } \\
\left(\mathrm{g} / \mathrm{m}^{2}\right)\end{array}$ & $\begin{array}{c}\text { Warp } \\
\text { density } \\
\text { (ends/dm) }\end{array}$ & $\begin{array}{c}\text { Weft } \\
\text { density } \\
\text { (picks/dm) }\end{array}$ & $\begin{array}{c}\text { Linear } \\
\text { density warp } \\
\text { (tex) }\end{array}$ & $\begin{array}{l}\text { Linear } \\
\text { density weft } \\
\text { (tex) }\end{array}$ & $\begin{array}{l}\text { Thickness } \\
(\mathrm{mm})\end{array}$ & $\begin{array}{c}\text { Porosity } \\
\text { (\%) }\end{array}$ & $\begin{array}{l}\text { Mean pore } \\
\text { area } S_{m} \\
\left(\mathrm{~mm}^{2}\right)^{2}\end{array}$ \\
\hline$K$ & 89 & 176 & 124 & 28 & 28 & 0.45 & 51.6 & 0.255 \\
\hline $\mathrm{P}$ & 133 & 284 & 294 & 20 & 20 & 0.39 & 29.1 & 0.038 \\
\hline$Y$ & 157 & 234 & 254 & 30 & 30 & 0.47 & 23.3 & 0.031 \\
\hline$S$ & 184 & 383 & 338 & 30 & 30 & 0.68 & 13.5 & 0.023 \\
\hline $\mathrm{R}$ & 202 & 386 & 226 & 30 & 30 & 0.71 & 8.9 & 0.014 \\
\hline
\end{tabular}

Fig. 1. Approximation method for building a system of two woven layers, based on the jet system theory

BASIC CHARACTERISTICS OF THE SIMULATED WOVEN MACROSTRUCTURES 
Table 2

\begin{tabular}{|c|c|c|c|c|c|}
\hline \multicolumn{5}{|c|}{ SIMULATED CASES WITH DATA FOR THE GRID } \\
\hline Case & $\begin{array}{c}\text { First } \\
\text { layer }\end{array}$ & $\begin{array}{c}\text { Second } \\
\text { layer }\end{array}$ & $\begin{array}{c}\text { Number } \\
\text { of cells }\end{array}$ & $\begin{array}{c}\text { Number } \\
\text { of faces }\end{array}$ & $\begin{array}{c}\text { Number } \\
\text { of nodes }\end{array}$ \\
\hline 1 & $\mathrm{P}$ & $\mathrm{K}$ & 152729 & 422556 & 124032 \\
\hline 2 & $\mathrm{~K}$ & $\mathrm{P}$ & 158761 & 440652 & 130064 \\
\hline 3 & $\mathrm{P}$ & $\mathrm{Y}$ & 76561 & 221373 & 70473 \\
\hline 4 & $\mathrm{Y}$ & $\mathrm{P}$ & 71689 & 206757 & 65601 \\
\hline 5 & $\mathrm{P}$ & $\mathrm{S}$ & 425966 & 1071864 & 219064 \\
\hline 6 & $\mathrm{P}$ & $\mathrm{R}$ & 1318777 & 3012569 & 531513 \\
\hline
\end{tabular}

the computational domain was built, applying the following requirements: (i) the axis of the central pore of the two consecutive layers of fabrics to be one and the same; (ii) the model of each woven macrostructure to involve at least $9(3 \times 3)$ pores (a tightly woven macrostructure involves more pores than the loosely woven macrostructure).

Six cases were simulated (table 2). Two types of grids were applied: a structured hexagonal grid, for meshing both the woven macrostructures and the numerical domain before and after the samples, and a hybrid grid in the space between the two samples. The data for the grid's cells, nodes and faces are shown in table 2. Obviously, Cases 5 and 6 had the most complex girds.

Temperature of $36^{\circ} \mathrm{C}$ was set at the inlet wall of the domain (hot wall) and $22^{\circ} \mathrm{C}$ at the inlet wall (cold wall), to simulate the heat transfer between the human skin and the temperature of the air in an air-conditioned indoor environment through the system of textiles. Symmetric boundary conditions were set on the three of the side walls of the domain. On the fourth wall a transversal convective flow (velocity $0.5 \mathrm{~m} / \mathrm{s}$ ) was set immediately after the second textile layer to simulate the natural convective flow around a human body.

\section{RESULTS AND DISCUSSIONS}

The effect of the characteristics of the layers

Figure 2 summarizes the temperature fields for Cases 1, 3, 5 and 6 . The thickness and the mass per unit area of the second layer is increasing (from figure 2, $a$ to $d$ ), thus increasing these parameters of the system. At the same time the porosity of the second layer is decreasing (from figure 2, a to $d$ ). The numerical results for the temperature field clearly show the influence of the characteristics of the layers on the heat transfer through the system. Due to the high porosity of Sample K $(51.6 \%)$, the heat transfer through the two layers is intensive (figure 2,a). The textile barrier has little resistance to the main flow at the outlet of the first layer (Sample P) and the main flow deforms the convective cross flow, creating conditions for intensive heat exchange. Compared to figure 2, $a$, in figure 2, $b$ the heat transfer through the system of two layers is impeded, due to the lower porosity of Sample $Y(23.3 \%)$. There is still influence of the main flow on the convective cross flow, but the

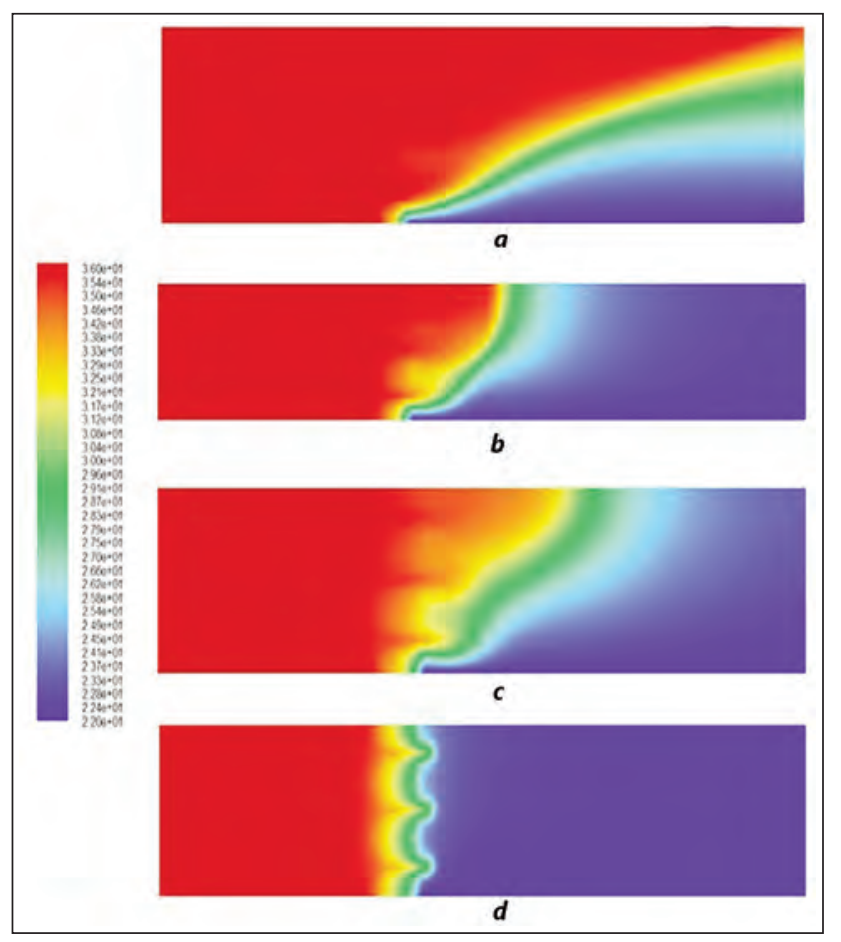

Fig. 2. Temperature field: $a$ - Case $1 ; b$ - Case 3; $c$ - Case 5; $d$ - Case 6

process is less intensive. The same is valid for figure 2, $c$ and figure 2, $d$ : the porosity of Samples $S$ and $R$ is very low, while their thickness increases, that leads to a continuous decrement of the heat transfer through the system, reaching suspension of the heat flow in figure $2, d$. The temperature drop is relatively low after the first layer (Sample P), but the second layer (Sample R), which porosity is $8.9 \%$, plays the role of best insulation layer: the heat on the left side of the domain is retained by the textile barrier (Case 6). Figure 3 shows the static pressure field for the same cases. Three main areas can be easily distinguished,

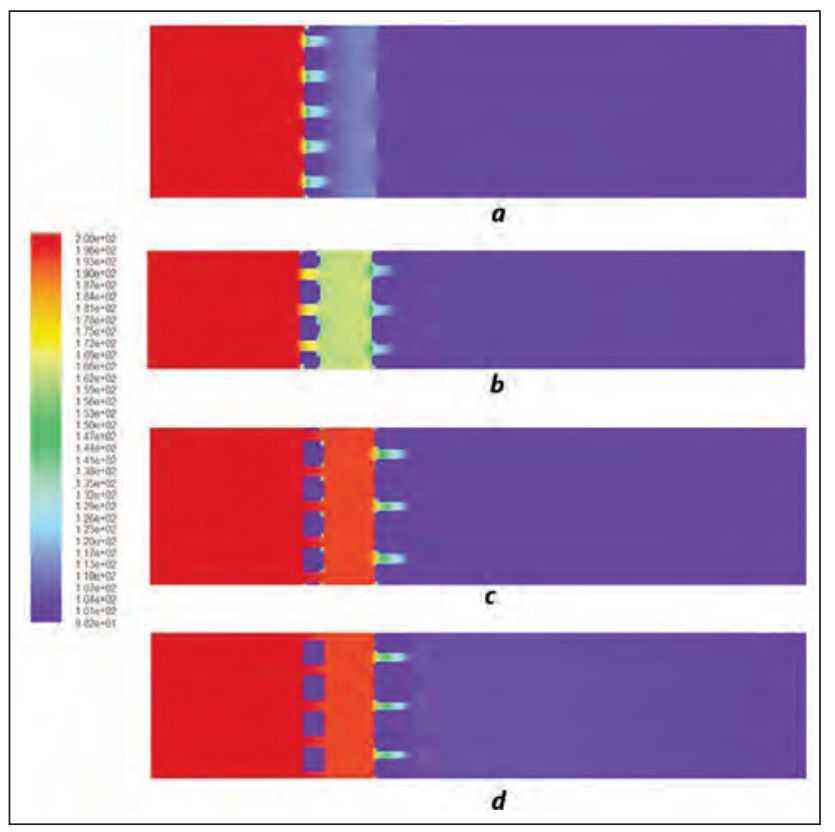

Fig. 3. Static pressure field: $a$ - Case $1 ; b$ - Case 3; $c$-Case $5 ; d$-Case 6 
which clearly depict the stages of pressure change: before the first sample, between the samples and after the second sample. The sudden change in the fluid pressure after the first sample is obvious for figures 3 , $a$ and $b$, as the first layer is of low porosity and pressure losses are consequently greater. The high porosity of the textile barrier accounts for the almost unchanged static pressure after the second layer (figure 3,a). This is the reason for the almost the same static pressure after the first layer in Case 5 (figure 3,c) and Case 6 (figure 3,d).

The effect of the arrangement of the layers in the system

Figure 4 presents the temperature field for Cases 1 and 2 and figure 5 - for Cases 3 and 4 . The differ- ence in each pair of cases is the arrangement of the two layers (table 2).

Figure 6, which shows the streamlines with the temperature map for Cases 1 and 2 is very appropriate to discuss the temperature fields in figures 4 and 5 . The numerical results show that the transfer of heat is more intensive when the more porous layer is on the second place (figures $4, a$ and $6, a$ ). The practical meaning is that in a clothing ensemble of two layers with different porosity, if the less porous layer is closer to the skin, the transfer of heat from the skin through the clothing to the environment will be higher. If the more porous layer is next to the skin and the less porous is the outside layer, the clothing will assure higher thermal insulation. Figure 6, a shows once again the intensive heat transfer in Case 1 that is barely influenced by the convective cross flow after

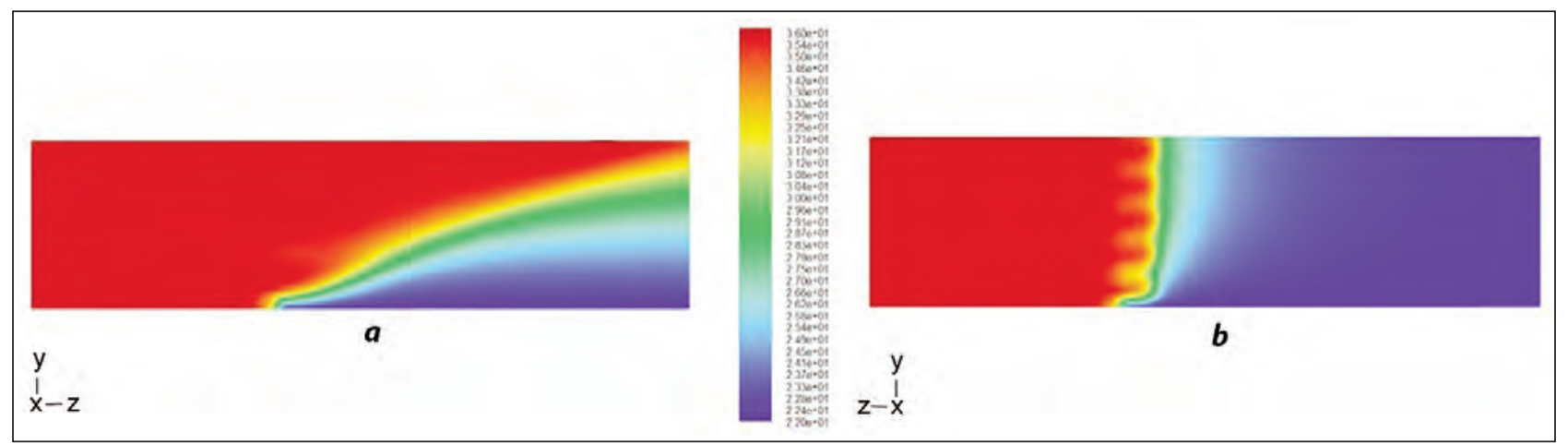

Fig. 4. Temperature field: $a$ - Case $1 ; b$ - Case 2

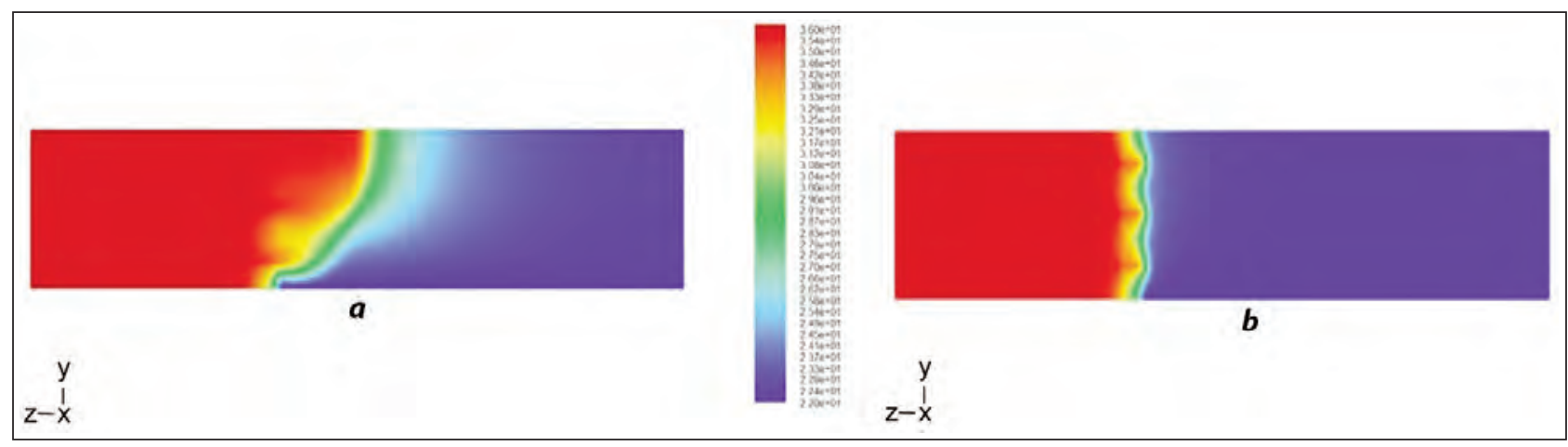

Fig. 5. Temperature field: $a$ - Case $3 ; b$ - Case 4

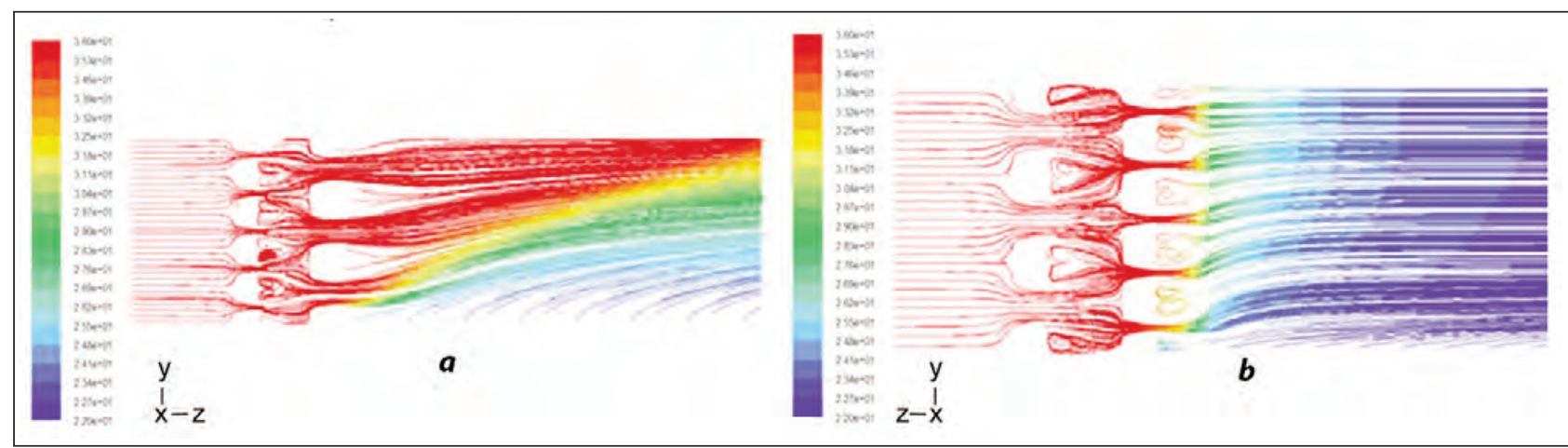

Fig. 6. Streamlines with temperature field: $a$ - Case $1 ; b$ - Case 2 
the textile. In Case 2 (figure 6, $b$ ), on the contrary, the temperature after the second layer is much lower and the convective cross-flow transports the heat in the vertical plane.

\section{CONCLUSIONS}

The process of heat transfer through various woven macrostructures and their combination were numerically simulated and analysed from the point of view of the interaction between the human body (skin) and the indoor environment. The effect of the porosity and thickness of the single layers on the heat transfer through the compound two-layer system was numerically proven and analysed. The effect of the arrangement of the layers in the systems on the heat transfer was also analysed with practical conclusions for design of clothing items.
The scientific contribution of this work lies in the way of simulation of the woven fabrics, based on jet-system theory and the novelties, related to the influence of the characteristics of the woven macrostructures and their arrangement in the two-layer system on the heat transfer. The results obtained allow to conclude that the proposed method for simulation could be applied for both further research on the topic (i.e. simulating more layers of different types) and designing clothing ensembles with desired insulating performance.

\section{ACHNOWLEDGEMENT}

The authors would like to thank the Research and Development Sector at the Technical University of Sofia for the financial support for the publishing of the present research.

\section{REFERENCES}

[1] Henry, P.S.H., Diffusion in absorbing media, In: Proceedings of the Royal Society of London A: Mathematical, Physical and Engineering Sciences, 1939, 171, 945, 215-241

[2] Ogniewicz, Y., Tien, C.L., Analysis of condensation in porous insulation, In: International Journal of Heat and Mass Transfer, 1981, 24, 3, 421-429

[3] Farnworth, B., A numerical model of the combined diffusion of heat and water vapor through clothing, In: Textile Research Journal, 1986, 56, 11, 653-665

[4] Fan, J., Cheng, X.Y., Heat and moisture transfer with sorption and phase change through clothing assemblies. Part I: Experimental investigation, In: Textile Research Journal, 2005, 75, 2, 99-105

[5] Wissler, E.H., Havenith, G., A simple theoretical model of heat and moisture transport in multi-layer garments in cool ambient air, In: European journal of applied physiology, 2009, 105, 5, 797-808

[6] Li, Y., Holcombe, B.V., Mathematical simulation of heat and moisture transfer in a human-clothing-environment system, In: Textile Research Journal, 1998, 68, 6, 389-397

[7] Gagge, A.P., An effective temperature scale based on a simple model of human physiological regulatory response, In: ASHRAE Transactions, 1971, 77, 2, 247-262

[8] De Dear, R.J., Arens, E., Hui, Z., Oguro, M., Convective and radiative heat transfer coefficients for individual human body segments, In: International Journal of Biometeorology, 1997, 40, 3, 141-156

[9] Xu, X., Werner, J., A Dynamic Model of the Humall/Clothing/Envirorllnent-System, In: Applied human science, $1987,16,2,61-75$

[10] Fiala, D., Lomas, K.J., Stohrer, M., A computer model of human thermoregulation for a wide range of environmental conditions: the passive system, In: Journal of Applied Physiology, 1999, 87, 5, 1957-1972

[11] Angelova, R.A., Textiles and human thermophysiological comfort in the indoor environment, Boca Raton: CRC Press, 2016

[12] Angelova, R.A., Kyosov, M., Stankov, P., Numerical investigation of the heat transfer through woven textiles by the jet system theory, In: The Journal of The Textile Institute, 2018, 1-10

[13] Angelova, R., Determination of the pore size of woven structures through image analysis, In: Open Engineering, 2012, 2, 1, 129-135

[14] Stankov, P., Three dimensional turbulent flows in heat and mass transfer processes, DSc Thesis, Technical University of Sofia, Bulgaria, 1998

\section{Authors:}

\section{ANGELOVA A.RADOSTINA ${ }^{1}$, MIROSLAV KYOSOV², PETER STANKOV²}

${ }^{1}$ Technical University of Sofia, Department of Textiles, 1000 Sofia, Bulgaria

2 Technical University of Sofia, Centre for Research and Design in Human Comfort, Energy and Environment (CERDECEN), 1000, Sofia, Bulgaria

e-mail: mircho@abv.bg, peter.stankov@abv.bg

Corresponding author:

ANGELOVA A. RADOSTINA

e-mail: joy_angels@abv.bg 


\title{
A new objective function for the assembly line balancing optimization in terms of workers' global competence
}

\author{
DOI: 10.35530/IT.071.04.1545
}

\section{ABSTRACT - REZUMAT}

\section{A new objective function for the assembly line balancing optimization in terms of workers' global competence}

This paper proposes an optimization model for the Assembly Line Balancing Problem (ALBP) in order to improve the work group choice in clothing industry. Traditionally, ALBP deals with several objectives like minimization of workstations number, minimization of cycle time, maximization of workload smoothness, and maximization of work relatedness...but neglect operators' performance. As the worker competence is crucial to both product quality and productivity, an approach is proposed to balance production line through optimal operators' assignment with the consideration of their skill levels. Based on two criteria, which are the Quality Index "QI" and the Activity "A", each worker was evaluated in each executed operation. From these individual criteria, global indicators of the work group selected were proposed. Applying the Weighted Sum Model (WSM) a more general indicator which is the global Competence Index "Cl " was presented. Using simple linear regression model, the global competence was modelled. Thereafter, the model was validated and justified. The resulting performance indicator allowed predicting the global competence level, comparing different balancing proposals and making an optimal choice. So, a new objective function to maximize can be used in $A L B P$ resolution in order to optimize the selected group capability.

Keywords: Assembly Line Balancing Problem, objective function, Weighed Sum Model, global competence index, simple linear regression model

\section{O nouă funcție obiectiv pentru optimizarea echilibrării liniei de asamblare corelată cu nivelul de competență globală al lucrătorilor}

Acest studiu propune un model de optimizare a problemei de echilibrare a liniei de asamblare (ALBP) pentru a îmbunătăți alegerea grupului de lucru din industria de îmbrăcăminte. În mod tradițional, ALBP tratează mai multe obiective precum minimizarea numărului de stații de lucru, minimizarea timpului de lucru, maximizarea volumului de muncă și maximizarea relației de muncă ... dar neglijează performanțele operatorilor. Întrucât competența lucrătorului este esențială atât pentru calitatea produsului, cât și pentru productivitate, se propune o abordare pentru a echilibra linia de producție prin atribuirea operatorilor optimi cu luarea în considerare a nivelului lor de competență. Pe baza a două criterii, care sunt indicele de calitate „QI” și activitatea „A”, fiecare lucrător a fost evaluat în fiecare operație executată. Din aceste criterii individuale, s-au propus indicatori globali ai grupului de lucru selectat. Folosind modelul sumei ponderate (WSM), a fost prezentat un indicator mai general, care este indicele global de competență " $\mathrm{Cl} g$ ". Folosind un model de regresie liniară simplă, a fost modelată competența globală. Ulterior, modelul a fost validat și justificat. Indicatorul de performanță rezultat a permis preconizarea nivelului de competență globală, compararea diferitelor propuneri de echilibrare și luarea unei decizii optime. Prin urmare, o nouă funcție obiectiv de maximizare poate fi utilizată în rezolvarea ALBP pentru a optimiza capacitatea grupului selectat.

Cuvinte-cheie: problema de echilibrare a liniei de asamblare, funcție obiectiv, model de sumă ponderată, indice de competență globală, model de regresie liniară simplă

\section{INTRODUCTION}

Textile industry is one of the world's numerous industries specially the clothing one [1]. In this sector, every day, managers and workers face globalization and subsequent changes in organizational directions and goals. The clothing production process is based on the sewing, a phase which contains an important number of operations. A sequence of workstations constitutes the sewing line. Every workstation involves one to several tasks assigned to workers according to their capability [1]. This is the assembly line phenomenon developed to meet market requirements in terms of product variability, production rates and costs, cycle times and quality levels. Assembly lines can organize production in three different ways: single model, multi-model and mixed-model assembly lines [2]. The design of a single model assembly is constructed for only one type of product. The mixed-model assembly produces different products at the same time and the multi-model produces a sequence of batches with intermediate setup operations [3-4].The big challenge is to assign tasks to 
workstations and so to workers as equally as possible. Unequal workload among workstations of a sewing line will lead to the increase of both works in process time and waiting time, indicating the increase of both production cycle time and cost [5]. In general, the choice of workers assignment, depending on the task sequence and duration, labour skill levels, the availability of means and the individual preferences of the decision makers, is a highly complex problem [6]. In practice, the decision making is based on past experiences, judgment and intuition which becomes rather difficult and cannot be guaranteed from one manager to another [7]. The human mind is also not capable of perceiving in all details many parameters at a time. Decision making is no more an art where the decision maker can apply mental models to find solution [8-9]. It is gradually becoming more and more scientific. In scientific decision making, mathematical models are applied to find solutions to organizational problems [10]. The decision problem of optimally balancing the assembly work among the workstations with respect to some objective is known as the Assembly Line Balancing Problem (ALBP) [11]. Since assembly line balancing is an NP-hard problem, some heuristic methods are still needed to solve large scale assembly line balancing problems [1]. For several years many research have been developed to solve ALBP. Because of the numerous simplifying assumptions underlying this basic problem, the field of research has traditionally focused on Simple Assembly Line Balancing Problem (SALBP) [12].

\section{The Simple Assembly Line Balancing Problems (SALBP)}

Baybars specified the assumptions underlying SALBP [13]:

(A-1): all input parameters are known with certainty;

(A-2): a task cannot be split among two or more stations;

(A-3): tasks cannot be processed in arbitrary sequences due to technological precedence requirements;

(A-4): all tasks must be processed;

(A-5): all stations under consideration are equipped and manned to process any one of the tasks;

(A-6): the task process times are independent of the station at which they are performed and of the preceding or following;

(A-7): any task can be processed at any station;

(A-8): the total line is considered to be serial with no feeder or parallel subassembly lines or any possible interaction of this type is ignored;

(A-9): the assembly system is assumed to be designed for a unique model of a single product.

Other versions of SALBP are summarized in the table 1.

SALBP-F: A Feasibility $(F)$ problem which is to establish whether or not a feasible line balance exists for a given combination of number of workstations $m$ and cycle time $c$.

\begin{tabular}{|c|c|c|}
\hline \multicolumn{3}{|c|}{ VERSIONS OF SALBP } \\
\hline \multirow{2}{*}{$\begin{array}{c}\text { Number of } \\
\text { workstations } \mathbf{m}\end{array}$} & \multicolumn{2}{|c|}{ Cycle time c } \\
\cline { 2 - 3 } & Given & Minimize \\
\hline Given & SALBP-F & SALBP-2 \\
\hline Minimize & SALBP-1 & SALBP-E \\
\hline
\end{tabular}

SALBP-1: In addition to (A-1)-(A-9), we have: (A-10): the cycle time $c$ is given and fixed. The goal is to minimize the number of workstations $m$.

SALBP-2: The same as SALBP-1 except that instead of $(A-10)$ we have: $(A-11)$ : the number of workstations is given and fixed. The goal is to minimize the cycle time or equivalently, to maximize the production rate. SALBP-E: It combines models SALBP-1 and SALBP-2. The goal is to maximize the assembly line balancing Efficiency $(E)$ by minimizing the number of workstations and cycle time [14].

\section{The General Assembly Line Balancing Problem (GALBP)}

The assumptions of SALBP are very restricting with respect to real-world assembly line systems [15]. Therefore, researchers have recently intensified their efforts to identify, formulate and solve more realistic problems. Any problem of the ALBP type having at least one extended hypothesis of the SALBP has been named in literature the General Assembly Line Balancing Problem (GALBP). The multi-model and mixed-model assembly lines are clear examples. The state-of-the-art articles on GALBP [11, 15-16] described the evolution of the hypotheses and approaches of the proposed resolution. Some authors [15] compared 64 papers related to SALBP and GALBP problems (publications during the period 1955-1985). About twenty years later, there are 146 works dealing only with GALBP type problems [11]. Different additional characteristics have been incorporated in GALBP to get closer to the industry reality. Even real case applications for ALBPs are relatively few in literatures [17]. Boysen et al. classified ALBPs and pointed out that there were less than $5 \%$ articles explicitly solving line balancing of real world assembly systems [18]. In 2006, authors surveyed different studies dealing with many additional characteristics such as cost functions, equipment selection, paralleling, U-shaped line layout, assignment restrictions and stochastic task times [11]. Other studies have worked on maximizing the workload smoothness, for a given number of workstations or maximizing the work relatedness by arranging the tasks in a workstation or even combining these last two objectives [19]. In spite of these efforts, which are referred, to as GALB, there seems to be a wide gap between the academic discussion and practical applications [20]. Conducted studies neglected significant factors affecting the decision making on assembly line balancing in labour intensive industries, such as labour skill levels [5]. The operator factors were rarely considered in solving the 
ALBP. It is widely ignored in real situations of labour intensive industry, such as apparel manufacturing. Even with the optimal task sequence employed, and minimized cycle time obtained, the production line still cannot be balanced in most cases. This is because of the efficiency variance among operators and uncertain efficiency of the same operator in different situations [21]. From a normative side, ISO 9001:2008 provides, for human resources management in Chapter 6.2, that the skills performing activities affecting the product conformity should be identified and that companies should implement adequate actions to meet these skills needs [22]. The workers evaluation and assignment system is an important problem that can significantly affect the future competitiveness and the performance of an organization [23]. In the apparel industry, despite the presence of certain workforce assessing methods, managers have expressed some reservations about these appreciation methods. They expressed their wish to determine objective indicators that would eliminate all subjectivity [24]. In 2014, the skill levels were defined simply by the number of machine types that an operator can perform [5]. For example, worker operating two machine types have a number of skill levels equals 2 . This study focuses on the development of a new objective function which can be used in a further work indented to solve GALBPs. The objective function targets the competence of the whole work group from individual competences. An objective assessment based on measurable criteria is used to judge operators' capability. The ALB optimization may formulate with the objective of maximizing the workers global competence. This optimization makes it possible to work with the best performing group. Thus, this work will serve to minimize defects, increase productivity and improve competitiveness.

\section{MATERIALS AND METHODS}

\section{The studied items}

This work was carried out in a company specialized in automotive textile products. This exporting compa- ny employs 25 persons with an annual production of $2,000,000$ pieces. It makes technical items (security nets, straps, bracelets, gearbox covers) for the automotive and transport industry to several brands (Mercedes Benz, Volkswagen, DAF). This type of items requires a high quality level. In fact, its usage attached to human security expects alertness on its manufacturing quality. This work was achieved in a production line making seat belts for the lower bunks of semitrailer truck cabins. Three seat belt models were used to build the database (figure 1).

\section{Performance indicators of individual skills}

In general, an operator is qualified both by work quality and production capacity. To express the work quality, a Quality Index “QI" (equation 1) was used. Based on Defects Ratio "DR" (equation 2) produced by each worker and a Defect Enhancer Coefficient "DEC" (equation 3) characterizing the weight of each defect, this criterion summarizes the quality level. For the production capacity, the operator Activity "A" (equation 4) may be an indicator [25]:

$$
Q I_{i}=1-\sum_{j}^{n} D E C_{j} \times D R_{j}
$$

where $n$ is the number of defect types.

$$
\begin{gathered}
D R(\%)=\frac{\text { Number of defects }}{\text { Number of controlled pieces }} \times 100 \\
D E C=1+\frac{\text { Defect cost }}{\text { Item cost price }} \\
A_{i}=\frac{\text { Productive time }}{\text { Attendance time }- \text { Time off standard }}
\end{gathered}
$$

\section{Global Performance indicators}

In clothing industry, operators are capable to perform from one to several operations. Therefore, many possible assignments can be envisaged. The resulting work differs from a group to another in terms of defects rate, rejected pieces rate, productivity etc. In practice, the choice is up to experts and in case of use computer software the objectives never target the workers' competence. Thus, to express the global

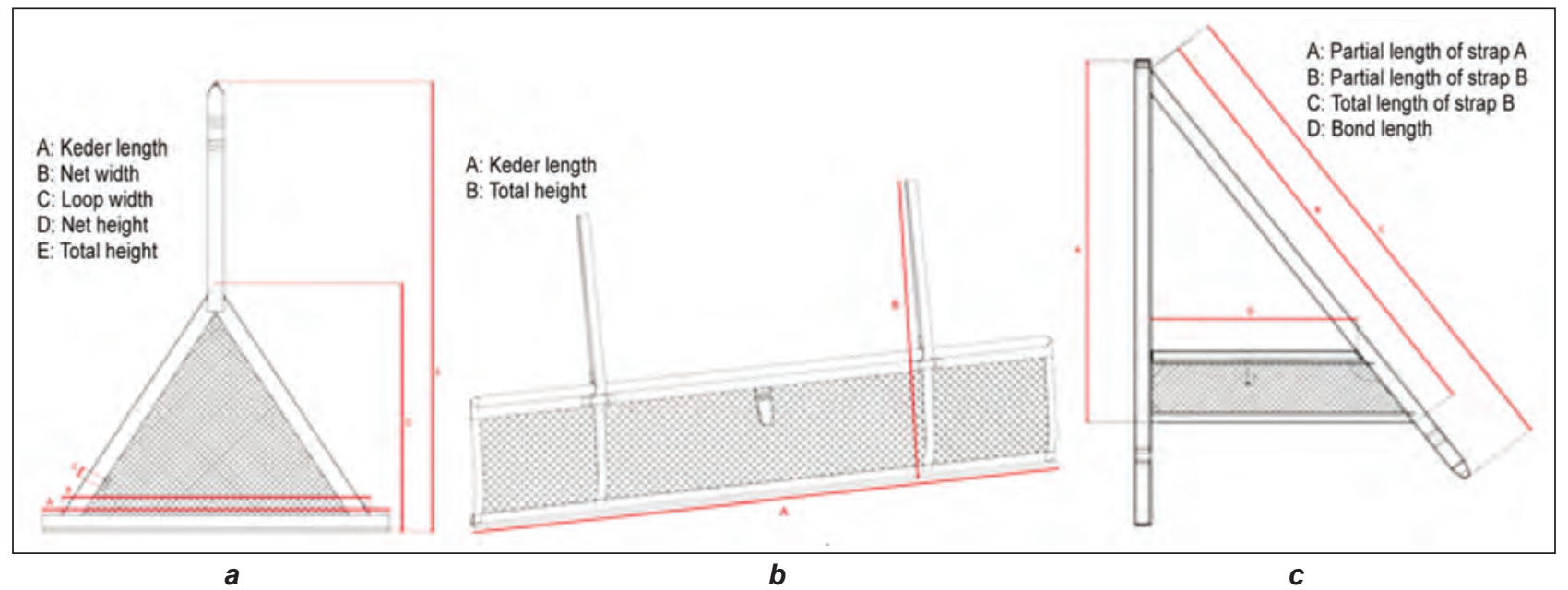

Fig. 1. Seat belt models: $a$ - sketch of model 102; $b$ - sketch of model 109; $c$ - sketch of model 111 
competence of the selected work group from the operators' individual skills performance, the following global indicators were proposed (equations 5, 6 and 7). Global Quality Index was calculated:

$$
Q I_{g}=1-\sum_{i}^{N} \sum_{j}^{n} D E C_{j} \times D R_{j}=1-\left(N-\sum_{i}^{N} Q I_{i}\right)
$$

where $N$ is the number of tasks (if a task is executed by more than one operator $N$ is equal to the operators number). This index expresses the quality level of the selected group since it sums the defects rate produced by all the workers weighted obviously by their DECs.

Global Activity was calculated:

$$
A_{g}=A_{i \text { (latest task })}
$$

The Activity of the worker performing the latest task reflects the group state. In fact, since it is the chain exit the latest workstation describes the produced quantity of the finished product. The latest worker reflects the global Activity even in case of supply disturbance. If the latest task is performed by more than one worker, the global Activity will be the weighted average of workers' Activities.

Global Competence Index was calculated:

$$
\begin{gathered}
C I_{g}=\alpha \times Q I_{g}+\beta \times A_{g}= \\
=\alpha \times\left(1-\sum_{i}^{N} \sum_{j}^{n} D E C_{j} \times D R_{j}\right)+\beta \times A_{i(\text { latest task })}= \\
=\alpha \times\left(1-\left(N-\sum_{i}^{N} Q I_{i}\right)+\beta \times A_{i(\text { latest task })}\right. \\
\alpha+\beta=1
\end{gathered}
$$

where $\alpha$ and $\beta$ are weighting coefficients respectively of $Q I_{g}$ and $A_{g}$.

A more generalized indicator called global Competence Index " $\mathrm{Cl}_{\mathrm{g}}$ " was developed thanks to a Multi-Criteria Decision Making (MCDM) method which is the Weighted Sum Model (WSM) [27-28]. This method summarized both the global Quality Index and the global Activity in a one indicator. It gave also the advantage of weighting the judgment criteria.

\section{Modelling the global competence}

All operators were tested in each operation of the 3 models which they were judged able to perform according to the competency matrices. The advantage in this company is that it works in large series, so, this test lasted for three months in order to assign the operators in different workstations. This allowed widening the study to have a concrete judgment. $Q I_{i}$ and $A_{i}$ which are the mean values of several tests constituted the database.

Afterwards, 5 possible combinations of ALB for each of the 3 selected models were implemented. Each ALB was implemented for a whole day of work. The production was organized for single model assembly line. All operators judged able, according to the competency matrix, to perform tasks were introduced. So, the workers number was given and fixed. A task can be shared by up to 3 operators and an operator can perform up to 3 tasks. ALB indicators like saturations, cycle times, and production rates were not optimized at this level since the main objective was to model the workers' global performance from the individual skills. This does not prevent that the assignments made were feasible and within logical limits discussed with the company to ensure that it could be practiced for our study.

For each proposed ALB and from the database already built, the couple $\left(Q I_{i T H}, A_{i T H}\right)$ was awarded for each operator in each executed task.

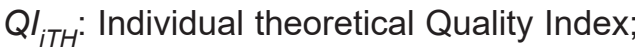

$A_{i T H}$ : Individual theoretical Activity.

Once the ALB is implemented, the couple $\left(Q I_{i E X}, A_{i E X}\right)$ was awarded for each operator from the resulting data of a day's work.

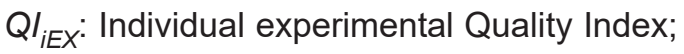

$A_{i E X}$ : Individual experimental Activity.

Global indicators of the whole work group ( $Q I_{g T H}$, $\left.Q I_{g E X}, A_{g T H}, A_{g E X}, C l_{g T H}, C I_{g E X}\right)$ were deduced for each ALB.

QI $_{g T H}$ : Global theoretical Quality Index;

$Q I_{g E X}$ : Global experimental Quality Index;

$A_{g T H}$ : Global theoretical Activity;

$A_{g E X}:$ Global experimental Activity;

$\mathrm{Cl}_{\text {gTH }}$ : Global theoretical Competence Index;

$\mathrm{Cl}_{\text {gEX }}$ : Global experimental Competence Index.

In this study, $Q I_{g}$ and $A_{g}$ were considered of equal weights, so $\alpha=\beta=0.5$.

Using a simple linear regression model, experimental global Competence Indices were expressed by theoretical ones.

\section{RESULTS AND DISCUSSIONS}

\section{Database building}

The database was constructed according to the selected performance indicators $\left(Q_{i}, A_{i}\right)$. For the 3 models each worker was tested in all tasks which can perform. The competency matrix of the model 102 is given bellow. This item was achieved in 8 operations and performed by 6 operators (table 2).

The two following tables detail only the operation "Execute cross box strap".

Table 3 shows the defects database of this operation. Based on defect database, it is clear that the defect "shift stitch in strap side" has the higher DEC. This was caused by the great loss mainly in repair and rechecking time compared to the other defect. Table 4 shows $Q I_{i T H}$ and $A_{i T H}$ for three operators judged capable to perform the operation "Execute cross box strap" according to the competency matrix.

Operators' Performance indicators for all the tasks are illustrated bellow in table 5 .

Similarly, the performance indicators of workers performing model 109 and 111 are given respectively in tables 6 and 7. Model 109 was achieved in 8 operations and performed by 7 operators and model 111 was achieved in 12 operations and performed by 6 operators. 


\begin{tabular}{|c|c|c|c|c|c|c|c|c|}
\hline \multicolumn{9}{|c|}{ COMPETENCY MATRIX (MODEL 102) } \\
\hline \multirow{2}{*}{ No. } & \multirow{2}{*}{ Operation } & \multirow{2}{*}{ Machine } & \multicolumn{6}{|c|}{ Operator } \\
\hline & & & OP1 & OP2 & OP3 & OP4 & OP5 & OP6 \\
\hline 1 & Cut keder & Automatic blade & $\mathrm{x}$ & & $\mathrm{X}$ & $\mathrm{X}$ & & \\
\hline 2 & Fixing the strap on $90 \mathrm{~mm}$ & 1-needle lockstitch machine (301) & $\mathrm{X}$ & & $\mathrm{x}$ & $\mathrm{X}$ & $\mathrm{X}$ & $\mathrm{X}$ \\
\hline 3 & Execute cross box strap & Automate & $\mathrm{X}$ & & & $\mathrm{X}$ & $\mathrm{X}$ & \\
\hline 4 & Apply band and net & 1-needle lockstitch machine (301) & $x$ & $\mathrm{x}$ & $\mathrm{X}$ & $\mathrm{X}$ & & \\
\hline 5 & Cut band ends & Hot cutter & $\mathrm{X}$ & & $\mathrm{X}$ & $\mathrm{X}$ & & \\
\hline 6 & Assemble keder and net & 2-needles lockstitch machine (301) & $\mathrm{X}$ & & $\mathrm{X}$ & $\mathrm{X}$ & & \\
\hline 7 & Execute safety seams & Automate & & & $\mathrm{X}$ & $\mathrm{X}$ & & $x$ \\
\hline 8 & Assemble strap and net & Automate & & & $\mathrm{X}$ & $\mathrm{X}$ & & \\
\hline
\end{tabular}

Table 3

\begin{tabular}{|l|l|l|l|l|l|l|l|l|}
\hline \multicolumn{7}{|c|}{ DEFECTS DATABASE OF THE OPERATION “EXECUTE CROSS BOX STRAP” } \\
\hline \multirow{2}{*}{ Operation } & $\begin{array}{c}\text { Defect } \\
\text { type }\end{array}$ & \multicolumn{1}{|c|}{$\begin{array}{c}\text { Defect repair } \\
\text { method }\end{array}$} & $\begin{array}{c}\text { Defect } \\
\text { repair } \\
\text { material }\end{array}$ & $\begin{array}{c}\text { Repair } \\
\text { material } \\
\text { cost }(\boldsymbol{\epsilon})\end{array}$ & $\begin{array}{c}\text { Defect } \\
\text { repair and } \\
\text { rechecking } \\
\text { time (S) }\end{array}$ & $\begin{array}{c}\text { Repair } \\
\text { time cost } \\
(\boldsymbol{\epsilon})\end{array}$ & $\begin{array}{c}\text { Defect } \\
\text { cost }(\boldsymbol{\epsilon})\end{array}$ & DEC \\
\hline \multirow{2}{*}{$\begin{array}{l}\text { Execute } \\
\text { cross box } \\
\text { strap }\end{array}$} & $\begin{array}{l}\text { Shift stitch in } \\
\text { elastic side }\end{array}$ & $\begin{array}{l}\text { Unthread the elastic } \\
\text { side and redo }\end{array}$ & Thread & 0.004 & 112.82 & 0.150 & 0.194 & 1.050 \\
\cline { 2 - 10 } & $\begin{array}{l}\text { Shift stitch in } \\
\text { strap side }\end{array}$ & $\begin{array}{l}\text { Unthread all the } \\
\text { stitch and redo }\end{array}$ & Thread & 0.009 & 287.82 & 0.384 & 0.433 & 1.111 \\
\hline
\end{tabular}

Table 4

\begin{tabular}{|c|c|c|c|c|c|c|c|c|}
\hline \multicolumn{9}{|c|}{$\begin{array}{l}\text { PERFORMANCE INDICATORS OF OPERATORS EXECUTING THE OPERATION } \\
\text { "EXECUTE CROSS BOX STRAP" }\end{array}$} \\
\hline \multirow[b]{2}{*}{ Operation } & \multirow[b]{2}{*}{ Operator } & \multirow[b]{2}{*}{$\begin{array}{l}\text { Number of } \\
\text { controlled } \\
\text { pieces }\end{array}$} & \multicolumn{2}{|c|}{ Number of defects } & \multicolumn{2}{|c|}{ DEC } & \multirow[b]{2}{*}{$\mathrm{QI}_{\mathrm{iTH}}$} & \multirow[b]{2}{*}{$\mathbf{A}_{\mathrm{iTH}}$} \\
\hline & & & $\begin{array}{l}\text { Skipped stitch } \\
\text { or Balloon } \\
\text { stitch }\end{array}$ & $\begin{array}{l}\text { Backstitch } \\
\text { missing }\end{array}$ & $\begin{array}{c}\text { Shift stitch } \\
\text { in elastic } \\
\text { side }\end{array}$ & $\begin{array}{l}\text { Shift stitch } \\
\text { in strap } \\
\text { side }\end{array}$ & & \\
\hline \multirow{3}{*}{$\begin{array}{l}\text { Execute } \\
\text { cross box } \\
\text { strap }\end{array}$} & OP1 & 840 & 12 & 0 & \multirow{3}{*}{1.050} & \multirow{3}{*}{1.111} & 0.859 & 0.653 \\
\hline & OP4 & 770 & 22 & 44 & & & 0.907 & 0.972 \\
\hline & OP5 & 840 & 18 & 90 & & & 0.985 & 0.972 \\
\hline
\end{tabular}

\begin{tabular}{|c|c|c|c|c|c|c|c|c|c|c|c|c|c|}
\hline \multicolumn{14}{|c|}{ OPERATORS' PERFORMANCE INDICATORS FOR MODEL 102} \\
\hline \multirow{3}{*}{ No. } & \multirow{3}{*}{ Operation } & \multicolumn{12}{|c|}{ Operator } \\
\hline & & \multicolumn{2}{|c|}{ OP1 } & \multicolumn{2}{|c|}{ OP2 } & \multicolumn{2}{|c|}{ OP3 } & \multicolumn{2}{|c|}{ OP4 } & \multicolumn{2}{|c|}{ OP5 } & \multicolumn{2}{|c|}{ OP6 } \\
\hline & & $\mathbf{Q I}_{\mathrm{iTH}}$ & $\mathbf{A}_{\mathrm{iTH}}$ & $\mathbf{Q I}_{\mathrm{iTH}}$ & $A_{\text {iTH }}$ & $\mathbf{Q I}_{\mathrm{iTH}}$ & $\mathbf{A}_{\mathrm{iTH}}$ & $\mathbf{Q I}_{\mathrm{iTH}}$ & $A_{\text {iTH }}$ & $\mathbf{Q I}_{\mathrm{iTH}}$ & $A_{\text {iTH }}$ & $\mathbf{Q I}_{\mathrm{iTH}}$ & $A_{\text {iTH }}$ \\
\hline 1 & Cut keder & 0.986 & 0.758 & & & 0.828 & 0.692 & 0.833 & 0.667 & & & & \\
\hline 2 & Fix the strap on $90 \mathrm{~mm}$ & 0.913 & 0.767 & & & 0.993 & 0.833 & 0.930 & 0.800 & 0.870 & 1.000 & 1.000 & 0.767 \\
\hline 3 & Execute cross box strap & 0.859 & 0.653 & & & & & 0.907 & 0.972 & 0.985 & 0.972 & & \\
\hline 4 & Apply band and net & 0.803 & 0.583 & 0.993 & 0.950 & 0.964 & 0.950 & 0.838 & 0.950 & & & & \\
\hline 5 & Cut band ends & 0.804 & 0.972 & & & 0.655 & 0.583 & 0.641 & 0.583 & & & & \\
\hline 6 & Assemble keder and net & 0.926 & 0.875 & & & 0.897 & 0.750 & 0.955 & 0.597 & & & & \\
\hline 7 & Execute safety seams & & & & & 0.998 & 0.889 & 1.000 & 0.778 & & & 0.979 & 1.000 \\
\hline 8 & Assemble strap and net & & & & & 0.982 & 0.857 & 0.886 & 1.000 & & & & \\
\hline
\end{tabular}




\begin{tabular}{|c|c|c|c|c|c|c|c|c|c|c|c|c|c|c|}
\hline \multicolumn{15}{|c|}{ OPERATORS' PERFORMANCE INDICATORS FOR MODEL 109} \\
\hline \multirow{3}{*}{ Operation } & \multicolumn{14}{|c|}{ Operator } \\
\hline & \multicolumn{2}{|c|}{ OP2 } & \multicolumn{2}{|c|}{ OP4 } & \multicolumn{2}{|c|}{ OP6 } & \multicolumn{2}{|c|}{ OP7 } & \multicolumn{2}{|c|}{ OP8 } & \multicolumn{2}{|c|}{ OP9 } & \multicolumn{2}{|c|}{ OP10 } \\
\hline & $\mathrm{QI}_{\mathrm{iTH}}$ & $A_{\mathrm{iTH}}$ & $\mathbf{Q I}_{\mathrm{iTH}}$ & $\mathbf{A}_{\mathrm{iTH}}$ & $\mathbf{Q I}_{\mathrm{iTH}}$ & $A_{i T H}$ & $\mathbf{Q I}_{\mathrm{iTH}}$ & $A_{i T H}$ & $\mathbf{Q I}_{\mathrm{iTH}}$ & $A_{\text {iTH }}$ & $\mathbf{Q I}_{\mathrm{iTH}}$ & $\mathrm{A}_{\mathrm{iTH}}$ & $\mathbf{Q I}_{\mathrm{iTH}}$ & $A_{i T H}$ \\
\hline Cut keder & & & & & 0.991 & 0.778 & 0.994 & 0.944 & 0.986 & 0.778 & & & 0.989 & 0.778 \\
\hline $\begin{array}{l}\text { Cut and burn } \\
\text { elastic }\end{array}$ & & & & & 0.988 & 0.839 & 0.998 & 0.968 & 0.982 & 0.839 & & & & \\
\hline $\begin{array}{l}\text { Apply small band } \\
\text { and net }\end{array}$ & & & & & 0.999 & 1.000 & 0.998 & 1.000 & 0.996 & 1.000 & & & & \\
\hline $\begin{array}{l}\text { Apply elastic and } \\
\text { band }\end{array}$ & & & 0.979 & 1.364 & 0.967 & 1.000 & & & 0.982 & 1.000 & & & & \\
\hline $\begin{array}{l}\text { Apply band and } \\
\text { net (insert } \\
\text { caoutchou) }\end{array}$ & 0.952 & 0.550 & & & & & & & & & 0.960 & 0.750 & 0.973 & 0.850 \\
\hline $\begin{array}{l}\text { plate the strap on } \\
\text { net }\end{array}$ & & & 0.987 & 1.111 & & & 0.989 & 1.000 & 0.971 & 0.933 & 0.968 & 0.933 & & \\
\hline $\begin{array}{l}\text { Assemble keder } \\
\text { and net (insert } \\
\text { label) }\end{array}$ & & & & & & & & & 0.960 & 0.556 & & & 0.972 & 0.556 \\
\hline $\begin{array}{l}\text { Execute safety } \\
\text { seams on } 4 \text { sides }\end{array}$ & & & 0.990 & 1.000 & 0.986 & 1.000 & 0.983 & 1.000 & 0.980 & 0.917 & 0.991 & 0.917 & & \\
\hline
\end{tabular}

\begin{tabular}{|c|c|c|c|c|c|c|c|c|c|c|c|c|}
\hline \multicolumn{13}{|c|}{ OPERATORS' PERFORMANCE INDICATORS FOR MODEL 109} \\
\hline \multirow{3}{*}{ Operation } & \multicolumn{12}{|c|}{ Operator } \\
\hline & \multicolumn{2}{|c|}{ OP3 } & \multicolumn{2}{|c|}{ OP4 } & \multicolumn{2}{|c|}{ OP5 } & \multicolumn{2}{|c|}{ OP6 } & \multicolumn{2}{|c|}{ OP8 } & \multicolumn{2}{|c|}{ OP10 } \\
\hline & $\mathbf{Q I}_{\mathrm{iTH}}$ & $\mathrm{A}_{\mathrm{iTH}}$ & $\mathbf{Q I}_{\mathrm{iTH}}$ & $A_{\text {iTH }}$ & $\mathbf{Q I}_{\mathrm{iTH}}$ & $\mathrm{A}_{\mathrm{iTH}}$ & $\mathbf{Q I}_{\mathrm{iTH}}$ & $\mathrm{A}_{\mathrm{iTH}}$ & $\mathbf{Q I}_{\mathrm{iTH}}$ & $A_{\text {iTH }}$ & $\mathbf{Q I}_{\mathrm{iTH}}$ & $\mathrm{A}_{\mathrm{iTH}}$ \\
\hline Apply small band and net & & & 0.987 & 0.857 & & & 0.994 & 0.857 & 1.000 & 1.000 & 0.978 & 0.814 \\
\hline Apply band, sponge and net & & & 0.984 & 0.778 & & & 0.990 & 0.722 & 0.997 & 0.889 & 0.974 & 0.711 \\
\hline Fix strap B & & & 0.997 & 1.000 & 0.980 & 0.917 & 0.994 & 1.000 & & & & \\
\hline Execute butterfly design & & & 1.000 & 1.000 & 0.983 & 0.917 & 0.991 & 1.000 & & & & \\
\hline Apply elastic on strap A and B & & & 0.858 & 1.364 & & & 0.898 & 0.909 & & & & \\
\hline Cut band ends & & & 0.870 & 1.000 & 0.808 & 0.917 & 0.847 & 0.958 & 0.839 & 1.000 & & \\
\hline Mark strap A and B & & & 0.997 & 1.000 & & & 0.997 & 1.000 & 0.991 & 1.000 & & \\
\hline \begin{tabular}{|l|} 
Plate strap B on left side of the \\
net and fix Velcro B \\
\end{tabular} & & & 0.979 & 1.111 & 0.930 & 1.000 & & & & & & \\
\hline $\begin{array}{l}\text { Plate strap A on right side of the } \\
\text { net and fix Velcro A }\end{array}$ & & & 0.982 & 1.111 & 0.924 & 1.000 & & & & & & \\
\hline Mark the end of strap A and B & 0.985 & 1.000 & 0.994 & 1.000 & 0.967 & 1.000 & 0.997 & 1.000 & 0.988 & 1.000 & 0.982 & 1.000 \\
\hline Cut strap B ends & & & 0.997 & 0.944 & & & 0.997 & 1.000 & 1.000 & 1.000 & & \\
\hline $\begin{array}{l}\text { Assemble strap A and B and } \\
\text { insert label }\end{array}$ & 0.982 & 0.833 & & & & & 0.991 & 0.972 & 1.000 & 0.972 & & \\
\hline
\end{tabular}

\section{Global performance assessment}

An example of an ALB for the model 102 is proposed and detailed in table 8 . This item was achieved in 393 seconds including the time of peel, control and pack. Those tasks were added to the initial operations which became 11. The control Agent (CA) was also added to the selected group.

The saturation varies from $89.06 \%$ to $110.43 \%$ which were acceptable in our study.
The following table demonstrates the couple $\left(Q l_{i T H}\right.$, $A_{i T H}$ ) estimated for each worker assigned according to the ALB proposed above. These theoretical values were extracted from the database (table 9).

Theoretical global indicators of this ALB were deduced using the equations 5,6 and 7 .

$$
\begin{aligned}
Q I_{\text {gTH }}= & 1-(8-(0.986+0.993+0.985+0.985 \\
& +0.804+0.897+0.979+0.886)=0.523 \\
A_{\text {gTH }}= & 1.000 \\
C l_{\text {gTH }}= & 0.5 \times 0.523+0.5 \times 1.000=0.762
\end{aligned}
$$




\begin{tabular}{|c|c|c|c|c|c|c|c|c|c|}
\hline \multicolumn{10}{|c|}{ ALB FOR MODEL 102} \\
\hline \multirow{3}{*}{ No. } & \multirow{3}{*}{$\begin{array}{c}\text { ON } \\
\text { FB } \\
\text { Operation }\end{array}$} & \multirow{3}{*}{$\begin{array}{c}7 \\
56.14 \\
\text { Time (s) }\end{array}$} & \multirow{2}{*}{\multicolumn{7}{|c|}{ Operator }} \\
\hline & & & & & & & & & \\
\hline & & & OP1 & OP2 & OP3 & OP4 & OP5 & OP6 & CA \\
\hline 1 & Cut keder & 15 & 15 & & & & & & \\
\hline 2 & Fixing the strap on $90 \mathrm{~mm}$ & 12 & & & 12 & & & & \\
\hline 3 & Execute cross box strap & 50 & & & & & 50 & & \\
\hline 4 & Apply band and net & 60 & & 60 & & & & & \\
\hline 5 & Cut band ends & 20 & 20 & & & & & & \\
\hline 6 & Assemble keder and net & 50 & & & 50 & & & & \\
\hline 7 & Execute safety seams & 40 & & & & & & 40 & \\
\hline 8 & Peel and control (intermidiary) & 45 & & & & & & 15 & 30 \\
\hline 9 & Assemble strap and net & 51 & & & & 51 & & & \\
\hline 10 & Control (final) & 30 & & & & & & & 30 \\
\hline 11 & Pack & 20 & 20 & & & & & & \\
\hline & TT & 393 & & & & & & & \\
\hline & Workload (s) & & 55.00 & 60.00 & 62.00 & 51.00 & 50.00 & 55.00 & 60.00 \\
\hline & Saturation (\%) & & 97.96 & 106.87 & 110.43 & 90.84 & 89.06 & 97.96 & 106.87 \\
\hline
\end{tabular}

Note: ON - Operator Number, TT - Total time, FB - Fragmentation Base $\left(F B=\frac{T T}{\mathrm{ON}}\right)$.

Table 9

THEORETICAL OPERATORS' PERFORMANCE INDICATORS FOR THE PROPOSED ALB

\begin{tabular}{|c|l|c|c|c|}
\hline No. & \multicolumn{1}{|c|}{ Operation (task) } & Operator & $\mathbf{Q I}_{\mathrm{iTH}}$ & $\mathbf{A}_{\mathrm{iTH}}$ \\
\hline 1 & Cut keder & OP1 & 0.986 & 0.758 \\
\hline 2 & $\begin{array}{l}\text { Fixing the strap on } \\
90 \mathrm{~mm}\end{array}$ & OP3 & 0.993 & 0.833 \\
\hline 3 & $\begin{array}{l}\text { Execute cross box } \\
\text { strap }\end{array}$ & OP5 & 0.985 & 0.972 \\
\hline 4 & Apply band and net & OP2 & 0.993 & 0.950 \\
\hline 5 & Cut band ends & OP1 & 0.804 & 0.972 \\
\hline 6 & $\begin{array}{l}\text { Assemble keder and } \\
\text { net }\end{array}$ & OP3 & 0.897 & 0.750 \\
\hline 7 & Execute seams safety & OP6 & 0.979 & 1.000 \\
\hline 8 & $\begin{array}{l}\text { Assemble strap and } \\
\text { net }\end{array}$ & OP4 & 0.886 & 1.000 \\
\hline
\end{tabular}

The global competence resulting from this proposed ALB was estimated at 0.762 . Having a global performance indicator in terms of quality and productivity of a selected group is a great advantage. It remains to model this global competence in order to rely on the resulting data.

\section{Simple linear regression model}

For each model, 5 ALBs were implemented. For each ALB, $\mathrm{Cl}_{g T H}$ was estimated from the database already built and $\mathrm{Cl}_{g E X}$ was calculated after an entire day's work. A linear relationship between $\mathrm{Cl}_{g E X}$ and $\mathrm{Cl}_{g T H}$ was established. Taking the ALB detailed in the previous section, the assignments were practiced and at the end of the day the couple $\left(Q I_{i E X}, A_{i E X}\right)$ was obtained as follow.

Based also on the equations 5,6 and 7, experimental global indicators calculation gives the following values:

$$
\begin{aligned}
Q l_{g E X}= & 1-(8-(0.925+1.000+0.984+1.000+ \\
& +0.688+0.979+0.989+0.985)=0.549 \\
A_{g E X}= & 1.043 \\
C l_{g E X}= & 0.5 \times 0.549+0.5 \times 1.043=0.796
\end{aligned}
$$

By the same way, the calculations were done to get the global indicators for 4 other ALBs of the model 102 and for 5 ALBs of the models 109 and 111. Table 11 summarizes the statistical results for the 3 models. By presenting the experimental values as a function of the theoretical ones for $\mathrm{Cl}_{g}$ (figure 2), we conclude that the global competence is modelled since there is a high regression coefficient $\left(R^{2}=92 \%\right)$. 


\begin{tabular}{|c|c|c|c|c|c|c|c|}
\hline \multicolumn{8}{|c|}{ GLOBAL INDICATORS FOR THE 15 ALBS OF THE 3 MODELS } \\
\hline Model & ALB & $\mathrm{QI}_{\mathrm{gTH}}$ & $A_{\mathrm{gTH}}$ & $\mathrm{Cl}_{\mathrm{gTH}}$ & $\mathrm{QI}_{\mathrm{gEX}}$ & $A_{g E X}$ & $\mathrm{Cl}_{\mathrm{gEX}}$ \\
\hline \multirow{5}{*}{102} & 1 & 0.523 & 1.000 & 0.762 & 0.549 & 1.043 & 0.796 \\
\hline & 2 & 0.269 & 0.857 & 0.563 & 0.396 & 1.000 & 0.698 \\
\hline & 3 & 0.090 & 0.857 & 0.474 & 0.093 & 1.000 & 0.547 \\
\hline & 4 & -0.443 & 0.857 & 0.207 & -0.068 & 1.000 & 0.466 \\
\hline & 5 & -0.064 & 1.000 & 0.468 & 0.169 & 1.000 & 0.585 \\
\hline \multirow{5}{*}{109} & 1 & 0.770 & 0.917 & 0.844 & 0.714 & 0.933 & 0.824 \\
\hline & 2 & 0.748 & 0.958 & 0.853 & 0.708 & 0.970 & 0.839 \\
\hline & 3 & 0.749 & 1.000 & 0.875 & 0.708 & 1.000 & 0.854 \\
\hline & 4 & 0.788 & 0.917 & 0.853 & 0.738 & 0.967 & 0.853 \\
\hline & 5 & 0.732 & 0.917 & 0.825 & 0.645 & 0.950 & 0.798 \\
\hline \multirow{5}{*}{111} & 1 & 0.467 & 0.972 & 0.720 & 0.543 & 1.000 & 0.772 \\
\hline & 2 & 0.712 & 0.972 & 0.842 & 0.818 & 1.000 & 0.909 \\
\hline & 3 & 0.498 & 0.972 & 0.735 & 0.601 & 1.027 & 0.814 \\
\hline & 4 & 0.681 & 0.972 & 0.827 & 0.824 & 0.944 & 0.884 \\
\hline & 5 & 0.578 & 0.972 & 0.775 & 0.742 & 1.000 & 0.871 \\
\hline
\end{tabular}

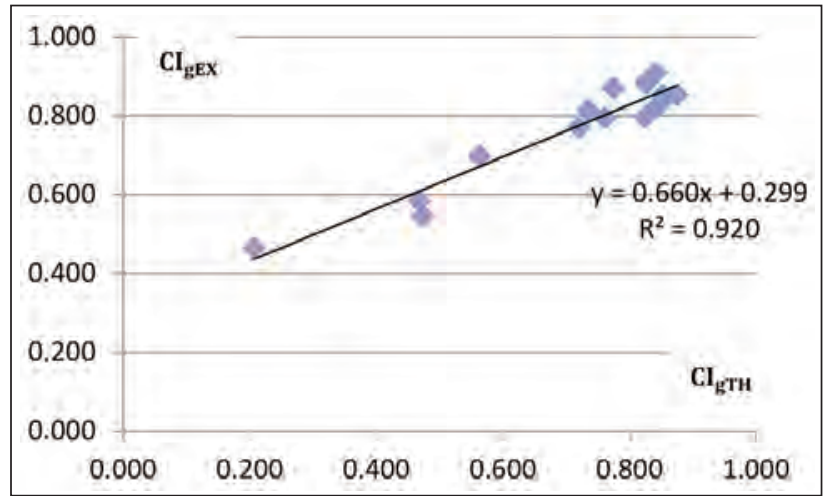

Fig. 2. $\mathrm{Cl}_{g E X}$ as a function of $\mathrm{Cl}_{g T H}$ for the $15 \mathrm{ALBs}$

According to the regression analysis made by the Minitab software, the regression equation is given in equation 8 as follow:

$$
C l_{g E X}=0.660 \mathrm{Cl}_{\text {gTH }}+0.299
$$

In the order to judge if the parameters' effect on the measured answer $\left(\mathrm{Cl}_{g E X}\right)$ is statistically significant, the variance analysis is an important test in this survey [28-29]. This test consists to calculate a statistical $F$ from the coefficients of the established model and then to compare it to statistical tables of Snedecor law [30]. Thereafter, from $F$, another $P$ statistic can be calculated. In fact:

If $P<1 \%$ : the parameter is highly significant;

If $1 \% \leq P \leq 5 \%$ : the parameter is significant;

If $P>5 \%$ : the parameter is not significant.

Table 12 reveals $P$-value given directly by the Minitab software.

Regarding table 12, P-value is null for $\mathrm{Cl}_{g E X}, \mathrm{Cl}_{g T H}$ and the constant. Then, we deduce that all the model parameters are highly significant.
Table 12

\begin{tabular}{|c|c|}
\hline \multicolumn{2}{|c|}{ RESULT OF ANALYSIS OF THE VARIANCE } \\
\hline Parameter & P-value \\
\hline ClgEX & 0.000 \\
\hline ClgTH & 0.000 \\
\hline Constant & 0.000 \\
\hline
\end{tabular}

\section{Model validation}

To validate this model, practical method was used. It consists in determining the average absolute relative error between the experimental values given by the linear model $\left(\widetilde{C l_{g E X}}\right)$ and those real; extracted after a day's work $\left(\mathrm{Cl}_{g E X}\right)$. The Mean Absolute Percentage Error (MAPE) is the average of errors; deviations in absolute value from the real experimental values (equation 9).This value represents a practical comparison indicator to judge whether the forecast model is good [31-32]:

$$
\text { Error(\%) }=\frac{C l_{g E X}-\widetilde{C l_{g E X}}}{C l_{g E X}} \times 100
$$

where $\widetilde{C I_{g E X}}$ is the Global experimental competence Index calculated from the linear model.

In order to implement it, 3 other ALBs are implemented; an ALB for each model. Table 13 recaps the main results.

The MAPE is equal to $2.5 \%$, which considered small. The statistical data confirmed that the theoretical and experimental values were close. So, the result of testing and predicting global competence for other ALBs using our model was well verified. Thus, the simple linear regression model was well justified and the findings showed the high significance of this study effectiveness. Considering that the regression 
AVERAGE ERRORS OF THE REGRESSION MODEL FOR 3 OTHER ALBS

\begin{tabular}{|c|c|c|c|c|}
\hline Model & $\mathbf{C I}_{\text {gTH }}$ & $\widetilde{\mathbf{C I}_{\text {gEX }}}$ & $\mathbf{C l}_{\text {gEX }}$ & Error \\
\hline 102 & 0.598 & 0.694 & 0.673 & $3.1 \%$ \\
\hline 109 & 0.884 & 0.883 & 0.866 & $1.9 \%$ \\
\hline 111 & 0.813 & 0.836 & 0.857 & $2.4 \%$ \\
\hline
\end{tabular}

coefficient was very high and the errors were low, we have ensured the validity of the obtained regression model. Therefore, the ALB optimization with the consideration of operators' performance is given by the following objective function (equation 10).

$$
\begin{gathered}
\text { Maximize } C I_{g}=\text { Maximize }\left(\alpha \times Q I_{g}+\beta \times A_{g}\right)= \\
=\text { Maximize }\left(\alpha \times\left(1-\sum_{i}^{N} \sum_{j}^{n} D E C_{j} \times D R_{j}\right)+\right. \\
\left.+\beta \times A_{i(\text { latest task })}\right)= \\
=\text { Maximize }\left(\alpha \times\left(1-\left(N-\sum_{j}^{N} Q I_{i}\right)\right)+\beta \times A_{i(\text { latest task })}\right)
\end{gathered}
$$

By summarizing both the quality level and the production capacity, the proposed objective function guarantees working with the most performing group.

\section{CONCLUSIONS}

This paper proposed an optimal work group choice solution for solving assembly line balancing problems with the consideration of the operators' skills. Using objective performance indicators, which are the Quality Index "QI," and the Activity " $A_{i}$ ", workers' skills were defined and measured. Through these individual indicators, a global Quality Index "QI " and a global Activity " $A_{g}$ " were proposed to express the performance of the whole selected work group. Weighed Sum Model "WSM" was used to combine those two indicators in only one which is the global Competence Index " $\mathrm{Cl}_{\mathrm{g}}$ ". This was modelled by a regression equation. Due to the regression coefficient and the $\mathrm{P}$-value, the global competence was considered modelled and significant.

By computing the mean absolute relative error of new implemented ALBs, the model was validated. Thanks to this work it became possible to evaluate and estimate the selected group performance level for any proposed balancing. Optimizing the balancing choice in terms of workers' skills is simply maximizing $\mathrm{Cl}_{\mathrm{g}}$. This study could be extended in several directions. An extension would be considering an objective function in heuristic method algorithms to solve ALBP. Moreover, this study deals with ALBP of single model and working with mixed-model or multi-model is also the extension of further researches.

\section{REFERENCES}

[1] Chen, J.C., Chen, C.C., Su, L.H., Wu, H.B., Sun, C.J., Assembly line balancing in garment industry, In: Expert Systems with Applications, 2012, 39, 10073-10081

[2] Eryuruk, S.H., Kalaoglu, F., Baskak, M., Assembly Line Balancing in a Clothing Company, In: Fibres \& Textiles in Eastern Europe, 2008, 16, 1, 66

[3] Scholl, A., Becker, C., State-of-The-Art Exact and Heuristic Solution Procedures for Simple Assembly Line Balancing, In: European Journal of Operational Research, 2004, 168, 666-693

[4] Adeppa, A., A Study on Basics of Assembly Line Balancing, In: International Journal on Emerging Technologies, (Special Issue on NCRIET-2015), 2015, 6, 2, 294-297

[5] Chen, J.C., Chen, C.C., Lin, Y.J., Lin, C.J., Chen, T.Y., Assembly Line Balancing Problem of Sewing Lines in Garment Industry, International Conference on Industrial Engineering and Operations Management Bali, Indonesia, 2014

[6] Afshari, A.R., Mojahed, M., Simple Additive Weighting Approach to Personnel Selection Problem, In: International Journal of Innovation and Technology Management, 2010, 1, 5, 511-515

[7] Agpak, K., Gökçen, H., Assembly line balancing: Two resource constrained cases, In: International Journal of Production Economics, 2005, 96, 129-140

[8] Jebali, N., Babay Dhouib, A., Ben Hassen, M., Modeling the overall seam quality of woven cotton fabri, In: International Journal of Applied Research on Textile, 2016, 4, 1, 47-61

[9] Souid, H., Sahnoun, M., Babay, A., Cheikhrouhou, M., A Generalized Model for Predicting Yarn Global Quality Index, In: The Open Textile Journal, 2012, 5, 6, 8-13

[10] Habiba U., Asghar, S., A survey on multi-criteria decision making approaches, International Conference on Emerging Technologies, Islamabad, Pakistan, 2009

[11] Becker, C., Scholl, A., A survey on problems and methods in generalized assembly line balancing, In: European Journal of Operational Research, 2006, 168, 694-715

[12] Boysen, N., Fliedner, M., Scholl, A., A classification of assembly line balancing problems, Arbeits- und Diskussionspapiere der Wirtschaftswissenschaftlichen Fakultät der Friedrich-Schiller-Universität Jena, 2006

[13] Baybars, I., A survey of exact algorithms for the simple assembly line balancing problem, In: Management Science, 1986, 32, 8

[14] Wei, N.C., Chao, I.M., A solution procedure for type E simple assembly line balancing problem, In: Computers \& Industrial Engineering, 2011, 61, 824-830

[15] Ghosh, S., Gagnon, R.J., A comprehensive literature review and analysis of the design, balancing and scheduling of assembly systems, In: International Journal of Production Research, 1989, 27, 4, 637-670 
[16] Rekiek, B., de Lit, P., Delchambre, A., Hybrid assembly line design and user's preferences, In: International Journal of Production Research, 2002, 40, 1095-1111

[17] Guschinskaya, O., Dolgui, A., Equilibrage de lignes de production, In: Journal Européen des Systèmes Automatisé, 2010, 44, 1079-1117

[18] Boysen, N., Fliedner, M., Scholl, A., Assembly line balancing: Which model to use when?, In: International Journal of Production Economics, 2008, 111, 509-528

[19] Boysen, N., Fliedner, M., Scholl, A., A classification of assembly line balancing problems, In: European Journal of Operational Research, 2007, 183, 674-693

[20] Scholl, A., Simple Assembly Line balancing-Heuristic Approaches, In: Journal of Heuristics, 1996, 2, 217-244

[21] Song, B.L., Wong, W.K., Fan, J.T., Chan., S.F., A recursive operator allocation approach for assembly line-balancing optimization problem with the consideration of operator efficiency, In: Computers \& Industrial Engineering, 2006, 51, 585-608

[22] ISO 9001, Chapter 6.2 human resources, 2008

[23] Golec, A., Kahya, E., A fuzzy model for competency-based employee evaluation and selection, In: Computers \& Industrial Engineering, 2007, 52, 143-161

[24] Savall, H., Zardet, V., Maîtriser les coûts et les performances cachées, 2003, 184-185

[25] Chourabi, Z., Khedher, F., Babay, A., Cheikhrouhou, M., Objective evaluation of workforce global performance by determining a new Competence Index, International Conference of Applied Research on Textile (CIRAT-7), Hammamet, Tunisia, 2016

[26] Afshari, A.R., Mojahed, M., Simple Additive Weighting Approach to Personnel Selection Problem, In: International Journal of Innovation and Technology Management, 2010, 5, 511-515

[27] Adriyendi, Multi-Attribute Decision Making Using Simple Additive Weighting and Weighted Product in Food Choice, In: I.J. Information Engineering and Electronic Business, 2015, 6, 8-14

[28] Miliken, G., Johnson, D., Analysis of Messy Data, In: Designed Experiments Van Reinhold, 1984, 1

[29] Nelson, P., A Comparison of Sample seizes for the analysis of means and analysis of variances, In: Journal of Quality Technology, 1983, 15, 33-39

[30] Olshen, R., The conditional level of the F-test, In: Journal of the American Association, 1973, 68, 692-698

[31] El-Ghezal, S., Sahnoun, M., Babay, A., Cheikhrouhou, M., Schacher, L., Adolphe, D., Predicting compression and surfaces properties of knits using fuzzy and neural networks techniques, In: International Journal of Clothing Science and Technology, 2011, 23, 5, 294-309

[32] Malek, S., Khedher, F., Jaouachi, B., Cheikhrouhou, M., Determination of a sewing quality index of denim fabrics, In: The Journal of The Textile Institute, 2017, 3, 2, 1-13

Authors:

ZOUHOUR CHOURABI, AMEL BABAY, FAOUZI KHEDHER, MORCHED CHEIKHROUHOU

Laboratory of Textile Engineering, University of Monastir, 5000, Tunisia

email: Igtex.secretaire@gmail.com

Corresponding author:

ZOUHOUR CHOURABI

email: zouhour.chourabi@gmail.com 
Industria Textila magazine is an international peerreviewed journal published by the National Research \& Development Institute for Textiles and Leather - Bucharest, in print editions

Aims and Scope: Industria Textila journal is addressed to university and research specialists, to companies active in the textiles and clothing sector and to the related sectors users of textile products with a technical purpose.

\section{Submission of Manuscripts}

Please read the guidelines below then visit the Journal's submission site manuscriptmanager.net/it or the button Submit manuscript to upload your manuscript. Please note that manuscripts not conforming to these guidelines may be returned.

Copyright Transfer Agreement must be signed and returned to our Editorial Office by mail, as soon as possible, after the preliminary acceptance of the manuscript. By signing this agreement, the authors warrant that the entire work is original and unpublished, it is submitted only to this Journal and all the text, data, Figures and Tables included in this work are original and unpublished, and have not been previously published or submitted elsewhere in any form. Please note that the reviewing process begins as soon as we receive this document. In the case when the paper has already been presented at a conference, it can be published in our journal only if it has not been published in a generally available conference materials; in such case, it is necessary to give an appropriate statement placed in Editorial Notes at the end of the article.

Manuscripts submitted are check against plagiarism with Anti-plagiarims System. Manuscripts of the following types are accepted:

Research Papers - An original research document which reports results of major value to the Textile Community

Book Reviews - A brief critical and unbiased evaluation of the current book, normally invited by the Editor.

Manuscripts shall be submitted in English in single-spaced typing, A4 paper, Arial, margins $2 \mathrm{~cm}$ on all sides, under electronic version in Word for Windows format.

The volume of the submitted papers shall not exceed 8 pages (including the bibliography, abstract and key words), typescript pages including tables, figures and photographs.

All articles received are reviewed by minimum two reviewers, renowned scientist and considered expert in the subject the article concerns, which is appointed by the editorial board. After the article has been accepted, with the completions and the modifications required by the reviewers or by the editorial staff, it will be published.
The submission of the above-mentioned papers is by all means the proof that the manuscript has not been published previously and is not currently under consideration for publication elsewhere in the country or abroad.

There may also be published papers that have been presented at national or international scientific events, which have not been published in volume, including the specification related to the respective event.

The articles assessed as inappropriate by the reviewer or by the editorial staff, concerning the subject matter or level, shall not be published.

The manuscript shall be headed by a concise title, which should represent in an exact, definite and complete way the paper content.

The manuscript shall also be headed by complete information about the author(s): titles, name and forename(s), the full name of their affiliation (university, institute, company), department, city and state, as well as the complete mailing address (street, number, postal code, city, country, e-mail, fax, telephone).

Tables and figures (diagrams, schemes, and photographs) shall be clear and color, where possible.

The photographs shall be sent in original format (their soft), or in JPEG or TIF format, having a resolution of at least 300 dpi.

All tables and figures shall have a title and shall be numbered with Arabic numerals, consecutively throughout the paper and referred by the number in the text.

Generally, symbols and abbreviations shall be used according to ISO 31: Specifications for quantities, units and symbols. SI units must be used, or at least given comprehensive explanations or their equivalent.

Cited references shall be listed at the end of the paper in order of quotation and contain: for a paper in a periodical - the initials and surname of the author(s), title of journal and of the article, year and number of issue, number of volume and page numbers; for a book - the initial and surname of the author(s), full name of the book, publisher, issue, place and year of publishing, and the pages cited; for patents - the initial and surname of the author(s), the title, the country, patent number and year. It is preferable not to use sites as references.

[1] Hong, Y., Bruniaux, P., Zhang, J., Liu, K., Dong, M., Chen, Y., Application of 3D-to-2D garment design for atypical morphology: a design case for physically disabled people with scoliosis, In: Industria Textila, 2018, 69, 1, 59-64, http://doi.org/10.35530/IT.069.01.1377

Authors are requested to send an abstract of the paper, preferably no longer than 250 words and a list of 5-6 key words (preferably simple, not compound words, in alphabetical order). 